UNIVERSIDADE DE SÃO PAULO

FACULDADE DE FILOSOFIA, LETRAS E CIÊNCIAS HUMANAS

DEPARTAMENTO DE LETRAS CLÁSSICAS E VERNÁCULAS

PROGRAMA DE PÓS-GRADUAÇÃO EM LITERATURA BRASILEIRA

JULIANA LUIZA DE MELO SCHMITT

Repercussões do macabro no romantismo brasileiro

(versão corrigida)

São Paulo

2014 
UNIVERSIDADE DE SÃO PAULO

FACULDADE DE FILOSOFIA, LETRAS E CIÊNCIAS HUMANAS

DEPARTAMENTO DE LETRAS CLÁSSICAS E VERNÁCULAS

PROGRAMA DE PÓS-GRADUAÇÃO EM LITERATURA BRASILEIRA

\title{
Repercussões do macabro no romantismo brasileiro
}

\author{
Juliana Luiza de Melo Schmitt
}

Tese apresentada ao Programa de PósGraduação em Literatura Brasileira do Departamento de Letras Clássicas e Vernáculas da Faculdade de Filosofia, Letras e Ciências Humanas da Universidade de São Paulo, para a obtenção do título de Doutora em Literatura Brasileira

Orientadora: Profa. Dra. Eliane Robert Moraes

São Paulo

2014 
Ao meu irmão, Henrique

Ao meu pai, Sérgio

- meus mortos mais queridos. 


\section{Agradecimentos}

À Coordenação de Aperfeiçoamento de Pessoal de Nível Superior (CAPES), pelo auxílio financeiro.

À professora Eliane Robert Moraes, pela confiança. 
“(...) quem entre nós poderia dizer que não tremeria diante da visão de um cadáver coberto de vermes?"

Georges Bataille, O erotismo. 


\section{Resumo}

A tese aborda o termo "macabro" desde suas origens na Baixa Idade Média, partindo dessa perspectiva histórica para interrogar as repercussões da literatura e da iconografia que lhe correspondem, sobretudo no século XIX. Neste, privilegia-se em particular o Romantismo, que se alimenta do imaginário medieval para criar uma estética em grande parte voltada a uma sensibilidade da morte. Em paralelo à análise de certas manifestações artísticas europeias, investiga-se a presença do macabro e suas configurações específicas em exemplares da poesia e da prosa do Brasil oitocentista. $\mathrm{O}$ poema A orgia dos duendes, de Bernardo Guimarães, tem lugar especial nessa investigação, por se revelar a mais completa e singular fantasia literária de dança macabra no país.

Palavras-chave: Macabro; Dança Macabra; Romantismo; Bernardo Guimarães. 


\begin{abstract}
This thesis, by historicizing the term "macabre" from its origins in the Late Middle Ages, seeks to understand the repercussions of both literature and iconography involving the macabre during the 19th Century, a time when the medieval imaginary was revived through Romanticism. The manifestations of this romantic sensibility as respects to death in the $19^{\text {th }}$ Century in Brazil are also investigated, in an attempt to analyze its influences in Brazilian poetry and prose. The poem A orgia dos duendes, by Bernardo Guimarães, is given special attention in this investigation, as it is deemed the most significant example of the Danse Macabre in Brazil.
\end{abstract}

Keywords: Macabre; Dance of Death; Romanticism; Bernardo Guimarães. 


\section{Sumário}

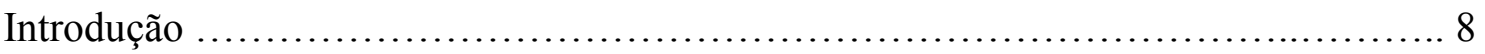

Capítulo 1

Origens do macabro

Capítulo 2

No rastro do macabro medieval

Capítulo 3

As danças macabras no século XIX

Capítulo 4

O Carnaval e a Morte

Capítulo 5

A macabra orgia da dança dos duendes

Considerações finais

Bibliografia 228

Índice de imagens 


\section{Introdução}

Em novembro de 1866, o diretor do Diário de São Paulo, Cândido Justiniano Silva, abriu um processo contra o semanário humorístico Cabrião. De acordo com o denunciante, o referido periódico havia ofendido a moral pública em uma ilustração de seu sexto número (de 4/11 daquele ano), assinada por Angelo Agostini, um de seus proprietários. O desenho representava uma farra entre vivos e mortos no cemitério da Consolação. Na cena, os convivas bebem animadamente, conversam, dançam, fumam e passeiam, entre as lápides. Um pequeno esqueleto, caminhando em primeiro plano, sugere até mesmo a participação de uma criança na ruidosa pândega. (figura 1)

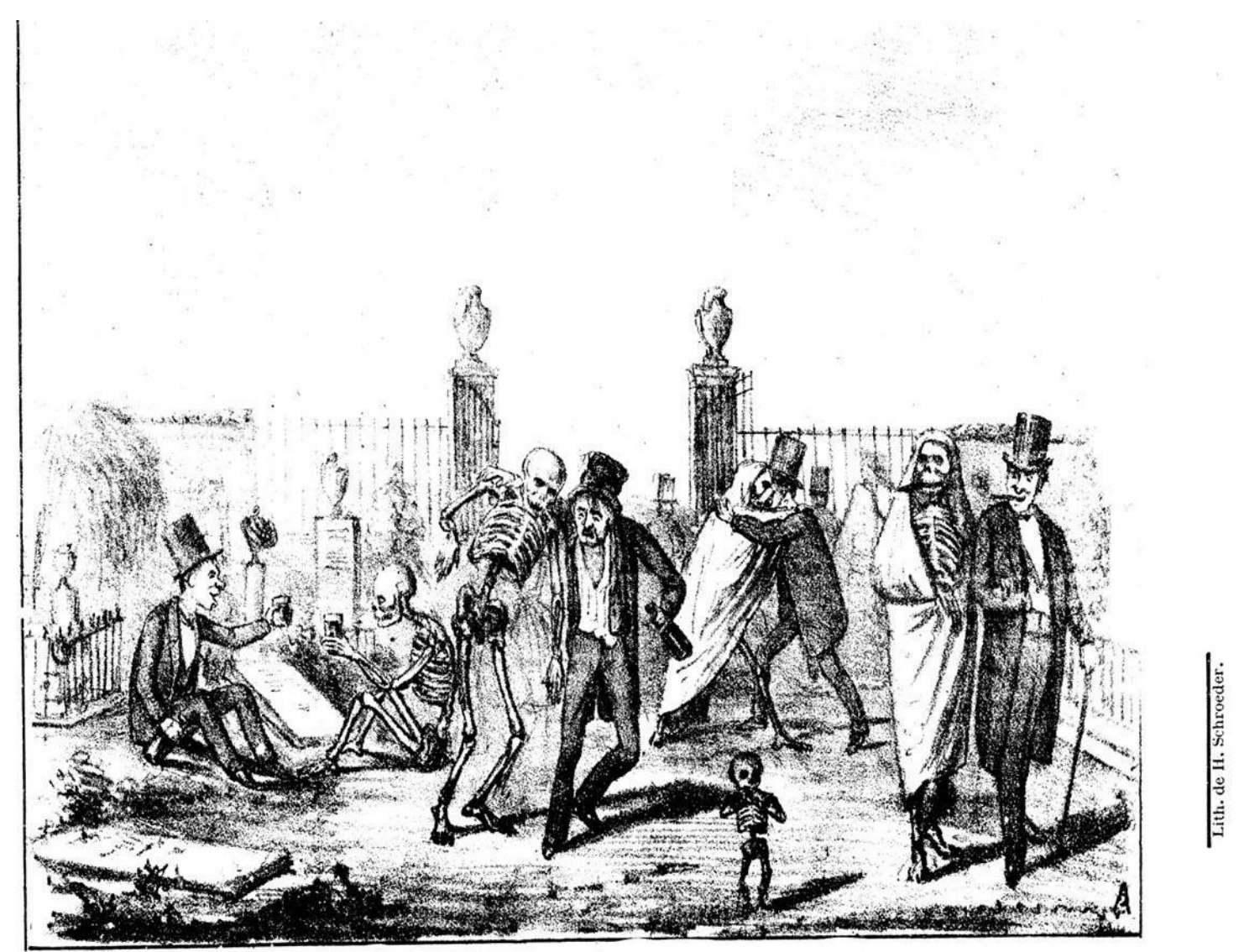

0 Cemiterio da Consolação no dia de finados.

Figura 1 
Diante da escabrosa confraternização sugerida pelo jornalzinho, Silva alegava que a estampa atentava contra a moral e a religião; que defuntos enterrados em um cemitério público haviam sido ridicularizados e constrangidos, numa atitude desrespeitosa que incluía, até mesmo... profanação de cadáver. O suposto delito foi enquadrado no artigo 279 do Código Criminal do Império e, apesar de inciada como uma ação privada, o processo em seguida foi aceito pelo promotor público. Oficializada a acusação, inciou-se ação penal.

Não era a primeira vez que o Cabrião incomodava os setores mais conservadores. Afinal, o periódico de caricaturas tinha no governo imperial o principal alvo de suas sátiras. "O Cabrião veio ao mundo somente para rir e fazer rir", anunciava a edição número 9, de 25 de novembro de 1866. Para chegar ao seu objetivo, não polpava ninguém, nem o Imperador, nem os membros do alto clero, políticos poderosos, a Guerra do Paraguai... No entanto, foi a folia na necrópolis que rendeu ao semanário um processo criminal.

$\mathrm{Na}$ tentativa de se defender e conquistar a simpatia da população local, ${ }^{1}$ seus editores fizeram publicar, no Correio Paulistano de 8 de novembro, uma coluna que explicava os motivos da cena mostrada em suas páginas ilustradas:

Aquela caricatura não ofende nem vivos nem mortos, pela simples razão de que comporta uma coisa impossível.

A sátira ali existente é uma idéia verdadeira, e que está no espírito de todos; refere-se, não aos mortos, que não podem levantar-se de suas sepulturas, mas ao desrespeito que geralmente ostentam os que visitam o cemitério, não como quem vai ali cumprir um ato religioso, mas como quem vai a um lugar de passeio e de pagode, de chapéu na cabeça, charutinho na boca, e a dizer sandices e blasfêmias, como devem muitos ter visto e ouvido, e como está representado na caricatura aludida.

A caricatura exagera os vícios para torná-los bem salientes. Nesse sentido é que deve ser compreendido o painel do cemitério da Consolação, pintado pelo 'Cabrião'."2

\footnotetext{
${ }^{1} \mathrm{O}$ caso é contado na Introdução da edição fac-similar do Cabrião, por Délio Freire dos Santos (Cabrião, 2000).

2 Idem.
} 
A caricatura publicada pelo Cabrião, portanto, nada mais era do que uma afiada e engraçada crítica ao hábito local de se levar farnéis e bebidas ao cemitério no dia de finados.

Literatos e figuras da oposição manifestaram-se em defesa do jornal. Ainda pelo Correio Paulistano, Fagundes Varella, sob pseudônimo, teria escrito um artigo sugerindo que, indiretamente, era o próprio governo quem estaria interessado em mover a ação, numa tentativa de calar o periódico que tantas vezes lhe fizera chacota. $O$ interessante é o comentário do autor a respeito da repercussão do caso na sociedade: "é o tema exclusivo de todas as palestras, a questão pendente de todas as reuniões, a novidade das novidades por todos os cantos da cidade (...).,”3

Pois o famoso "processo do Cabrião", como o caso ficou conhecido à época, terminou bem: concluiu-se que os defuntos não haviam sido ofendidos, a estampa foi considerada inocente e os responsáveis por sua publicação, absolvidos. Mas é claro que, para um veículo dedicado à crítica social em tom humorístico, o episódio rendeu pequenas notas divertidas nas edições seguintes, além de diversas outras ilustrações, que apresentavam os mortos da Consolação indo à delegacia com o semanário nas mãos prestar denúncia com cara de poucos amigos (edição 7); vestidos de policiais, lendo o Diário e assombrando o Cabrião ${ }^{4}$ de noite, disfarçados de fantasmas, (edição 9), ou até mesmo festejando em um grande baile o fim da pendenga (edição 12).

Para além de todas as polêmicas relativas ao processo, um momento particularmente intrigante do entrave foi a tentativa de justificar a famigerada estampa em um artigo pulicado em 14 de novembro, também no Correio Paulistano. Com o título "'As danças dos cemitérios' ou 'A dança dos mortos", o texto, assinado pelo pseudônimo "Arcesilao"5 tratava de enumerar exemplares de danças macabras até o século XVI, entre elas, um baixo relevo num cemitério de Dresden, de 1534; uma na Igreja de São Miguel em Caventry, na Inglaterra; uma na Igreja dos Dominincanos em

\footnotetext{
${ }^{3}$ Citado em artigo de Vicente de Paulo Vicente de Azevedo, publicado em 20 de março de 1965, pelo Estado de São Paulo (Suplemento Literário, p. 4). O texto era a terceira parte de um longo comentário analítico sobre A escola byroniana no Brasil, de Pires de Almeida.

${ }^{4} \mathrm{O}$ personagem criado pelo jornal, inspirado pelo Cabrion, de "Mistérios de Paris", de Eugène Sue. O Cabrião é a figura fictícia que narra e comenta as notícias dadas pela publicação.

${ }^{5}$ Segundo Délio F. dos Santos (Cabrião, 2000, p. XXXVIII), tratava-se do escritor Ricardo Viscotti de Castellazzo, amigo de Agostini, o autor do desenho. Essa hipótese se fortalece pelas menções que Agostini faz nas ilustrações dos números 3,4 e 5 do Cabrião, a um "Arcesilao, autor de $O$ livro do democrata" - título esse do livro de Castellazzo. No entanto, de acordo com o artigo de Vicente de Azevedo (ver nota 3), tratava-se de Américo dos Campos, um dos proprietários do Cabrião.
} 
Strassbourg e uma na Igreja de La Chaise-Dieu na França; as duas danças da Basiléia, o exemplar do convento dominicano em Berna - todas essas do século XV -; gravuras de Holbein de 1530, entre muitas outras, cerca de 20, no total.

$\mathrm{O}$ argumento proposto pelo autor na defesa do Cabrião era de que: "Estas danças com seus regabofes ou sem eles, com dançados ou sem eles, não são cousa nova" lembrança de processar alguém”, pois tais imagens nunca haviam configurado desprezo aos mortos ou aos cemitérios.

Curiosa associação essa, levantada pelo artigo, que remete a um imaginário tão distante no tempo e no espaço. O caso do Cabrião mostra que, no repertório do meio intelectual de meados do século XIX no Brasil, circulavam certas tópicas alheias ao senso comum. De onde teria vindo essa referência tão direta às danças macabras, que não só não fazem parte da cultura popular brasileira como são expressões da cultura européia medieval, sem análogos no Brasil?

A descoberta da dança macabra do Cabrião assombra o interessado pelo tema. Mas o exemplar do jornalzinho parece não ser um surpreendente caso único. A estupefação aumenta diante de um poema como A orgia dos duendes, de 1865, de Bernardo Guimarães. Um dos nossos mais importantes autores românticos coloca em cena cadáveres misturados à figuras do folclore local brasileiro, confraternizando com bruxas, demônios, duendes, como em um frenético e tresloucado sabá. O poema faz parte de uma produção de cunho mais marginal, diferente de tudo o que fez a fama do poeta e romancista mineiro. O desvairado festejo tem música, baile, comilança e deboche. A imagem que A orgia dos duendes produz nos remete diretamente à ilustração do Cabrião, publicada apenas um ano depois. Seria possivel relacioná-la também à dança dos mortos? Na tentativa de responder a essa dúvida e de melhor compreender essas manifestações extemporâneas e deslocadas do macabro, faz-se necessário um retorno às origens do fenômeno.

As danças macabras surgem no contexto da Baixa Idade Média cristã, decorrentes de uma série de elementos próprios daquela conjuntura: a Peste Negra, a guerra dos Cem Anos, grandes fomes, uma maior diversidade de ofícios graças ao crescimento urbano, a valorização crescente do material em detrimento do espiritual,

\footnotetext{
${ }^{6}$ Cabrião, 2000, p. XXXVIII.
} 
mudanças em relação ao conceito de morte... esses fatores somados culminariam nessas obras que juntam, em um mesmo cenário, pessoas e... cadáveres. Daí sua novidade.

A historigrafia da morte, em geral, admite que os últimos séculos medievais desenvolveram um intenso interesse pelos processos de decomposição do corpo humano. É como se o espírito do final da Idade Média não pudesse enxergar a morte sob outro aspecto além do da deterioração, diz Johan Huizinga. Não era à toa. Em uma época castigada por carestias e epidemias, era fácil um homem presenciar uma morte terrível e projetar, nela, seu próprio fim. Com um realismo mórbido, os artistas se esforçam em traduzir o caráter horrível da peste, insistindo nos trespasses fulminantes e naquilo que o contágio tinha de mais odioso, inumano e repugnante.

O fascínio pela morte física e pela putrefação era particularmente observável nas representações dos processos post-mortem na iconografia e na literatura - o que se convencionou chamar, portanto, de "macabro". O termo, desde então, passa a denominar toda referência ao corpo após a morte, em seus estágios de decomposição, até a revelação do esqueleto. Uma série de manifestações do macabro aparecem na passagem para o Renascimento, sendo as mais importantes delas o Encontro do três mortos com os três vivos, as Danças Macabras e os Triunfos da Morte. É dessa primeira etapa da sensibilidade macabra que trata o capítulo 1.

O final do século XVIII redescobre os temas da cultura medieval, tendo por fio condutor a já conhecida obsessão dos românticos pelo período. O imaginário macabro, que tinha conhecido um verdadeiro obscurecimento nos séculos modernos, retorna com todo seu vigor atráves da interpretação de suas tópicas pelo Romantismo, seja atráves de sua vertente frenética, de origem inglesa, seja através da poesia francesa mal de vivre. A retomada da cultura medieval explicaria, em parte, o reaparecimento dos cadáveres decompostos na literatura romântica, mas o desenvolvimento do conceito de sublime pela filosofia ajudar a compreender como o morto e sua podridão passam a ser considerados objeto de fruição estética. Devedor dos temas do Romantismo europeu, em especial do francês, cujos autores eram lidos no original, o Romantismo no Brasil também repercute essa nova configuração do macabro. O capítulo 2 tratará de traçar esse itinerário.

Nesse processo de adaptação do macabro medieval, chama a atenção a maneira como os românticos se reapropriaram do antigo tema das danças macabras, 
modificando-o não apenas na estrutura, mas em seu desenvolvimento. As danças românticas perdem o caráter didático, pedra de toque das originais, e focam nos elementos fantasiosos e terroríficos (brumas, o toque da meia-noite, mortos que voltam à vida no meio da escuridão da madrugada, as louças sepulcrais que misteriosamente se levantam). O capítulo 3 procura levantar uma espécie de inventário dessa produção, seja na prosa ou na poesia, mostrando como as danças contemporâneas passaram a configurar verdadeiros festins de defuntos.

Tal como as festas carnavalescas populares, que invertem a ordem normativa do mundo, o retorno dos mortos à superfície pode ser considerado uma transgressão da realidade tangível - daí o conceito de carnavalização poder ser uma chave interpretativa do macabro. O quarto capítulo de nossa pesquisa se propõe a verificar essa possibilidade. Também será comentada a fabulação da Morte que invade o baile de Carnaval, presente tanto no fim da Idade Média quanto no século XIX, que se confunde com a da dança macabra, potencializando ainda mais o impacto da entrada do medo de morrer no espaço-tempo da folia e do excesso.

Por fim, o capítulo 5 é dedicado à leitura de um dos exemplares mais especiais de dança macabra já produzidos: o poema A orgia dos duendes. Os versos, parte da produção dita irregular de Bernardo Guimarães, foram subestimados e praticamente esquecidos por quase um século pelos críticos literários. Quando se torna alvo do interesse dos estudiosos, a Orgia revela-se como obra densa, repleta de referências cujas camadas vão sendo continuamente reveladas. Filiá-la à tradição macabra é mais uma contribuição para sua incipiente fortuna crítica.

Essa é, portanto, a história da transmissão de uma idéia. Ela poderia ir muito além do período ao qual se limita - optou-se, contudo, pela literatura de caráter romântico feita até, aproximadamente, a década de 1880 . O recorte mostrou-se mais do que necessário. Os momentos posteriores já encontrariam outros modos de compreender a morte, que escapam ao nosso escopo. A intensa medicalização do óbito, o surgimento de empresas que monetarizam sobre o cadáver e o crescimento da prática da cremação, que elimina totalmente o despojo, resultam em manifestações outras do imaginário macabro, que frutificam majestosas na Belle Époque ocidental, notadamente no Simbolismo, e se intensificam com a irrupção da Primeira Guerra Mundial.

O assunto, como se vê, é inesgotável. Passemos, agora, ao seu início. 


\section{Origens do macabro}

Je fis de macabre la danse Qui toutes gens mène à sa tresse

Et a la fosse les adresse Qui est leur dernière maison

Jean Le Fèvre, ca. 1376

L'homme n'est que charogne et sac à vermines Pierre de Nesson, 1461

O imaginário macabro nasce e se desenvolve no contexto medieval, mais especificamente, em seus momentos finais, na chamada Baixa Idade Média. Ele representa uma certa concepção da existência humana, e se manifesta, via de regra, na iconografia e na literatura do período. ${ }^{7}$ Se até o século XIV, aproximadamente, ${ }^{8}$ predominava na cristandade a noção que contrapunha alma e corpo, sendo a morte uma libertação da alma (imaterial e imortal) de seu invólucro terrestre - e, portanto, passagem para uma outra existência, mais importante e plena, -, os séculos seguintes testemunharam uma mudança de fundo na maneira em que o medievo percebia o óbito. Como se houvesse uma maior valorização do "aqui e agora", a morte passava a ser vista, também e cada vez mais, como um fim. Não que deixasse de ser uma travessia; a fé na continuidade da alma permanecia. Mas perdia espaço para uma maior crença na vida material.

A existência tornava-se, assim, menos "transcedental" e crescia, nos homens, a percepção de si enquanto indivíduos atuantes em uma realidade empírica. A vida

\footnotetext{
${ }^{7}$ Essa ressalva refere-se à questão específica e não resolvida das danças macabras - se estas seriam ou não registros de práticas populares, como procissões ou encenações em festas populares. Os autores não entram em um consenso, mas a maioria não vê esse vínculo, pelo menos não nas origens das danças. $\mathrm{O}$ assunto será melhor discutido mais adiante.

${ }^{8}$ Seguramente, esses recortes históricos não têm precisão matemática. Como será visto, mesmo os séculos anteriores ao XIV já assistiam à geração de uma nova forma de se conceber a morte - ela, no entanto, amadurecerá mais adiante.
} 
deixava, gradualmente, de ser, apenas, preparação para o grande trespasse. Tanto valor quanto o "além", passava a ter também o que se era, o que se tinha, o que se fazia e o que se deixava no mundo. A noção de identidade pessoal progredia na medida em que práticas relativas à privacidade, como a confissão, o diário e a escritura de cartas pessoais, entre outras, emergiam. ${ }^{9}$ A arte dedicava-se cada vez mais ao retrato; a Igreja incentivava a confissão - a narrativa dos próprios pecados. Os cuidados com o corpo aumentam, ${ }^{10}$ uma vez que se reconhece, nele, o vínculo com essa existência terrena valorizada. $^{11}$

Se o corpo material era tão importante quanto a alma que ele continha, naturalmente ele passava a ser alvo de grande curiosidade - mesmo depois de morto. " $A$ morte tornou-se o lugar em que o homem melhor tomou consciência de si mesmo." $" 12$ A ciência, gradativamente, começava a estudar a anatomia humana e realizar análises e dissecações, o que era, até então, proibido pela Igreja. O destino do cadáver tornava-se uma preocupação e o fim da Idade Média testemunhou o surgimento das primeiras identificações lapidares, que traduziam o desejo em se individualizar o local da sepultura para que a memória corpórea permanecesse, e consequentemente, sua lembrança física no mundo. Os ofícios dos mortos, que escondiam os corpos em mortalhas e esquifes, deixavam agora o defunto exposto, para que fosse reconhecido e homenageado. $^{13}$

Por extensão, o período teria desenvolvido um interesse obsessivo pelos processos de decomposição. "É como se o espírito do final da Idade Média não pudesse enxergar a morte sob outro aspecto além do da deterioração." 14

Não foi à toa. Em uma época castigada por fomes e epidemias, era fácil um homem presenciar uma morte terrível e projetar, nela, seu próprio fim. O século XIV,

\footnotetext{
${ }^{9}$ Sobre o surgimento da consciência de si na Baixa Idade Média, ver História da vida privada. Da Europa feudal à Renascença, em especial, o capítulo "A emergência do indivíduo". (DUBY e ARIÈS, 1990, p. 503-619.)

${ }^{10}$ Sobre esse assunto, ver: VIGARELLO, Georges. O limpo e o sujo. Uma história da higiene corporal. São Paulo: Martins Fontes, 2002.

${ }^{11}$ Não é por acaso que esse momento vê também o nascimento da moda, como resultante de uma maior preocupação com a aparência do corpo físico. Ver, a respeito: BOUCHER, François. História do vestuário no Ocidente. São Paulo: Cosac Naify, 2010.

${ }^{12}$ ARIÈS, 2003, 58.

${ }^{13}$ Sobre as práticas funerárias da Idade Média, ver o capítulo “A morte de si mesmo”, In: ARIÈS, 2003, p. $46-63$.

${ }^{14}$ HUIZINGA, 2010, p. 221.
} 
em especial, acumulou catástrofes e perturbações sociais, ${ }^{15}$ além de uma profunda crise econômica e demográfica. Frequentes guerras, entre elas a dos Cem Anos, e a chegada da Peste Negra no continente europeu, desestabilizaram o Ocidente medieval, desencadeando um novo olhar sobre a morte.

\section{A influência da Peste}

Sabe-se que o surto de peste bubônica, iniciado em 1348, que foi chamado de Peste Negra, causou um grande impacto às sensibilidades da época. A quantidade assustadora de vítimas dizimadas pelo flagelo (mais de 25 milhões em dez anos, um terço da população européia), ${ }^{16}$ um mal generalizado, que atacava indiscriminadamente, que não cedia ou amenizava diante de nenhum remédio conhecido e ceifava populações inteiras em poucos dias, fazia da morte um evento cotidiano.

É famoso o relato de Boccaccio, no Decamerão, sobre sua chegada no continente a partir de Florença. Nele, é tocante o sofrimento dos inúmeros moribundos, que, abandonados pelos familiares e amigos, agonizavam sozinhos. Seus corpos, horrivelmente deformados pelos bubões que se espalhavam e rompiam, liberavam líquidos fétidos e o odor de podredume tomava conta das casas infectadas. As pessoas morriam a todo instante, em qualquer lugar, e não havia meios de transportar e até mesmo de enterrar a todos. A ferocidade do contágio causava espanto: "Essa peste foi de extrema violência; pois ela atirava-se contra os sãos, a partir dos doentes, sempre que doentes e são estivessem juntos. "17

Nesse contexto, os rituais fúnubres eram improváveis, ("Tais cerimônias quase se extinguiram, no todo ou parcialmente, quando principiou a crescer o furor da peste. "18) o que tornava o evento dessas mortes ainda mais estupefante.

\footnotetext{
${ }^{15}$ Sobre esse assunto, ver o capítulo "As transformações dos séculos XIV e XV”, In: PIRENNE, 1968, p. 197-227.

${ }^{16}$ PIRENNE, 1968, p. 200.

${ }^{17}$ BOCCACCIO, 1971, p. 16.

${ }^{18}$ Idem, Ibidem, p. 17.
} 
$\mathrm{O}$ tratamento dado às pessoas mais pobres, e à maioria da gente da classe média era ainda de maior miséria. Em sua maioria, tal gente era retida nas próprias casas, ou por esperança, ou por pobreza. Ficando, dêste modo, nas proximidades dos doentes e dos mortos, os que sobreviviam ficavam doentes aos milhares por dia; como não eram medicados, nem recebia ajuda de espécie alguma, morriam todos quase sem redenção. Muitios eram os que findavam seus dias na rua, de dia ou de noite. (...) A tal estado chegou a coisa, que não se tratava, quantos aos homens que morriam, com mais carinho do que se trata agora das cabras. ${ }^{19}$

Pode-se imaginar como as histórias sobre as valas comunais dos cemitérios transbordando de cadáveres fétidos e das pilhas de corpos putrefatos acumulando-se nas cidades e vilas em toda a Europa, tenham ficado de herança para as gerações seguintes. Em apenas 5 anos, todo o continente estava infectado, da chegada pelo Mediterrâneo em 1347 à Itália, norte da Espanha, França, em 1348; atravessando o mar e tomando a Inglaterra e a Irlanda, retornando ao norte da França até a Flandres em 1349; chegando aos Balcãs, à Renania, à Alemanha, Dinamarca, Suécia e Hungria em 1350, no ano seguinte avança em direção às regiões bálticas, Polônia, Lituânia e, em 1352, ao coração da Rússia. $^{20}$ A epidemia não cessou plenamente e focos da doença reapareciam esporadicamente em diversos lugares durante os três séculos seguintes ("on peut dire que chaque génération connaît, entre 1348 et 1460, au moins une épidémie meurtrière. Il y eut 14 épidémies en Espagne, plus de 10 à Hambourg, à Cologne, plusieurs à paris aussi. $\left.{ }^{, 21}\right)$, relembrando a sua rapidez e crueldade.

Como consequência destes complexos processos sociais, culturais, mentais, o corpo morto passava a ser reinterpretado. “Com um realismo mórbido, os artistas se esforçam em traduzir o caráter horrível da peste e o pesadelo acordado vivido pelos contemporâneos. Insistiram nos trespasses fulminantes e naquilo que o contágio tinha de mais odioso, inumano e repugnante. ${ }^{22}$ Esse fascínio pela morte física era particularmente observável na presença da representação dos processos post-mortem na iconografia e na literatura - o que se convencionou chamar de "macabro": "o adjetivo

\footnotetext{
${ }^{19}$ Idem, Ibidem, p. 17-18.

${ }^{20}$ VOVELLE, 1983, p. 91.

${ }^{21}$ UTZINGER, 1996, p. 33.

${ }^{22}$ DELUMEAU, 2009, p. 191.
} 
que para nós adquiriu uma nuance de significado tão nítido e próprio, a ponto de, com ele podermos marcar toda a visão de morte do fim do período medieval. ",23

Assim, "costumam-se chamar "macabras" as representações realistas do corpo humano durante a sua decomposição. O macabro medieval começa depois da morte e pára no esqueleto dessecado", ${ }^{24}$ ou seja, é a morte úmida, o estágio de "transi", como passou a ser denominado essa condição transitória da dissolução. Seja como cadáver repulsivo, corpo ressequido ou esqueleto, o morto era mostrado e descrito de uma maneira sem antecedentes. Insiste-se na exposição da podridão, em especial do abdômen - estufado ou aberto, abarrotado de vermes exaltados ou vazio, com as peles penduradas. "Isso significa que se quer mostrar o que não se vê, o que se passa debaixo da terra e que é, na maioria das vezes, escondido dos vivos. ${ }^{, 25}$

\section{A historiografia do macabro}

O fenômeno do desenvolvimento da estética macabra não passou despercebido e suscitou interpretações diversas entre os historiadores. Dos estudos mais fundamentais sobre o tema, destaca-se os comentários de Johan Huizinga, em $O$ outono da Idade Média, de 1919, que via o macabro como mais um sintoma do fim de uma época, em que a morte adquire caráter fatalista e exagerado, acompanhando os eventos traumáticos da Peste, das guerras e das crises alimentícias e demográficas que marcaram o período. Por outro lado, Alberto Tenenti, em outro texto necessário, Il senso della morte e l'amore della vita nel Rinascimento, de 1957, entende o macabro como evidência de uma nova sensibilidade a respeito do humano. Ele seria resultado dos questionamentos acerca de Deus e do lugar do homem no mundo, que revelam uma maior ênfase no material, no corpo - um novo posicionamento, mais positivo, do indivíduo acerca de si mesmo, que seria prêambulo da cultura renascentista subsequente.

Posteriores à Huizinga e à Tenenti, uma outra geração de historiadores das mentalidades, vinculada à tradição francesa iniciada pelos Annales, formados nas

\footnotetext{
${ }^{23}$ HUIZINGA, 2010, p. 231.

${ }^{24}$ ARIÈS, 1989, p. 118.

25 ARIÈS, 2003, p. 140.
} 
décadas de 1960 e 1970, pôde conciliar as duas abordagens e observá-las em fontes iconográficas e literárias, como é o caso de Philippe Ariès em Essais sur l'histoire de la mort en Occident du Moyen Âge à nos jours, de 1975, e L'homme devant la mort de 1977, ou em documentos até então pouco explorados pela historiografia, como os testamentos e os altares às almas no purgatório - no caso de Michel Vovelle, em uma longa pesquisa que produziu, entre outros títulos, Mourir autrefois, de 1974, e La mort et l'Occident, de 1300 à nos jours, de $1983 .{ }^{26}$ Esse posicionamento sobre o macabro se manteve em trabalhos que tocam na questão da morte no Ocidente medieval e já usam como referência os estudos de Ariès e Vovelle, como o de Jean Delumeau, La peur en Occident, de 1978, e, mais tardiamente, o de Jean-Claude Schmitt, Les revenants: les vivants et les morts dans la société médiévale, de 1994, entre outros. Também no âmbito deste trabalho, compartilharemos da abordagem, que entende o imaginário macabro tanto como resposta às grandes taxas demográficas e crises sociais do período, como quanto reflexo de um desenvolvimento maior da consciência de si - na trilha da hipótese levantada pelo antropólogo Edgar Morin em L'homme et la mort, de 1970. Neste texto fundamental, que influenciou profundamente os historiadores das mentalidades, Morin defende a tese de que existia, nas antigas sociedades, uma relação entre as atitudes destas diante da morte e a consciência individual. ${ }^{27}$ Neste sentido, o

\footnotetext{
${ }^{26}$ Os textos de Philippe Ariès e Michel Vovelle sobre a história da morte no Ocidente são as mais conhecidas contribuições para as pesquisas na área - em especial o primeiro, verdadeiro bastião, onipresente nos estudos sobre a morte em qualquer área acadêmica. No entanto, apesar de contemporâneos, os autores propõem vias opostas para o entendimento das concepções da morte na cultura ocidental cristã. Ariès, a partir do exame de conjuntos documentários diversos e heterogêneos (literários, litúrgicos, testamentários, epigráficos e iconográficos) buscava em suas fontes "a expressão inconsciente de uma sensibilidade coletiva". Nem políticas, nem econômicas, tampouco culturais: as evoluções analisadas parecem ser sempre do dominío psicológico, fazem parte das transformações do equipamento mental humano. Quando colocadas na perspectiva de uma história de longa duração, sua narrativa sobre as mentalidades em relação à morte se aproxima muito de uma "psico-história". No caso de Vovelle, sua metodologia vai no sentido contrário: contempla diferentes dados materiais das sociedades deles extrair uma possível "mentalidade" da época estudada. Sendo assim, para se fazer, por exemplo, a história da morte, é preciso tomar a morte como um todo: considerar informações brutas sobre o óbito (as curvas demográficas, ocorrências de epidemias, fomes, guerras, etc), passando pelos rituais e gestos fúnebres até as produções mais elaboradas, literárias ou estéticas, do sentimento da morte. Isso porque, para Vovelle, em franca oposição ao sistema de Ariès, as modificações no entendimento do fim da vida não ocorrem somente por intermédio de engrenagens mentais que se movimentam, mas porque todas as estruturas da sociedade entram em choque - e afetam não apenas a visão da morte, mas todo o sistema de valores e de sensibilidades.

${ }^{27}$ Que, até então, era inexistente. Conforme Ariès, herdeiro dessas noções inauguradas por Edgar Morin, A morte tal como a vida não é um ato apenas individual e expressa a conviçção de que a vida humana não é um destino particular mas um elo do phylum fundamental e initerrupto (...) Uma primeira solidariedade submetia assim o indivíduo ao passado e ao futuro da espécie. Uma segunda, o mergulhava em sua comunidade que participava ativamente dos seus momentos finais. A morte não era portanto um drama pessoal, mas a prova da comunidade encarregada de manter a continuidade da espécie. (ARIÈS, 2000, p. 658)
} 
surgimento do macabro, enquanto conjunto de manifestações relacionadas à decomposição do cadáver, confirmaria sua teoria, já que, para o autor,

La terreur de la décomposition n'est autre que la terreur de la perte de l'individualité. (...) L ' horreur de la mort, c'est donc l' émotion, le sentiment ou la conscience d ela perte de son individualité. Emotionchoc, de douleur, de terreur ou d'horreur. Sentiment qui est celui d'une rupture, d'un mal, d'un désastre, c'est-à-dire sentiment traumatique. Conscience enfin d'un vide, d'un néant, qui s'ouvre là où il y avait la plénitude individuelle, c'est-à-dire conscience traumatique. ${ }^{28}$

\section{Antecedentes}

Antes mesmo do imaginário macabro se popularizar no século $\mathrm{XV}$, identificado como a exposição do cadavér e dos processos post-mortem, é possível perceber as pistas de sua gestação. Na arte funerária, por exemplo, é notável o aparecimento de esculturas portando a marca do que se consideraria macabro por volta de meados do século XIV. As efígies tumulares até então, representavam o falecido sobre a sua tumba como jacente, em posição de dormir, de olhos fechados, mãos postas sobre o peito, vestido ou envolvido em mortalha, com expressão calma, plácida. "Les gisants sont sereins et sûrs de leur mort qui est leur vie éternelle." 29 No momento seguinte, porém, surgem imagens impressionantes, mesmo para a época:

l'art de la mort se transforme profondément; toute mort porte la marque de la désolation, de la pourriture, de la consternacion et, pardelà, d'une certaine inquiètude. A l'évidence, en moins d'une génération, la tempête remplace le calme, la torture artistique remplace la sérénité, le rictus remplace le sourire, l'anatomie remplace le vêtement, le ver remplace le vair, le transi remplace le gisant, la pourriture remplace la vie éternelle. ${ }^{30}$

\footnotetext{
${ }^{28}$ MORIN, 1970, p. 70.

${ }^{29}$ UTZINGER, 1996, p 45.

${ }^{30}$. UTZINGER, 1996, p 45.
} 
Na efígie da tumba (um cenotáfio, na verdade) de François de La Sarra (ca. 1363, o monumento foi erigido entre 1380-1400), na Capela de Saint-Antoine, em Vaud, na Suiça, sapos cobrem seu rosto e seus genitais, e serpentes atacam seus braços e pernas (figura 1). O médico Guillaume de Harcigny, cuja sepultura, de 1393, encontrase no Museu de Laon, na França, foi representado com sinais cadavéricos evidentes: um corpo completamente nu, ressequido, com esqueleto já visível por baixo da pele (figura 2).

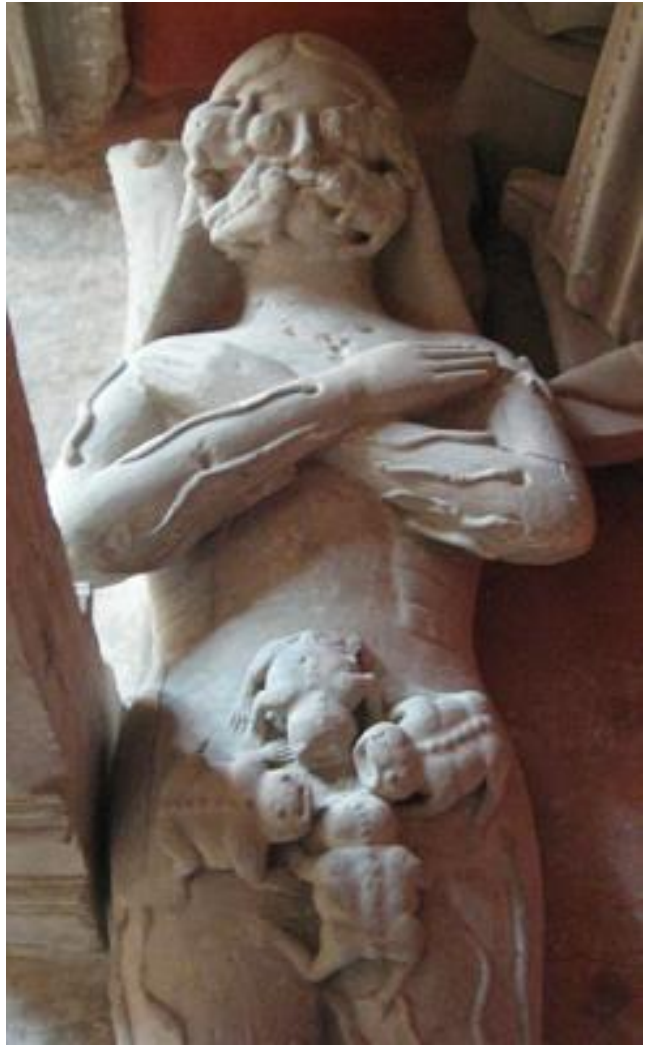

Figura 1

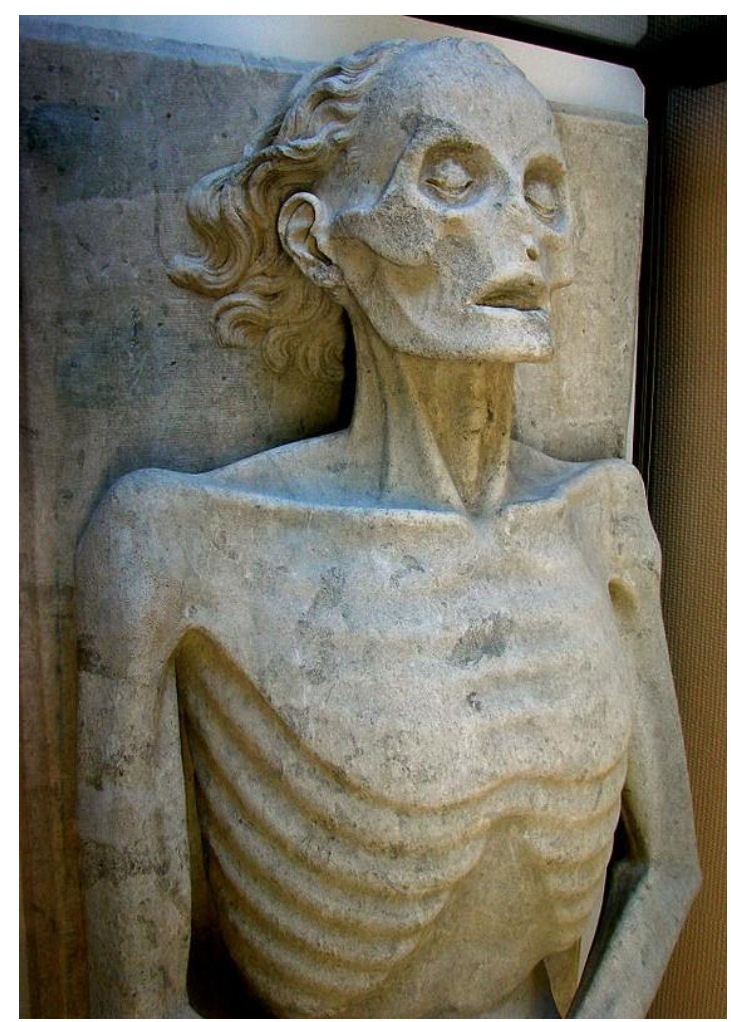

Figura 2

Tumbas compostas, com dois andares, deste mesmo período, mostravam duas esculturas: no andar de cima, uma tradicional de jacente, no de baixo, o cadáver em pleno processo de decomposição - como se quisessem, literalmente, mostrar o que acontece debaixo da terra. O exemplo mais conhecido é a do cardeal Jean Lagrange, falecido por volta do ano 1402, em Avignon, cuja parte de baixo de sua escultura tumular encontra-se no Musée du Petit Palais d'Avignon. Sobre o baixo-relevo que o representa ressequido, lê-se, em latim: "Infeliz! Qual a razão de teu orgulho? Nada mais és que cinzas, e tu serás exatamente como eu, um cadáver fétido, alimento para os 
vermes "31 (figura 3) Este tipo de construção foi feito ainda no monumento do arcebispo Richard Fleming, em 1430, na catedral de Lincoln, e na do arcebispo Henry Chichele, de 1443, na Catedral de Canterbury, ambas na Inglaterra. Incomuns até o século XIV, são contabilizadas cerca de 75 peças desse tipo no século XV, e 160 no XVI. ${ }^{32}$

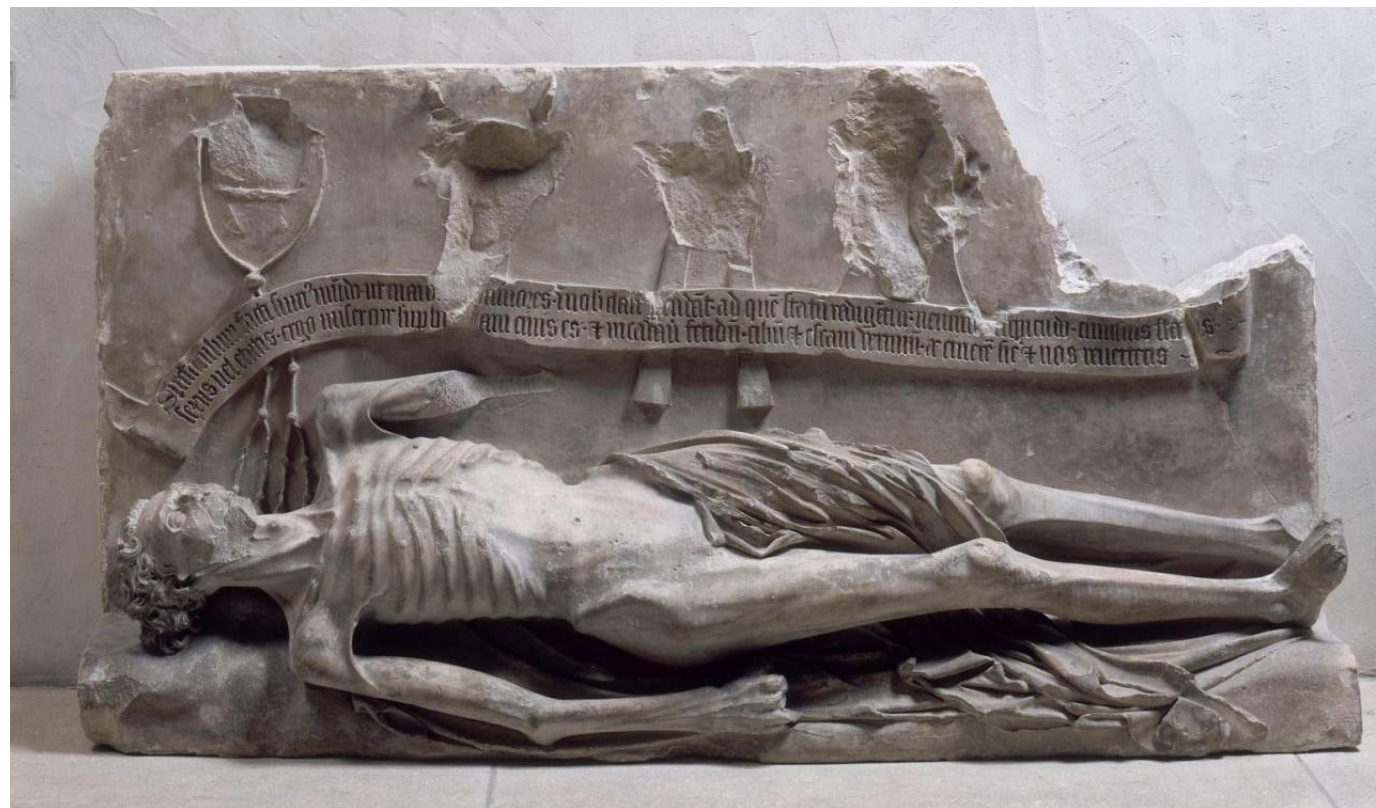

Figura 3

Mas a arte funerária não foi o principal suporte dos temas macabros. ${ }^{33} \mathrm{~A}$ fixação pelo cadáver, ou pelo menos pelos aspectos físicos da decomposição apareciam também na literatura, em exemplos esparsos que remontam ao século XII. Os Versos da Morte, do monge cisterciense Hélinand de Froidmont, compostos entre 1193 e 1197, e o tratado De contemptus mundi, de Lotario de Conti, mais tarde papa Inocêncio III, produzido entre 1194 e 1195, são representativos do terreno fértil em que se formariam os textos macabros.

No poema de Froidmont, escrito em primeira pessoa, o autor se dirige à Morte. Apesar de não ter voz própria no poema, o narrador apresenta-a personificada - uma novidade -, cruel, "ceifadora", que faz armadilhas para suas vítimas ("Morte, tu sabes enfeitiçar"; "Tu és astuta”) 34 , carregando armas ("Tu levantas sobre todos tua clava”; "Tu que, na pedra de amolar, fazes afiar tua navalha”; "A morte sobre eles joga a

\footnotetext{
${ }^{31}$ Traduzido do francês a partir de citação em MÂLE, 1961, p. 136.

${ }^{32}$ ARIÈS, 2003, p. 150.

${ }^{33}$ Idem, ibidem, p. 54.

34 Todos os trechos foram retirados da tradução feita por Heitor Megale para o português. (FROIDMONT, 1996)
} 
faca") e atacando-as de surpresa ("Morte, tu que surpreendes brutalmente / Aqueles que crêem viver muito tempo"), com agressividade ("Morte, fendes de alto a baixo com tua cutilada; Tu sabes muito bem nos aterrorizar"). Em um tom de crítica social, ele pede que ela espalhe suas lições de humildade aos seus conhecidos ("Morte, eu te envio a meus amigos"; "Saúda por mim meus amigos / Inspirando-lhes um santo temor") e às altas hierarquias (ao rei, ao cardeal, ao bispo ["Tu que sabes abater os fortes / Tu que para os potentados fazes a lei / Que reduzes honras a nada / Que fazes tremer os mais poderosos"']), mas que não se esqueça das gentes simples, das mais variadas categorias (“Ó morte, manténs presos os grandes / Assim como nós, pobres campônios”), das mais variadas idades (“A idade não tem nada com o assunto”). O texto insiste nos ensinamentos sobre a morte: sua inevitabilidade, sua imprevisibilidade, a necessidade de se estar preparado para ela, renunciando aos prazeres físicos e mundanos:

Ó morte, se fosse possível

Os ricos pensarem em ti,

Ocupar-se-iam menos com dinheiro,

Amariam menos sua carcaça

E não esfolariam, estes rapaces,

Com suas unhas, os pobres.

Por que tu, morte, tu fincas teus dentes

Mais forte e mais profundamente

Sobre aqueles que, sem trégua, atormentam

Os abandonados a todos os ventos,

Sugam o sangue dos indigentes

E se mostram os mais vorazes. ${ }^{35}$

Já o Contemptus mundi, texto amplamente lido por toda cristandade, inclusive com traduções nas línguas vulgares, causou impacto pela reflexão sobre a vanidade das coisas terrenas, o que incluía o corpo humano: a vida, portanto, nada mais seria do que um constante processo de degradação, sendo o homem fadado ao apodrecimento a partir do momento em que nasce. Sobre o tratado, Bertrand Utzinger comenta que "Il traite avec une violence étonnante la décomposition de la chair-aprés la mort, en terre, mais aussi pendant la vie (...) Il parle de la brièveté de la vie, de la putréfaction, de l'imbécilité et de la laideur de la senilité. Au total, la naissance, la vie et la mortne sont rien que saleté, pourriture et charogne. ${ }^{, 36}$

\footnotetext{
${ }^{35}$ FROIDMONT, 1996, p. 62.

${ }^{36}$ UTZINGER, 1996, p. 56.
} 
Deste caldo literário, fizeram parte também o motivo popular do Debate da alma com o corpo e os temas latinos do Vado mori e da Lamentatio, todos bastante difundidos no século XIII, com os quais diversos poemas foram escritos. No Debate, os dois componentes complementares e antagônicos da natureza humana enfim se separam no momento da expiração e, personificados, e estabelecem um diálogo para desenvolver comentários e queixas sobre si e sobre o outro. A Alma repreende o Corpo por suas fraquezas e por ser responsável pelo seu destino - acusações respondidas pelo Corpo.

Nos outros dois, colocam-se em cena um elenco de homens que representam tipos diversos da sociedade medieval e que, já moribundos, declamam seus lamentos e arrependimentos ao pressentirem a chegada do momento da morte (que começam e terminam com a fórmula “Vou morrer"). Em um manuscrito de Vado Mori, escrito, acredita-se, pelo poeta Hélinant, ${ }^{37}$ conservado na Biblioteca de Mazarine (no. 980, folha 83), em Paris, o papa e o rei iniciam as lamúrias...

Vado mori, papa, qui iussu regna subegit,

Mors mihi regna tulit eccine, vado mori.

Vado mori, rex sum, quid honor, quid gloria regni?

Est via mors hominis regia, vado mori.

... das quais não escapa nem mesmo o homem pobre do povo, que viveu como o Cristo e, por isso, é amado por ele:

Vado mori, pauper, que pauper Christus amavit, Hunc sequar evitans omnia, vado mori. ${ }^{38}$

\footnotetext{
${ }^{37}$ Corvisier, 1998, p. 7.

${ }^{38}$ Retirado de Infantes (1998, p. 65 e 66), que por sua vez copiou de HAMMOND, E.P. Latin Texts of the Dance of Death. MPh, VIII (1910-1911), pp. 399-410.
} 


\section{O encontro dos três mortos com os três vivos}

$\mathrm{Na}$ passagem para os quatrocentos, vem à tona um dos temas principais do desenvolvimento da estética macabra: $O$ encontro dos três mortos com os três vivos. A cena em que três cadáveres reanimados encontram-se e conversam com três homens tornou-se um gênero literário e iconográfico popularíssimo no fim da Idade Média.

No Encontro os vivos não são convidados a partir imediatamente. Trata-se de um aviso para que aproveitem o tempo que lhes resta para praticarem o bem, arrependerem-se e garantirem, assim, uma boa morte. A fórmula Quod fuimus estis, quod sumus eritis está em seu cerne. De origem obscura, provavelmente francesa, é um dos temas responsáveis pela difusão do macabro no Ocidente. Isto se deve à representação plástica dos mortos: via de regra, apresentam os três estágios físicos postmortem - e aí reside sua originalidade. ${ }^{39}$ Distingue-se, assim, graficamente os diferentes momentos: o primeiro cadáver está ainda em bom estado de conservação, possui certas características físicas e sociais (trajes, objetos pessoais) da pessoa que foi, apresentando poucos sinais de deterioração. O segundo, quase nu, às vezes coberto por mortalha, tem o corpo bastante decomposto, o ventre aberto; o terceiro, em geral, é já um esqueleto, ou praticamente um, com restos de pele ressecada colada aos ossos. Como em um espelho, os mortos refletem os vivos, lhes oferecendo a visão de sua aparência futura.

O primeiro texto do Encontro do qual se tem registro é anônimo e data da década de 1280; no entanto, não há cópia preservada deste original. O mais antigo dos manuscritos preservados data de 1295 e é atribuído ao menestrel Baudoin de Condé (1244-1280), da corte da condessa Marguerite de Flandres. Os versos são acompanhados da primeira gravura registrada do gênero, representando a cena. $O$ documento foi depositado na Biblioteca de Arsenal (Ms. 3142) e conta como três jovens nobres e de prestígio, ricamente vestidos, deparam-se, um dia, com três cadáveres desfigurados, comidos pelos vermes. Uma experiência perturbadora enviada por Deus, para provocá-los e fazê-los refletir.

Ainsi que le raconte l'histoire,

\footnotetext{
${ }^{39}$ GLIXELLI, 1914, p. 27.
} 
ils étaient, qui duc, qui comte,

trois hommes nobles de grand prestige

et riche équipage, comme il convient à des fils de roi

et en plus très jolis et pleins de gentillesse.

Ils étaient durs envers tout le monde

qui voisinait leurs terres.

Un jour, pour éprouver leur orgueil,

leur apparaît une vision venant de Dieu, troublante et effrayante à voir des yeux,

et terrifiante: je ne vous mens pas là-dessus:

c'était trois morts mangés par les vers, aux corps enlaidis et défigurés.

Se estabelece um diálogo entre eles, no qual os mortos chamam a atenção dos jovens para seu estado físico, pedindo que os olhem o rosto e o corpo deformados. Deles, que também foram belos rapazes que aproveitavam a vida um dia, restam apenas ossos com cobertos de pele escurecida.

Alors l'un des morts dit aux vivants: "Seigneurs, regardez-nous au visage et puis au corps; nous don't au total arrive l'avoir, voyez ce que nous sommes, ainsi serez-vous et ainsi, comme à présent vous êtes, fûmes-nous il y a quelque temps encore, aussi beaux et d'une même valeur; mais la mort y a prélevé un capital qu'on n'évalue pas en des derniers, car c'est un bien de chair, de peau et de nerfs don't il nous reste peu sur les os, et ce peu est plus noir que mûre. ${ }^{40}$

O texto do Encontro teve diversas versões em línguas vulgares, como no francês, no alemão e no castelhano, entre outras, e os manuscritos eram, normalmente, bastante ilustrados. Acredita-se que o relato tenha entrado para a tradição oral, sendo contado como exempla pelas ordens mendicantes e se espalhado. Seus detalhes eram alterados de acordo com o local em que apareciam, como o estado de decomposição dos mortos ou o grupo social e a faixa etária dos vivos - na França, por exemplo, a lenda

\footnotetext{
${ }^{40}$ retirado de GLIXELLI, 1914.
} 
conta a história de três jovens nobres cavaleiros que saem à caça, com seus cães, quando são surpreendidos. Mas sua essência pedagógica se manteve.

A primeira pintura mural com o tema foi, provavelmente, a da Igreja de SainteSégolène de Metz, do fim do século XIII (destruída entre 1895-1910), momento em que o motivo se populariza, migrando para toda a cristandade. Os exemplares imagéticos mais conhecidos e estudados são o afresco do cemitério do Camposanto de Pisa, de meados do século XIV, e o do convento beneditino de Subiaco, do século XV (figura 4), ambos na Itália. O Encontro foi também amplamente utilizado para ilustrar textos genéricos sobre a morte e em artigos pessoais, como em livros de horas.

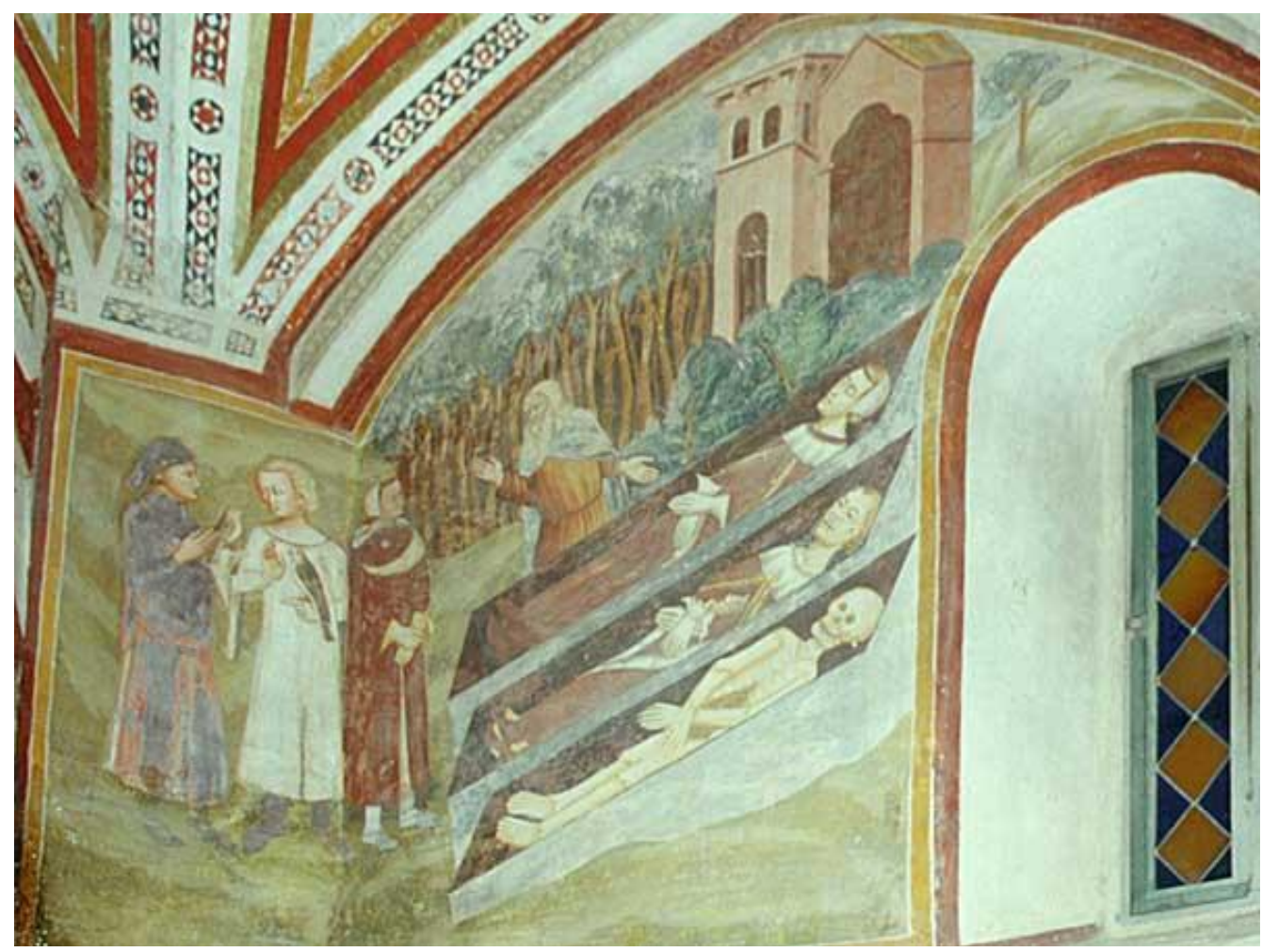

Figura 4

\section{"Macabre"}

Finalmente, na segunda metade do século XIV, teremos o primeiro registro documentado do uso da palavra macabro. Ela aparece nos versos de um pequeno poema 
entitulado Le respit de la mort, escrito por volta de 1376 e, curiosamente, relacionada à palavra dança. Seu autor, um jurista e poeta francês chamado Jean Le Fèvre (13221387), acabava de se restabalecer de uma grave doença e decide contar sua experiência de quase-morte, e o que aprendeu com ela.

L' intencion de 1 acteur Pour venir a mon intencion Je fistz nagaire mencion Pour le mal don't je me douloie Comment respit avoir vouloie Affin que je nallasse mye Le chemin de lespidemye 1 an mil. CCC. soixante et seize Charles le quint regnant lan treze Et de son regne tres eureux Et comme j estoie paoureux En disant helas et my Huit jours apres la Saint Remy Je doubtay de la mort premiere Estaindre vouloit ma lumiere Et moy bouter hors de ce monde Ou nul tant ait $\mathrm{d}$ avoir $\mathrm{n}$ abonde Volente me vint desseoier $\mathrm{Si}$ je pourvoie deloyer Que je $n$ allasse par della Ennuis meurt qui a pris nela Ainsi malades et enfermes Mon autre destrempay de larmes Par escript de main langoreuse Fistz ceste epistre doloureuse. ${ }^{41}$

Seu texto, portanto, é o testemunho de um homem que sabe que esteve muito próximo do fim, amargando suas dores e angústias mais profundas; passa, então, por lenta convalescência e, afinal, agradece a nova chance alcançada de viver. Não é à toa que batiza o poema de Respit, visto que, temporariamente, foi poupado da morte.

O documento está depositado na Biblioteca Nacional da França, em Paris (Ms. fr. 1543, fol. 26Ir) e, a partir do verso 3069, lê-se:

Je vueil respit pareillement En attendant son jugement Mon crediteur et surtout maitre

\footnotetext{
${ }^{41}$ Retirado de UTZINGER, 1996, p. 57.
} 
Souverain roi souverain pretre

$\mathrm{Si}$ je luis dois tribut

Bien voy que c est commun voyage

Toutes gens, toutes nations

Par toutes obligations

Y sont liez de leur naissance

Je fis de macabre la dance

Qui toutes gens maine à sa tresse

Et à la fosse les adressse

Qui est leur dernière maison

Il fait bon en toute saison

Penser a sa fin dernière

Pour en mirer mieux sa maniere ${ }^{42}$

O polêmico verso "je fis de macabre la dance" causa controvérsias e provoca as mais diversas interpretações. Ainda hoje, não se sabe o sentido exato que ele teria, tampouco qual o significado de macabre e ao quê estaria relacionado. Seria uma indicação de algum poema anterior do mesmo autor, que já teria escrito sobre o mesmo assunto? Teria ele utilizado uma expressão comum à sua época? Uma hipótese bastante discutida no século XIX pelos primeiros pesquisadores do macabro, como Francis Douce, é a que propõe que macabre estivesse se referindo a um nome próprio. Le Fèvre estaria, assim, promovendo uma relação da "dança que leva a todos para a fossa" a um sujeito de nome "Macabre". Com a difusão do tema da Dança Macabra, que discutiremos a seguir, diversos manuscritos desse gênero traziam grafias diferentes, o que acabou causando ainda maiores divergências. Macaber, Machabree, Macabré, Macaire, Marcade, Marcabrus, Marcabrum, entre outros, ${ }^{43}$ foram alguns dos nomes àos quais as danças foram atribuídas nas versões e traduções que motivo gerou. ${ }^{44}$

Atrelada a essa hipótese, existe a possibilidade de que Macabre (e suas variações) fosse considerado o autor da primeira dança macabra, uma da qual não se tem evidências comprovadas. Ou ainda, que tenha sido o poeta dos versos que depois foram transcritos em uma Dança no cemitério de Saints-Innocents em Paris, considerada a primeira que se tem registro e da qual a autoria dos versos nunca foi comprovada.

\footnotetext{
${ }^{42}$ retirado de UTZINGER, 1996, p. 57. Grifo meu.

43 exemplos retirados de DOUCE, 1833; LANGLOIS, 1852; INFANTES, 1997.

${ }^{44}$ Como, por exemplo, no caso da tradução para o inglês da primeira dança macabra francesa que, segundo Douce continha o verso "la danse Macabre sapelle" e que na versão inglesa aparece "the daunce of Machabree", o que modificava o sentido do termo e sua grafia. (DOUCE, 1833, p. 29)
} 
"Trata-se de um nome próprio, seja qual for a etimologia da palavra", 45 chegou a afirmar Huizinga, influenciado por essa teoria. Seria impossível, no estágio atual das pesquisas, se assegurar sobre uma das possibilidades, ou mesmo sobre sua procedência. ${ }^{46}$ Mas, se for esta a razão da origem da palavra, é possível pensar que o gênero de obras chamado "Dança Macabra" era, originalmente, a "dança de Macabre", relativo ao artista, independente da grafia correta e, posteriormente, com o uso, transformou-se no adjetivo qualitativo da "dança".

Uma outra tese, mais aceita, é a que aproxima o termo macabro do sobrenome Macabeus, dos sete irmãos mártires do Antigo Testamento. "Não é surpreendente, aliás, que se tenha dado por volta do século XIV, ao "corpo morto" (quase não se usava o termo cadáver) o nome dos santos Macabeus; estes já eram há muito tempo venerados como patronos dos mortos, porque eram considerados, com ou sem razão, inventores das orações de intercessão pelos mortos. " 47 Haveria ainda uma relação com uma suposta "dança dos Macabeus" (chorea Macchabaeorum), ${ }^{48}$ cerimônia na qual um grupo disposto em círculo interpretava a história dos irmãos, que morrem torturados juntos de sua mãe, ou, ainda, a existência de certas solenidades funerárias em que se declamava passagens do Livro dos Macabeus. 49 "Existe, toda una tradición elaborada y documentada hasta el siglo XVI en la que Judas Macabeo pasaba por ser el que intituyó el culto a los muertos. "50

Seria possível, também, porventura, aludir "macabro" à São Macário. O santo não só foi representado ao lado da morte no grande afresco do Triunfo da Morte pintado no Campo Santo de Pisa, ${ }^{51}$ como aparece também em algumas versões do Encontro dos três vivos e dos três mortos, ao lado dos defuntos. ${ }^{52}$ Victor Infantes, talvez o principal estudioso contemporâneo dos temas macabros, indica, a respeito dessa aproximação entre São Macário e os mortos, uma lenda hagiográfica sobre a ressurreição de um morto através de sua intercessão. ${ }^{53} \mathrm{E}$, claro, como em qualquer outra hipótese que busque as raízes obscuras do termo, problemas de tradução e transcrição devem ser

\footnotetext{
${ }^{45}$ HUIZINGA, 2010, p. 231.

${ }^{46}$ INFANTES, 1997, p.23.

${ }^{47}$ ARIÈS, 2011, p. 123.

${ }^{48}$ MÂLE, 1949; CORVISIER, 1998.

${ }^{49} 2$ Macabeus 7, 1-42.

${ }^{50}$ INFANTES, 1997, p. 26.

${ }^{51}$ Idem, ibidem, p. 28.

${ }^{52}$ DOUCE, 1833, p.32.

${ }^{53}$ INFANTES, 1997, p. 28.
} 
considerados: "the Saint's name, wich, in the modern ortography of that language [o francês], is Macaire, would, in many ancient manuscripts, be written Macabre instead of Macaure, the letter $\mathrm{b}$ being substituted for that of $\mathrm{u}$ from the caprice, ignorance, or carelessness of the transcribers. ",54

Outros, ainda, estabeleceram a conexão de macabro com a palavra marcheria, "muro", em baixo latim, devido às pinturas feitas nos muros dos cemitérios (que, em francês, supostamente, teria se transformado em danse du mure, depois, des morts ${ }^{55}$ ). Ou ainda, que poderia ter derivado do árabe Maqbara (singular) e Maqabir (plural) que significaria "túmulo" ou mesmo "cemitério. Este vocábulo, misturou-se ao espanhol popular (que, além de maqabir, utilizava, com o mesmo sentido, almacabra - advindo do português antigo almocávar). Ao passar para a França, teria se relacionado, na língua comum, com o sobrenome Macabeu, originando o termo macabre. Essa transmissão se confirmaria no termo em holandês para as Danças macabras, Makkabeusdans. Soma-se a essa receita o hebreu meqaber, que seria o equivalente à "coveiro" no Antigo Testamento, ${ }^{56}$ sendo, portanto, mais uma palavra envolvida na gênesis de macabro.

De qualquer maneira, a sua aproximação com "dança" voltaria a aparecer em outros manuscritos de datação ainda imprecisa, mas seguramente posteriores ao Respit de la mort. A diferença era que, nesses, ela aparece já com a estrutura e a temática do gênero que seria o mais importante no desenvolvimento e na difusão da estética macabra: a Dança Macabra. Ou seja, entre o seu primeiro registro e esses textos, algum processo ainda não totalmente esclarecido, desembocou nas Danças. Elas traziam, agora, uma composição bastante específica.

\section{As Danças Macabras}

Denomina-se "Dança Macabra" toda obra textual (normalmente em estrutura de poema) ou iconográfica (independente do suporte) - ou ambos -, que apresenta um

\footnotetext{
${ }^{54}$ DOUCE, 1833, p. 34. Langlois traz a mesma hipótese (1852, p. 113)

${ }^{55}$ LANGLOIS, 1852, p. 106.

${ }^{56}$ INFANTES, 1997. Este autor fez um recolhimento minucioso de outras várias hipóteses menos difundidas, a maioria, carecendo de qualquer tipo de prova para se manter; algumas delas parecem advir apenas da intuição dos historiadores que as defendem.
} 
desfile de personagens em que, parte deles está morta, parte, viva. Ele pode se configurar como uma fila ou uma procissão, uma ciranda ou uma cena dançada. É presidida por uma representação da morte personificada, que pode ser múltipla (a mesma personagem que reaparece várias vezes) ou um grupo (vários cadáveres, seus enviados). A morte ou os mortos geralmente aparecem como transis, como cadáveres em decomposição, ou, o que seria mais comum a partir do século XVI, como esqueleto. Em movimento, ela segura ou encaminha, um por um, os vivos. Estes representam a sociedade e são apresentados sempre em hierarquia descedente. Cada qual simboliza uma categoria social, um estágio da vida, um estado emocional, um gênero. Seu contato com um morto significa que está sendo levado a óbito.

Muitas começam e terminam com a presença de um pregador, o que atribui às Danças um aspecto de sermão. Fica claro que, ali, há algo a ser aprendido. Uma característica essencial é que os vivos devem exemplificar figuras existentes na realidade medieval. Não são representação metafóricas ou fantasiosas, mas verossímeis e presentes na sociedade. Assim, entram em cena autoridades laicas como o imperador, o rei, o príncipe, duque, conde, cavaleiro; eclesiáticas como o papa, o cardeal, o bispo, o abade, monges de ordens diversas, pároco, mendicante. Membros das camadas intermediárias, integrantes da sociabilidade urbana, também apareciam, como o burgomestre, o comerciante, o artesão, o trovador; assim como o lavrador, representando a gente simples do campo. Outras categorias diversas como o apaixonado, a criança, o velho, o louco, a mulher (geralmente os personagens eram masculinos, logo, os poucos femininos se destacavam), o cego, o ermitão, etc, também entravam. O elenco variava muito - o que é revelador sobre as escolhas que os autores faziam, das figuras consideradas relevantes para representarem a sociedade, ou mais apropriadas ao local onde faria a obra. ${ }^{57}$ No caso dos textos (ou da presença deles junto com imagens), a dança deve ter configuração de diálogo, entre os vivos e os mortos, como no exemplo retirado da dança macabra de Berna, na Suiça: ${ }^{58}$

\footnotetext{
${ }^{57}$ Isso se observa, principalmente, quando se compara as pinturas feitas nas vilas campesinas ou nas cidades - o "burguês"e o "camponês" variam bastante de posição por esse motivo. O mesmo ocorre com autoridades administrativas (como o condestável, o prefeito, o coletor de impostos) ou tipos tipicamente citadinos (como o padeiro, o vendedor ambulante, o mendicante, etc).

${ }^{58}$ Afresco com versos pintado entre 1516 e 1519, pelo artista suiço Niklaus Manuel Deutsch, em um muro do convento dominicano de Berna. O original foi destruído em 1660, mas cópias em aquarelas foram preservadas e estão expostas no Museu Histórico da cidade.
} 
La mort dit au Comte:

Comte puissant, regardez-moi,

Laissez en repos tous vos équipements,

Recommandez votre pays aux héritiers,

Car vous avez maintenant la mort sous la main!

Réponse du Comte:

Je suis de noble maison

La mort m'est maintenat une triste nouvelle,

J'aurais voulu jouir plus longtemps de ma seigneurie,

Oh, mort veux-tu vraiment mettre fin à ma vie $?^{59}$

É comum, também, a participação de cadáveres que tocam instrumentos musicais - destacando o elemento rítmico do gênero. Nesse sentido, a legitimidade do termo "dança" se daria muito mais pela presença dos transis músicos entre os personagens representados (às vezes abrindo ou fechando o desfile) e, especialmente, pela postura dos mortos que, excitados pela sua função, estão sempre em movimento ao contrário dos vivos que congelam. Essa inversão é, em si mesma, uma sátira: os mortos, animados, parecem muito mais vivos que seus pares.

As expressões "Dança da morte", "Dança dos mortos" ou "Danças macabras" são empregadas indistintamente para denominar o tema, apesar de portarem uma pequena diferença conceitual. Essa seria no sentido de estabelecer a identidade precisa do(s) personagem(ns) morto(s): se se trata de um grupo de mortos que representam a morte ou personificam o evento da morte, ou se é "a" própria Morte, individualizada. Neste caso, a Morte chama à sua dança fatal os vivos; no anterior, o morto que aparece diante do vivo seria, dependendo da interpretação e, às vezes, do que sugere o texto, um personagem aleatório e anônimo, ou uma espécie do duplo do vivo, seu espelho, que reflete o futuro.

A nomenclatura das Danças em outras línguas revela esses usos distintos: no alemão, as mais frequentes são Totentanz ou Todestanz; Dance of death em inglês, Danza de la muerte em espanhol, Dansa de la morte no italiano. No francês, assim como no português, prevaleceu a expressão Danse macabre/Dança macabra. Independente do termo, tratam todos do mesmo gênero.

\footnotetext{
${ }^{59}$ retirado da tradução para o francês de UTZINGER, 1996, p. 296.
} 
O exemplar mais relevante das Danças foi um afresco pintado no cemitério de Saints Innocents, em Paris, em 1424. É considerada a primeira obra registrada do gênero, reunindo texto e imagem. Sua grandiosidade causou um grande impacto à época: na parte interna de um dos muros que cercava o terreno, na pintura de 20 metros de extensão, cerca de 30 personagens eram chamados à dança da morte. Cada um era acompanhado por seu par, um cadáver ressequido, e, abaixo, pelos versos do poema. A obra localizava-se abaixo de um dos carneiros do cemitério, as galerias construídas sobre os muros para receberem os ossos que não estivessem completamente limpos mas que deveriam ser retirados das fossas comunais para abrir espaço para novos corpos. A visão das pilhas de ossos ainda coberto de pele ou carne ressequida combinada à do afresco provavelmente intensificava o efeito da obra. No quadro do artista flamengo anônimo pertencente ao Musée Carnavelet em Paris (c. 1570), é possível observar a área do cemitério, com a igreja ao fundo e os corredores laterais formados pelos muros, pelos carneiros em cima e pelas arcadas internas. A dança estaria do lado direito da imagem (figuras 5 e 6 ).

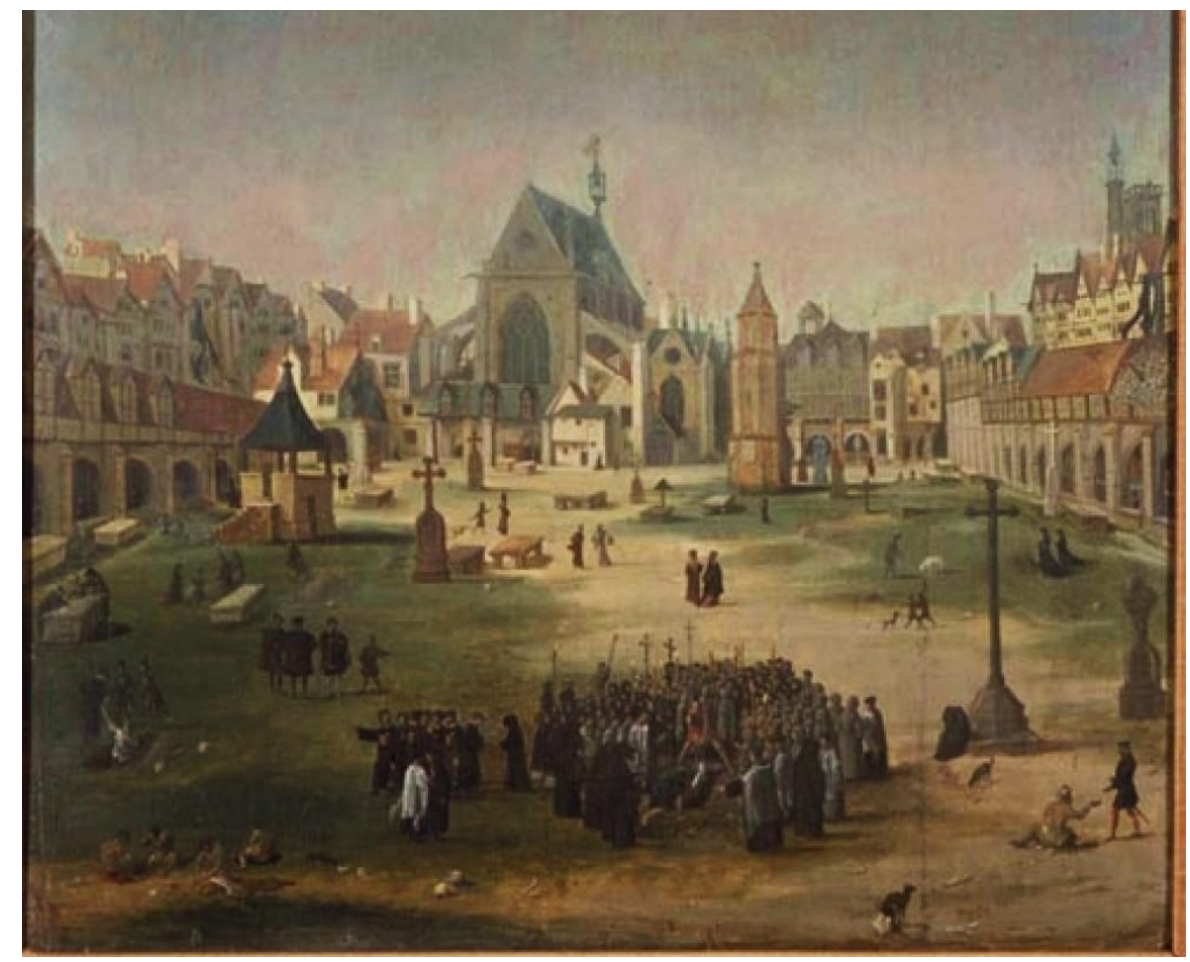

Figura 5. No limiar da margem direita da tela, é possível ver o carneiro repleto de ossos, sobre a galeria em arcos abobadados. 


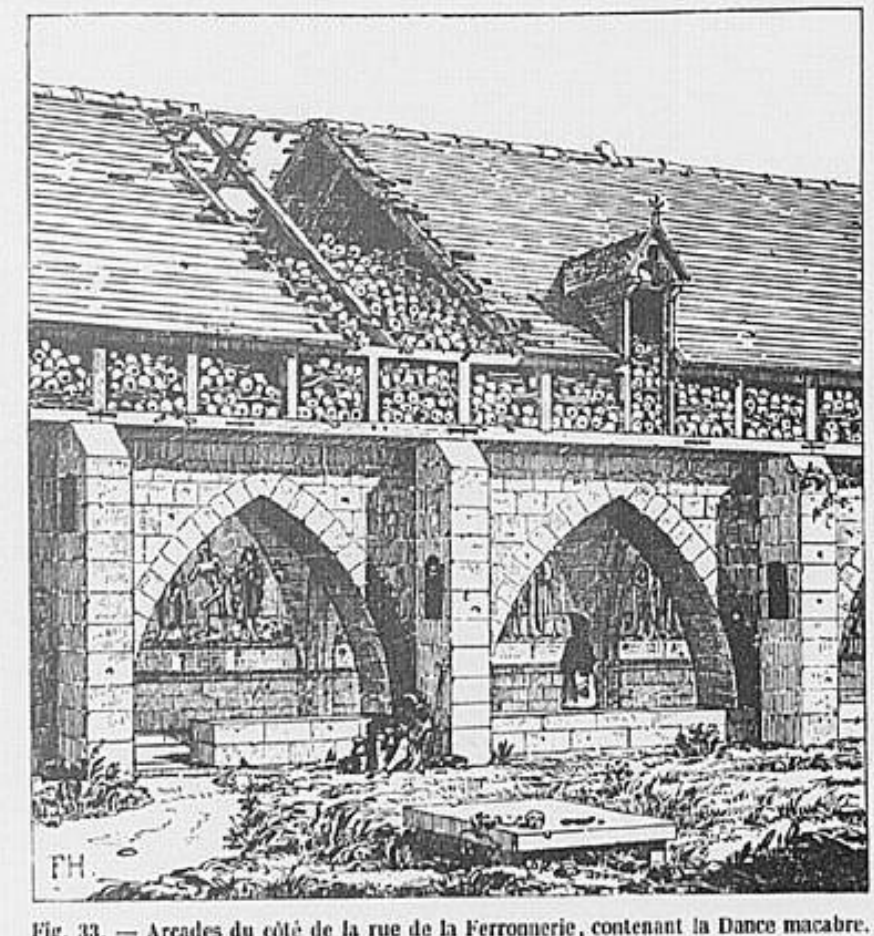

Figura 6: reconstituição da galeria com o carneiro em cima, onde foi pintada a dança macabra de SaintsInnocents, feita pelo arquitetoT. J. H. Hoffbauer, publicada em 1885.

Saints-Innocents era o principal cemitério da capital francesa. Localizado do coração da cidade, no 1er arrondissement, era intensamente utilizado, já que vinte paróquias da região tinham o direito de realizar seus sepultamentos no local, além da igreja de Saints-Innocents da qual era anexo e do Hôtel-Dieu, o hospital para onde iam as vítimas de epidemias e os cadáveres anônimos para serem reclamados. Por isso, estima-se que centenas de pessoas passavam por ali diariamente. Mas sabe-se também que foi um lugar muito frequentado por toda população, espaço de sociabilidade e de comércio: "em meio ao constante enterrar e desenterrar, era um lugar para passear e um ponto de encontro. Havia lojinhas junto aos ossuários e prostitutas sob as arcadas. (...) Até festividades aconteciam ali., 60

Supõe-se que naqueles anos anteriores à confecção do afresco, suas valas comunais estivessem abarrotadas, pois concentravam os mortos vítimas da peste de 1421, da grande fome de 1417 e da guerra contra a Inglaterra, que perdurava. Estima-se

\footnotetext{
${ }^{60}$ HUIZINGA, 2010, p. 240.
} 
cerca de 100 mil mortos enterrados lá em $1418 .{ }^{61}$ Inspiração não faltava, portanto, ao artista anônimo que empreende a grande pintura mural a partir de novembro de $1424 .^{62}$

Apesar de destruída (parte em 1529, totalmente em $1669^{63}$ ), a obra foi demasiadamente documentada e comentada, inspirando a confecção de outros afrescos logo depois de terminada, na Páscoa de $1425 .^{64}$ De Paris, a dança de Saints-Innocents passa muito rapidamente para a Inglaterra. $\mathrm{O}$ poeta e monge beneditino John Lydgate (que esteve em Paris em 1426 e conheceu a dança original ${ }^{65}$ ) teria feito sua primeira tradução por volta de 1430 (The Daunce of Death) e, em 1440, John Carpenter, um burguês enriquecido de Londres, patrocina um afresco pintado em um muro do cemitério do claustro de Saint-Paul, com os versos de Lydgate escritos abaixo.

Dos afrescos feitos logo após a dança parisiense e que resistiram aos séculos, podendo ser visitados ainda hoje, os pesquisadores consideram aquele pertecente à abadia de La Chaise-Dieu o que mais se aproxima da aparência da original (figuras 7 e 8). Trata-se de uma obra interminada e mesmo assim monumental: possui 26 metros de extensão por 1,50 de altura, e é dividida em três grandes painéis, que ocupam uma parede interna da Igreja. Seus 23 personagens, devidamente acompanhados de seus parceiros defuntos, estão separados em grupos correspondentes à sua posição social. Não há consenso sobre a data precisa e sua produção, mas a análise indumentária considera que tenha sido feita até, no máximo, a década de $1480 .{ }^{66}$

\footnotetext{
${ }^{61}$ UTZINGER, 1996, p. 83.

${ }^{62}$ E. Mâle cita o Journal d'un bourgeois de Paris que teria escrito: "L'an 1424 fut faire la danse macabre aux Innocents, et fut commencée environ le moys d'août et achevée au carême ensuivant." (MÂLE, 1961, p. 140). Este documento será melhor comentado no capítulo 3.

${ }^{63}$ Em 1785, todo o cemitério foi removido em um processo de retirada dos cemitérios do centro de Paris. As ossadas foram transferidas para as catacumbas sob a catedral de Notre-Dame. No local, manteve-se apenas uma fonte, que data de 1549 , no centro do quarteirão, que se transfomou em local de feira. Em 1856, a quadra se tornou praça (Place Joachim du Bellay).

${ }^{64}$ ver nota 54.

65 INFANTES, 1998, p. 167.

${ }^{66}$ Os estudiosos que se debruçaram sobre o afresco, como Aimé Brunereau, Pierre Mailon, Patrick Rossi, destacam certos elementos como as mangas longas cujos punhos esbarram no chão, frequentes no século XV e que não eram mais usadas no XVI e, sobretudo, o uso dos sapatos pontudos que portam quase todas as figuras, denominados à la poulaine - grande voga desde meados do século XIV que teve seu apogeu entre 1410 e 1470 até que foi proibido pelo decreto suntuário de 1480, sendo rapidamente substituído por calçados amplos de ponta achatada, o que sugere que a obra foi feita antes desta data.
} 


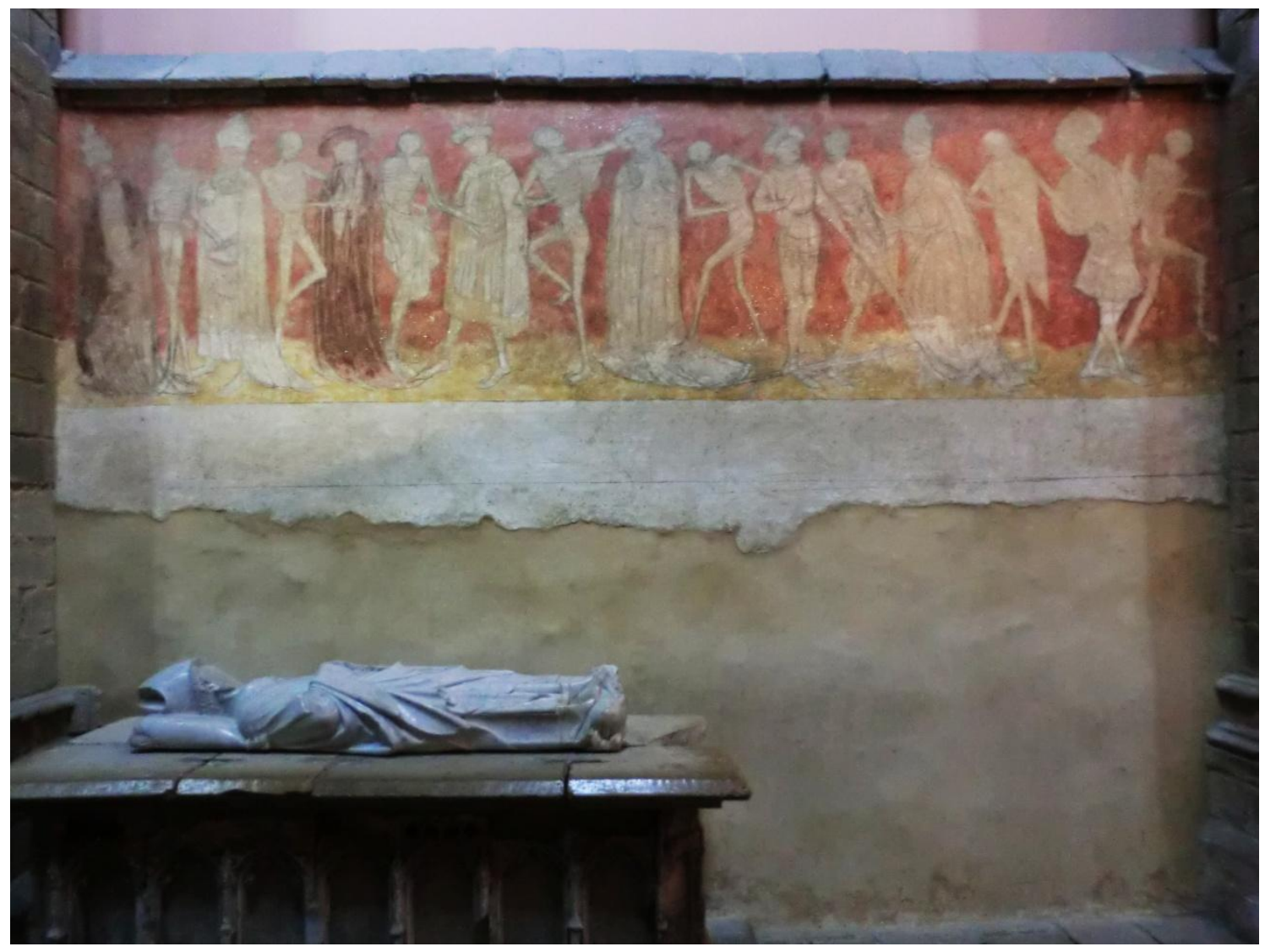

Figura 7: o primeiro painel, com os poderosos da sociedade (Papa, Imperador, Cardeal, Rei, religioso de alta hierarquia, Condestável, Bispo, Cavaleiro) acompanhados de seus respctivos transis.

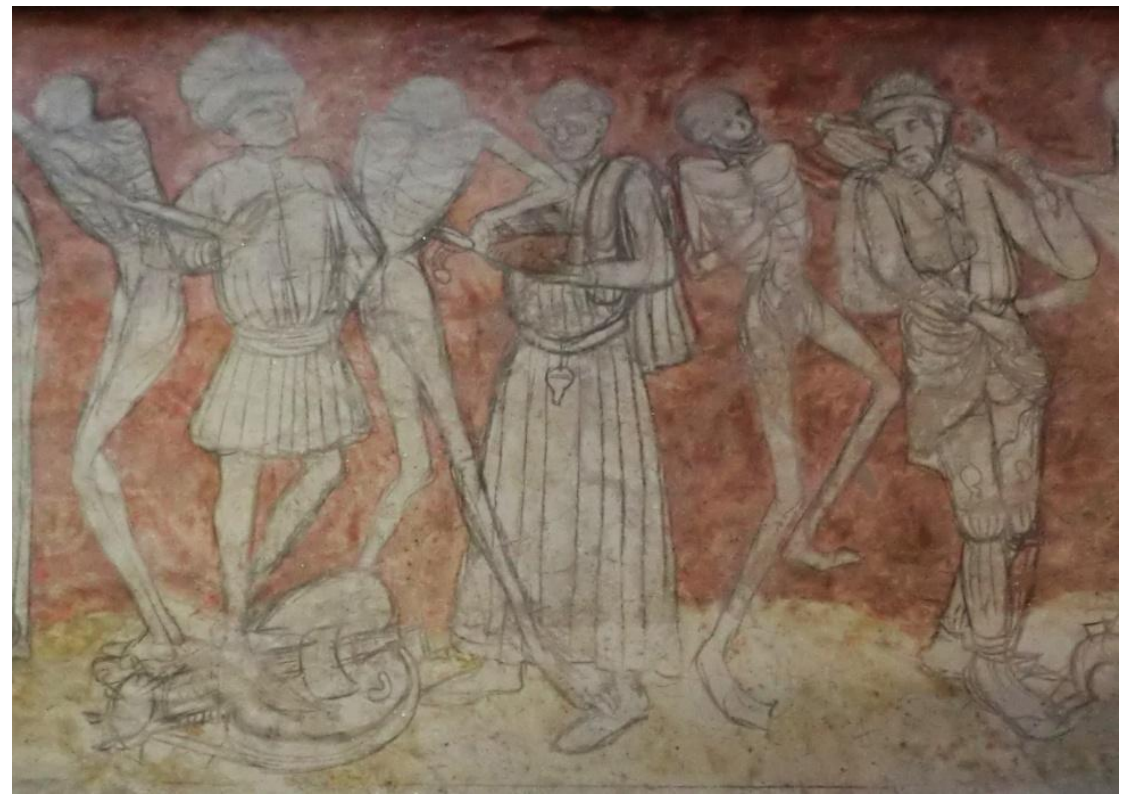

Figura 8: detalhe do terceiro painel, com os mais humildes da sociedade. Os três transis levam consigo o menestrel, o religioso estudante e o camponês. 
A pequena igreja românica de Meslay-le-Grenet, no departamento de Eure-etLoir, construída no século XII, também foi suporte para pinturas murais no final do século XV. As paredes, praticamente sem janelas do prédio simples de teto baixo, receberam diversos temas em voga no período: um "Encontro dos três mortos com os três vivos"; a "Lenda do Rei morto", as "Mulheres tagarelas na missa" (Les femmes bavardes à la messe) e uma Dança Macabra (figura 7), além de uma Paixão de Cristo atrás do altar. A dança de Meslay-le-Grenet também parece ter sido feita aos moldes do afresco parisiense; pela proximidade entre as duas cidades, é de se supor que repoduções chegaram aí rapidamente. Apesar disso, ela possui um elenco menor devido às dimensões diminutas do edifício - são 20 pares transi-vivo, no total (Papa, Imperador, Cardeal, Rei, Abade, Patriarca, Conetável, Arcebispo, Cavaleiro, Escudeiro do Rei, Abade, Meirinho, Sábio ou Astrólogo, Burguês, Cura, Médico, Lavrador, Criança, Usurário e Ermitão). Ao contrário da dança de La Chaise-Dieu, possui as estrofes em oito versos referentes à fala de cada personagem, ainda hoje bem visíveis todas as pinturas foram descobertas em 1864 e, possivelmente, restauradas. O poema é atribuído à Jean le Fèvre, mas não se comprovou sua autoria. O desfile é precedido da presença de um pregador. ${ }^{67}$ (figuras 9 e 10 )

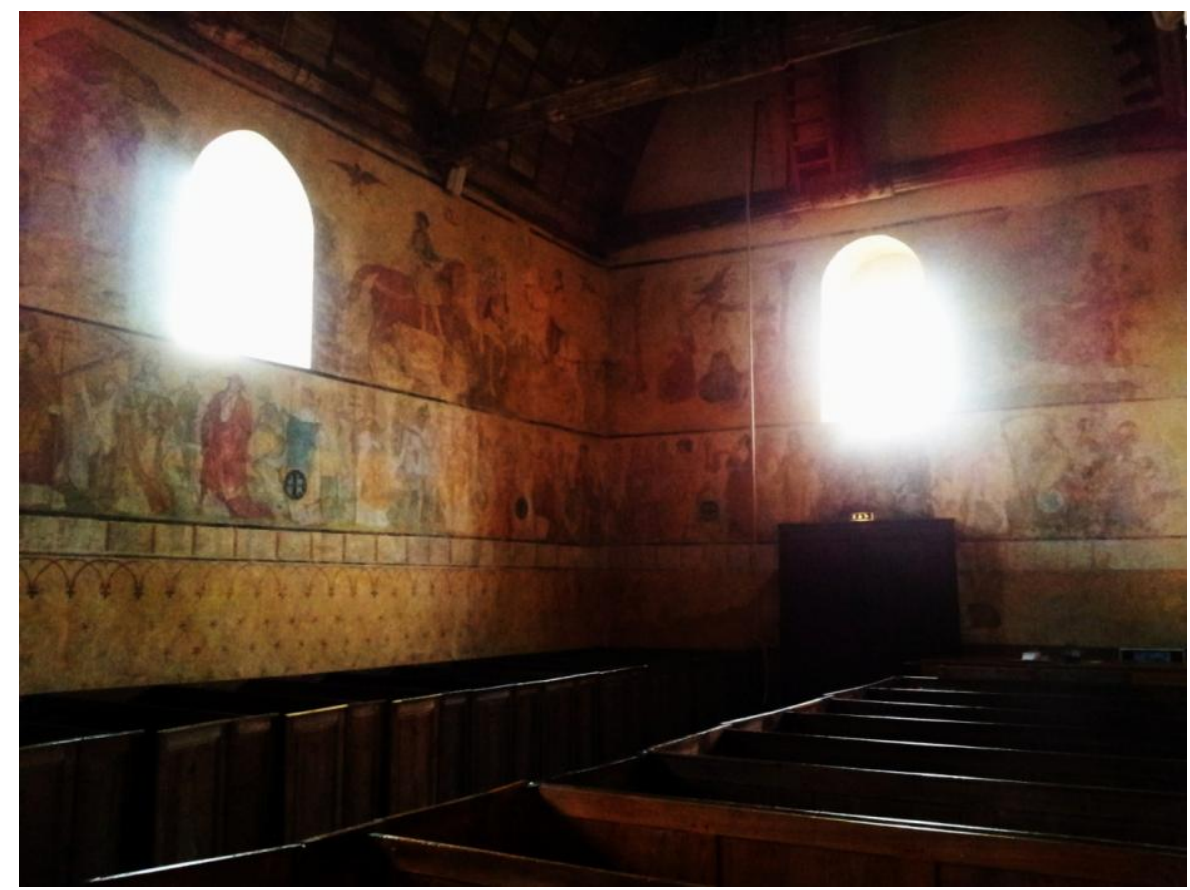

Figura 9: O lado sul da nave principal, com a dança macabra e os outros temas

\footnotetext{
${ }^{67}$ De acordo com André Corvisier, este seria um indício de que o afresco foi pintado após a publicação da dança macabra de Guyot Marchand, da qual se falará a seguir, que data de 1485 - e a dança de Meslay-leGrenet, de aproximadamente 1490-1500 (CORVISIER, 1969, p. 5).
} 


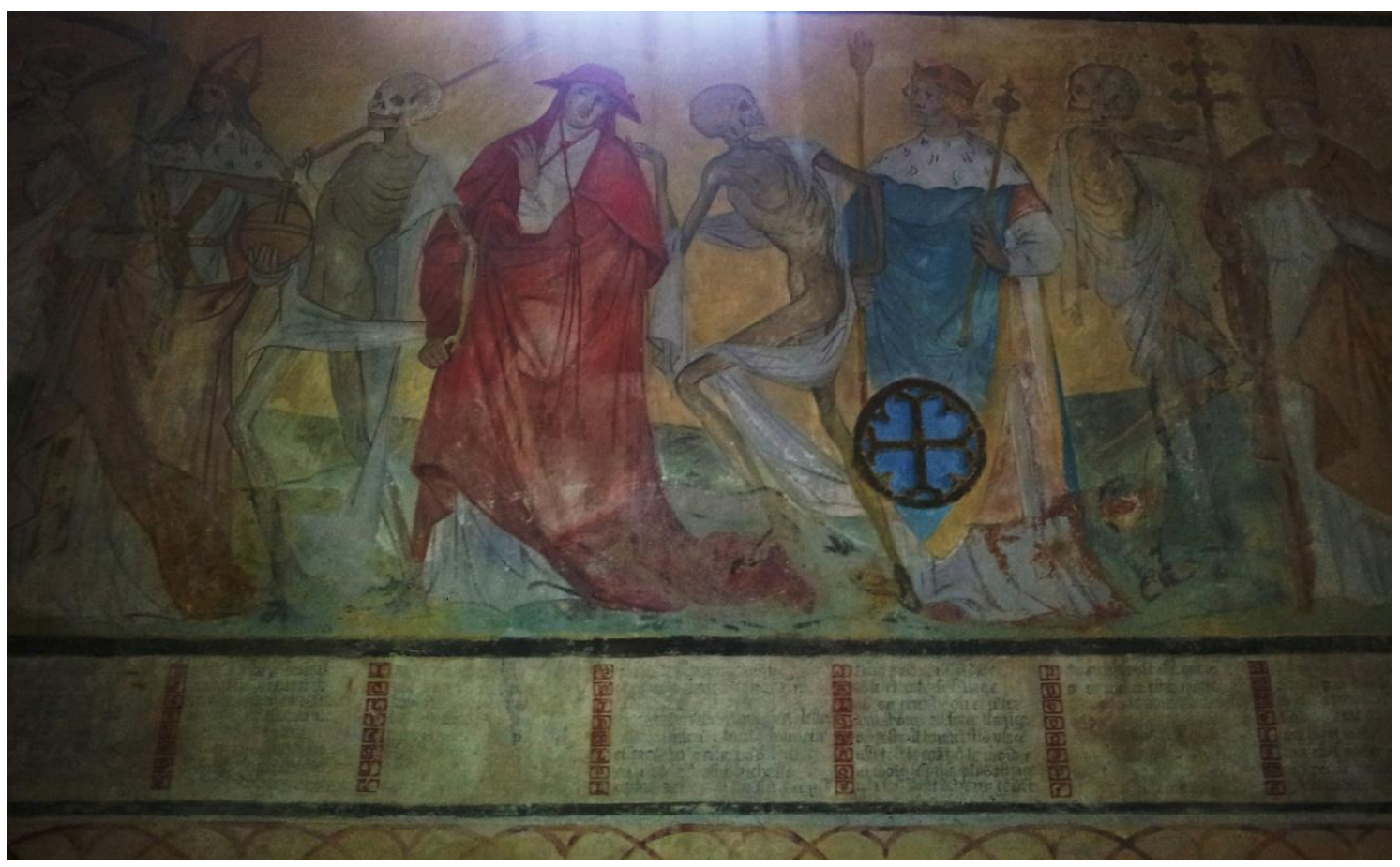

Figura 10: detalhe da dança de Meslay-le-Grenet: transis levando o Imperador, o Cardeal, o Rei e o Abade

A dança de Saints-Innocents foi também bastante reproduzida em versões impressas e gravuras que viajaram a Europa. A Biblioteca Nacional da França possui pelo menos 13 manuscritos de supostas cópias dos versos da Dança de Saints-Innocents. O mais antigo (Ms. fr. 25550 fol. 235) é anônimo e entitulado "Les vers de la danse macabre de Paris, tels qu'ils sont présentés au cimentière des Innocents", ${ }^{68}$ indicativo de que a expressão dança macabra já havia sido adotada. ${ }^{69} \mathrm{O}$ segundo, de 1425 , atribui ao poeta Jean Gerson a autoria dos versos e, a partir daí, surgiu a hipótese de que talvez ele fosse seu autor original. ${ }^{70}$ Esses textos passaram a ser impressos e vendidos na década de 1480.

Entre essas publicações, a mais famosa e provavelmente a maior responsável pela difusão do afresco parisiense, é um conjunto de xilogravuras acompanhadas de versos, publicado pelo editor parisiense Guyot Marchand em 1485. Acredita-se que seja um registro bastante fiel tanto do texto quanto da pintura, reproduzindo os mesmos personagens na mesma configuração. Apenas um exemplar desta edição foi conservado e encontra-se na Biblioteca Municipal de Grenoble. A "dança de Marchand”, como

\footnotetext{
${ }^{68}$ MÂLE, 1961, p. 141.

${ }^{69}$ Sobre isso, existe também o registro do Journal d'un bourgeois de Paris, citado na nota 56, acima.

${ }^{70}$ INFANTES, 1997, p. 164.
} 
passou a ser chamada, teve diversas edições nos anos seguintes - a primeira já no ano seguinte, aumentada em dez novos personagens, e acrescida da história do Encontro entre os três mortos e os três vivos, de uma Dança macabra das mulheres (de autoria de Martial d'Auvergne), e dos versos do Vado mori. Uma verdadeira "coletânea macabra" de grande sucesso comercial, o que comprova a força do tema à época. Tamanha repercussão gerou inúmeras cópias do modelo de Marchand, a mais famosa delas é a Danse Macabre a Paris, por Pierre Le Rouge, a mando de Antoine Vérard, editor parisiense, que as publica em 1491. Vê-se que as figuras são melhor elaboradas, com maior riqueza de detalhes, indicando pequenas alterações feitas pelos copistas. (figuras $14,15$ e 16$)$.

É principalmente por causa dessa versão de Guyot Marchand para a dança de Saints-Innocents, apoiada pelos registros manuscritos dos versos, que é possível elaborar um esboço daquela obra seminal. Tratava-se, então, de uma dança dos mortos e não da Morte. Um narrador-pregador abria os trabalhos, destacando o caráter universal e inevitável da morte: ${ }^{71}$

O creature raysonnable Qui desires vie eternelle. Tu as cy doctrine notable: Pour bien finer vie mortelle. La dance macabre sapelle: Que chascun a danser apprant. A homme et femme est naturelle, Mort nespargne petit ne grand.

Ele explica, em seguida, seu funcionamento: cada vivo, um morto faz avançar; e os primeiros a entrarem na dança são os "grandes" da sociedade:

En ce miroer chascun peut lire Qui le convient ainsi danser.

Saige est celuy qui bien si mire. Le mort le vif fait avancer. Tu vois les plus grand commancer Car il nest nul que mort ne fiere: Cest piteuse chose y panser. Tout est forgie dune matiere.

\footnotetext{
71 Todos os excertos provém da reprodução dos versos da Danse Macabre de Guyot Marchand em UTZINGER, 1996, p. 277-299.
} 
Na sequência, quatro cadáveres tocam seus instrumentos, cujo som dará ritmo ao desfile (figura 11). Eles também declamam seus versos. Ao leitor, que é também o espectador da cena, o primeiro morto adverte que todos, bons ou maus, participarão da dança um dia; seus corpos servirão de comida aos vermes, assim como o dele e de seus companheiros músicos:

Vous par divine sentence Qui vives en estatz divers Tous: danseres ceste danse Unefoys. et bons: et pervers. Et si seront manges de vers Voz corps. helas: regardez nous Mors. pourris. puans. descouvers Comme sommes: telx seres vous.

Um morto introduz o primeiro vivo a ser conduzido ao trespasse, a figura mais importante da cristandade: o papa (figura 12).

Le mort

Vous qui vivez: certainnement Quoy quil tarde ainsi danceres: Mais quant: dieu le scet seulement Advisez comme vous seres. Dam pape: vous commenceres Comme le plus dige seigneur: En ce point honore seres Aux grans Maistre est deu lonneur

Herdeiro da Igreja de São Pedro, o "deus na terra", nem mesmo o papa escapa à morte. Não só é necessário que ele acompanhe seu morto, como deve inaugurar a procissão:

Le pape

Hee: fault il que la dance mainne Le premier: qui suis dieu en terre Jay eu dignite souverainne En leglise comme saint pierre:

Et comme autre mort me vient querre Encore point morir ne cuidasse: Mais la mort atous maine guerre Peu vault honneur qui si tost passe 
A autoridade laica maior, o imperador, é o próximo da fila (figura 12). O morto ordena que ele abandone os acessórios símbolos de seu poder: o globo de ouro, o cetro, o selo (“Laisser fault la pomme dor ronde / Armes: ceptre: timbre: baniere”), pois ele já não governa nada. Este chega à conclusão que, apesar de sua hierarquia, os grandes nada têm de vantagem diante da morte ("Et morir me fault pour tout gage / Quest ce de mortel demainne / Les grands ne lont pas davantage”).

O mesmo se passa com o restante do elenco, que intercala leigos e cléricos, e é formado, após o imperador, pelo cardeal, o rei, o patriarca, o condestável, o arcebispo, o cavaleiro, o bispo, o escudeiro, o abade, o meirinho, o astrólogo, o burgomestre, o cônego, o comerciante, o cartuxo, o sargento, o monge, o usurário, o médico, o apaixonado, o cura, o lavrador, o advogado, o menestrel, o franciscano, a criança, o padre e o ermitão. Ao fim, os conselhos do "rei morto" àqueles que acompanharam o desfile ("Vous: qui en ceste portraiture / Venez danser estas divers / Pensez que humaine nature: / Ce nest fors que viande a vers"), lembrando que tudo na terra é transitório (“cest tout vent: chose transitoire”), e, sendo a morte certa, é necessário "mener vie humble et religieuse".

Cada figura era sempre acompanhada de seu morto. Abaixo da gravura, as 2 estrofes em 8 versos octossilábicos, a primeira com a convocação do cadáver, a segunda com a resposta ao chamamento (figura 13). Contabilizam, ao final, 92 estrofes. Dessas, chama a atenção as palavras proferidas por um dos últimos personagens, a criança. Ela sequer aprendeu a falar, apenas balbucia; é recém-nascida ainda, mas evoca a mais pungente lição das danças: ninguém está imune à morte.

\section{Lenfant}

A. a. a. ie ne scay parler

Enfant suis: iay la langue mue.

Hier nacquis: huy men fault aller

Ie ne faiz que entrée et yssue.

Rien nay mesfait. mais de peur sue

Prendre en gre me fault cest le mieulx

Londenance dieu ne se mue.

Ainsi tost meurt ieune que vieulx. 
9os en bichominis fempercum tempore labi: Et femper quabam conoicio

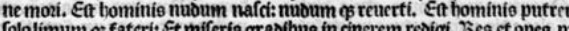

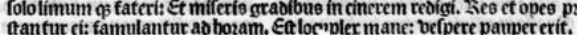

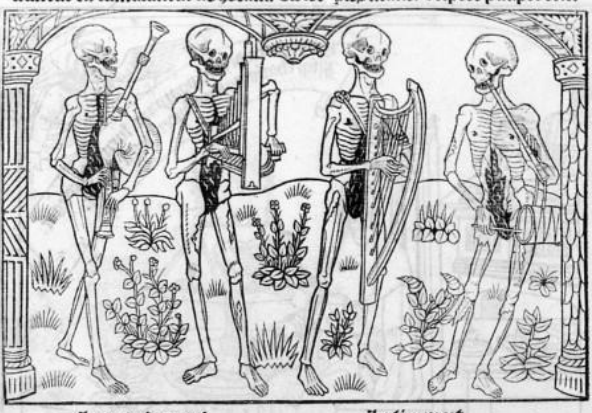

Zous 2e premier mort

Qui vines en ettat 3 ofuers

Eous: Danferces cefte danfe

Encfops, et bons:et peruere.

- 03 corps. belas: regaroes nous

Sors, pourtis, puane, offerounerf

comme fommeg:telr feres

Dictez nous par quelles raifons

Fous ne pentes point a mozic

Gutla

Gans quonvouns puiffe fecourix

Eeft maloiure: fans p penfer

Et troup grant oanger oe perí.

force et quil faille ainfioanfer.

Le tier mort
Entenoesce: que í vous oig Entendezce: que ie vous ois.
Feunes et vieurr: petis et grans

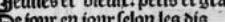

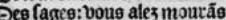
ar vos iours vont siminuang Sour quop: tous ferez trefpaffes Eeulrqui viues: oeuät cent angi Las:cent ans feront toft paffes. Lequart mort Eevất quil foient cent ans paffé Eous les viuans comme trits Enemfer:ouen ferout paradis Don compaanon: mais ie te ois. Dev de crent font qui aient cure Des treipateo:ne de nos dis. Le fait oeulr: giten: aouéture.

Figura 11: os cadáveres- músicos

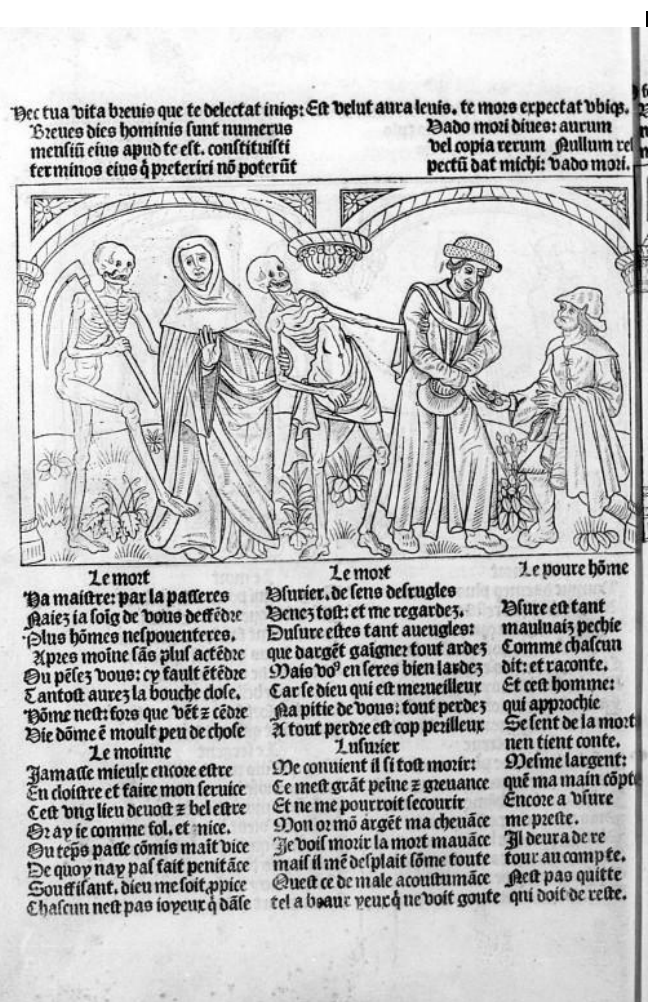

Figura 13: o monge, o usurário e o pobre.

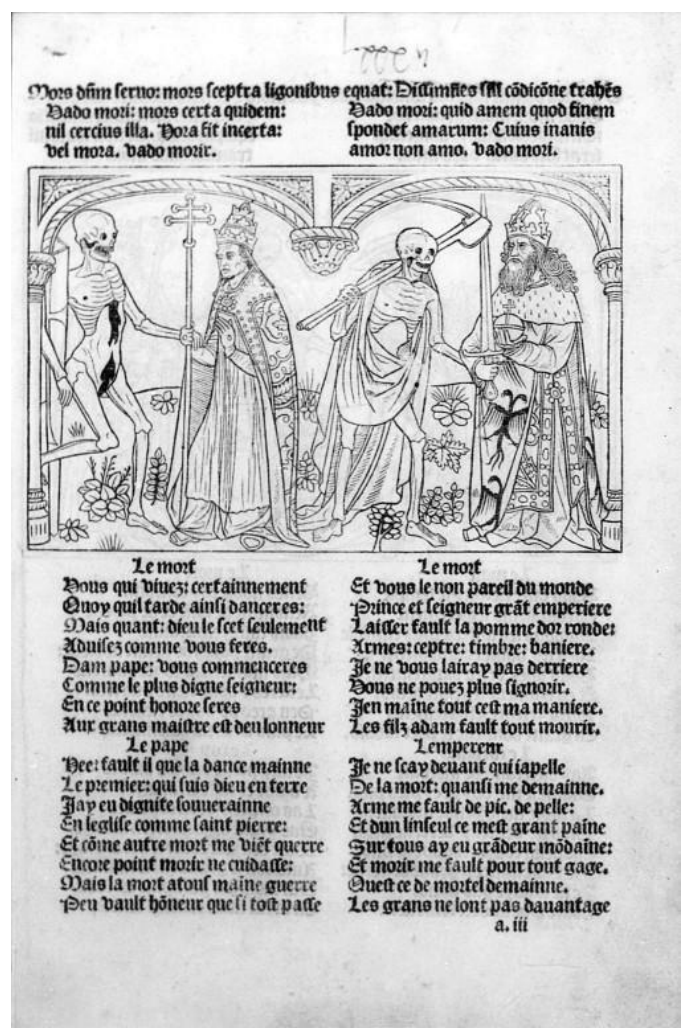

Figura 12: o Papa e o Imperador

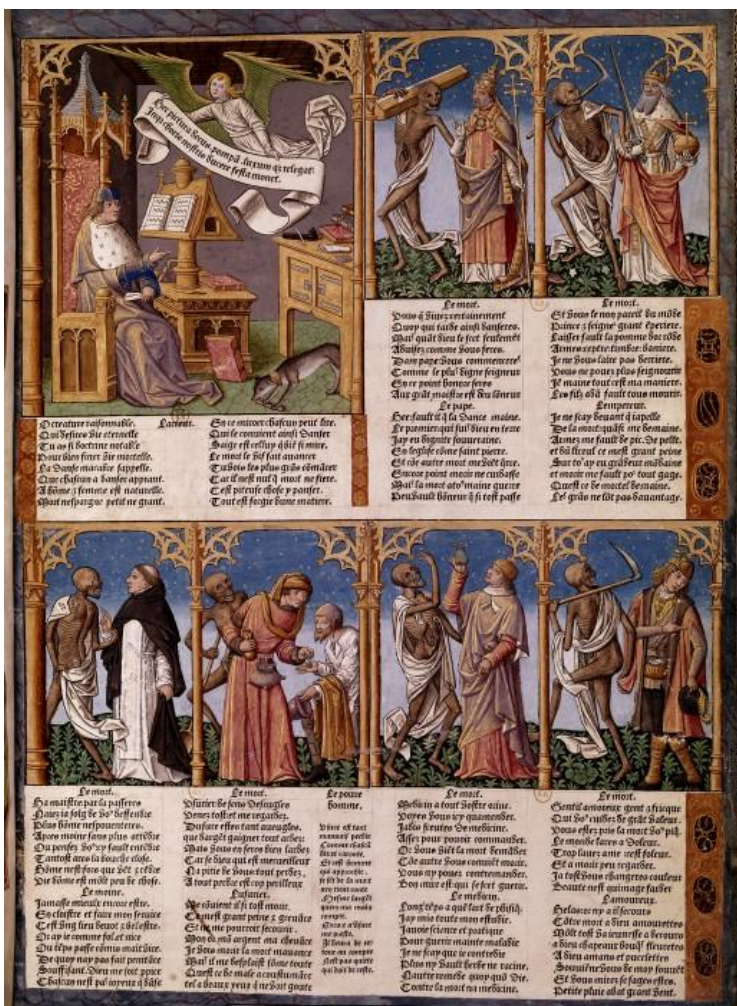

Figura 14 


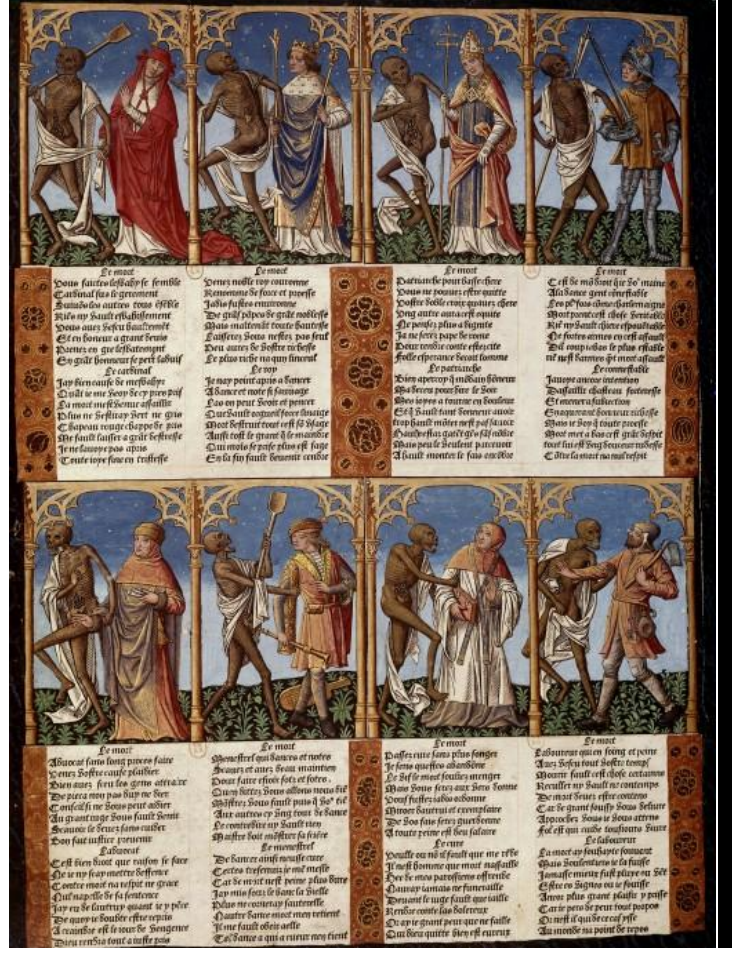

Figura 15

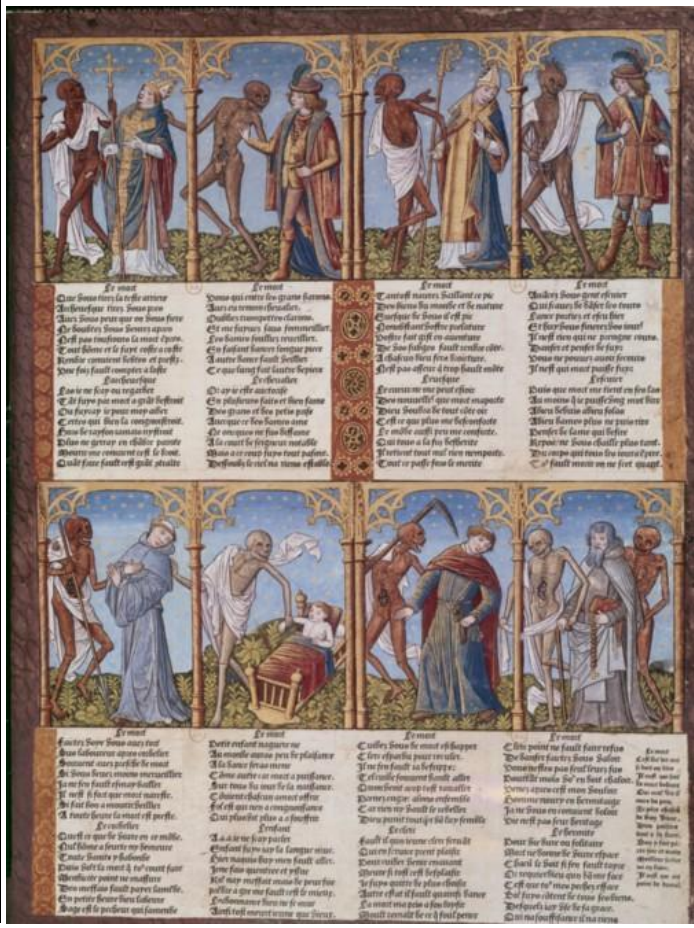

Figura 16

Com a publicação por Marchand dos supostos versos e personagens da dança original de Saints-Innocets, o gênero ganha um modelo, um formato razoavelmente padronizado que foi replicado em diferentes suportes (manuscritos, afrescos, gravuras, esculturas) e difundido por toda Europa Ocidental no final do século XV e no decorrer do século XVI. Levantamentos ${ }^{72}$ apontam que a Alemanha é o território que possui o maior número de exemplares documentados (pelo menos 36). A França vem na sequência, com cerca de 28. Onze danças são italianas, doze provêm da Suiça, 5 da Austria. Na Inglaterra são também 5, enquanto que na Grã-Bretanha, por volta de 14. Quatro danças, apenas de textos, são espanholas. A Polônia, a Dinamarca, a Estônia e a Finlândia participam desta lista contando com 1 ou 2 danças, cada. Destes exemplares, alguns tornaram-se popularíssimos, devido ao grande impacto que causaram à época, ajudando a disseminar a cultura do macabro. Infelizmente, grande parte desse inventário já não existe mais ou encontra-se bastante degradada.

Certos documentos nos ajudam a refletir sobre a passagem do poema de Le Fèvre para essa nova configuração, tão particular, das Danças. Um deles é o manuscrito

\footnotetext{
${ }^{72}$ As referências, aqui, são a lista de Utzinger (1996), de Infantes (1998) e de Corvisier (1998). Os números finais são aproximados.
} 
encontrado na cidade de Wurzbourg, escrito por Sigismund Gossembrot, alocado em uma coletânea de textos produzidos entre 1443 e 1447, chamada Codex Palaticum Germanicum, depositado na Biblioteca Universitária de Heidelberg (Cod. pal. germ. 314, fol 79-80). Apesar de sua data aproximada de confecção, acredita-se que ele seja, na verdade, uma versão ou transcrição de um texto mais antigo, do qual quase nada se sabe. O manuscrito de Wurzbourg seria responsável pela linhagem em línguas germânicas das Danças.

Sua narrativa dispõe 24 personagens de variadas condições sociais (papa, imperador, imperatriz, rei, cardeal, patriarca, arcebispo, duque, bispo, condestável, abade, cavaleiro, jurista, cônego, médico, nobre, nobre dama, comerciante, freira, mendicante, cozinheiro, camponês, criança e mãe) que dialogam com os mortos que chegam para buscá-los. Seria, na verdade, um tipo de mescla entre o Vado Mori (devido à sua estrutura de estrofes de dois versos) com a Lamentatio (na qual a fala dos personagens é direcionada a alguém), mas com a presença dos mortos como interlocutores - apesar destes nunca contestarem. A fala de um pregador abre o texto.

Um dos versos ("Hec ut pictura docet exemplique figura”) pode sugerir uma referência às danças iconoráficas, ainda que não se saiba exatamente qual (se uma específica, ou se ao próprio gênero, em geral). Se for o caso, é possível supor que o manuscrito seja posterior às primeiras danças macabras documentadas, isto é, após 1424. Sabe-se que o manuscrito foi publicado diversas vezes e em apenas 2 edições foram acrescentadas xilogravuras (uma de meados do século, outra de cerca de 1480). ${ }^{73}$

A mesma polêmica a respeito da datação correta ocorreu com a Danza General de la Muerte, manuscrito em castelhano antigo, doado à Biblioteca do Mosteiro El Escorial, em Madrid, no ano de 1576 (Ms. b.IV.21, fol. 109-129). Não há informação alguma sobre sua procedência, autoria ou data de composição, que se estima por volta de 1440-1450. No entanto, existem fortes indícios de que se trata de uma transcrição, pois lê-se em sua primeira linha: "Dança general. Prologo enla trasladaçion”, o que pressupõe que este manuscrito não passe de uma tradução ou de uma cópia de um outro original, do qual não se têm notícias. Os pesquisadores não chegam a um consenso em

\footnotetext{
${ }^{73}$ WETZEL In: Danse macabre, 2011, p. 28.
} 
relação a esse suposto texto original mas, se ele existiu, presumem que seja dos últimos anos do século XIV ou dos primeiros do século XV. ${ }^{74}$

A Dança general é excepcional no sentido de ser uma das raras danças apenas literária, sem qualquer tipo de iluminura ou ilustração. Além do texto de apresentação, em prosa, na primeira página, tem 79 estrofes de 8 versos dodecassilábicos. Trata-se de uma dança da Morte e não dos mortos. O esquema é o de praxe nas obras do gênero: a Morte convida um personagem para entrar na dança, este, surpreso, tenta se esquivar e argumentar. Na estrofe seguinte, ela critica seu comportamento e assinala ser esse seu momento derradeiro; no último verso, intima o próximo da fila. Seus 33 personagens, intercalados entre laicos e religiosos, indicam os tipos mais representativos da sociedade medieval - como de costume nas Danças. Entre eles, está o Papa, primeiro a ser convocado, guia para os outros. Seu poder incomparável não o livra da morte; deve livrar-se de sua capa e começar a saltar ao ritmo da dnaça, sem mais demoras:

E porque el Santo Padre es muy alto señor, y en todo el mundo non hay su par que desta mi danza será guiador, desnude su capa, comience a sotar; non es ya tiempo de perdones dar, nin de celebrar en grande aparato, que yo le daré en breve mal rato: danzad, Padre Santo, sin más detardar.

\footnotetext{
${ }^{74}$ Inúmeras teorias foram construídas neste sentido, como por exemplo, a de Victor Infantes. Para este autor, no caso de haver um texto original, a única informação sobre ele estaria contida na ordem dos documentos dada pelo compilador da miscelânea, que teria unido textos de um mesmo período, obedecendo um sentido cronológico. Assim, seria possível presumir que o texto original pertenceria à segunda metade do século XIV, provavelmente das últimas décadas, próximo de 1400. No entanto, segundo Solá-Solé, há um outro dado a ser considerado: a presença de um personagem denominado "rabino Açá", que o pesquisador identifica como sendo Yishaq ben Seset Perfet (1326-1408), perseguido pelo pogrom de 1391, causando grande comoção da comunidade judaica. Na última década do século $\mathrm{XIV}$, o nome do rabino seria, por isso, bastante popular, o que teria influenciado o autor da dança a incluílo entre os personagens - resultando, assim, na estimativa de sua produção como sendo desses anos. Para James Clark e Hurtado e Cvitanovic o texto era a tradução de um texto francês, sem, no entanto, fornecer maiores provas desta teoria. (Ver em: SOLÁ-SOLÉ, 1981; HURTADO y CVITANOVIC, 1966; CLARK, 1947; INFANTES, 1997.)
} 
Apesar de todas as honras e benefícios que goza, o Papa admite por fim que nem ele poderia escapar à morte. Depois de se queixar, evoca Jesus e a Virgem no instante derradeiro:

Dice el Padre Santo

¡Ay de mí, triste, qué cosa tan fuerte! a yo, que tractaba con grand prelacía, haber de pasar agora la muerte y non me valer lo que dar solía. beneficios y honras y grand señoria tuve en el mundo, pensando vivir; pues de ti, muerte, non puedo fuir. valme Iesucristo, y tu, Virgem Maria.

$\mathrm{Na}$ estrofe seguinte, a Morte faz pouco caso das lamúrias do Papa (“Non vos enojedes, señor Padre Santo, de andar em mi danza”) que deve ir sem mais protestos (“aquí moriredes sin ser más bollícios”). No último verso, ordena a presença do Imperador em seu baile, e que este esteja com expressão contente (“¡Danzad, Imperante, con cara pagada!'”)! O Imperador, apavorado, não compreende de imediato quem o obriga a dançar contra sua vontade. Reconhece a Morte, contra a qual ninguém pode se defender, homem grande ou coitado, rei ou duque. Neste momento, pede por socorro mas é tarde: já sente-se confuso, com a consciência alterada.

Dice el Emperador

¿Qué cosa es esta que tan sin pavor me lleva a sua danza a fuerza, sin grado? Creo que es la muerte, que non ha dolor de hombre que sea grande o cuitado, non hay ningun rey nin duque esforzado, que della me pueda ahora defender: ¡acorredme todos! mas non puede ser, que yo tengo della todo el seso turbado.

Mesmo sendo uma figura muy grande e poderosa no mundo, que a tudo governou com grande tirania, a Morte recomenda ao Imperador que não mais se preocupe pois não há mais tempo para tal: ninguem ou nada pode livrá-lo. Ao término da estrofe, chama o próximo da fila, o cardeal. 
Dice la muerte

Emperador muy grande, en el mundo potente, non vos cuitedes, ca non es tiempo tal que librar vos pueda imperio nin gente, oro nin plata, nin otro metal; aquí perderedes el vuestro cabdal, que atesorastes con grand tirania, haciendo batallas de noche y de día. morid, non curedes. ¡Venga el cardenal! $(\ldots)$

Com a única exceção do monge, que declara "muerte, non me espanto de tu fealdad", todos os outros personagens temem a Morte e lamentam o encontro abrupto com ela. O arcebispo exclama: “'Ay muerte cruel! ¿Qué te merecí,/ o por qué me llevas tan arrebatado? viviendo en deleites, nunca te temí;/ fiando en la vida, quedé engañado.". O duque pede mais tempo (“espérame un poco, muerte, yo te ruego"); o bispo chora de tristeza ("Mis manos aprieto, de mis ojos lloro,/porque soy venido a tanta tristura”). O cavaleiro pondera: a ele não parece apropriado largar suas armas para dançar (“A mí non parece ser cosa guisada / que deje mis armas y vaya danzar”). Mesmo na hora de morrer, a principal preocupação do comerciante é com seus negócios (“'A quién dejaré todas mis riquezas / y mercadurías que traigo en la mar?”), assim como o usurário ("Non quiero tu danza nin tu canto negro,/mas quiero, prestando, doblar mi moneda"). O lavrador humilde nem sabe como reagir ao chamado - ele, que nunca tirou as mãos do arado (“¿Cómo conviene danzar al villano / que nunca la mano sacó de la reja?”).

Mas a Morte na Danza general aparece como senhora absoluta do destino da humanidade. Não é piedosa, usa armas e armadilhas, e em inúmeras passagens do poema, chega mesmo a ser fria e direta quanto à sorte de suas vítimas, parecendo negar, em alguns momentos, a idéia cristã do trespasse, do passamento. Na obra, ela é castigo (“esto vos ganó vuestra madre Eva /por querer gostar fructa devedada”); sua dança não é prazeirosa, é, antes, denominada "danza mortal" (verso 57), "danza baja” (verso 138), "danza sin piadad" (verso 153), "danza negra" (verso 235), "danza de dolores" (verso 268). Ainda assim, ela é sarcástica e exige constantemente que seus convidados dancem com animação e com a feição alegre. Nenhuma circunstância permite livrar-se dela: nem o poder temporal do rei, nem o poder religioso do papa, ainda menos o 
dinheiro do burguês - "Yo soy la muerte cierta a todas criaturas", anuncia em seu primeiro verso. Tampouco a idade serve de excusa - do ancião ao jovem, todos são levados. Diante dela, a nostalgia, a resignação e o medo são sentimentos comuns, que igualam os homens. Tanto é que, ao final, ela se remete a todos aqueles que ainda não entraram em sua dança, mas que o farão quando menos esperarem: que respondam ao chamado prontamente, sem delongas, :

Lo que dice la muerte a los que non nombró

A todos los que aquí non he nombrado, de cualquier ley y estado o condición, les mando que vengan muy toste priado a entrar em mi danza sin excusación.

A caracterização da Morte personificada é sui generis na Dança espanhola e merece comentário. Além de portar objetos diversos como "lazos", "redes", "arco", "frecha", "charanbela" e "bozina", e de ter "mano dura" e "duros dientes", tem uma aparência terrível, é "cruel" e "muy braba". Com astúcia, chega repentinamente, às vezes "sin facer ruído". Presenteia suas vítimas com "bubas y landres"; estas ficam com o "seso turbado", pois sua chegada é "cosa muy fuerte"; um "pierde el entendimiento", outro se torna cego, a muitos falham os sentidos.

A Danza general originou outros manuscritos, entre eles uma dança impressa em Sevilha, em 1520, depositado na Biblioteca de Alexandria. Seu texto, é similar ao texto da primeira, com a diferença de ter mais 23 personagens e consequentemente, ser mais longo (as 79 estrofes se convertem em 139). A Dança Sevillana, como passou a ser chamada, refletiria, portanto, uma sociedade urbana que, em menos de um século, se tornou ainda mais complexa, contando com novos e representativos tipos sociais que sequer foram mencionados no texto anterior.

Decerto, mais do que os textos, a produção de afrescos e depois de gravuras, foram responsáveis pela expansão do tema para toda a Europa Ocidental. Os primeiros pelo seu aspecto público, uma vez que as pinturas ficavam expostas em locais de grande circulação, como em igrejas ou cemitérios. No caso das gravuras, pelo alcance que 
tinham essas reproduções que circulavam e viajavam pela cristandade, fosse nas mãos de curiosos, fosse com os clérigos pregadores que as utilizavam em suas peregrinações. Mas essa passagem das danças como pinturas murais para as danças impressas exigiu uma mudança em sua estrutura. Pela dificuldade em manter a configuração de desfile ou ciranda dos afrescos em que todos os personagens se tocam, eles agora são divididos em suas duplas de morto-e-vivo e cada uma, ocupando uma página da publicação. Sobre o par, as duas estrofes do poema nas quais o cadáver chama sua vítima e esta responde. Ao retirar cada vivo da roda e isolá-lo com seu morto, sua própria projeção, o novo suporte permitiria uma leitura mais individualizada do evento da morte.

\section{Ars Moriendi, Livros de horas e Truinfos da Morte}

Essa mesma característica encontra-se em um outro gênero iconográfico bastante difundido no fim da Idade Média, os Ars Moriendi. Tratam-se das representações do momento da morte que se passam no quarto do moribundo. São ensinamentos sobre a "arte de bem morrer", quer dizer, como conduzir o próprio óbito para o caminho correto, buscando uma morte piedosa, edificante, que visa a ascensão ao paraíso. Seu caráter novedoso se dá por enfatizar a ação individual, como o arrependimento, nos últimos momentos da vida. Ao redor do leito, anjos e demônios disputam a alma do agonizante, mas o destino de sua alma depende de suas decisões.

Os Ars Moriendi foram muito populares entre os séculos e XV e XVI, principalmente no formato de gravuras impressas. Sua origem é incerta; acredita-se que sejam inspirados em um tratado do poeta Jean Gerson chamado De arte moriendi, de cerca de 1403. A primeira que se tem registro data de 1465, proveniente da Colônia. Na França e na Alemanha, sua aparição data da primeira metade do século XV, e nos Países Baixos, e depois na Inglaterratra e na Espanha, por volta de 1480. Até o fim do século se disseminaram na Inglaterra e na Itália. ${ }^{75}$ Ainda que as imagens do macabro não fossem fundamentais para as mensagens dos Ars Moriendi, poderiam aparecer cadáveres ao lado do moribundo (sua imagem futura), ou ainda, transis representando a

\footnotetext{
${ }^{75}$ CORVISIER, 1998, p 48.
} 
chegada da morte - como no caso da tela A morte do avarento, de Hieronymus Bosch (1490-1500), em exposição na National Gallery of Art, em Washington (figura 17).

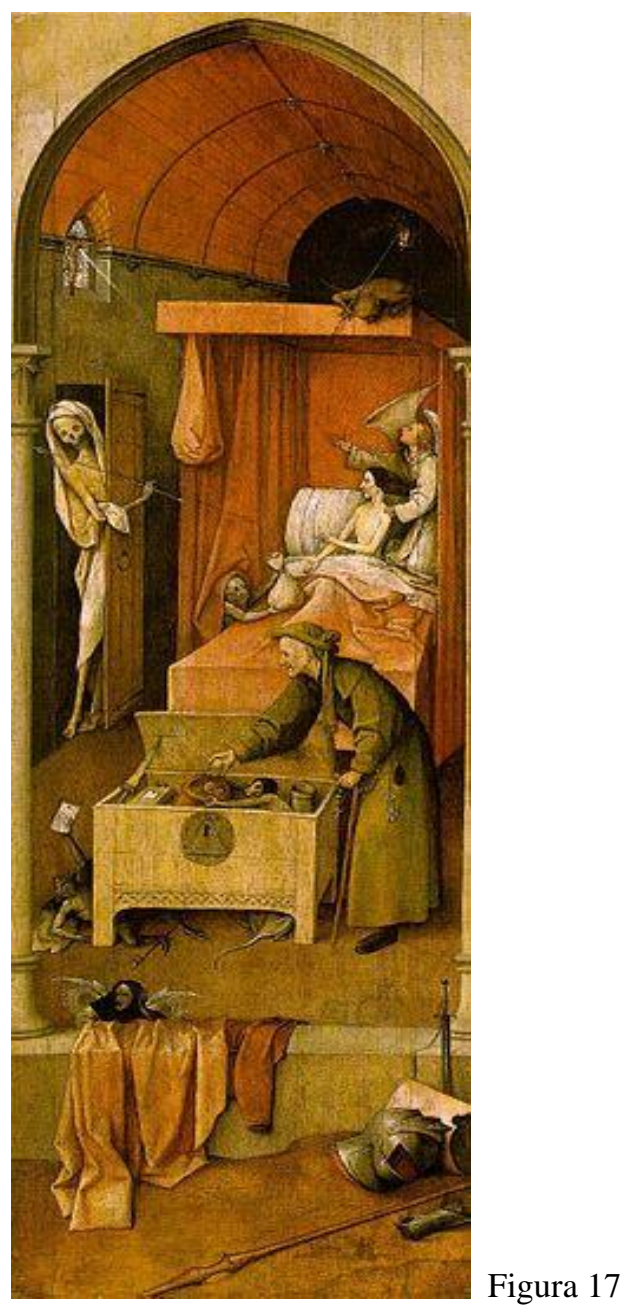

O mesmo ocorria com os Livros de Horas. Considerados dos mais importantes documentos manuscritos deixados pela Idade Média Tardia para o estudo da vida privada na época, eram “essencialmente livros pessoais de orações encomendados por aristocratas leigos e produzidospara eles pelos melhores caligrafos e iluminadores. "76 Sua função era fornecer textos litúrgicos e preces apropriadas para cada hora canônica do dia ou evento do cotidiano. A produção de livros de horas se torna mais profícua a partir do fim do século XV, principalmente nas cortes francesa e borgonhesa e avança no século seguinte, fazendo parte da cultura material dessas elites.

\footnotetext{
${ }^{76}$ HARTHAM, J. Verbete Livros de horas. In: LOYN, 1997, p. 238.
} 
Ricamente decorados por miniaturas e iluminuras, incorporaram gradativamente a iconografia macabra nos ofícios para os mortos, com ilustrações inspiradas nos Ars Moriendi, no Encontro dos três mortos com os três vivos e nas Danças. Michel Vovelle confirma esse processo com base nos exemplares depositados na Biblioteca Nacional de Paris, nos quais analisou cerca de 280 imagens de ofícios de mortos: as representações da decomposição física ou de cadáveres (transis, deitados ou mortos de maneira violenta) limitam-se no século XIV a menos de 5\%; aumentando constantemente até chegarem a um quarto no começo dos setecentos. As Très riches heures du Duc du Berry e o livro de horas da família Rohan são edições particularmente conhecidas por seu bom estado de conservação. Ambos são de aproximadamente 1410-1415 ${ }^{77}$ e contam com cenas do repertório macabro (figura 18 e 19).
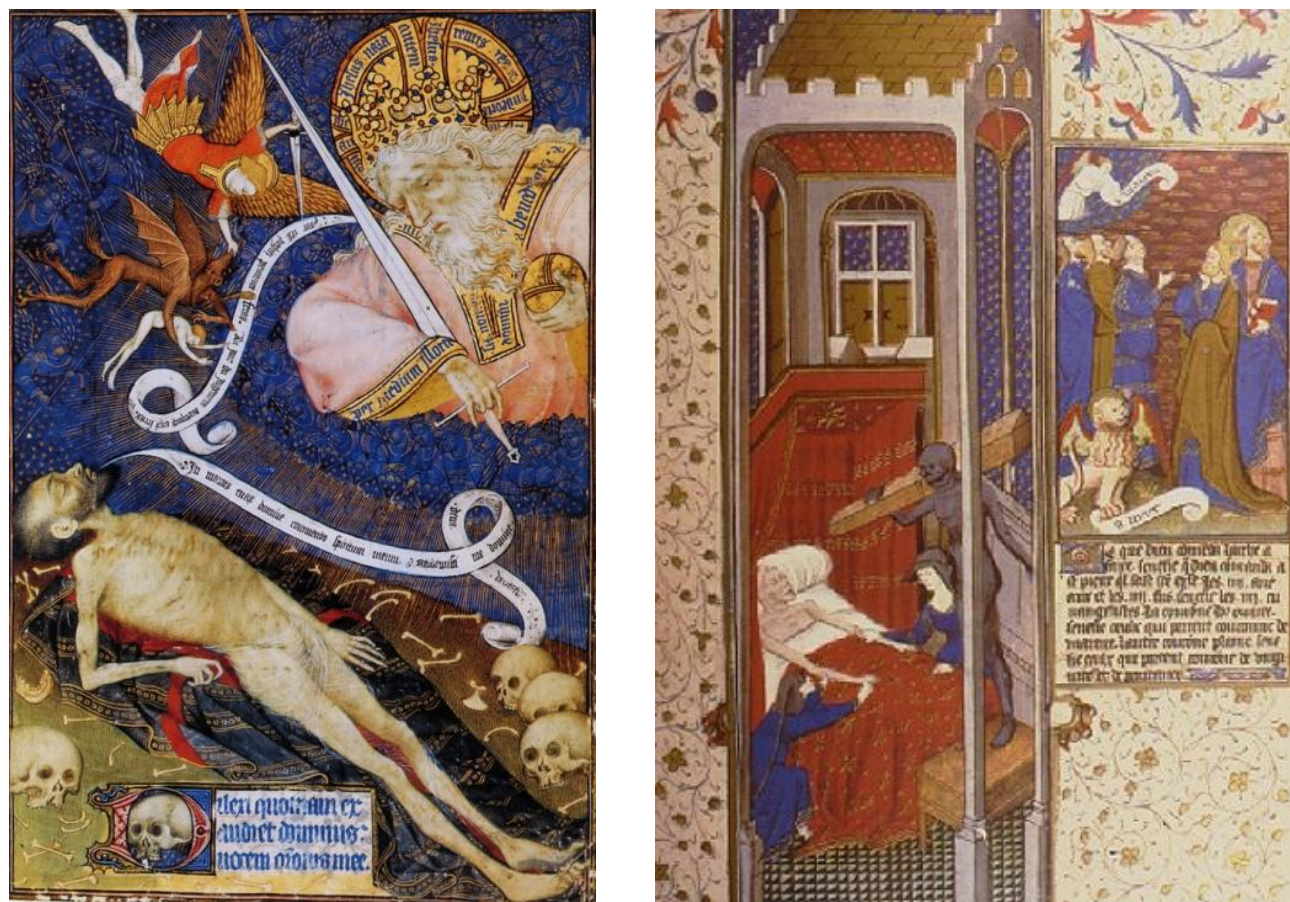

Figuras 18 e 19: O dia do Juízo e o ofício dos mortos do Livro de horas da família Rohan.

O caso dos Triunfos da Morte é notadamente especial no percurso até aqui traçado sobre o macabro medieval pois ele antecede a imagem da morte que prevaleceria nos séculos modernos: a da morte personificada, ou melhor, a "Morte", e não mais "os mortos". Assume-se, agora, sua identidade feminina, dada pelo gênero da palavra morte nas línguas latinas. Suas raízes estão nos Versos da Morte, de Froidmont, na Dança Macabra, notadamente em sua linhagem espanhola, e no poema Il Trionfo della Morte, de Petrarca (publicado entre entre 1351 e 1374). Neste, a Morte é uma

\footnotetext{
${ }^{77}$ MÂLE, 1961, p. 137.
} 
"insegna oscura e trista" (verso 30), uma dama vestida de negro ("una donna involta in veste negra" [verso 31]) que a todos extirpa com sua espada.

Io ho condotto al fin la gente greca e la troiana, a l'ultimo I Romani, con la mia spada la qual punge e seca, e popoli altri barbareschi e strani; e giugnendo quand'altri non m'aspetta, ho interrotti mille penser vani. Or a voi, quando il viver più diletta, drizzo il mio corso inanzi che Fortuna nel vostro dolce qualche amaro metta.

Essa representação da grande ceifadora, detentora gloriosa do destino do mundo, é a que vigora na iconografia do Triunfo da Morte. Mas a personagem toda-poderosa, quando feita imagem, revela sua ascendência macabra: a dama de preto à maneira petrarquista é substituída pelo transi dessecado, ou ainda, pelo esqueleto, que prevalece nos exemplares do gênero. Entre 1450 e 1550, o tema obteve um inquestionável sucesso, não somente na Itália, onde surgiu e foi enormemente explorado, mas também em França. Ele se espalha por Alemanha e Espanha principalmente através de gravuras e iluminuras. $^{78}$

Nos afrescos, forma em que obteve maior repercussão, os Triunfos mostram uma morte impiedosa, que provoca verdadeiros massacres. Os exemplares mais significativos desse conjunto talvez sejam o do Camposanto, de Pisa, uma monumental pintura mural de meados do século XIV, cuja autoria é atribuída à Buonamico Buffalmac, e o do Palazzo Abbatelli, em Palermo, de pintor anônimo, do século XV (figura 20). Nelas, a Morte está montada à cavalo, um tipo de convenção que emerge como um padrão às obras do gênero, emulando o imaginário do cavaleiro do Apocalipse. Assim, ela é replicada no mais famoso exemplar de Triunfo da Morte, a tela de Pieter Brueguel, de 1562, em exposição no Museo del Prado, Madrid.

\footnotetext{
${ }^{78}$ VOVELLE, 1983, p. 123.
} 


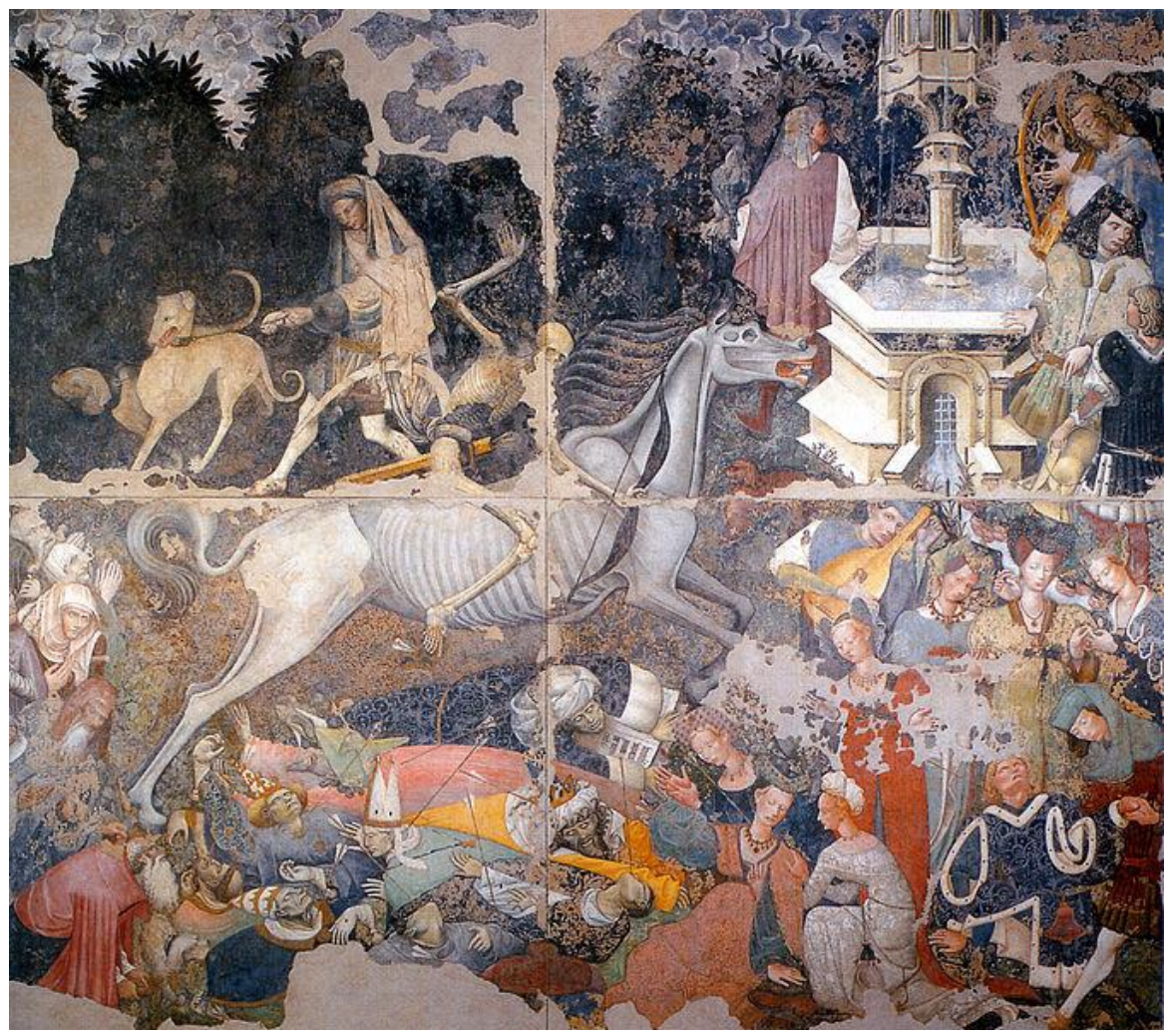

Figura 20

\section{O macabro na poesia}

Enquanto o Encontro e as Danças (e, por extensão, as Ars Moriendi, os Triunfos da Morte e os Livros de horas) ajudavam a tornar o macabro visível e imagético, havia ainda uma produção poética que falava dessa mesma exposição ostensiva da decomposição do corpo. Pierre de Nesson (1383 - ca. 1442) foi particularmente significativo nessa leva de obras que exaltam a carniça e a podredume em um poema que, originalmente, não tinha título, mas cujas versões posteriores trataram de denominá-lo Neuf leçons de Job e, mais tarde, Vigiles des morts (o manuscrito mais antigo encontra-se na Biblioteca Nacional da França [Ms. fr. 578 fol. 122-130]). ${ }^{79} \mathrm{O}$ autor enumera nove lições retiradas, por sua livre interpretação, do Livro de Jó e, em seguida, reflete sobre elas, em versos notadamente macabros. Para ele, o homem está fadado a apodrecer desde que nasce ("Tu nais et puis tu te norris; / Tu vis puis muers et puis porris; / Et, apres ce, tu n'es mes rien.") e, ao contrário da natureza que oferece

\footnotetext{
${ }^{79}$ CHAMPION, 1923, p. 198.
} 
flores perfumadas e frutos que alimentam, o homem não é mais que secreção, fedor, corrupção:

Helas! quant les arbres fleurissent! Deux belles odorans fleurs yssent, Et fruit savoureux qu'on mengue: Mais de toy n'ist que toute ordure, Morveaulx, crachas et pourriture, Fiante puant et corrumpue!

A morte não é alívio; pelo contrário, é dolorosa, pois após o trespasse, só resta ao corpo decompor-se e, por isso, não há para ele lugar nesse mundo - dejeto repugnante, ele infecte o ar, a água:

Et lors, quant tu trespasseras, Des le jour que mort tu seras, Ton orde char commencera A rendre pugnaise pueur. Que ne goutes tu de suer Quant tu penses que ce sera?

Car qui en l'air te laisseroit? Incontinent infect seroit; En l'eau ne te mettra l'en pas: Car ton orde char fault qu'il pue, $\mathrm{Si}$ on feroit l'eau corrumpue. Helas! que doloreux trespas! Quant ces elemens te refusent, Et de toy recevoir s'excusent, Doubtans que de toi n'empirassent! Que feras tu, pueur infecte?

Só resta, portanto, colocar a carniça sob a terra, em uma fossa profunda, coberta por uma grande pedra - “tenebreuse maison”. Sua única companhia são os vermes engendrados pela própria carne putrefata.

Il conviendra que l'en te mecte L'ou l'en met tous ceulx qui trespassent:

En une grande, parfonde fosse, Selon que la charoigne est grosse, Comme se droit venin estoies, L'en t'enfouira dedans la terre, 
Et couvrira d'une grant pierre

Affin que jamais veu ne soyes.

O tres tenebreuse maison!

O charoigne qui n'es mais hon,

Qui te tenra lors compaignie?

Ce qui istra de ta liqueur:

Vers engendrés de la pueur

De tal vil char encharoignie. ${ }^{80}$

É pouco o que se conhece a respeito do poeta; por exemplo, que trabalhou para Jean, o duque de Berry, e sua corte, durante alguns anos, e a data de algumas de suas composições. No entanto, “ce que nous pouvons affirmer, c'est que Leçons de Job ont eu un grand succès, qu'elles correspondaient bien au sentiment de cette époque funèbre. Car nous en connaissons de nombreux manuscrits. " 81 Champion enumera nove desses manuscritos que contêm os Vigiles, de Nesson.

São versos eloquentes da sensibilidade macabra também aqueles atribuídos ao rei René d'Anjou (1409-1480), escritos em um quadro de sua autoria que, até a Revolução Francesa, ficava no convento dos celestinos, em Avignon (e que, depois, desapareceu). A tela, sem data precisa, representava um cadáver feminino em pé, bem penteado, envolto em mortalha, que os vermes atacavam e comiam as entranhas. ${ }^{82} \mathrm{O}$ primeiros versos falam da transformação da bela dama, fresca e tenra, que vestia seda e habitava um palácio em um corpo nu que vai se tornar cinzas dentro de um caixão em uma fossa cheia de aranhas :

Une fois sur toute femme belle Mais par la mort suis devenue telle.

Ma chair estoit très belle, fraische et tendre, Or est-elle toute tournée en cendre.

Mon corps estoit très plaisant et très gent, Je me souloye souvent vestir de soye, Or en droict fault que toute nue je soye. Fourée estois de gris et de menu vair, En grand palais me logeois à mon vueil, Or suis logiée en ce petit cercueil. ma chambre estoit de beaux tapis ornée, Or est d'aragnes ma fosse environée. ${ }^{83}$

\footnotetext{
${ }^{80}$ retirado de CHAMPION, 1923, p. 202-5. Manteve-se a grafia desta fonte.

${ }^{81}$ CHAMPION, 1923. p. 213.

${ }^{82}$ VOVELLE, 1983, p. 109.

${ }^{83}$ Retirado de HUIZINGA, 2010, p. 227.
} 
$\mathrm{O}$ efeito da pintura e das inscrições devia aumentar consideravelmente com a lenda, surgida um pouco depois da confecção da obra, "segundo a qual o próprio artista em carne e osso, amante da vida e da beleza por excelência, teria visto a sua amada no túmulo três dias após ter sido sepultada, e então a pintou. "84

Também o mansucrito original do poema inglês Disputacioun Betwyx the Body and Wormes (ca. 1435-1440) conta com impressionantes ilustrações que complementam o teor macabro do texto. Herdeiro do gênero do Debate entre a alma e o corpo, o Disputacioun traz uma diferença essencial com sua ascendência: "the conversation in this poem occurs not between the body and the soul but between the body and the worms that are eating it as it lies in the grave." 85 O documento, anônimo, está depositado no British Museum (Ms. Add. 37049), em uma coletânea de textos do começo do século $\mathrm{XV}$, recolhidos em um monastério cartuxo do norte da Inglaterra. ${ }^{86}$ Em sua primeira página, uma ilustração em cores do que parece ser um túmulo composto, de dois andares, ou os dois estágios da morte física: no de cima, uma efígie de jacente, uma figura feminina, vestida à moda da época, semblante sereno e mãos postas sobre o peito. No de baixo, seu cadáver retorcido, embrulhado em mortalha, de pele ressequida e caveira aparente, sem cabelos, infestado de vermes, baratas e animais infames de toda sorte (figura 21).

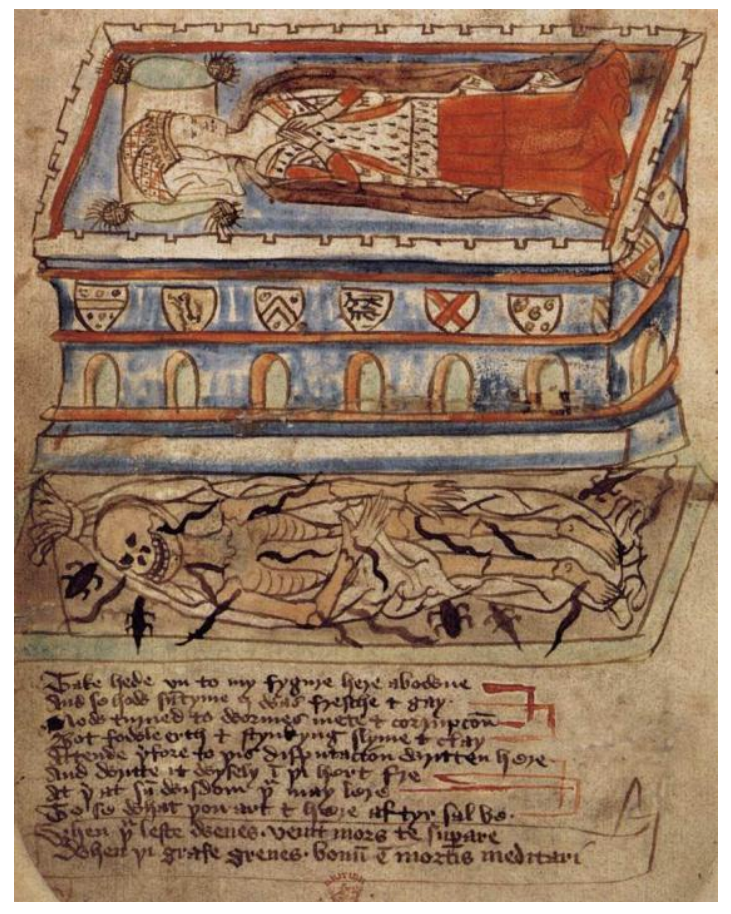

\footnotetext{
${ }^{84}$ HUIZINGA, 2010, p. 228.

${ }^{85}$ RYTTING, 2009, p. 2.

${ }^{86}$ Idem, ibidem.
} 
O narrador do poema, um peregrino não identificado escapando da Peste, pára em uma Igreja que encontra em seu caminho para rezar e é distraído pelo túmulo recémconstruído de uma dama "of true noble birth".. Ao ler seu epitáfio, entra em uma espécie de divagação, um tipo de "sonho acordado", no qual ouve a conversa entre o corpo enterrado e os vermes que o comem ("I heard, strange to say, all manner of jawing / Between this fair corpse and the worms on her gnawing / In the manner of a dialogue it went"). A tônica dos versos é revelar a vanidade das vaidades, ao enfatizar o horror dos processos post-mortem. O corpo, antes uma figura "fresh and sweet", está agora nu, desprotegido, sendo devorado até os ossos sem descanso, pelo apetite insaciável desses parasitas cada vez mais robustos de tanto se fartarem ("Now you've grown fat and ugly and round [...] Leave me alone, out of courtesy, / For I'm almost gone - almost eaten away!')

The Body speaks to the Worms:

"Worms, O worms," this body mourned.

"Why do you thus? What makes you eat?

By you my flesh is foully adorned,

Which once was a figure fresh and sweet, Right amiable, fragrant, and always neat.

Of all creatures I was loved the best,

Called lady and sovereign, I do attest.

Most unnatural neighbors that ever were known!

You have me for lunch and for supper at night,

Now gnawing and eating me right to the bone

With a greedy, insatiable appetite.

There's no rest, for always you suck and bite.

You won't abstain for a single hour

But are always ready to cruelly devour!

Os vermes não deixarão o cadáver até que dele só sobrem os ossos - deixados limpos, polidos, "not a join neglected". Irônicos, relembram à jovem que, no estado em que ela se encontra, apodrecida e fétida, qualquer outra criatura a repudiaria, exceto eles: 
The Worms speak to the Body:

"No, no, we won't depart from you

While one of your bones with another's connected,

Till we have scoured and polished 'em, too,

Made 'em clean as can be, not a joint neglected.

And for our work, there's no pay expected.

For gold, silver, or riches we have no need.

We only ask your flesh on which to feed.

For we have no way of tasting or smelling

Your horrible, rotting, stinking waste.

All creatures find you extremely repelling

Except for us worms; we're already disgraced.

If we, as beasts, could smell or taste,

Do you think that we your corpse would touch?

Nope, we'd surely avoid it, thank you very much!" 87

François Villon (1431- após 1463), com a habilidade que tem um grande poeta, não precisou de mais do que uma estrofe para descrever as perturbações físicas e a agonia do momento final:

La mort le fait fremir, pallir,

Le nez courber, les vaines tendre,

Le col enfler, la chair mollir,

Joinctes et nerfs croistre et estendre. ${ }^{88}$

Suas meditações pungentes sobre a morte, seu assunto preferido, fizeram com que o Grand Testament, de 1461, fosse uma obra muito lida em sua época e nos séculos seguintes. Francês nascido em Paris, cidade na qual eventualmente residia, Villon, como muitos de seus contemporâneos, conhecia e frequentava o cemitério de SaintsInnocents. Lá ficava ainda mais latente sua atração pela morte física, que via exposta sem constrangimento nos ossuários e carneiros, amontoados de despojos ali depositados indistintamente - pobres ou ricos, senhores ou servos. Eles aparecem no texto de seu testamento, em um trecho ao mesmo tempo solene e engraçado, no qual o poeta deixa

\footnotetext{
${ }^{87}$ retirado de RYTTING, 2000. A grafia não é a original, bastante incompreensível, mas, sim, uma tradução feita por J. Rytting.

${ }^{88}$ retirado de CHAMPION, 1923, p. 129.
} 
seus óculos (sem o estojo!) como doação à instituição parisiense de ajuda à cegos, depois hospital, Quinze-Vingt - que, pelo sistema numérico local equivale ao número trezentos (era essa a quantidade de leitos que o prédio comportava):

Item je donne aux Quinze-Vingt

Qu'autant vaudrait nommer Trois-Cents

De Paris, non pas de Provins,

Car à eux je tenu me sens

Ils auront, et je m'y consens,

Sans les étuis, mes grand'lunettes,

Pour mettre à part, aux Innocents,

les gens de bien des déshonnêtes.

$(\ldots)$

Quand je considère ces têtes

Entassés en ces charniers

(...)

Et icelles qui s'inclinaient

Unes contre autres en leurs vies;

Desquelles les unes régnaient

Des autres craintes et servies:

Là les vois toutes assouvies,

Ensemble en un tas pêle-mèle:

Seigneureries leur sont ravies.

Clerc ni maître ne s'y appelle. ${ }^{89}$

Por serem escritos em língua vulgar e não no latim, estima-se que estes textos tiveram a atenção também de um público menos letrado e culto. Seu real alcance, assim como seu verdadeiro lugar na difusão do macabro, é difícil de mensurar. A esse respeito, sabe-se do papel fundamental das ordens mendicantes em popularizar a imaginação macabra. Tanto a iconografia (em especial as gravuras, por sua portabilidade), quanto a literatura, foram instrumentos bastante explorados pelos frades em suas peregrinações. Seus sermões insistiam na pobreza, no arrependimento, na caridade, nas obras, como garantias necessárias de uma boa morte e da salvação da alma. O macabro funcionava como um memento mori expressivo, corroborando esse discurso através do medo da corrupção da carne e do horror post-mortem.

\footnotetext{
${ }^{89}$ VILLON, 1859, p. 227.
} 
Ora, a fascinação com o cadáver, posto a lume nas manifestações visíveis da cultura, se dava em proporção inversa ao seu ocultamento na realidade: " $O$ que a arte macabra mostrava era precisamente o que não se via, o que se passava debaixo da terra, o trabalho escondido da decomposição, e não o resultado de uma observação, mas produto da imaginação. "90 A morte macabra foi uma etapa do reconhecimento do homem em seu próprio corpo e, consequentemente, da construção do indivíduo moderno. Os séculos seguintes assistem a continuação desse processo.

${ }^{90}$ ARIÈS, 1998, p. 147. 


\section{No rastro do macabro medieval}

La première fois que j'ai pris la main à la nature vraie, ce fut à la Morgue.

Jules Janin, L'âne mort, 1829

La création triste, aux entrailles profondes, Porte deux Tout-puissants, le Dieu qui fait les mondes,

Le ver qui les détruit.

Victor Hugo, L'epopée du ver, 1877

Ah! certo eu vi! - um pútrido cadáver, Amarelento, ensanguentado e feio, Pávido erguer-se no sudário envolto.

Gonçalves Dias, Fantasmas, 1846.

O imaginário do cadáver em decomposição se popularizou após a Baixa Idade Média. A tarefa de traçar seus percursos no decorrer dos séculos modernos é difícil: reapropriado por obras de natureza outra, que não tinham por objetivo os ensinamentos cristãos que garantiam uma boa morte e exploravam seu aspecto horrível e repugnante, o macabro medieval se fundia a gêneros literários e iconográficos como o do terror ${ }^{91}$ ou do grotesco, ${ }^{92}$ por exemplo.

\footnotetext{
${ }^{91}$ Conforme definição de Ann Radcliffe, na qual Terror seria o sentimento de antecipação (medo ou ansiedade) diante de uma situação indeterminada, obscura, que pode ou não representar uma ameaça. "The union of grandeur and obscurity (....) expands the soul and awakens the faculties to a high degree of life." (RADCLIFFE, 1826, p. 150)

${ }^{92}$ Conforme definição de Bakhtin: $O$ exagero, o hiperbolismo, a profusão e o excesso são, segundo opinião geral, os sinais característicos mais marcantes do estilo grotesco. (BAKHTIN, 1987) Segundo Georges Minois: "O grotesco surge, em geral, na sequência das agitações políticas e sociais que inverteram a ordem "natural"das coisas e que nos levam a ter um olhar novo sobre o mundo: este se desestrutura, decompõe-se; seus elementos fundem-se uns nos outros, recompõem-se de forma mosntruosa e ridícula. (...) A palavra aparece com a descoberta, pouco antes de 1500, de antigas decorações complexas no subsolo, as "grotas"da Casa Dourada de Nero. Trata-se de uma invenção mediterrânea, que dá lugar, desde o início do século XVI, a um estilo pleno de fantasia, bizarrice, evocando o sonho e, ás vezes, a loucura. A coisa existia antes da palavra, isso é certo; mas no século XVI, ela entra no vocabulário e adquire verdadeira autonomia." (MINOIS, 2003, p. 94 e 301)
} 
Assim, se é possível rastrear as reminiscências do macabro de outrora, elas se manifestam, por um lado, na manutenção do tema das danças macabras, como continuidade (e, às vezes, reinterpretação) das fabulações medievais. Por outro lado, na imagem do defunto putrefato e todas as infâmias que participam do seu repertório (a carniça e a carcaça, os fedores, os miasmas e a sânie, os líquidos viscosos e nojentos, os vermes e os parasitas que nele se alimentam) que reaparecem na sensibilidade romântica a partir da segunda metade dos setecentos. No primeiro caso, o conjunto de obras que receberam o título de "danças macabras", ou que emularam o modelo medieval de alguma maneira, podendo ser assim classificadas, forma um corpo relativamente coeso, que será analisado no próximo capítulo. O segundo caso é preciso investigar com mais cautela. Esvaziado do seu poder pedagógico, o cadáver servirá, nessa literatura, como um potencializador das cenas de horror. ${ }^{93}$

\section{A febre gótica}

O final do século XVIII, “momento em que se assiste ao teatro da crueldade do marquês de Sade, a volta do sentimento dos cemitérios, da nostalgia e do préromantismo", 94 testemunha uma redescoberta dos temas da cultura medieval, tendo por catalisador a já conhecida obsessão dos românticos pelo período: "Le moyen âge est sans doute l'époque historique vers laquelle, en imagination, le romantisme s'est le plus intensément projeté." 95 Essa inclinação é presente mesmo no seu léxico: é bastante conhecida a definição de Mme de Staël, de 1813, segundo a qual "o termo 'romântico' foi introduzido recentemente na Alemanha para designar a poesia que teve origem nas canções dos trovadores, a que nasce da cavalaria e do Cristianismo." " se manteve mesmo nos estudos contemporâneos sobre a escola, como sugere Michel Löwy: “No termo 'romântico' tal como era compreendido nos começos do movimento

\footnotetext{
93 Conforme definição de Radcliffe, na qual Horror é o sentimento de repulsa que se sente logo após a revelação ou a experimentação de algo potencialmente ameaçador. Enquanto o Terror "expands the soul and awakens the faculties to a high degree of life", o Horror, ao contrário, "freezes and nearly annihilates them". (RADCLIFFE, 1826, p. 150)

${ }^{94}$ VOVELLE In: BRAET e VERBEKE, 1996, p. 17.

95 Assim inicia o verbete Moyen Âge do Dictionnaire du Romantisme (VAILLANT, 2011, p. 477).

${ }^{96}$ Mme de STAËL In: GOMES, 1992, p. 87.
} 
que exibia esse nome existe a referência a um passado bem determinado: a Idade Média. Uma das principais origens da palavra é o romance cortês medieval. "97

A voga teria sido estimulada por diversos fatores. $O$ grande interesse historiográfico de uma geração de pesquisadores que trouxe à tona a cultura medieval sem o preconceito iluminista, como John Ruskin, Champollion-Figeac, Hyacinthe Langlois ou Jules Michelet, que resultou em textos impregnados de emoção saudosista. $^{98}$ Também a redescoberta de autores da época, como François Villon, e a republicação de romances de cavalaria ou de peças literárias como as Reliques of Ancient English Poesy, do Bispo Percy, em 1765, que recuperava baladas populares ou, ainda, a invenção dessa mesma literatura (como no caso emblemático dos Cantos de Ossian), foram particularmente importantes a esse processo. O fascínio pelo estilo gótico na arquitetura (cujas catedrais inspiraram Caspar David Friedrich, John Constable e Pérez Villaamil, e eram elogiadas por Goethe ${ }^{99}$ ), e sua retomada no neogótico (do qual as restaurações executadas por Viollet-le-Duc pela França ou mesmo a concretização dos delírios monumentais de Horace Walpole, na Inglaterra, são apenas dois exemplos) são outras facetas da mesma voga.

A Idade Média cumpriria, para esse início de Romantismo, ${ }^{100}$ o papel de mito fundador, uma pré-história da sociedade moderna ${ }^{101}$, em contraposição à Antiguidade,

\footnotetext{
${ }^{97}$ Em Michel Löwy (1995, p. 41). De acordo com o mesmo autor: a utilização dos adjetivos [romântico, romantismo] remonta ao século XVII, sobretudo na Inglaterra e na Alemanha. No início, são utilizados para qualificar tudo o que é considerado como característico dos "romances"- medievais e mais tardios: exaltação dos sentimentos, extravagância, maravilhoso, cavalaria, etc. Os dois pontos de focalização são a emoção e a liberdade de imaginação. Se estas representam valores negativos para o século XVII, tornam-se cada vez mais positivas no decorrer do XVIII (...) (Idem, ibidem, p. 71)

${ }^{98}$ Interessante observação de Eric Hobsbawm a respeito da influência desses autores: Em outra época, um Lamennais ou um Jules Michelet na França, um Carlyle ou um Ruskin na Grã-Bretanha poderiam ter sido poetas ou romancistas com algumas opiniões acerca de assuntos públicos; na sua época foram propagandistas, profetas, filósofos ou historiadores levados por um ímpeto poético. (HOBSBAWM, 2006, p. 373)

99 Em famososo artigo de 1772, “Architecture Allemande" ("Sobre a arquitetura alemã”), sobre a catedral de Strasbourg, na qual diz encontrar a beleza onde o senso comum só vê "violência $e$ imperfeição" (GOETHE, In: LOBO, 1987, p. 23).

${ }^{100}$ Não se trata, aqui, nos limites desse trabalho, de oferecer uma análise exaustiva sobre o Romantismo. Tantos outros autores já o fizeram e com muito mais propriedade. Pelo contrário, nos interessa um entendimento mais abrangente, no sentido de uma sensibilidade romântica, para aquém e para além dos limites cronológicos do movimento que recebeu essa denominação - e lançar luz à sua vertente mais medievalista e a sua parcela literária que fez uso da estética macabra. No entanto, o compromisso acadêmico talvez nos exija essa "declaração de princípios", no que entendemos ser o Romantismo. Para tanto, nos apropriaremos da voz de um eminente historiador, Eric Hobsbawm, que diz: Como um estilo, uma escola, uma época artística, nada é mais difícil de definir ou mesmo de descrever em termos de análise formal. Os próprios românticos pouco nos ajudam, pois, embora suas próprias descrições sobre o que buscavam fossem firmes e decididas, também careciam frequentemente de conteúdo racional. Em um sentido etsrito, o romantismo surgiu como uma tendência militante e consciente das artes, na Grã-
} 
modelo para o Neoclassicismo. A pastoral medievalista via nos tempos de outrora a cura para uma certa melancolia que invadia as mentalidades coletivas no limiar do século XVIII. "Le romantisme", lembra Edgar Morin, "est tout d'abord crise d'inadaptation à l'embourgeoisement." ${ }^{\text {"102 }}$ Idealizado, o período anterior ao surgimento da sociedade industrial e do capitalismo, era valorizado como o da vida em comunidade, de povos primitivos que se relacionavam harmônica e intimamente com a natureza e com a religião. ${ }^{103}$ Construção utópica, que não passava despercebida nem aos críticos da época, que, de acordo com Théophile Gautier, exclamavam: “- Encore du moyen âge, toujours du moyen âge! qui me délivrera du moyen âge, de ce moyen âge qui n'est pas le moyen âge? Moyen âge de carton et de terre cuite qui n'a du moye âge que le nom." 104

"Cette création d'un monde arbitraire, où le moi, heurté par la dure realité, puisse s'épanouir, c'est le mouvement premier de l'âme romantique”, confirma Albert Béguin. ${ }^{105} \mathrm{E}$ a dura realidade da qual buscavam escapar os românticos era a desse tempo regido pela máquina, revelando o temor da mecanização do próprio homem, do qual a história da Olympia de Hoffmann é representativa, e o Frankenstein de Shelley, um sintoma. "A Idade Média é glorificada; épocas pós-medievais são escolhidas só para descrever, com nostalgia, a derrota e o desparecimento de tradições

\footnotetext{
Bretanha, França e Alemanha, por volta de 1800 (no final da década da Revolução Francesa), e em uma área bem mais ampla da Europa e da América do Norte depois da batalha de waterloo. Foi precedido antes da Revolução (principalmente na Alemanha e na França) pelo que tem sido chamado de "préromantismo"de Jean Jacques Rousseau, e a "tempestade e impeto"dos jovens poetas alemães. provavelmente, a era revolucionária de 1830-1848 assistiu a maior voga européia do romantismo.(HOBSBAWM, 2006, p. 357-8). Recorreremos ao mesmo autor ainda outras vezes nesse capítulo.

${ }^{101}$ No Brasil, o Medievalismo seria substituído em grande parte pelo Indianismo, não apenas na valorização do "homem em relação direta com a natureza", e ainda não corrompido pela sociedade, mas porque representava o período anterior à colonização. Também facilitava a transposição dos temas do romantismo europeus para a realidade local, como a natureza exótica e sublime. Dessa vertente, destacam-se os Primeiros Cantos (1846) e Os timbiras (1857), de Gonçalves Dias, A confederação dos Tamoios (1857), de Gonçalves de Magalhães, O guarani(1857) e Iracema (1865), de José de Alencar.

${ }^{102}$ MORIN, 1970, p. 300. Ainda citando Edgar Morin: le romantisme est une réaction anthropologique à la civilisation bourgeoise, capitaliste, urbaine, puis machiniste et industrielle. (Ibidem, p. 186)

${ }^{103}$ A ansiedade que se convertia em obsessão nos românticos era a recuperação da unidade perdida entre o homem e a natureza. O mundo burguês era profunda e deliberadamente anti-social (...) Três fontes abrandaram a sede da perdida harmonia entre o homem e o mundo: a Idade Média, o homem primitivo [ou, o que dá no mesmo, o exotismo e o "povo" (folk)], e a Revolução Francesa. (HOBSBAWM, p. 365).

${ }^{104}$ GAUTIER, Introdução à Mademoiselle de Maupin, 1835.

${ }^{105}$ BÉGUIN, 1986, p. 50.
} 
veneráveis. "106 Portanto, a retomada da cultura medieval explicaria, em parte, o reaparecimento do macabro, embora não tenha sido a única responsável.

A triunfante moral burguesa pós-revolucionária refletia esse estado de inércia amorfa, mais preocupada com o consumo e com sua imagem social do que com os rumos da civilização. O período da consolidação de seu estilo de vida, contemporâneo ao desenvolvimento do Romantismo, na passagem do século XVIII para o XIX, não por acaso recebeu o epíteto de "a gélida era da burguesia" por Eric Hobsbawm.

\begin{abstract}
Um protestantismo beato, rígido, farisaico, sem intelectualismo, obcecado com a moralidade puritana a pornto de tornar a hipocrisia sua companheira automática, dominou essa desolada época.(...) Seus homens personificavam o dinheiro, que provava seu direito de dominar o mundo; suas mulheres, que o dinheiro dos maridos privava até da satisfação de realmente executar o trabalho doméstico, personificavam a virtude da classe: ignorantes, sem instrução, pouco práticas, teoricamente assexuadas, sem patrimônio e protegidas. ${ }^{107}$
\end{abstract}

A despeito desse "protestantismo beato", os tempos eram nitidamente anticlericais, em que cada vez mais se afrouxavam os laços ideológicos que ligavam o homem à religião, em especial nas cidades: "Embora em termos puramente quantitativos e religião continuasse muito forte, ela não era mais dominante mas recessiva.(...) A tendência geral do período desde 1789 até 1848 foi, portanto, de uma enfática secularização." $108 \mathrm{O}$ discurso racionalista impregnava as discussões filosóficas, influenciando também uma minoria de livres-pensadores que buscava se desvencilhar da Igreja. "A crítica da religião empreendida pela filosofia do século XVIII enfraqueceu o cristianismo como fundamento da sociedade", relembra ainda Octavio Paz. ${ }^{109}$

Ainda que a grande maioria da população, em especial as massas camponesas e proletárias, continuasse crente, essa mudança de fundo ocorria de forma tão sutil e gradual que só era possível observá-la nas nuances do comportamento humano e em algumas de suas manifestações visíveis - como na laicização dos testamentos,

\footnotetext{
${ }^{106}$ CARPEAUX, In: GUINSBURG, p. 163.

${ }^{107}$ HOBSBAWM, 2006, p.263-4.

${ }^{108}$ HOBSBAWM, p. 306-9.

${ }^{109}$ PAZ, 1984, p. 75.
} 
documentos até então impregnados de discurso piedoso e que se tornaram meros registros de transferência de patrimônio. ${ }^{110}$ Diante desse dado, seria possível afirmar que, ao mesmo tempo que as religiões continuavam a existir, intimamente os homens pareciam duvidar cada vez mais de seus pressupostos, sendo um deles, a convicção da imortalidade da alma, um dos bastiões da fé cristã. Era "o fim de um monopólio ideológico", diria Vovelle. ${ }^{111} \mathrm{O}$ óbito passava a ser considerado uma ruptura brusca, o desfecho da única realidade da qual se tinha certeza. A Encyclopèdie, de Diderot e D’Alembert, obra emblemática do pensamento racionalista, já considerava que:

\begin{abstract}
la mort uniquement considerée sous le point de vue qui nous concerne, ne doit être regardée que comme une cessation entière des functions vitales (...) La séparation de l'âme d'avec le corps, mystere peut-être plus incompréhensible que son union est un dogme théologique certifíe par la Religion mais nullement conforme aux lumières de la raison, ni appuyé sur aucune observation de Médicine (...) ${ }^{112}$
\end{abstract}

Aos olhos da razão e da ciência, a morte era meramente cessation entière des functions vitales. Mesmo que permanecesse corrente o discurso religioso, às vezes em suas formas mais histéricas, vide a emergência e o fotalecimento das correntes evangélicas em meados do século XIX, era inegável o processo de materialização do óbito. Dessacralizada, tornada um fim absoluto, etapa incontornável da natureza, a morte se secularizava. Assim concebida, a vida se revelava uma existência vazia, que terminava nela mesma. Sem mistérios, sem segredos. A confiança de que, após a morte, se seguiria um renascimento, em outro plano, sob outra forma, espiritual ou seja qual fosse, fora abalada. Condenado a ser um corpo que apodrece, o homem amendrontavase.

O resultado imediato dessa nova percepção foi, segundo Philippe Ariès, a origem do medo da morte que "manifestou-se pela repugnância, primeiro em representar e, depois, em imaginar o morto e seu cadáver. ${ }^{" 113} \mathrm{~A}$ assepsia burguesa não aceitava o contato com a decomposição humana e passava a escondê-la, evitá-la. A

\footnotetext{
${ }^{110}$ É Michel Vovelle quem nos fornece o dado. O historiador fez um longo e aprofundado estudo sobre as transformações dos testamentos, que aparece em Piété baroque et déchristianisation en Provence au XVIIIe siècle. Les attitudes devant la mort d'après les clauses des testaments. Paris: Plon, 1973.

${ }^{111}$ VOVELLE, 1983, p. 532.

112 Encyclopèdie, p. 718.

113 ARIÈS, 2003, p. 158.
} 
morte, como um todo, vai, aos poucos, sendo tratada como um assunto tabu, que não podia ser mencionada e muito menos vista, e os mortos, considerados objeto de horror.

Nada mais provável, portanto, que a imaginação romântica, em sua vertente crítica da pudicícia burguesa, ${ }^{114}$ tomasse para si os temas que agrediam a sensibilidade da época e desafiavam a lógica racionalista. $\mathrm{O}$ redespertar do macabro foi um deles.

Théophile Gautier comentava, em seu prefácio à Mademoiselle de Maupin, a "recente" (o texto é de 1835) epidemia medieval que atacara Paris e os arredores, aparentemente sem grande importância - "certainement plus innocent que les jeux innocents, et qui ne faisait mal à personne." Mas o público "se prit d'un belle passion pour ce pauvre moyen âge" que invadia tudo: "drames, mélodrames, romances, nouvelles, poésies, vaudevilles. ${ }^{, 115}$ E revela um dos gostos mais emblemáticos à cultura do macabro da época:

A côté du roman moyen âge verdissait le roman-charogne, genre de roman très agreable (...) Les feuilletonistes sont bien vite arrivés à l'odeur comme des corbeuax à la curée, et ils ont dépecé du bec de leurs plumes et méchamment mis à mort ce pauvre genre de roman qui ne demandait qu'à prospérer et a se putréfier paisiblement sur les rayons graisseux des cabinets de lecture. Littérature de morgue ou de bagne, cauchemar de bourreau, hallucination de boucher ivre et d'argousin qui a la fièvre chaude! Ils donnaient bénignement à entendre que les auteurs étaient des assassins et des vampires, qu'ils avaient contracté la vicieuse habitude de tuer leur père et leur mère, qu'ils buvaient du sang dans des crânes, qu'ils se servaient de tibias pour fourchette et coupaient leur pain avec une guillotine. Et pourtant ils savaient mieux que personne que les auteurs des ces charmantes tueries étaient de barve fils de famille, très debonnaires et de bonne société (...) Mais, quoi qu'ils dissent ou qu'ils fissent, le siècle était à la charogne, et le charnier lui plaisait mieux que le boudoir $(\ldots)^{116}$

O "romance-carniça", de que fala Gautier, conhecido ainda como "romance gótico" ou "negro", tinha como principais características a ambientação em construções

\footnotetext{
${ }^{114}$ Hobsbawm chama a atenção para a vertente do Romantismo que, ao contrário, glorificava a classe burguesa em seu elemento histórico revolucionário: $O$ romantismo não é, portanto, simplesmente classificável como um movimento antiburguês. De fato, no pré-romantismo das décadas anteriores à Revolução Francesa, muitos de seus slogans característicos tinham sido usados para a glorificação da classe média (...) (2006, p. 359) No entanto, após o momento revolucionário, ficaria mais claro contra quem e o que se manifestar: Entretanto, já que a sociedade burguesa triunfara de fato nas Revoluções Francesa e industrial, o romantismo inquestionavelmente se transformou em seu inimigo instintivo, e pode muito justamente ser considerado como tal. (Idem, p. 360)

${ }^{115}$ GAUTIER, 1876, p. 13.

${ }^{116}$ GAUTIER, 1876, p. 13-15.
} 
medievais e uma narrativa que incluia elementos fantasiosos e mistério, componentes que confrontavam a lógica racionalista. Remeter-se a um passado remoto não gerava apenas o cenário desejado: os prédios góticos foram ressignificados pelo Romantismo. Catedrais, com seus vitrais de reflexos oníricos e altíssimas torres tornavam-se enigmáticas; o castelo-fortaleza protegia e escondia segredos de outras gerações; o monastério, verdadeiro labirinto de quartos e capelas que ocultavam confissões e assassinatos: o terror e o crime encontravam aí seus cenários ideais.

Precursores, autores ingleses como Horace Walpole (The castle of Otranto, de 1765), Ann Radcliffe (The misteries of Udolpho, em 1794 e The Italian, de 1797), Mathew Gregory Lewis (The monk, de 1795), Mary Shelley (Frankestein, 1817) e Charles Maturin (Melmoth, 1820) inauguraram o gênero que desafiava os valores burgueses, e que reverberaria durante todo o século XIX. Mesmo configurando-se como uma tendência prioritariamente inglesa quando do seu surgimento, a crueldade presente nos textos definitivamente aproximava-os da obra de um grande autor francês, o Marquês de Sade, morto em 1814. Este por sua vez, teria aderido à estética noir em pelo menos três de seus livros - apesar das críticas do autor das 120 journées de Sodome aos romances góticos. ${ }^{117}$

As histórias de Sade apresentavam "uma abundância de peripécias delirantes $e$ incompatíveis com o real; o macabro e o terror tornam-se os fins reais da criação romanesca, sem preocupação com a verossimilhança." ${ }^{118}$ Era o crepúsculo das Luzes. Fantasmas, visões do além, supertições e feitiçarias, criaturas quiméricas e sanguinárias: abandonava-se a razão em prol dos monstros que a imaginação engendra, como sugeria a gravura de Goya.

É a febre gótica, comenta Eliane Robert Moraes:

A popularidade do gênero pode ser confirmada não só pelo grande número de publicações originais ou traduções colocados à disposição do leitor, mas também aferido pelas inúmeras reedições dessas obras. "O Castelo de Otranto", do medievalista Horace Walpole, que dá ao roman noir sua certidão de nascimento é um exemplo disso: de sua

\footnotetext{
117 Quem afirma é Eliane Robert Moraes: Sade, gótico? certamente, se tomarmos por exemplo La Marquise de Ganges, uma adesão total à estética do roman noir, sim, se nos remetermos a inúmeras passagens de Aline et Valcour, uma obra destinada ao grande público; ou ainda se nos referirmos às novelas de Les crimes de l'amour cujos títulos e subtítulos indicam a filiação ao gênero (...) (MORAES, 1994, p. 78). Quanto às críticas de Sade aos romances ingleses da época, a autora cita seu texto de abertura a Les crimes de l'amour em que ele diz que os autores do gênero pecam pelo "excesso de fantasia" (ver o capítulo $O$ castelo em MORAES, 1994).

${ }^{118}$ CAMARANI, 2003, p. 39.
} 
publicação original em 1765 até o final do século ele terá sucessivas edições. ${ }^{119}$

\section{O macabro romântico}

Foi nas ruínas artificiais de um passado medieval inventado ${ }^{120}$ que esse romantismo de evasão buscou falar de sua própria época: ficcionalizando as cenas brutais do Terror revolucionário e suas espetaculares execuções públicas, confrontando o leitor com seus medos mais íntimos. A inadequação da sensibilidade romântica ao mundo capitalista, que exaltava a moral, a contenção e a parcimônia, ${ }^{121}$ encontrou abrigo dentro dos prédios-fortaleza, de muralhas altas, cujas paredes grossas escondiam centenários corredores tortuosos e quartos ainda mais isolados. Os castelos que atraíam a imaginação romântica eram também circundados pela natureza mais selvagem que se poderia conceber. As sombras e a penumbra dessas paisagens forneciam a atmosfera de mistério $^{122}$ ideal às narrativas - e isso a despeito dos propósitos originais da arquitetura gótica, que, contrapondo-se ao estilo românico, seu predecessor, oferecia uma maior iluminação interna e espaços abertos, amplos e arejados. ${ }^{123}$

\footnotetext{
${ }^{119}$ MORAES, 1994, p. 74.

${ }^{120}$ MORAES, 1994, p. 74.

${ }^{121}$ Sobre a "moderação burguesa": O puritanismo, a religiosidade católica ou evangélica encorajavam a moderação, a poupança, uma sobriedade espartana e um orgulho moral sem precedentes na GrãBretanha, nos Estados Unidos, na Alemanha e na França; a tradição moral do Iluminismo do século XVIII e da maçonaria fazia o mesmo no setor ais emancipado e anti-religioso. Exceto na busca do lucro e na lógica, a vida da classe média era uma vida de emoção controlada e de perpectivas limitadas deliberadamente. (HOBSBAWM, 2006, p. 375)

122 o "sentimento de mistério" era fundamental para a imaginação romântica segundo Antonio Candido: Enquanto a natureza refinada do Neoclassicismon espelha na sua clara ordenação a própria verdade, acolhendo e abrigando o espírito, para o romântico ela é sobretudo uma fonte de mistério, uma realidade inacessível, contra a qual vem bater inutilmente a limitação do homem. Ele a procura, então, nos aspectos mais desordenados, que, negando a ordem aparente, permitem uma visão profunda.Procura mostrá-la como algo convulso, quer no mundo físico, quer no psíquico: tempestade, furacão, raio, treva, crime, desnaturalidade, desarmonia, contraste. (CANDIDO, 2009, p. 349)

${ }^{123}$ A arquitetura gótica, que surge entre os século XII e XIII, ao contrário da românica dos séculos X a XII, buscava a verticalidade (simbolizando a ascensão aos céus; o prédio se torna uma ponte que leva os homens à Deus) e as paredes vazadas (preenchidas por vitrais coloridos, explorando ao máximo a entrada de luz solar, que representava a luz divina) através do uso de colunas terminadas em arcos ogivais e arcobotantes externos. A revolução do estilo gótico era justamente a criação do edifício religioso amplo, aberto à comunidade, com abundante iluminação. (Ver mais em DUBY, Georges. O tempo das catedrais. A arte e a sociedade. 980-1420. Lisboa: Estampa, 1993.) No Romantismo, a construção gótica sofre uma ressignificação, sendo obscurecida e tornando-se sombria e aterrorizante (cenário ideal para as ficções sobrenaturais), o que condizia com a Idade Média misteriosa e idealizada que os românticos inventaram.
} 
"A emergência do romance gótico está associada a um sentimento que se apodera da Europa na época: o 'mal de vivre","124 (in)disposição do espírito que parece ter acometido toda uma geração na passagem do século XVIII para o XIX e que se expressava no "efeito Werther". Depois da história de amor frustrado do jovem personagem de Goethe, cuja angústia é tão grande que não cabe na vida, o autoaniquilamento parecia ser o desdobramento natural. Sabe-se da suposta onda de suicídios que teria acompanhado o lançamento deste romance seminal, em 1774 - um cronista da época, citado por Michel Vovelle, indica o registro de 239 casos só em Berlim, entre 1781 e 1786 (que, como o historiador francês conclui, "c'est beaucoup!"). ${ }^{125}$ Entre 1776 e 1850, o livro teve pelo menos dez versões para a língua francesa, e, no mínimo, 42 edições, provando ter sido, na França, um verdadeiro sucesso comercial. ${ }^{126}$ No mesmo período, o número de suicídios cresceu notadamente, e

parecem ter subido entre o ano VI e o ano IX e, sob o Império, bateram todos os recordes em 1812. Sob Napoleão, ocorriam quase 150 suicídios por ano em Paris.(...) Não eram vagabundos ou homens sem eira nem beira que decidiam terminar com uma vida infeliz laçando-se ao Sena: eram homens e mulheres abatidos, cuja existência já penosa se tornava a cada dia mais difícil, sem esperanças de melhora. ${ }^{127}$

Nas estatísticas publicadas no Le Constitutionnel, jornal lido pela burguesia parisiense, era possível acompanhar o fluxo anual crescente de suicídios na França:

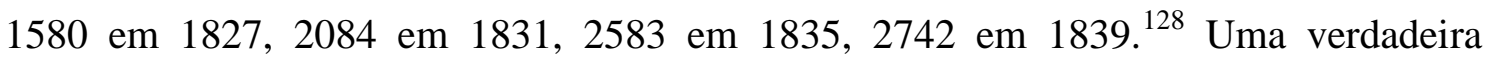
epidemia que, juntamente à tuberculose (o tipo de morte por doença mais próxima ao suicídio, de acordo com as sensibilidades oitocentistas - daí seu nome em francês, “consomption”), substituía as verdadeiras hecatombes demográficas. Dado importante: enquanto o macabro medieval teria sido forjado na ressaca da Peste Negra que assolou a Europa, expondo as entranhas dos cadáveres obscenamente e a qualquer instante, a estética macabra era agora retomada como consequência (e, no limite, como antídoto) do estado generalizado de neurastenia. E isso em uma época em que a ciência aprendia a

\footnotetext{
${ }^{124}$ MORAES, 1989, p. 76.

${ }^{125}$ VOVELLE, 1983, p. 476.

${ }^{126}$ HELMREICH, 1999, p. 179.

${ }^{127}$ HUNT, Lynn In: ARIËS e DUBY, 2006, p. 44.

${ }^{128}$ VOVELLE, 1983, p. 583-4.
} 
lutar de maneira mais eficaz contra as enfermidades, através da medicina ou dos avanços na cultura do cuidado de si (que poderíamos chamar anacronicamente de "higiene"), em que não apenas se morria menos por moléstias tratáveis, como também se vivia mais (a esperança de vida teria aumentando em dez anos durante o século ${ }^{129}$ ). Em suma, o "mal" realmente preocupante era aquele que acometia a alma.

Além do Werther, o público francês descobria naqueles anos a literatura gótica inglesa e rapidamente familiariza-se com os nomes de Horace Walpole, Ann Radcliffe, Matthew Gregory Lewis e Robert Maturin. Traduzidos e avidamente lidos, sem demora, influenciaram uma produção francesa cujo auge foram obras como L'âne mort ou la femme guillotinée (1829), de Jules Janin, e Champavert (de 1833) e Madame Putiphar (de 1839) de Pétrus Borel. Além do "roman-charogne", o Romantismo francês gerou também a chamada "poèsie des cimetières", ${ }^{130}$ da qual poderia se citar, no mínimo, a Comédie de la mort, de Gautier, de 1838, e a Epopée du ver, de Victor Hugo, publicado em 1877, na Légende des siècles.

Esses textos ofereciam ao leitor vitoriano um verdadeiro catálogo macabro. Emblemáticas da vertente "frenética" do romantismo, segundo denominação de Charles Nodier, as narrativas eram recheadas de situações tétricas. Nodier usa o termo em diversas ocasiões para caracterizar essas obras que, filiadas à tradição gótica, exacerbavam na violência e no horror. $\mathrm{Na}$ "Advertência" à sua tradução francesa da peça Bertram, or the Castle of St. Aldobrand, de Maturin, em 1821, por exemplo, ele assume que tal literatura se configurava como o passatempo desejado por um povo acostumado aos terrores e à resignação da vida real:

A une époque où nous avons été tourmentés par le spetacle de tant de douleurs, et frappés de la gloire de tant de dévouemens, il est

\footnotetext{
${ }^{129}$ Au début du siècle, en France, l'espérance de vie à la naissance était un peu inférieure à trente-spet ans - autour de trente-cinq pour les hommes, et de trente-huit pour les femmes; elles est en 1900 de quarante-sept ans (respectivement quarante-cinq et quarante-huit), elle sera de cinquante en 1914. Les Français ont gagné diz ans d'espérance de vie en un siècle, à un rythme, notons-le, inégal.(VOVELLE, 1983, p. 510)

${ }^{130}$ LARMAND, 1910, p. VIII. A poésie des cimetières, por sua vez, além da influência gótica, teria parentesco com os Graveyard Poets ingleses, cujos principais representantes seriam Edward Young (The Complaint, or Night Thoughts on Life, Death and Immortality, de 1742) e Thomas Gray com sua Elegy written in a country churchyard, de 1751 . Entre 1761 e 1830, o poema de Gray teve nada menos que 90 traduções para o francês. Na Alemanha, eles inspirariam o surgimento dos "poetas da noite", os Nachtgedankenmächer. (VOVELLE, 1983, p. 472 e 477). Todos produziam, em geral, reflexões sobre a morte. Nos interessa, contudo, enfatizar, nesse estudos, as produções posteriores a eles, que fizeram uso do elemento macabro mais explicitamente.
} 
d'ailleurs très-comun d'attacher plus de prix à l'éclat d'une entreprise énergique et d'une mort vigoureuse, qu'aux simples et touchantes résignations de la vertu. (...) l'état de notre societé fait très-bien comprendre l'accueil que'elle accorde aux folies sentimentales et aux exagérations passionnées. Les peuples vieillis ont besoin d'être stimulés par des nouveautés violentes. Il faut des commotions électriques à la paralysie, des horreurs poétiques à la sensibilité, et des exécutions à la populace. ${ }^{131}$

O "frenético" encontrou no próprio Nodier seu propagador, seja em Smarra ou les démons de la nuit, de 1821, ou na coletânea de contos Infernalia, de 1822. O cadáver - ou, ainda, os cadáveres: na economia do roman charogne, quanto mais, melhor - se tornava elemento essencial para acentuar o caráter aterrorizante de dado acontecimento, e o romantismo frenético não via limites para a exposição dos corpos decompostos. Sem receio da repetição de certos temas, essa literatura recompensava um público ávido em sentir as delícias da violência e da morte fictícia.

Prazeres que se encontravam em The monk, cujo enredo vale a pena resumir. Estupro, incesto, assassinato, bruxaria e tortura: são esses alguns dos ingredientes da trama de 1796. Nenhum personagem foi salvo dos infortúnios criados pelo autor Charles Lewis, especialmente a pobre Agnes. Prometida à reclusão desde seu nascimento (sua mãe, doente durante a gravidez, jura fazer da filha freira, caso tivesse um parto bem sucedido), ela entra para o convento de Santa Clara, conhecido por sua rigidez e pela severa Abadesa que o dirige. No entanto, Agnes se apaixona por Raymond, com quem pretende fugir. Um mal entendido separa o casal mas, a essa altura, a jovem já esperava um bebê. Ela confessa seu pecado ao celebrado e temido monge Ambrosio, que a entrega à Abadesa.

Temendo pela vida de Agnes, seu irmão Lorenzo se une a Raymond e solicitam ao papa a bula que a libertaria de seus votos. Tendo conseguido o documento, recebem a notícia de que Agnes adoeceu e morreu em seguida. Após um funeral de mentira, Agnes, viva, foi encerrada em um minúsculo calabouço úmido e escuro, escondido sob uma estátua de Santa Clara, nas catacumbas do claustro: "In this dreadful abode she was to lead a perpeteual solitude, deprived of all society, and believed to be dead (...) Thus was she to languish out the remainder of her days, with no other food than bread and water, and no other confort than the free indulgence of her tears." Encontrada ali

\footnotetext{
${ }^{131}$ Nodier in MATURIN, 1821, p. vij (Avertissement).
} 
pelo próprio irmão cerca de um ano depois, irreconhecível pela magreza e pela extenuação, presa por uma corrente instalada na parede de sua funesta cela, Agnes relata os horrores que viveu.

Primeiro, se viu rodeada de freiras mortas, que jaziam ao seu redor nas catacumbas, ("[...] surrounded by the loathsome and mouldering bodies of my companions"), e exalavam odores fétidos ("I was opprest by a noisome suffocating smell [...]”), algumas recém deixadas nas tumbas ("What was my disgust, my consternation! In spite of its putridity, and the worms wich preyed upon it, I perceived a corrupted human head, and recognised the features of a Nun who died some months before!"), além de "skulls, shoulder-blades, thigh-bones and other leavings of mortality were scattered upon the dewy ground." De noite, deitada em seu mísero leito de palha, sentia toda sorte de répteis infames e sapos caminharem sobre seu corpo - como que adiantando as sensações de seu cadáver sendo devorado, o que a apavorava ainda mais.

Os dias passavam e, com o sofrimento e a fome aguda que sentia, seu corpo adiantou o trabalho de parto, que ela teve que realizar sozinha. Sem condições de alimentar ou limpar seu bebê e com o ar gelado e infecto de sua masmorra, o pequeno morre em seus braços, apenas algumas horas depois de ter vindo ao mundo.

I rent my winding-sheet, and wrapped in it my lovely child. I placed it on my bosom, its soft arm folded round my neck, and its pale cold cheek resting upon mine. Thus did its lifeless limbs repose, while I covered it with kisses, talked to it, wept, and moaned over it without remission, day or night. (...) in truth I was not always in my proper senses.

A freira que lhe trazia comida se compadece da situação e se oferece para levar o pequeno cadáver para fora e enterrá-lo. Mas Agnes não concebe se separar do corpo, sua única companhia e conforto. Em pouco tempo, ele começa a apodrecer: "It soon became a mass of putridity, and to every eye was a loathsome and disgusting object." Seus olhos de mãe não permitiam vê-lo com aversão: "In vain did human feelings bid me recoil from this emblem of mortality with repugnance: I withstood, and vanquished that repugnance." Agnes seguia amando e acarinhando o diminuto e asqueroso despojo, procurando ignorar sua aparência e tentando imaginar sua graciosa fisionomia de bebê saudável - sua única ocupação durante o tempo em que ficou encarcerada: 
I persisted in holding my infant to my bosom, in lamenting it, loving it, adoring it! Hour after hour have I passed upon my sorry couch, contemplating what had once been my child: I endeavoured to retrace its features through the livid corruption, with which they were overspread. During my confinement this sad occupation was my only delight.

No momento de seu resgate, Agnes foi encontrada assim, conversando com o mortinho, embalando-o em seu colo e beijando o pacotinho frio de seu corpo.

O encadeamento de horrores se repete em outra obra emblemática do frenético, L'âne mort (1829), que também merece menção. Jules Janin, no prefácio, a chama de seu "castelo gótico" "132, prenunciando a letra noir da narrativa. Apesar do começo idílico, assim que o narrador chega em Paris, a história descamba para uma mordaz crítica social, em uma série de acontecimentos que denunciam o paradoxo moral que permeia todo ato de sociabilidade urbana, que incentiva e ao mesmo tempo pune os vícios - como no caso da prostituta Henriette, que é condenada à morte na guilhotina por assassinar o homem que a corrompeu pela primeira vez. O tom macabro se dá nos encontros do narrador com outros condenados (que já estava mortos...) que relatam suas execuções em detalhes - delitos cometidos, circunstâncias e sensações na hora fatal (o testemunho do enforcado é particularmente angustiante).

Convencido de que as motivações do crime Henriette livrariam do Inferno, o narrador paga ao carrasco para que lhe conceda o corpo após o suplício, decidido a darlhe uma sepultura decente. Às pressas, arranja um precioso lençol para usar de mortalha, e uma fronha com a qual embrulharia a cabeça. Consegue uma cova em um cemitério de segunda categoria, que aceitava enterrar uma criminosa.

A cena merece atenção. Após orientar o coveiro (um tipo um tanto inescrupuloso) a aprofundar a fossa (que desconfiou que estivesse muito rasa), o narrador vê chegarem os guardas que conduziam uma pesada charrete. Estes entregamlhe a conta da execução e o cesto com o cadáver. Um dos guardas abre o embrulho; dele sai uma cabeça coberta de sangue; os belos cabelos de Henriette arrancados pelo fio da lâmina, seus olhos apagados ainda abertos, a boca horrivelmente contraída, fechada de um lado e totalmente aberta do outro; o maxilar assim endurecido, crispado, impressiona o narrador, que exclama: "Malheureuse! elle a dî bien souffrir!" Ainda

${ }^{132}$ JANIN, 1861, p. 11. 
mais abalado ele fica ao ver que o corpo dentro do cesto ensanguentado estava inteiramente nu.

O coveiro pede licença para beber com os guardas no casebre que the serve de escritório enquanto o narrador se recompõe e se despede da pobre decapitada. Com a ajuda de seu amigo Sylvio, arrumam-na no caixão delicadamente, cobrindo-a com o fino sudário arranjado. Nesse processo, são observados por mulheres do povo, que riem e invejam o tecido nobre que cobre a defunta, enquanto elas mesmas se vestem de trapos. O narrador está inconsolável pelo fim dramático da história de sua amada, "cette histoire moitié vice et moitié vertu”, e se derrama em lamentos.

Cai a noite e o funcionário finalmente ressurge, embriagado e entoando "une chanson bachique”. Ele se mostra surpreso de ainda encontrar os dois ali, velando a morta. Não podendo adiar mais sua obrigação, ele deposita o ataúde no fundo da fossa, desajeitadamente. "Courage!" - lhe diz o narrador - "il nous faut dans ce trou beaucoup de terre." O coveiro, então, para dar continuidade aos trabalhos com mais ânimo, se põe a dançar sobre a fossa, cantarolando "J'aime mieux boire!" O narrador se prostra de joelho e começa a rezar, e o coveiro continua saltitando alegremente: "J'aime mieux boire!"

A escatológica sequência não seria a derradeira. Na manhã seguinte, o narrador volta ao cemitério levando flores, a mente "pleine de prières", o coração "plein de pitié" e o olhos "pleins de larmes" para homenagear Henriette. No local, porém, nada encontra além de um buraco vazio no chão. Estudantes de medicina roubaram o cadáver, o coveiro vendeu o caixão à família de outro condenado, as mulheres que ontem assistiam ao fúnebre espetáculo, levaram o lençol e a fronha: “Rien n'était plus."

A escabrosa história de injustiças de Jules Janin obteve grande sucesso, sendo reeditada 17 vezes no decorrer do século. Seguiu seu exemplo a coletânea Champavert, contes imoreaux, de Petrus Borel, de 1833, um desses livros que reverberaram na sensibilidade romântica com suas incontáveis atrocidades. É chamado de "barracão de horrores" e "museu de horror" por Mario Praz. ${ }^{133}$ As atrocidades macabras se repetem por todas as novelas compiladas, chegando a excessos refinados, como no último conto, em que o autor elabora a morte de seu pseudônimo. Personagem atormentado pelo passado e por dúvidas existenciais, Champavert fez um pacto com sua amada, no qual,

\footnotetext{
${ }^{133}$ PRAZ, '996, p. 131-133.
} 
quando um dos dois decidisse tirar a própria vida, o outro faria o mesmo e eles morreriam juntos. Finalmente, ele procura por sua Flava: é chegada a hora. Mas Champavert, antes do ato fatal, tem um último pedido a fazer: ver o cadáver de seu bebê, que a jovem abortou tempos atrás e que ambos enterraram em um jardim.

No meio da noite, debaixo de uma tempestade, os dois chegam ao local. Já bastante transtornado, o poeta cava com as mãos o local da sepultura, e encontra o esqueletozinho ainda coberto de carnes: “- Flava! Flava! Criait-il, tiens, tiens, regarde donc ton fils; tiens, voilà ce qu'est l'éternité! ... Regarde!" Ele joga o pequeno corpo na estrada e, atendendo aos pedidos de uma desesperada Flava, enfia um punhal em seu peito, e depois se mata. O poeta não acredita em Deus ou no Além, acredita no Nada, na vida que termina na morte - e o cadáver decomposto de seu filho é, para ele, a prova derradeira de suas convicções.

Em outro conto, Borel ficionaliza a história do respeitado anatomista do século XVI, Andreas Vesalius, descrito como um sujeito muito magro, alto e calvo, sempre trajando gibão com culotes, o traje todo em preto. Era uma figura digna de reparo. Os convidados à festa de seu casamento, ao verem-no dançando com a rechonchuda Amalia, "rondelette, fraîche et rose, fazem troça: é a imagem da "mort qui fait danser la vie." Ou mais especificamente, uma cena tirada da dança macabra de Hans Holbein ("La danse d'Holbein”)! ${ }^{134}$

A historieta sugeria que, para além de suas polêmicas atividades oficiais, o médico praticasse seu métier de maneira escusa. Os boatos sobre ele espalhavam-se pelo povo, que o considerava um "hérétique", um "nécroman", "sorcier". Ainda no início da narrativa, duas senhoras de ares alcoviteiros comentam, ao passar diante de sua residência na capital espanhola que "si tous ses cliens défunts s'y rendaient, la ronde ferrait le tour de Madrid" - e a tópica das danças dos mortos se faz presente. Um homem que ouve a conversa lhes responde, com graciosa ironia macabra: “-On m'a assuré qu'il déjeûne souvent avec des côtelettes de chair qui ne vient pas de la boucherie." A opinião pública o acusava do desaparecimento de algumas pessoas e exigia punição.

E Vesalius era, de fato, um criminoso que não deixava rastros. No leito de morte, a esposa Maria confessa tê-lo traído três vezes, com três homens diferentes, os

\footnotetext{
${ }^{134}$ Ver capítulo 3.
} 
quais, após passarem a noite juntos, nunca mais viu - ela sempre acordava sozinha e não tinha mais notícias deles. Apesar de mal se manter de pé, o anatomista a conduz, então, ao seu laboratório, pequena sala com paredes de pedra e colunas em ogiva, com mesas ao centro, estantes e armários. "Les établis étaient chargés de cadavres entamés, on foulait aux pieds des lambeaux de chairs, des membres amputés et sous les sandales du professeur se broyaient des muscles et des cartilages." Um esqueleto convenientemente preso atrás da porta chacoalha todo quando essa se fecha, fazendo Maria estremecer. "La voûte et les parois étaient couvertes d'ossements, de râbles, de squelettes, de carcasses, quelqu'uns humain, mais le plus grand nombre de singes et de porcs", animais usados nos estudos de Vesalius. O ambiente de pesquisa, supostamente racional e científico, aqui é sanguinário e repulsivo, causando sentimento oposto; a jovem esposa, assustada e enojada, pede para voltar ao leito ("l'odeur putride de ces corps me suffoque, ouvrez que je sorte, je souffre horriblement!").

É no meio das vísceras e das carcaças que o médico conta a ela o que fez de seus amantes: envenenanava o vinho que Maria bebia com eles, sedando-os. Desmaiados, eram levados ao laboratório. Ainda vivos, mas sem poderem reagir, eram abertos para autópsia. Unindo seus dois interesses, a vingança e os estudos, o anatomista empreendia assim, uma análise cada vez mais minuciosa do corpo humano. Mostrando os cadáveres ocos à esposa, diz: “- Jusqu'ici, n'ayant point encore disséqué de corps vivans, on n'avait eu que de vagues et imparfaites notions sur la circulations du sang, sur la locomotion; mais grâce à vous, señora! Vésalius a levé bien des voiles, et s'est acquis une gloire éternelle." Com o choque da revelação, Maria cai morta - tornando-se, ela também, outra cobaia.

No romance Madame Putiphar, de 1839, a crítica social iniciada por Jules Janin perdura, porém em tom mais sóbrio e trágico (apesar do fabuloso humor negro na cartaresposta de Mme ao pedido de clemência de Fitz-Harris). A história, que se passa entre as décadas de 1760 e 1780, não poupa nenhuma instituição, já que os alvos, aqui, são tanto o Antigo Regime, nas figuras de Luís XV e Mme de Pompadour, quanto o Iluminismo, denunciado pelas inúmeras humilhações, torturas e privações pelas quais passa o inocente Patrick nas prisões laicas para onde é mandado. Sua noiva, Déborah, acaba vítima da depravação da corte, escolhida para ser mais uma das jovens do harém real e iniciada na prostituição pela sáfica Madame du Hausset. 
Dez anos preso: é nessa situação que encontramos Patrick em 1773. O companheiro de cela era o seu amigo Fitz-Harris, dado a rompantes de revolta diante do novo diretor do presídio, um sujeito sem ética nem paciência. Os dois sofrem constantes represálias, obrigados a passar fome e frio em uma cela escura, sem direito a banhos de sol ou passeios. Um dia, Fitz-Harris, no limite com essa situação, explode. Após luta com os guardas, na qual ambos saem feridos, são mandados, como castigo, a uma minúscula masmorra, um poço úmido, sem aberturas e repleta de ratos. Condenados a um regime impiedoso de longos jejuns forçados (interrompidos por porções escassas de pão mofado), trancafiados sem saberem quantos dias se passavam, com seus ferimentos abertos e infeccionados, aos poucos os dois jovens começam a clamar pela morte. A privação extrema desencadeia a insanidade e logo, são acometidos de visões causadas pela penúria. Os corpos fracos, macilentos, trajando apenas farrapos eram alvos constantes das mordidas dos roedores. O pequeno espaço compromete os movimentos dos membros e Fitz-Harris passa a não sentir mais as pernas.

Um dia, após dois anos nessa situação, o amigo de Patrick sofre sérias crises alucinatórias. Em um último esforço de vida (algo que Charles Maturin chamaria de"that ominous energy that annouces its effort to be the last - that bright flash of parting life that precedes its total extinction"135), levanta-se, apesar das chagas espalhadas por toda a pele, e discursa longamente, como num transe. E cai, morto. Patrick se vê só e encerrado com o cadáver do amigo. Por uma semana.

La nature a des lois de destruction et de décomposition inexorables pour le plus bel être comme pour l'objet le plus aimé; et Fitz-Harris étoit mort dans um si mauvais état, et ce puits étoit si malsain, que Patrick n'osoit plus, disons plus juste, ne pouvoit déjà plus l'embrasser, ne pouvoit déjà plus poser ses lèvres sur son front. ${ }^{136}$

Extenuado, desesperado, o pobre homem já não sabe mais o que fazer: a morte não lhe chega por mais que implorasse e o cadáver de seu companheiro se desmanchava ao seu lado. Finalmente, um dos guardas ouve seus gritos mas não se comove, e ele mesmo teria que remover o cadáver. Com o pouco de energia que possui, coloca o resto

\footnotetext{
${ }^{135} \mathrm{O}$ trecho citado está em Melmoth e refere-se a uma personagem que passa pelo mesmo lampejo repentino de ação de Fritz-Harris. (MATURIN, 2012.)

${ }^{136}$ BOREL, 1878, p. 190.
} 
hediondo e imundo do amigo nas costas e, a custo, sobe com ele os degraus da escada. Chegando à superfície, encontra os guardas e o diretor, que imediatamente se afastam por causa do fedor que exalavam. Patrick atravessa o prédio com a massa podre nas costas, levando-o até o jardim, para ser enterrado. Sua aparência, quase tão obscena quanto a do morto, faz a cena ficar ainda mais tétrica: "Un cadavre immobile porté par um cadavre mobile couvert de cheveux et de haillons.(...) L'imagination pourroit-elle concevoir um spetacle plus lugubre, une scène plus propre à glacer d'effroi? ",137

No caso da "poèsie des cimetières" de Théophile Gautier, é possível identificar a premissa do macabro medieval, de revelar o que acontece por baixo da terra, desde $L a$ comedie de la Mort, de 1838. No poema La mort, recupera-se o tema do "Debate entre a alma e o corpo", mas, assim como no antigo poema inglês Disputation Between the Body and Worms, o diálogo se dá entre a jovem recém-enterrada e o verme que a viola. O narrador ouve a conversa ao se aproximar de um túmulo e, num susto que lhe faz ceder os joelhos, entende que o verme "consommait son hymen". A defunta desvirginada reage imediatamente ("La nuit du mariage elle est donc arrivée?"), ao que o verme indecoroso responde:

Cette nuit sera longue, ô blanche trépassée, Avec moi, pour toujours, la mort t'a finacée; Ton lit c'est le tombeau.

Na Epopée du ver, de Victor Hugo, o verme é a morte - não mais entidade abstrata (ou personalização dela), mas a morte no que ela tem de mais material: a destruição do corpo. O parasita que come e aniquila o ser representa esse óbito dessacralizado, no qual o fim último é o do despojo e não o da alma ("Fétide, abject, je rends les majestés pensives. / Je mords la bouche, et quand j'ai rongé les gencives, / Je dévore les dents"). Tanto que "o poeta e o profeta", quando tristes e "pensando na vida feita de desaparecimento", é com ele, o verme, que sonham: "Sage ici-bas celui qui pense à moi sans cesse!"”

E ele segue, rastejando imperceptível entre os homens, nos momentos em que eles se divertem, desprevenidos ('Lorsqu'entendant chanter les hommes, je me glisse, I

\footnotetext{
${ }^{137}$ BOREL, 1878, p. 192.
} 
Invisible, caché, muet, dans leur délice, / Leur triomphe et leur bruit”). Quando se dão conta, "Le ver de terre est là!"

Este verme, que é "a" morte, já está dentro de cada um: "Je suis dans l'enfant mort, dans l'amante quittée, "Dans l'athée" Sua ameaça é intrínseca à existência: "J'habite le décombre", é inevitável, ("On m'extermine en vain, je renais sous ma voûte; / Le pied qui m'écrasa peut poursuivre sa route, / Je le dévorerai"), frequentemente renovada (“Je regarde le fils naître, et j'attends le père / En dévorant l'aïeul."). A humanidade lhe é servida como um banquete: "Le monde est un festin. Je mange les convives."

Je prends l'homme, ébauche humble et tremblante qui pleure,

Le nerf qui souffre, l'œil qu'en vain le jour effleure,

Le crâne où dort l'esprit,

Le cœur d'où sort le sang ainsi qu'une couleuvre,

La chair, l'amour, la vie, et j'en fais un chef-d'œuvre,

Le squelette qui rit.

Ao lado dessas imagens do macabro asqueroso, a sensibilidade romântica forjou o que parece ser seu extremo oposto. Do Melmoth, the wanderer (1820), de Charles Maturin, por exemplo, provém a idéia de uma "beleza cadavérica", essencial para uma certa fruição do cadáver, aquela que, mais do que explorar seu aspecto terrorífico, celebra sua dimensão sublime.

O livro todo é um compêndio de improbidades difíceis de contabilizar. Melmoth aparece nos momentos de extrema dificuldade nas vidas de uma série de personagens, na tentativa de partilhar com eles o pacto que fez com Satanás, de viver mais 150 anos em troca de sua alma. Interessa aqui, particularmente, um trecho no capítulo 28 , no qual a família de Guzman, após sua morte, padece da mais terrível penúria. Desesperados pela fome, cada um tenta, à sua maneira, ajudar: os mais velhos, junto do caçula Maurice, recorrem à mendicância, a bela Julia se prostitui, o varão Everhard vende seu próprio sangue.

Uma noite, Ines, a mãe, ouve gemidos que vêm do quarto dos filhos. Já não se assusta mais, acostumou-se, pesarosa, com os lamentos surdos dos jovens que dormem famintos. Ao seu lado, o marido Walberg dormia pesado, "sunk into that profound sleep wich is often the refuge of intolerable misery." As lamúrias cessam mas, em seguida, 
Maurice aparece ofegante diante de sua cama, completamente lavado em sangue, chorando: “- It's Everhard's blood - he is bleeding to death, - I am covered with his blood! - Mother - mother - rise and save Everhard's life!"

Absorta por alguns instantes pela visão do caçula ensanguentado, Ines parece entrar em uma espécie de pesadelo, a ponto de sequer ouvir os gritos do filho, sensação intensificada pela fraqueza da desnutrição. A voz de Maurice a traz de volta à realidade e eles correm em direção ao quarto. Ao entrar, a mãe se depara com o mais velho estendido na cama encharcada pelo líquido vermelho, que lhe escorria por todo o corpo, pois os braços, de cujas veias jorrava o fluido, estavam jogados sobre a cabeça: "His arms were tossed above his head, and the blood was trickling fast from the opened veins of both, - his bright and curled hair was clotted with the red stream that flowed from his arms, - his lips were blue, and a faint and fainter moan issued from them as his mother hung over him." A luz da lua, que entrava abundante pelas janelas abertas do quarto quase sem mobília, refletida no corpo pálido e agonizante, compunha uma imagem "worthy the pencil of a Murillo, a Rosa, or any of those painters, who, inspired by the genius of suffering, delight in representing the most exquisite of humens forms in the extremity of human agony." O jovem era, nesse momento, a representação de "a kind of corpse-like beauty", um tipo de "beleza cadavérica", que os mortos, imóveis e lívidos, possuem, comparável à das estátuas de mármore: “The snow-white limbs of Everhard were extended as if for the inspection of a sculptor, and moveless, as if they were indeed what they resembled, in hue and simmetry, those of a marble statue."

É essa noção que apareceria, décadas depois, em Une charogne, de Baudelaire, poema de nota acentuadamente macabra, no qual o objeto admirado é um horrível cadáver putrefato, uma "carniça infame": "Rappelez-vous l'objet que nous vîmes, mon âme, / Ce beau matin d'été si doux: / Au détour d'un sentier une charogne infâme (...)". De pernas abertas ao ar, como "une femme lubrique”, a carniça exala miasmas de seu ventre pleno de gases ("Son ventre plein d'exhalaisons"). O sol cozinha suas carnes, brilha sobre sua podredume, atiçando seus líquidos infames e mau cheiro: "La puanteur était si forte que sur l'herbe / Vous crûtes vous évanouir". Essa carcassa "superbe" é comparada a uma flor que se abre, servindo de morada e alimento às moscas, larvas e vermes que nela se multiplicam:

Les mouches bourdonnaient sur ce ventre putride, 
D'où sortaient de noirs bataillons

De larves qui coulaient comme un épais liquide

Le long de ces vivants haillons. ${ }^{138}$

O espetáculo abjeto, envolvente como "une étrange musique", é observado pelo narrador e sua companheira - e por um cão que, ao longe, aguarda o momento de roubar um pedaço do morto. À amada, o narrador declara: seu destino é o mesmo da vil carniça - "vous serez semblable à cette ordure / A cette horrible infection". 139

Publicado na primeira edição de Fleurs du mal, Une charogne provavelmente representa o "clarão macabro" da arte de Baudelaire, aquele nouveau frisson que o poeta teria atribuído à literatura de seu tempo. ${ }^{140} \mathrm{O}$ tratamento dado ao corpo em decomposição choca na medida em que o exalta, o promove a objeto de fruição - mas não era uma total novidade.

\section{O sublime e o cadáver}

Na Poética, Aristóteles discorre sobre o prazer que o ser humano sente pela imitação de objetos reais (na arte em geral, mas para o filósofo, principalmente nas obras que evocam o olhar, como a pintura ou a escultura) - quanto melhor realizada, maior o gozo. "A prova é-nos visivelmente fornecida pelos fatos: objetos reais que não conseguimos olhar sem custo, contemplamo-los com satisfação em suas representações mais exatas. Tal é, por exemplo, o caso dos mais repugnantes animais e dos cadáveres." 141 Sete séculos mais tarde, Santo Agostinho, nas Confissões, condena a prática, declarando que tais imagens serviriam apenas para satisfazer uma curiosidade perversa, negativa, que o autor chama de mera "concupiscência dos olhos", dando o tom tabuístico das representações do cadáver na Alta Idade Média. "Que prazer pode ter na visão de um cadáver dilacerado que causa horror?" - ele pergunta - "E, todavia,

\footnotetext{
${ }^{138}$ BAUDELAIRE, 1857, p. 67.

${ }^{139}$ BAUDELAIRE, 1857, p. 68.

${ }^{140}$ Ambas expressões em destaque são de Victor-Hugo, em carta que este enviou a Baudelaire em 6 de outubro de 1859, após a leitura de Fleurs du mal: "Você dotou o céu da arte de um certo clarão macabro. Você criou um novo frisson. ”(Citado em PRAZ, 1999, p. 140).

${ }^{141}$ ARISTÓTELES, Capítulo IV, item 3. Disponível em http://www.dominiopublico.gov.br
} 
onde há um cadáver, para lá corre toda a gente para se entristecer e empalidecer. É esse quê de mórbido de curiosidade que faz com que se exibam monstruosidades nos espetáculos. " ${ }^{142}$ Nos últimos séculos medievais, como já visto, as imagens dos mortos em decomposição foram abundantes, e foi essa produção que gerou o conceito de macabro.

E se o macabro romântico foi devedor, em certo sentido, do macabro medieval, é certo que ele desenvolveu-se também a partir de princípios próprios. Mais do que enfatizar a passagem do tempo e a vanidade do mundo material, ele propunha o louvor de coisas desprezíveis e repugnantes como a putrescência. Tal premissa estética, a sensibilidade romântica herdara de um paradigma que desde o século anterior invadia os debates sobre a filosofia da arte e as teorias de recepção: o conceito de sublime.

$\mathrm{Na}$ tradição filosófica, um dos primeiros tratados a definirem e analisarem o sublime foi o manuscrito Peri Hypsous, do século I, de autoria atribuída ao retórico romano Cássio Longino, um texto aparentemente ignorado ou raramente lido ${ }^{143}$ até sua tradução para o francês, por Nicolas Boileau, em 1674. Essa versão, batizada Tratado do sublime ou do maravilhoso no discurso, ou apenas Do sublime, teria iniciado o debate moderno sobre o termo, e repercutido especialmente durante o século XVIII. Se em Longino, o sublime limita-se a caracterizar certas passagens poéticas a partir de seu estilo e conteúdo, assim como o efeito que elas causam no leitor (relacionando-se, portanto, apenas a obras artísticas, seja em sua produção como em sua recepção), os teóricos dos oitocentos transferem a categoria do sublime para a Natureza. ${ }^{144}$

Os primeiros representantes da linhagem teriam sido os ingleses John Dennis, em 1701, Joseph Addison, em 1712 e, especialmente, Edmund Burke, em 1757. Uma investigação filosófica sobre a origem de nossas idéias do sublime e do belo busca caracterizar os tipos de objetos sublimes e investigar as relações entre eles e o gosto, e suas diferenças com a experiência do belo. O texto de Burke repercute amplamente e atinge pensadores do quilate de Immanuel Kant. O filósofo alemão dilapida o conceito

\footnotetext{
${ }^{142}$ SANTO AGOSTINHO, Capítulo XXXV. Dispnível em http://www.dominiopublico.gov.br

${ }^{143}$ De acordo com WEISKEL, 1994, p. 29.

${ }^{144}$ De acordo com Longino, o sublime seria "o ponto mais alto e a excelência do discurso", produzido pelo próprio homem e tendo por objetivo elevar a natureza humana (LONGINO, p. 71). Sendo assim, a passagem do sublime retórico para o sublime natural do século XVIII não seria, em absoluto, forçada, uma vez que em Longino, o sublime também teria a natureza como ponto de partida e de chegada. Segundo Weiskel, a voga do sublime nos oitocentos, baseada na leitura do texto romano, veio de encontro com o desejo da época de elevar a Natureza acima de qualquer teologia, promovendo uma transcendência humana sem o suporte da religião (WEISKEL, 1994, p. 29).
} 
na Crítica da Faculdade de Juízo, de 1790; nele, a sublimidade se torna subjetiva, resultante de um juízo estético, e não mais objetiva, como em seus predecessores. Mas é com Friedrich Schiller, em dois ensaios publicados entre 1793 e 1795 (Do sublime e Sobre o sublime, respectivamente), que a noção retorna à arte, e recebe a forma pela qual seria adotado no Romantismo.

Assim, a experiência do sublime, tal como já aparecia em Burke, proviria do contato com um objeto sublime - "tudo que seja de algum modo capaz de incitar idéias de dor e de perigo, isto é, tudo o que seja de alguma maneira terrível ou relacionado ao terror". ${ }^{145}$ Para Kant, esse objeto seria necessariamente um elemento ou fenômeno da natureza grandioso e atemorizante (o oceano, o céu, uma cadeia de montanhas, um abismo, uma tempestade, etc ${ }^{146}$ ), diante do qual o homem, em sua sensibilidade física, se sente inferior, mas, ao mesmo tempo, se esforça em superá-lo por meio de suas idéias, transcendendo sua condição humana. ${ }^{147}$ Essa não é tarefa fácil, mas o desafio e o risco é o que atrai: Em lugar de senti-la [a Natureza] como problema resolvido, à maneira do neoclássico, o romântico adora-a e renega-a sucessivamente, sem desprender-se do seu fascínio nem pacificar-se ao seu contato. ${ }^{148}$ Mesmo ameaçando sua existência material, o homem, por um exercício do espírito, se revela maior, elevando-se em sua liberdade moral.

Frente ao objeto sublime, de acordo com a perspectiva kantiana, podem se manifestar dois impulsos: o de conhecimento (quando há uma inadequação entre o objeto e a capacidade humana de percebê-lo através dos sentidos, busca-se compreendêlo através de um esforço máximo da imaginação), e o de autoconservação (pois o homem, ao confirmar a invencibilidade física do objeto, busca uma resistência mental, ideal, contra ele, subestimando sua força e afirmando sua superioridade em um plano abstrato). No segundo caso, o sujeito deixaria de temer pela própria vida, já que apenas o corpo sucumbe, e não o pensamento. Dentro da educação estética do indivíduo

\footnotetext{
145 BURKE, 1993, p. 48.

$146 \mathrm{Ou}$, nas palavras do próprio Kant: Rochedos audazes sobressaindo-se ameaçadores, nuvens carregadas acumulando-se no céu, avançando com relâmpagos e estampidos, vulcões em sua inteira força destruidora, furacões com a devastação deixada para trás, o ilimitado oceano revolto, uma alta queda d'água de um rio poderoso, etc (...) de bom grado denominamos esses objetos sublimes porque eles elevam a fortaleza da alma acima de seu nível médio e permitem descobrir em nós uma faculdade de resistência de espécie totalmente diversa, a qual nos encoraja a medir-nos com a aparente onipotência da natureza. (KANT, 2012, p. 109)

147 "Não pode haver momento sublime sem o implícito e dialético endosso das limitações humanas. ”(WEISKEL, 1994, p. 73)

${ }^{148}$ CANDIDO, 2009, p 349.
} 
romântico, ${ }^{149}$ alcançar a experiência do sublime seria altamente desejável pois, colocando em conflito a sensibilidade e a razão, ele exercitaria sua humanidade.

Ou seja, muito além do simples desejo de épater le bourgeois, o Romantismo buscou a experiência do sublime para seu próprio aprimoramento filosófico. O contato com os dois tipos de objetos, "belos" e "sublimes", passava a ser considerado indispensável, pois exercitavam as duas naturezas humanas, a sensível e a racional (os primeiros, harmonizando-as; os segundos, as colocando em conflito), possibilitando ao homem descobrir seu poder, sua plenitude.

A novidade inserida por Schiller no debate moderno (retomando, de certa maneira, Longino e Burke) é o entendimento de que o objeto sublime não precisa ser necessariamente um elemento ou fenômeno real da natureza - tal como alegava a crítica kantiana ${ }^{150}$-, podendo ser também, sua representação. ${ }^{151}$ Sem precisar subjugar o corpo e sofrer violência, ainda seria possível vivenciar o objeto por meio da arte. Porque imita a aparência, mas não a realidade, essa imagem coloca o homem frente ao sublime, mesmo que de segunda mão, fornecendo igualmente uma experiência legítima.

Quando o cadáver decomposto aparece na literatura, ele representa a morte em toda sua platitude, isto é, como total dissolução do corpo, como um fim, e não como esperança de salvação. Essa morte absoluta, intangível, é grandiosa por sua inexplicabilidade. A vida que acaba, misteriosamente, tal como inicia, é um evento sublime, temível. O último suspiro talvez seja o ato humano mais assombroso de todos. E, contudo, nada é mais fascinante do que o segredo da existência. Nada há que seja tão repulsivo e tão atraente ao mesmo tempo. Essa mistura de sentimentos é própria da experiência sublime e provoca deleite, ou, um horror deleitoso, segundo Burke. Ainda de acordo com o autor inglês, nesse sentido, a morte, ou a idéia da morte, é a maior fonte desse sentimento, uma vez que é causa da paixão mais profunda e intensa, aquela ligada à autopreservação. E ela não seria despertada apenas pela imagem do morto, mas por tudo que potencialmente possa gerar o medo da morte, presente nas figuras da falta

\footnotetext{
${ }^{149}$ O projeto de uma educação estética do homem através das experiências do belo e do sublime é proposta de Schiller.

150 "não se tem de apresentar o sublime em produtos de arte (...) mas na natureza bruta, simplesmente enquanto ela contém grandeza." (KANT, 2012, p. 99)

${ }^{151}$ Daí o interesse notável dos artistas do início do século XIX pela pintura de paisagem, em detrimento de outros temas. Como caminho para o sublime, essas obras visavam os mesmos efeitos grandiosos e simbólicos da natureza, expressando sentimentos e estimulando idéias. Não por acaso, o termo romântico era aplicado à essa pintura paisagística.
} 
absoluta (o vazio, a escuridão, o silêncio, a solidão) ou da vastidão inatingível (o oceano, o céu, um abismo, a natureza exuberante e ameaçadora).

Schiller não negligenciou a importância da morte propriamente dita como objeto sublime. No entanto, afirma que a religião se configura como a instância de segurança contra ela e a fé na imortalidade faz com que os homens não se sintam mais ameaçados (sendo que a ameaça é condição necessária para ocorrer o sublime). Como já foi comentado, porém, uma das transformações mais emblemáticas das mentalidades no período em que o autor alemão escreve foi, justamente, a da profunda secularização da sociedade - e nesse sentido, não é por acaso que a Natureza, em sua acepção pelo sublime, seja caracterizada com os predicados antes atribuídos à divindade, substituindo-a (atemorizante, grandiosa, infinita, etc).

Se a religião não oferece mais consolo contra a morte, ela pode ser considerada o objeto sublime por excelência: diante dela, não há saída. O homem sem fé sabe de sua fragilidade, sabe que não há escapatória e só resta ser subjugado fisicamente.

Schiller, no artigo Sobre o sublime, declara: "O homem é o ser que quer". A vontade é o que caracterizaria o ser humano; não agir de acordo com ela é uma violência. Segundo o autor, quando o homem é obrigado a algo que não quer, sua condição humana é anulada.

O indivíduo moderno, longe da fé e da religião, é aquele que não quer morrer. A morte uma violencia a que está obrigado, sendo portanto o grande obstáculo da afirmação de sua vontade e de sua humanidade. Nada o afasta dela, nem mesmo a religião, pois para esse sujeito racional, não existe vida post-mortem. Haveria meio de vencer esse medo de morrer, ainda que conceitualmente? Os teóricos do sublime tendem a apontar a arte como um potente antídoto contra esse medo. A arte que expõe o cadáver, uma imagem que remete diretamente à ameaça, à dor e à consciência do desaparecimento, de certa forma também faz dele um objeto de fruição, alçando-o ao patamar do sublime. Dessa forma, o observador pode superar o que o apavora, enfrentando sua representação. ${ }^{152}$ "Entre as coisas que o sublime nos capacita a desprezar está a própria vida, "153 pois nos libera da condição trágica da existência.

\footnotetext{
152 Daí também que, de um ponto de vista psicanalítico, essas imagens podem ser interpretadas como roteiros que têm a função de estruturar a ansiedade, revelando o esforço humano de organizar o horror através de uma forma legível. Nesse sentido, frente à ameaça de dissolução absoluta do ser, as
} 
Na história da consciência literária, o sublime ressurge à medida que Deus exime-se de uma participação imediata na experiência dos homens. " romântico aparece justamente quando o poder de Deus em dar sentido a vida se ausenta. E, como se sabe, a relação dos poetas românticos com a religião é complexa, para não dizer confusa. Talvez em nenhum outro aspecto, a máxima "existem tantos romantismos quanto românticos" se expresse tão plenamente. Uma parte, provavelmente a maior, considerava-se religiosa, indo de encontro à tendência atéia de sua época. Muitos não eram contra a religião per se, em particular o cristianismo, mas contra a Igreja, a fé instrumentalizada, preferindo praticar um misticismo sem filiação ou cujas raízes estariam nas crenças primitivas. Outros tantos, ainda que se considerassem ateus, escreviam livremente sobre Deus. Segundo Octávio Paz:

Cada poeta inventa sua própria mitologia e cada uma dessas mitologias é uma mescla de crenças díspares, mitos desenterrados e obsessões pessoais. Quase todos os grandes românticos foram espíritos religiosos, porém qual foi realmente a religião de Hölderlin, Blake, Coleridge, Hugo, Nerval? A mesma pergunta poderia ser feita aos que se declararam francamente irreligiosos. O ateísmo de Shelley é uma paixão religiosa. Negação da religião: paixão pela religião. ${ }^{155}$

Apesar da ambígua relação com a religião, o vocabulário teológico transbordava para as obras, independente de seu credo e, por vezes, esvaziadas de seu conteúdo religioso. Sobre isso, comenta Charles Rosen:

O que os românticos descobriram foi a possibilidade de privar as formas de sua significação original e de lhes conferir um novo sentido quase diametralmente oposto. $\mathrm{O}$ que eles buscavam era a tensão entre o novo sentido e o inveitável resíduo do velho. (...) A batalha dos primeiros românticos

\footnotetext{
fantasmagorias do macabro, por mais sinistras que sejam, teriam uma função consoladora: afinal, as figurações dos corpos mortos estão sempre aquém do "pavor do informe, daquilo que abole todas as categorias, isto é, da homogeneidade absoluta da morte."(Mezan In: NOVAES, 1988, p. 466. )

${ }^{153}$ WEISKEL, 1994, p. 145.

${ }^{154}$ WEISKEL, 1994, p. 17.

${ }^{155}$ PAZ, 1984, p. 67.
} 
contra o ateísmo era essencialmente contra a nova tirania autoritária, religiosa, do pensamento mecanicista. ${ }^{156}$

O que, por vezes, era denominado Deus, Paraíso, Infinito, ou qualquer outro conceito de transcendência, referia-se a essa zona de resistência, um refúgio, ainda que temporário. Esse esvaziamento da linguagem religiosa ${ }^{157}$ (poderíamos dizer: essa ironia), é reveladora da angústia romântica. ${ }^{158} \mathrm{O}$ gosto pelo macabro, a tensão em direção à morte física, resulta no que Béguin chama de um ardente desejo de dissolução, que vê na aniquilação do corpo um retorno à natureza. Ao contemplar o grande ciclo de vida e a morte que tudo comporta e organiza, o poeta reconhece uma união física com o mundo, na qual matéria reencontra matéria.

$\mathrm{Na}$ solidão de um mundo racional que atomiza o sujeito, diante de todas as coisas e dos outros, essa é a resposta ao desejo de reintegração ao conjunto, ao universal. A experiência sublime do macabro contorna o caráter trágico da existência, fazendo da morte fonte de prazer e admiração, proporcionando a elevação espiritual diante da imagem da dissolvição orgânica. Daí a retomada do imaginário macabro ir além da mera voga medievalista, adequando-se aos princípios ideológicos do Romantismo.

\section{O abjeto}

Enquanto a moral burguesa, em seu empenho de circunscrever o privado, elevava o pudor à escala máxima dos valores de convívio social, fazendo com que as práticas naturais do corpo, realizadas durante séculos em público, fossem cada vez mais

\footnotetext{
${ }^{156}$ ROSEN, 2004, p. 55-63.

${ }^{157}$ prática que poderia ser observada até no Romantismo brasileiro. Segundo Antonio Candido: A religião foi desde logo reputada elemento indispensável à reforma literára [introduzida pelo Romantismo] não apenas por imitação dos modelos franceses, mas porque, opondo-se ao temário pagão dos neoclássicos, representava algo oposto ao passado colonial. (2009, p. 334).

${ }^{158}$ Não se trata aqui, logicamente, de defender a idéia de que todos os românticos eram ateus ou, ainda, que sua devoção religiosa fosse um engodo. Trata-se de mostrar que a perda da fé foi um movimento generalizado na época, tendo como reação, até mesmo, a atitude contrária: um fervor extremista e obsessivo - ou mesmo a descrença absoluta. A ênfase no macabro, ou seja, no dejeto corpóreo, é sintomático das duas possibilidades.
} 
escondidas, o Romantismo escancarava sua verve provocadora, expondo novamente o cadáver a uma sociedade que faz de tudo para tabuizar o fim da vida.

Absorto em meditações, inflado de uma solidão infinita, o homem romântico contempla a tragédia da vida que é a morte, sublime, imensa, o Nada absoluto porque é fim, o Todo absoluto porque é conjunção com a Natureza. ${ }^{159}$ A menção à dissolução do corpo expressa ambas concepções, daí o desconforto causado pelo gosto pelo macabro, em obras como os estudos anatômicos de Gericault ou a descrição dos elementos do apodrecimento do corpo na prosa e na poesia. Pois tanto quanto sublime, o cadáver é da ordem do abjeto. Mas, diferentemente da elevação espiritual do sublime, que nos transcende ao mesmo tempo que nos escapa, o abjeto é o irredutível, um resíduo inevitável que coloca em xeque o "eu", convulsionando a própria existência. Seligmann-Silva destaca que:

ambos conceitos, sublime e abjeto, lidam com o inominável e sem-limites, mas falando esquematicamente, o sublime remete ao sublime espiritual - e o abjeto ao nosso corpo. Ambos são conceitos de fronteira marcados pela ambiguidade e que nos abalam: o abjeto nos remete para baixo - cadáver vem do latim cadere, cair: um corpo que cai. ${ }^{160}$

Julia Kristeva considera ainda que l'abject est bordé de sublime. Ce n'est pas le même moment du parcours, mais c'est le même sujet et le même discours qui les font exister. Car le sublime, lui non plus, n'a pas d'objet (...) le sublime est un en plus qui nous enfle, qui nous excède et nous fait être à la fois ici, jetés, et là, autres et éclatants. ${ }^{161}$ Assim também opera o abjeto, segundo a autora, pois como o sublime, ele é uma qualidade do objeto: celle de s'opposer à "je”. ${ }^{162}$ E porque coloca em conflito

\footnotetext{
${ }^{159}$ O sujeito romântico parece só ter condições de subsistir quando se passa em alguma dimensão temporal: no passado da poesia nostálgica, no futuro da poesia utópica. Mas fechado na sua imanência, e na medida em que a Natureza deixou de ser a sua grande testemunha, ele cai na angústia da finitude, $e$ as suas figuras descolam do mito da queda. (BOSI, In: GUINSBURG, p. 248).

${ }^{160}$ SELIGMANN-SILVA, 2005, p. 40.

${ }^{161}$ KRISTEVA, 1983, p. 19.

${ }^{162}$ Ce n'est donc pas l'absence de propreté ou de santé qui rend abject, mais ce qui perturbe une identité, un système, un ordre. L'entre-deux, l'ambigu, le mixte. (KRISTEVA, 1983, p. 11-2)
} 
essa relação do "eu" consigo mesmo, ele age como um boomerang indomptable, un pôle d'appel et de répulsion (...) Sursaut fasciné qui m'y conduit et m'en sépare. ${ }^{163}$

O cadáver, cet autre que je suis et que je n'attendrai jamais, ${ }^{164}$ seria, portanto, o "cúmulo do abjeto", ${ }^{165}$ segundo Kristeva, isto é, sua manifestação mais privilegiada e evidente, pois ele bouleverse plus violemment encore l'identité de celui qui s'y confronte comme un hasard fragile et fallacieux. Esse corpo sem alma, que apodrece e expõe sua infame materialidade é lieu privilegié du mélange, de la contamination de la vie par la mort, de l'engendrement et de la fin $^{166}$, relembrando todo o tempo o incômodo do resíduo. A correspondência entre o abjeto (o asqueroso) e o morto é tão grande que os termos se confundem: no Brasil, pelo menos desde o século XIX (e até hoje), verifica-se o emprego da palavra "nojo" com o sentido de "luto".

Mas a destruição da carne é também um princípio de elevação da alma, vide o martírio de santos e flagelantes, que impõem ao corpo castigos severos em nome da transcendência. Aniquilar o corpo físico ou expor-se aos suplícios da carne: eis a regra dessa estranha vontade de metamorfose, única capaz, diziam, de efetuar a passagem do abjeto ao sublime. 167 "Aniquilar" de fato ou na arte: falar da decomposição do corpo, que desencadeia o sentimento do abjeto, leva também à sua elevação, como objeto sublime. Quando se apropria das imagens do abjeto, a arte, segundo Kristeva, os purifica, já que controla sua força através da experiência catártica pela representação. ${ }^{168}$ As representações que engendram o asco podem ser dissolvidas em sentimentos agradáveis por meio da recordação de que se trata de um engano artístico. Ainda com Kristeva: Les amateurs de cadavres, adorateurs inconscients d'un corps sans âme, seront alors les représentants par excellence des religions ennemies, désignées par leurs cultes meurtriers ${ }^{169}$ - os românticos de certa maneira recuperam essa noção, esse culto pagão aos mortos.

\footnotetext{
${ }^{163}$ KRISTEVA, 1983, p. 9-10.

${ }^{164}$ KRISTEVA, 1983, p. 175.

${ }^{165}$ Le cadavre - vu sans Dieu et hors de la science - est le comble de l'abjection. (KRISTEVA, 1983, p. 175)

${ }^{166}$ KRISTEVA, 1983, p. 174.

${ }^{167}$ ROUDINESCO, 2008, p. 20.

${ }^{168}$ KRISTEVA, 1983, p. 24.

${ }^{169}$ KRISTEVA, 1983, p. 128.
} 


\section{Vida e arte}

O gosto pelo macabro se manifestava na vida e na arte, e as fronteiras entre uma e outra são tênues entre os românticos. No prefácio de L'âne mort, onde faz a sua crítica à crítica literária de então (a mesma da qual falava Gautier), Jules Janin sugere que todo autor fale de coisas que conhece empriricamente ("avant de parler d'une chose, il faut la voir de ses yeux, la toucher de ses mains." ${ }^{170}$ ) - o que não deixa de ser uma grande ironia em uma novela de horror, um típico "romance-carniça". Assim, se vous parlez d'un mort, recomenda Janin, allez à l'amphithéâtre; d'un cadavre, déterrez. le cadavre; des vers que le rongent, ouvrez le cadavre ${ }^{171}$. Apesar de bem-humorado, esse seria o tipo de conselho levado a cabo por uma porção de românticos - essa gente que tomava certas fantasias mórbidas tão a sério que queria traduzi-las em vida vivida, lembra Mario Praz. ${ }^{172}$ A vantagem seria, ao menos, de fazê-los se acostumar com a idéia da própria morte: Cette triste poétique de tombeaux et de cadavres a cela d'affreux, qu'elle vous habitue bien vite même à votre propre cadavre. ${ }^{173}$

Não é à toa que histórias relacionadas à invasão de cemitérios e à profanação de sepulturas, com o ordinário propósito de farrear entre os mortos, façam parte da biografia de alguns poetas do período, alguns dos mais ilustres, e sejam dadas como verdadeiras até hoje. No Brasil, talvez a mais exemplar seja a lenda da "Coroação da Rainha dos Mortos".

No fatídico evento, conta-se que o grupo que se auto-intitulava "Sociedade Epicuréia", formado por poetas como Álvares de Azevedo, Bernardo Guimarães, Aureliano Lessa, entre outros ${ }^{174}$, todos admiradores de Byron e ainda estudantes da escola de Direito, resolve, numa noite de bebedeira ${ }^{175}$ (evento que parecia ser bastante usual no cotidiano dos jovens acadêmicos ${ }^{176}$ ), invadir um dos cemitérios públicos do

\footnotetext{
${ }^{170}$ JANIN, 1861, p. 10.

${ }^{171}$ Idem, ibidem.

${ }^{172}$ PRAZ, 1996, p. 127.

173 JANIN, 1861, p. 54.

${ }^{174}$ Ubiratan Machado também inclui Fagundes Varela no bando. (2010, p. 226)

175 Se a história da "Coroação..." não passa de lenda, sabe-se ao certo que eram comuns as reuniões entre os estudantes em suas repúblicas, encontros sempre regados a álcool e enfumaçados pelos cigarros e charutos. Conversava-se sobre tudo, recitava-se poesias, discutia-se política, cantava-se, ceiava-se e "os mais ousados introduziam prostitutas". Quem conta em detalhes é Ubiratan Machado (2010, p. 201).

${ }^{176}$ Seguimos com Ubiratan Machado, que comenta a respeito da Sociedade Epicuréia: Para suas farras, os estudantes reuniam-se na Chácara dos Ingleses ou em outro arrabalde afastado, dominados pela mais
} 
centro da cidade de São Paulo. No meio da algazarra e da excitação por estarem entre os sepulcros, eles decidem realizar uma cerimônia para coroar uma "Rainha dos Mortos". Escolhem uma sepultura recém coberta, retiram a terra, abrem o caixão, esvaziam-no do defunto que o ocupava e seguem em direção à casa da prostituta Eufrásia, de que eram clientes. Aproveitando a sonolência de sua vítima, agarram-na e colocam-na à força dentro do esquife. Seguem, novamente, em direção ao cemitério.

Lá, enquanto buscavam o melhor lugar para a cerimônia, um dos jovens encontra o túmulo de uma mocinha a quem teria dedicado grande estima, e que havia falecido há pouco. Entorpecido de saudade, paixão, álcool e sabe-se lá mais o quê, o poeta cavou com as mãos até encontrar o caixão que, ao ser aberto, revelou o corpo nu da amada. Sem atinar, abraça-o e beija a boca carcomida. Ao sentir o odor de podredume, acorda do transe e se desespera com a visão da carne roxa e gélida, corroída pelos vermes que ali se refestelavam.

Longe de aterrorizar, o incidente teria excitado ainda mais o grupo, que se preparava para o festim da Rainha. Um deles foi designado seu noivo e a desposaria na frente dos outros. O caixão com Eufrásia dentro foi, então, depositado dentro de uma cova. Ao abrirem-no, estava a prostituta pálida, trêmula e com os olhos esbugalhados. O "noivo" avança sobre ela. A partir daí, nas palavras de Pires de Almeida, um dos autores responsáveis por espalhar a lenda, "o banquete de bodas começou escandaloso de danças macabras e de recitações características dessa escola poética e literária”. De súbito, gritos de horror do noivo apavorado irrompem de dentro da cova: “- Eufrásia está morta! Está morta!” Os jovens se olharam assustados por um instante e, em seguida, estourando em gargalhadas, repetiram “- Está morta! Está morta!”, e continuaram a festa. ${ }^{177}$

avassaladora morbidez, a fim de corresponder ao comportamento satânico dos eprsonagens de Byron. cobriam as paredes de tapetes negros, decotados com emblemas fúnebres em branco: esqueletos, coxas, tíbias. Os candelabros eram velados por quebra-luzes funéreos. Nos quartos, as cams eram colocadas sobre catafalcos, entre círios. (2010, p. 223)

${ }^{177}$ Pires de Almeida (cujo livro A escola byroniana no Brasil trata de um conjunto de artigos publicados entre 1903 e 1905) e Ubiratan Machado (em A vida literária no Brasil durante o Romantismo) são dos autores que relatam o episódio como verdadeiro. No entanto, a falta de registros oficiais (como um inquérito policial ou um processo-crime no Ministério Público, nem mesmo um documento que comprove o enterro da prostituta Eufrásia, como um livro de Registros) sobre o ocorrido levanta a suspeita de que não passe de ficção ou, ao menos, de uma versão exagerada de uma noitada mais animada do grupo. Sustenta essa tese, por exemplo, Vicente de Paulo Vicente de Azevedo em artigo publicado em 20 de março de 1965, pelo Estado de São Paulo (Suplemento Literário, p. 4). 
Para além do anedótico, esse episódio é significativo, não importa se real ou ficcional. Vale lembrar que, aparentemente, todo o imaginário macabro, o medieval e o romântico, parece ter tido seus ecos em terras tropicais, não apenas nas peripécias de nossos jovens poetas, mas também em sua obra literária. Afinal, os nossos autores liam o Romantismo europeu, em especial o francês, mas também o português e o espanhol, e alguns ingleses, tanto nas (escassas) traduções como nos originais. ${ }^{178}$

Abundam exemplos dessa influência macabra em Álvares de Azevedo, por exemplo, nosso romântico maior. Macário, um de seus triunfos literários, é homônimo ao santo frequentemente mencionado pelos autores que pesquisaram a origem do termo "macabro". ${ }^{179}$ Sua Noite na taverna é claramente filiada à linhagem das novelas góticas ("Estamos sem dúvida ante um produto do romance negro, mais particularmente da modalidade que os franceses chamam de 'frenético"," - sentencia Antonio Candido ${ }^{180}$ ). Os relatos dos cinco ébrios em volta da mesa do bar confrontam o leitor com o incesto, a necrofilia, o fratricídio, o canibalismo, a traição e o assassinato: experiências-limite cuja função para os românticos era mostrar os abismos virtuais e as desarmonias da nossa natureza, assim como a fragilidade das convenções. ${ }^{181}$ E não são exclusividade de Noite na taverna, também representadas perfeitamente em Um cadáver de poeta, poema no qual o jovem defunto é abandonado por dias em uma estrada, sem que ninguém saiba seu nome ou sinta sua falta:

Morreu um trovador! morreu de fome...

Acharam-no deitado no caminho:

Tão doce era o semblante! Sobre os lábios

Flutuava-lhe um riso esperançoso;

E o morto parecia adormecido.

\section{$(\ldots)$}

Todos o viram e passaram todos...

Contudo era bem morto desde a aurora.

Ninguém lançou-lhe junto ao corpo imóvel

Um ceitil para a cova!... nem sudário! ${ }^{182}$

\footnotetext{
${ }^{178}$ Imitadores de Byron, Musset, Espronceda, João de Lemos, Soares Passos, Mendes Leal, participam por aí da corrente geral do Romantismo europeu, a que deram todavia matizes expressivos do nosso modo de ser. (CANDIDO, 2009, p. 469)

${ }^{179} \mathrm{O}$ que pode ser ou não uma coincidência. Não foi encontrado nenhum estudo que relacionasse o título da obra e seu personagem a São Macário. No entanto, a aproximação é evidente (ver capítulo 1 desta tese, página XX).

${ }^{180} \mathrm{Em}$ A educação pela noite (1989, p. 17).

${ }^{181}$ CANDIDO, 1989, p. 17.

${ }^{182}$ AZEVEDO, 1996, p. 132.
} 
Segundo Alfredo Bosi, fingindo ironicamente que partilha com o leitor o desprezo burguês pelo poeta e pela poesia, Álvares expõe a situação ambígua desse homem que vive de produzir palavras, sonhos, imagens, sentimentos. ${ }^{183}$ Afinal, "De que vale um poeta - um pobre louco / Que leva os dias a sonhas - insano / Amante de utopias e virtudes / E, num tempo sem Deus, ainda crente?" O poeta, nessa sociedade utilitarista, é um anacrônico, não serve para nada quando vivo, constrange quando morto: "Por que há de o vivo que despreza rimas / Cansar os braços arrastando um morto". Seu trabalho não é reconhecido, ele leva uma "vida impura”, "onde arquejou de fome... sem um leito!". Ninguém lamentou sua passagem ("Ninguém chorou por ele"):

Ninguém ao peito recostou-lhe a fronte Nas horas de agonia! Nem um beijo Em boca de mulher! nem mão amiga Fechou ao trovador os tristes olhos! ${ }^{184}$

Viveu sem um leito e permanecia assim seu cadáver ("nem um sudário", "Nem túmulo nem cruz!”, “Pobretão! Não valia a sepultura!”), largado no meio do caminho. Seu apodrecimento aborrece os que passam, incluindo figuras importantes como o Rei e seu séquito (apesar de "rei devoto", chega a perguntar ao seu capelão "E não enterram / Esse homem que apodrece, e no caminho / Assusta-me o corcel?"). A carruagem do bispo solavanca ao passar pela "humana resistência". Seu cocheiro esclarece o incidente - e vê-se a diferença do tratamento dado ao magnânimo eclesiástico e ao infeliz trovador: "Perdoe Vossa Excelência Eminentíssima, / É um pobre diabo de poeta, / Um homem sem miolo e sem barriga / Que lembrou-se de vir morrer na estrada!" Todos que cruzam com o poeta-cadáver incomodam-se com sua presença (só assim ela foi notada!), cheiro e aparência, mas nada fazem a não ser desviar ou empurrá-lo para fora do caminho. Por fim, uma figura misteriosa surge para honrar o vate e cavar-lhe uma fossa - uma mulher em trajes masculinos, que se mata em seguida, ingerindo veneno.

Seguindo a mesma sintonia mal de vivre, a cena do abandono do cadáver se repete no Miserrimus, de um inusualmente melancólico Gonçalves Dias, ${ }^{185}$ no qual o

\footnotetext{
${ }^{183}$ BOSI in: GUINBURG, 1993, p. 249.
}

${ }^{184}$ AZEVEDO, 1996, p. 132. 
protagonista perambula errático por um cemitério, à procura da lápide da mãe: “Aqui ali - além - eram sepulcros; / E o nome de sua mãe, sequer não pode / Dos nomes conhecer de tantos mortos." O sujeito, no meio da busca, tomando pela tristeza, desfalece, vindo a morrer entre as sepulturas: "E só no seu morrer, qual só na vida,/Na terra se estendeu; nem dor, nem pranto/Tinha no coração que era já morto!'” E, assim como o poeta de Álvares de Azevedo, seu cadáver permanece ali, em dissolvição pública, até que alguém mais enfastiado pela vista, "com o pé", o empurra para dentro de uma fossa:

E alguém, que ali passou, vendo um cadáver

De sânie e podridão comido e sujo,

Co'o pé num fosso o revolveu; - e terra

Caída acaso o sepultou p'ra sempre. ${ }^{186}$

O Pesadelo de Castro Alves, de 1863, expressa o lado macabro do poeta baiano, mais conhecido pela sua adesão à causa escravocrata. Como em uma novela gótica, inicia-se a narrativa em atmosfera tipicamente romântica, uma "noite perfumada $e$ lânguida", a natureza participante da sucessão de fatos como um personagem (a brisa e a folhagem, o branco orvalho nos galhos, flores que supiravam, a sensual brisa do mar, as nuvens brancas como garças). Nessa paisagem, o casal apaixonado se encontra - ele, um "trovador ardente", "bardo formoso", Joseph, de tez pálida e cabelos pretos ("Ele era belo"); ela, Laura, a "virgem fascinante e bela", de cabelos desordenadamente trançados. Na segunda parte do poema, a natureza acompanha a mudança de tom; prenunciando a aparição do assassino (Jorge, "o libertino", de "fronte macilenta", usando capote e sombreiro, bebendo cognac e fumando), em uma cena noturna ("noite tristonha e friorenta"), sem estrelas e em que "caía fria chuva", só se ouviam as aves notívagas, "regeladas", berrarem na escuridão. O mar, agora, não era mais suave e indolente, mas "sinistro e tétrico", e rugia. Joseph, após os momentos passados com a amada, cruza o caminho de Jorge, caindo em sua emboscada. Seu "grito agudo" (e "um grito somente") foi ouvido por Laura, que o reconhece e, apavorada, tremendo de terror, sai em sua busca.

${ }^{185}$ Segundo Antonio Candido, Gonçalves Dias distinguiu-se da chamada segunda geração romântica pela ausência de pessimismo e deliberada resistência à intemperança sentimental. O "mal do século" apareceria ocasionalmente em sua obra. (2009, p. 401)

${ }^{186}$ DIAS, 1998, p. 578. 
Próximo dali, Joseph jaz. É a quarta parte do poema e a natureza novamente emoldura a ação. Numa paisagem desoladora, "entre ciprestes" cemiteriais, o vento gélido balança as árvores. Ali, "Num esquife entreaberto está deitado /Um cadáver de moço abandonado."

Veja-se como a morte, aqui, também simboliza a solidão infinita de um jovem poeta, e de sua própria condição social ("entregue às intempéries", "sem amigos"). "Sonhador", cantou "os sentimentos puros do mundo," mas na hora derradeira, não tem quem chore por ele:

E entregue às intempéries... sem amigos

Sem ter quem vá ali chorar um pranto. $\mathrm{Tu}$, que cantaste os sentimentos puros, Qu'encontraste no mundo um doce encanto, Tu dormes, sonhador, já macilento, Entregue aos vermes vis, posto ao relento. ${ }^{187}$

Finalmente, Laura encontra o noivo. A agonia a enloqueceu; ela se aproxima do corpo "rindo e soluçando", "c'um rir entre medonho e entre formoso":

Junto ao verde cadáver ajoelhou E com os lábios ardentes o beijou.

Deitada ao seu lado, brincando com os seus cabelos e entoando baixinho antigas canções, beijando-o amorosa e insistentemente, a jovem também morre.

Como em Castro Alves, a temática da escravidão e os motivos políticos eram uma constante na obra do baiano Lúcio de Mendonça, este, aliás, admirador daquele. ${ }^{188}$ Em seu poema $A$ besta morta, é um velho cativo negro que jaz abandonado na senzala. Novamente, a situação é agravada pela decomposição dos despojos. O corpo, deformado pelo labor forçado, enfim encontra a paz após o óbito:

Cruza no peito as mãos roidas do trabalho.

Sobram do cobertor os grossos pés informes.

- Dorme, descança, emfim, que do somno em que dormes Já não póde accordar-te a sanha do vergalho!

\footnotetext{
${ }^{187}$ ALVES, 1997, p. 387.

${ }^{188}$ Tendo escrito poemas em suas homenagem, quando de sua morte. (CANDIDO, 2009, p. 602)
} 
Como unica oração que tua alma proteja,

Por sobre a podridão de tua bocca fria

Vibra no ar zumbindo a mosca de vareja... ${ }^{189}$

O angustiado baiano Junqueira Freire, cuja vocação para a vida no claustro era sempre posta em xeque em sua poesia, recorria frequentemente aos elementos da dissolução do corpo próprio, emulando a locução latina do cupio dissolvi (quase uma obsessão depois, entre os simbolistas), como em “Morte (Hora de delírio)", publicado nas "Contradições poéticas". Apesar de apresentada como "pensamento gentil de paz. eterna" nas três primeiras estrofes, evocada e chamada de "amiga", resta depois de sua chegada o tumulto da corrupção, o caos da matéria se desfazendo - em versos muito condizentes com seus pares românticos. O resto humano se incorpora à plantinha que "talvez" brote dessa organicidade poluente; nela, renasceriam partes do poeta, resíduos de "alma, sentimento e corpo". Renovam-se, assim, o ciclo da vida e da natureza.

Miríades de vermes lá me esperam Para nascer de meu fermento ainda. Para nutrir-se de meu suco impuro, Talvez me espera uma plantinha linda.

Vermes que sôbre podridões refervem, Plantinha que a raiz meus ossos ferra, Em vós minha alma e sentimento e corpo Irão em partes agregar-se à terra.

E depois, nada mais. Já não há tempo, Nem vida, nem sentir, nem dor, nem gôsto. Agora o nada, - êsse real tão belo Só nas terrenas vísceras deposto. ${ }^{190}$

O tema se repete no poema $O$ arranco da morte ("Pesa-me a vida já", "Ah já não pode o espírito cansado / Sustentar a matéria", "Eu morro, eu morro", "Vai meu corpo dissolver-se em cinza”, "o corpo que foi o meu! que lodo impuro / Caiu, uniu-se à terra") ou ainda em Aos túmulos ("Tua missão, minh'harpa, é grande, é grande: / Sagremo-nos à morte. / Aos túmulos, aos túmulos, minh'harpa") Na ocasião do falecimento de um frei do monastério beneditino em que viveu e que viu agonizar,

\footnotetext{
${ }^{189}$ MENDONÇA, 1902, p. 157.
}

${ }^{190}$ FREIRE, 1944, p. 72-3. 
escreve desde o ponto de vista do cadáver no caixão ("A morte no claustro", de 1851, publicado nas "Inspirações do claustro"):

Em solene calada distinguiras O pisar do pilão pesado e ouco Por estóicos coveiros manejado. Depois o baque da sonora lápida, Que fecha - esmaga o pútrido cadáver.

Depois talvez uma oração ainda Dos lábios do cristão baixou sôbre ele.

Depois nada mais ali - fora o silêncio. ${ }^{191}$

E depois de findos os serviços, Freire contempla a perspectiva da sua própria morte no monastério, no mesmo sepulcro do velho frei, com que dormirá pela eternidade:

N'estes claustros, aqui, talves, - quem sabe?

Talvez n'este sepulchro immundo mesmo, Após alguns minutos mais escassos

D'esse meu vegetar insulso e morno,

Me pilarão - triturarão meus ossos

Deshumanos tumbeiros. - Eu comtigo,

Podre cadaver, dormirei eterno,

Feito meu corpo em terra e cinza e nada. ${ }^{192}$

Mesmo o autor de A Confederação dos tamoios, Gonçalves de Magalhães, se deixara inspirar pelos temas tumulares. Nos Cânticos Fúnebres (coletânea de poemas compostos entre 1834 e 1864), o poeta parece tentar replicar o estilo dos românticos mais "modernos", ${ }^{193}$ como Álvares de Azevedo, daí a insistência no linguajar macabro, que não aparece no restante de sua obra. Conforme Antonio Candido, Magalhães soube transmitir de modo convincente o macabro cinismo com que refere a sua impregnação de morte - transfundida na terra, no ar, no pão, na carne; relegada a uma espécie de

\footnotetext{
${ }^{191}$ FREIRE, 1944, p. 181.

${ }^{192}$ FREIRE, 1944, p. 180.

193 ou da chamada "segunda geração", termo usado corriqueiramente, mas um tanto polêmico. Por isso, a divisão do romantismo brasileiro em três gerações não é utilizada nesse trabalho.
} 
rotina trágica, ${ }^{194}$ que se acentua na fala do coveiro, que diz, como num lamento: "Vivo c'os mortos, / na cova os ponho, / Entre eles durmo,/ Com eles sonho", ou ainda: "No pão que como,/ No ar que respiro,/ Na água que bebo,/ A morte aspiro", e assim por diante. O contato estreito e diário com a morte o leva a deduzir a trivialidade da vida: "Ricos e pobres, / Todos virão, / Dormir no leito / Da podridão”. Um "podre cadáver / Qu causa horror" é o que resta de cada um, mesmo daqueles que mais se ama:

Ternos amantes, Pais extremosos, Esposos caros, Filhos saudosas, Vêde o que resta Do vosso amor: Podre cadaver, Que causa horror! ${ }^{195}$

No caso específico das Danças Macabras, o gênero que foi o maior propagador do macabro medieval, pode-se encontrá-las em, pelo menos, dois textos dos mais significativos: no poema narrativo O Conde Lopo (de 1848), de Álvares de Azevedo, e no conto A dança dos ossos (1871), de Bernardo Guimarães. Em um dos pesadelos do Conde, após errar a esmo por uma floresta, encontra uma igreja, cujos sinos dobram meia-noite. Ao entrar, se depara com um banquete, servido aos "esqueletos de craneo embucados", "cabelos roidos, ressecado", e "tórax demudado/ pelo dente dos vermes". Um deles lhe serve a taça de vinho vermelho denso e sabor de sangue. Eis que, entre a "ruidosa vozeria dos fantasmas", ouve-se o chamado ao baile:

\footnotetext{
“À dança! à dança!/À dança! à dança!”- todos/Em côro repetiram - longo círculo/Dadas as frias mãos formaram todos/Em torno ao Conde Lopo - com tal força/Ante ele a voltear - que só lhe ouvia/O confuso tropear rangendo a pedra/E o frio rir e o retinir dos ossos!"
}

\footnotetext{
${ }^{194}$ Para Antonio Candido, além da influência da geração mais nova de românticos, Magalhães pode ter se inspirado em autores como o italiano, morador do Rio de Janeiro, Luís Vicente de Simioni que em 1842 publicara poemas tumulares; o português, também residente no Rio de Janeiro, Borges de Barros $(O s$ túmulos) e o espanhol Cadafalso (cujas Noites lúgubres foram traduzidas e publicadas pela revista Minerva Brasiliense), textos de tinham os mesmos "tons lutuosos" dos Cânticos Fúnebres e eram contempoâneos a eles. (CANDIDO, 2009, p. 385)

${ }^{195}$ MAGALHAENS, 1864, p. 121.
} 
Já no pequeno conto A dança dos ossos, de 1871, um caboclo conta ao narrador da vez em que, perdido no meio da mata, de madrugada, encontrou a tumba de um morador local que havia sido enterrado lá após uma morte bastante trágica. Fora, desta feita, testemunha do evento que todos na região temiam: viu acordar o esqueleto do defunto. Imitando o linguajar regional, o autor conta como, de dentro da terra, viu saltar os ossinhos brancos estalando uns nos outros, ritmadamente, desde os pequenos até os maiores, desenvolvendo uma animada coreografia. Por fim, vem a caveira, "com olhos de fogo e dando pulos como um sapo". Os ossinhos mais miúdos, sempre em movimento, se aproximam e, aos poucos, formam os pés, que não páram de sapatear. Os da canela pulam sobre eles, e depois os das pernas, quadris, costelas, braços, todos os que estavam espalhados iam encontrando seu lugar. "Pensei que nada mais teria que ver; mas ainda faltava o mais feio”, diz o narrador a essa altura. O esqueleto, quase inteiro, pega a caveira, faz com ela "mil artes e piruetas, joga peteca com ela e atira-a pelos ares". Finalmente coloca-a em seu lugar sobre as escápulas, fazendo um estrondoso e assustador ruído. Mas não acaba aí: "O maldito esqueleto do inferno Deus me perdoe! - não tendo mais nem um ossinho com quem dançar, assentou de divertir-se comigo". Assim como nas danças medievais, o caipira, assustado, admite que estava "duro como uma estátua", com "o coração que não batia", "mais morto do que vivo, sem um pingo de sangue" em contraposição ao esqueleto folgazão.

Na poesia, os defuntos que acordam e querem retornar à terra também aparecem. Em Junqueira Freire (Mais um túmulo), por exemplo, os monges esqueléticos, ainda sujos de carniça, tentam atravessar o sepulcro monástico, destruindo o campanário, após despertarem. Tudo, porém, não passa de uma miragem:

Quantas campas aquí quebram-se e correm!

Quantos crânios, - que horror! - de sânie sujos, Surgem medonhos delas!

Eis! de um lado levantam-se, frangendo, De negras togas adornados todos, Altivos esqueletos! Ah! estoutros, porém, forcejam, lutam. Tremendos uivam, por querer debalde Transpôr-se do sepulcro. ${ }^{196}$

\footnotetext{
${ }^{196}$ FREIRE, 1944, p. 221,
} 
No Simbolismo de forte tom romântico de Augusto dos Anjos, que abusa das imagens macabras, a dança dos esqueletos está presente em As cismas do sujeito:

Os esqueletos desarticulados,

Livres do acre fedor das carnes mortas,

Rodopiavam, com as brancas tíbias tortas,

Numa dança de números quebrados! ${ }^{197}$

A mesma imagem encontra-se em Venceslau de Queirós, conhecido imitador de Baudelaire, ${ }^{198}$ no poema Nevrose, publicado em 1890. Em uma "noite de agro remorso", o narrador em agonia, com os sentidos corrompidos, ouve "na treva gemidos" e na sombra vê fantasmas. Tem visões de mortos em um cortejo. Nesse pesadelo em que "Tomam corpo e forma hedionda" os seus sonhos "mais secretos", ele assiste a uma "frenética ronda", constituída por "uma porção de esqueletos". 199

Pode-se concluir, portanto, que a dança macabra era tema conhecido entre os poetas brasileiros do século XIX, tamanha a quantidade de referências a elas. E não só em peças literárias. Lady Mary Graham, escritora inglesa que esteve no Brasil algumas vezes na década de 1820 , conta em seu diário ${ }^{200}$ que, em uma de suas visitas, em 1822 , conhecera um certo conde Dirk von Hogendorp. Ex - general holandês que servira nas tropas napoleônicas, o conde emigrara para o Brasil e vivia no Rio de Janeiro desde 1816. Convidada a visitar sua residência, uma pequena fazenda nos arredores do Corcovado, Miss Graham relata o que viu em seus aposentos pessoais: paredes pintadas de preto com desenhos de animados esqueletos, em uma composição que parecia ser... uma dança macabra: "his bedroom, the walls of wich, with a capricious taste, are painted in black, and on that sombre ground, skeletons of the natural size, in every attitude of glee, remind one of Holbein's Dance of Death. "201

Histórias como a do conde e a gravura do Cabrião ${ }^{202}$ confirmam essas suspeitas. No entanto, apesar da referência direta às danças macabras, em todos os textos literários

\footnotetext{
197 ANJOS, 1996, 24.

${ }^{198}$ CANDIDO, 1989, p. 22.

${ }^{199}$ In: RAMOS, 1965, p. 58.

${ }^{200}$ Publicado em Londres, em 1824, com o título de Journal of a voyage to Brazil and residence there, during part of the years 1821, 1822, 1823.

${ }^{201}$ GRAHAM, 1824, p. 171-2.

${ }^{202}$ Comentada na Introdução deste trabalho.
} 
citados, é possível observar aspectos que escapam às obras originais da Idade Média. Em Bernardo Guimarães, o esqueleto ressurge à terra com o propósito de assustar os vivos com sua dança; em Álvares de Azevedo, os mortos realizam um verdadeiro festim, que acaba em bebedeira e orgia. Nenhuma das soluções é partícipe das premissas dos exemplares medievais. Claramente, algo mudou. Porque continuaram a ser produzidas no século XIX, as danças macabras revelam a continuidade daquele imaginário - mas suas modificações denotam também sua instrumentalização, obedecendo a demandas outras, próprias de outro tempo e de um outro olhar sobre a morte. 


\section{As danças macabras no século XIX}

La danse macabre s'appelle Que chacun à danser apprend A l'homme et femme est naturelle: Mort n'épargne ni petit ne grand. La Danse Macabre de Guyot Marchand, 1485.

Les charmes de l' horreur n' enivrent que les forts! Baudelaire, Danse Macabre, 1861.

A Dança Macabra foi um motivo imagético e poético bastante popular a partir do século $\mathrm{XV}$, sendo a principal responsável pela difusão dos temas macabros no período - isto é, das produções culturais que colocavam em evidência o corpo humano em putrefação post mortem. Não obstante seu grande sucesso até o século XVI, as Danças tiveram, paulatinamente, seus elementos ressignificados, o que acabou por esfacelar o cunho dramático e instrutivo, mas também satírico, das primeiras obras - a ponto de André Corvisier afirmar que "durante o Renascimento, as danças sofreram uma "perda de alma". 203

Diversos fatores caracterizam essa perda. Um deles, seguramente, é o abandono da imagem perturbadora do transi, substituído definitivamente pelo esqueleto.

${ }^{203}$ CORVISIER, 1998, p. 59. 


\section{A “dança de Holbein" e o esqueleto}

É em forma esquelética que os mortos aparecem na obra Simulachres \& histoires facées de la Mort, de Hans Holbein, o jovem. Composta entre 1523 e 1526 e publicada pela primeira vez em Lyon, pelos editores Melchior e Gaspar Trechesel, em $1538,{ }^{204}$ a série de xilogravuras compõe uma dança macabra modernizada. Seu êxito comercial e alcance foram tão grandes que fizeram a fama do gênero muito mais do que os originais medievais: "Cette édition, et les suivantes, ont conquis l'Europe. Une multitude de réalisations vont s'inspirer, jusqu'en le XXe siècle”, comenta Bertrand Utzinger. ${ }^{205}$ Suas inegáveis qualidades estéticas são superiores às danças do século XV, sendo as imagens mais ricas em detalhes e em cenário, ${ }^{206}$ mas a diferença primordial com sua ascendência é estrutural: Holbein nos introduz aos vivos no contexto em que vivem, não sendo chamados em fila, mas realizando suas atividades cotidianas. São cenas com os mesmos personagens das danças tradicionais, no entanto, não se trata mais de um tipo de alegoria que junta vivos e cadáveres dançarinos, em uma improvável ciranda. Trata-se de figurar a real imprevisibilidade da morte, já que os vivos são surpreendidos nos afazeres de sua rotina, por um morto disfarçado e misturado à cena (figuras 1, 2, 3 e 4):

Le laboureur laboure, la hotte du marchand ambulant déborde de mercerie, les autres marchands sont entourés de ballorts, l'enfant refuse de suivre un inconnu. Avec Holbein la suite compassée de chaque vivant s'anime en une scène plantée dans le décor qui leur est familier. Holbein a fait de la danse macabre un thème décoratif. ${ }^{207}$

A afirmação de Corvisier é ainda mais contundente se considerarmos o Alphabet de la Mort, também de Holbein, publicado pela primeira vez na Basiléia, em 1531, e com diversas reimpressões, inclusive em outros locais e línguas. Cada gravura contempla uma letra maiúscula do alfabeto e sua configuração é a mesma das danças

\footnotetext{
${ }^{204}$ Seus versos são atribuídos a Gilles Corrozet e as gravuras em madeira feitas por Hans Lutzelburger, a partir dos originais de Holbein.

${ }^{205}$ UTZINGER, 1996, p. 162.

${ }^{206}$ No entanto, em relação ao texto que acompanha as imagens, é curioso notar que não se tratam dos versos típicos das danças macabras. Cada gravura é acompanhada de uma frase edificante das Escrituras en latim (sobre a cena) e de 4 versos (abaixo), em francês - no original, ou nas diversas traduções que a obra de Holbein conheceu -, sobre a vítima mostrada.

${ }^{207}$ CORVISIER, 1998, p. 64.
} 
macabras, mesmo sem receber esse nome. Em "A", vê-se dois cadáveres-músicos; de "B" a "Y", os personagens, do papa ao bebê, junto de seus mortos e, enfim, em "Z", o Julgamento Final. Ou seja, com mais força a partir de Holbein, o encontro entre vivos e mortos se desvincula da estrutura típica das danças - e também dos poemas assim denominados.

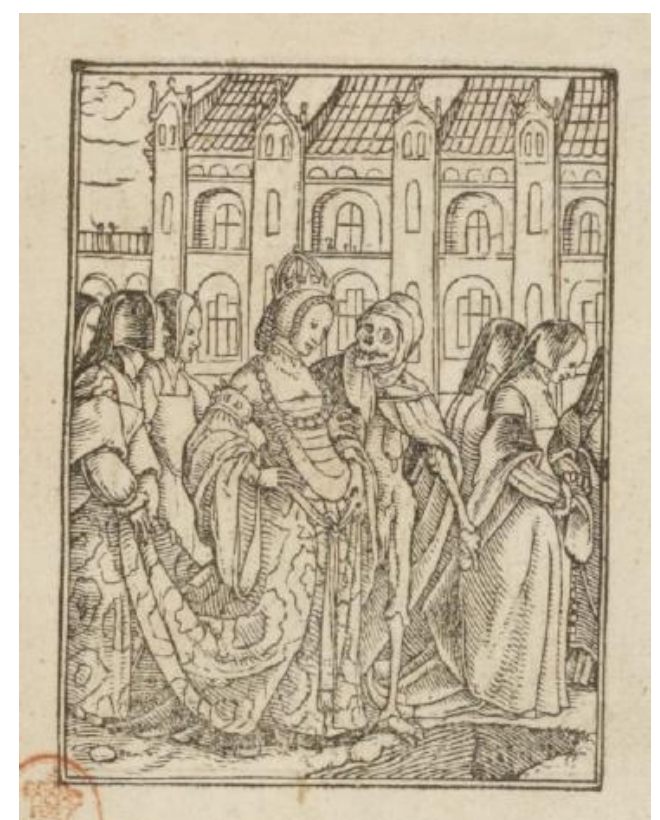

Figura 1: a Morte e a Rainha

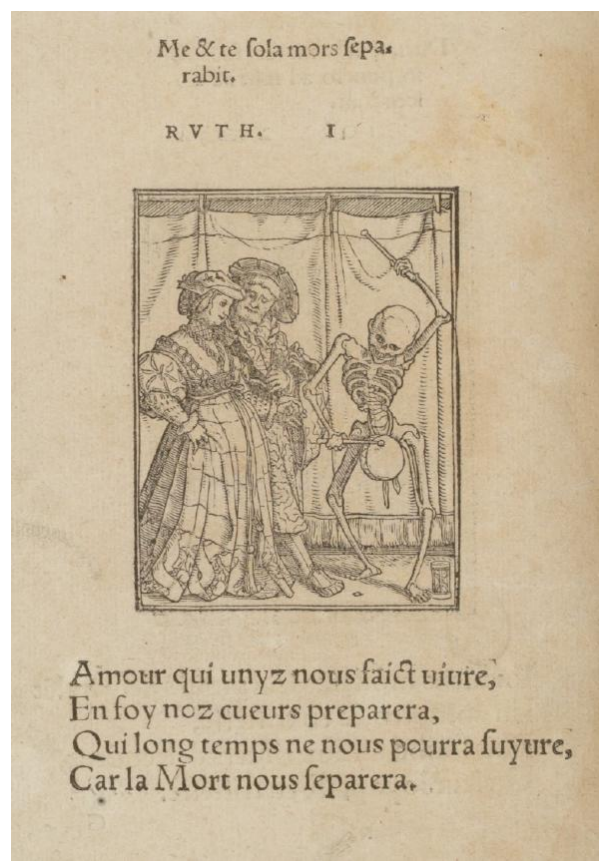

Figura 3: uma página inteira do Simulachres. A Morte e os recém-casados.

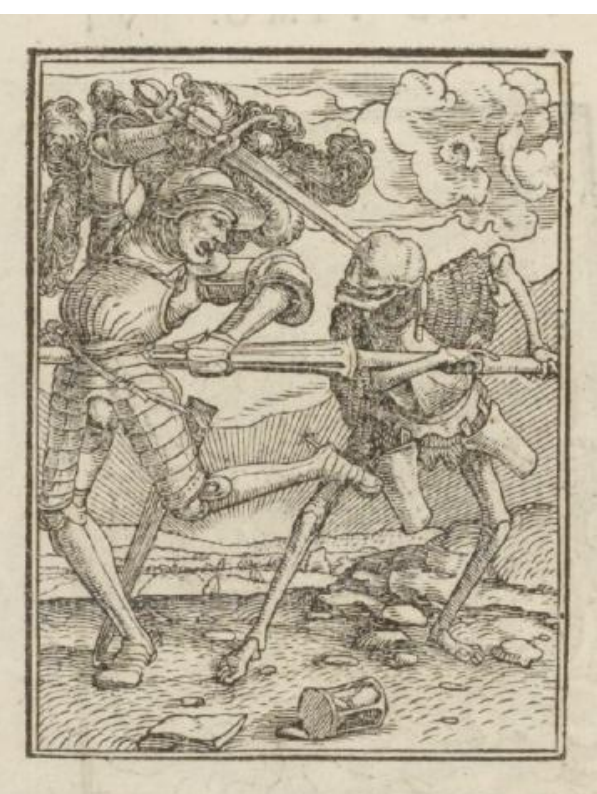

Figura 2: a Morte e o cavaleiro.

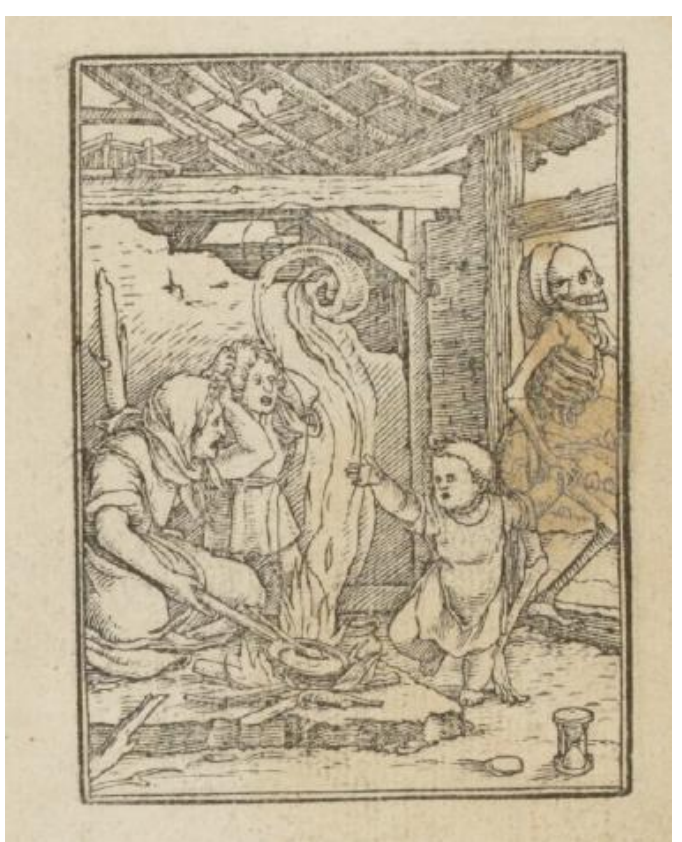

Figura 4: a Morte e a criança. 
O que chama a atenção é que, em ambas as obras, os cadáveres de Holbein são esqueletos. Essa representação da ossada evidencia a tendência em substituir o transi, mesmo nesse que foi o gênero anteriormente responsável por expô-lo com mais veêmencia. Assim, de maneira geral, as representações da "morte úmida”, da carniça (viscosa, com seus licores fétidos, miasmas e vermes vis, por isso, mais amedrontadora), dão lugar à "morte seca", aos ossos. Mas o sinal da mudança em relação à morte na era moderna não foi exclusividade das produções iconográficas. De acordo com Michel Vovelle, uma reação à imagem da decomposição já se percebia, por exemplo, nos rituais de exéquias do período barroco, em especial na morte dos grandes da sociedade, nas quais o cadáver passava a ser escondido e sua presença simbolizada por efígies vestidas com os trajes usados em vida. Provavelmente um dos último exemplares da estatuária macabra medieval, a efíge no túmulo de Jeanne de Bourbon, condessa do Auvergne, de 1523, era, então, uma admirável exceção. Mesmo na poesia: à parte obras de poetas como Pierre de Ronsard (1524-1585) ou Joachim du Bellay (1525-1560), o macabro aos moldes medievais saía progressivamente de cena.

Philippe Ariès também associa esse desaparecimento generalizado da carniça na arte e na literatura ao seu sumiço gradual nos testamentos dos séculos modernos, sugerindo que o desinteresse era mais profundo, indicando um declínio pungente da preocupação com os próprios despojos mortais. "Le goût macabre s'efface”, decreta Michel Vovelle. ${ }^{208}$ Mesmo as impressionantes catacumbas italianas (as dos capuchinos de Roma e de Palermo são as reminiscentes), ostensivamente decoradas com ossos e esqueletos completos, alguns vestidos com o hábito dos frades, apesar do choque que provavelmente geram até hoje, pertencem a esse momento no qual o repulsivo macabro medieval do apodrecimento deu lugar à um macabro ascetizado, controlado, limpo. A devoção às relíquias de santos, geralmente pedaços de ossos, dentes ou cabelos, obedeceriam a esse mesmo princípio ${ }^{209}$ : “. Nous ne voyons plus de peintures réalistes et d'inspiration macabre; le theme de la mort s'est modifié."210

Desinteresse da arte; interesse da ciência: ao mesmo tempo que o esqueleto dominava a personificação da morte, o cadáver (agora limpo dos vermes que o corroem e dos fedores que o impesteam) passava a ser objeto de estudo, da medicina, das

\footnotetext{
${ }^{208}$ VOVELLE, 1983, p. 222.

${ }^{209}$ VOVELLE, 1983, p. 245-6.

${ }^{210}$ LARMAND, 1910, p. VI.
} 
dissecações até então proibidas pela Igreja, devassado por outros tipos de produção cultural. Desenhistas e gravuristas se associam aos anatomistas e o fascínio pela morte se cobre de um verniz científico.Tratados de medicina legal publicados no século XVII examinam o comportamento cadavérico em busca de soluções para questões criminais ou de saúde pública, com a crença de que o cadáver contém os segredos da vida e da morte. A capa do De humani corporis fabrica, de Andreas Vesalius, primeiro tratado de anatomia da era moderna, publicado em 1543, reproduz a cena de uma dissecação em um anfiteatro. Uma multidão se espreme para assistir o procedimento. Nas páginas seguintes, uma série de corpos - sem pele, sem músculos e, finalmente, esqueletos, sempre meditativos e serenos, nunca repulsivos - revelam os segredos da máquina humana. A aula de anatomia do Dr Tulp, de Rembrandt, de 1632, e as ecorchés de Honoré Fragonard, feitas e expostas na década de 1760, revelam a manutenção do tema da morte cientifizada e a atração que ela suscitava naqueles séculos.

Essa mudança do macabro, tanto de forma (o esqueleto - ou sua versões resumidas: o crânio e o crânio com as tíbias cruzadas) quanto de sentido (deslocado da ênfase da podridão como destino aterrorizante do corpo) inicia, de acordo com Ariès, a "segunda era do macabro": "a finalidade do tema macabro já não é revelar a obra subterrânea da corrupção. O horrível trespassado, roído pelos vermes, dilacerado pelas cobras e os sapos, foi substituido pelo belo esqueleto limpo e luzente, a "morte seca" com que as crianças ainda brincam hoje na Itália, e no México em qualquer tempo. Não causa tanto medo, não é tão mal.",211 $\mathrm{O}$ esqueleto foi, na era moderna, o memento mori por excelência, onipresente nas reflexões sobre a vida, elemento fundamental na composição das Vaidades e das naturezas-mortas, sendo utilizado, muitas vezes, como imagem alegórica do Tempo. Sua presença, assim, se banaliza na iconografia ocidental. É ele, o esqueleto, segurando a foice e montado à cavalo, que identifica a Morte nas representações dos cavaleiros do Apocalipse, a partir de então. ${ }^{212}$

O século XVII e praticamente a totalidade do XVIII foram, portanto, quase indiferentes às Danças Macabras (assim como às outras manifestações medievais do macabro, como a Lenda dos três vivos e dos três mortos, os Ars Moriendi e os Triunfos

\footnotetext{
211 ARIÈS, 1989.

212 VOVELLE, 1983, p. 207.
} 
da Morte $^{213}$ ), apesar delas nunca terem deixado de ser reimpressas, especialmente as versões de Marchand e de Holbein (essa última, cerca de 88 vezes, até o fím dos setecentos, em francês, latim, italiano, alemão, castelhano, inglês ${ }^{214}$ ). A representação dos diferentes estratos sociais da medievalidade vai perdendo importância, uma vez que as Danças evocavam uma sociedade que, aos poucos, deixa de ter similitudes com aquela. No caso da França, em particular, talvez onde o gênero mais repercutiu e foi reproduzido, é emblemático que não haja indícios de novas obras até o fim do século XVIII: "le seul effort consiste à rajeunir l'ortographe. La qualité de ces publications baisse et leur prix également", comenta Corvisier. Os editores se esforçavam no sentido de atualizarem os vocábulos e o vestuário dos personagens, no entanto, as Danças viram diminuir seu poder moralizante perante uma gente que já não se reconhecia mais nas figuras que elas evocavam.

Além do mais,

cette dure leçon du rejet des biens terrestres s'estompe progressivement à partir du XVIIe siècle: non que les Danses macabres disparaissent à cette époque, mais celles qui sont crées vont perdre quelque peu ce caractère d'authenticité médiévale: le style va changer, la forme se modifier légèrement; la Danse macabre du siècle des Lumières ne sera qu'une copie dont l'impact sociologique se sera sensiblement attenué. ${ }^{215}$

Muitos dos afrescos foram danificados, denotando o descaso com essas obras consideradas de pouco valor artístico - como foi o caso do afresco da abadia de La Chaise-Dieu, irremediavelmente estragado após a construção de uma escada sobre o segundo painel, na década de 1840. Alguns foram destruídos por supostamente simbolizarem o pensamento rudimentar e a barbárie de tempos supersticiosos (a dança de Lydgate em Londres, por exemplo, em 1559, sob o reinado do monarca protestante Eduardo VI); outros tantos foram cobertos por massa e escondidos por gerações (como em Meslay-le-Grenet, descoberta acidentalmente apenas em 1864) - e até hoje causa espanto quando algum deles é revelado ('Danses macabres de toute l' Europe, combien

\footnotetext{
${ }^{213}$ Segundo Michel Vovelle, ambos já teriam entrado em declínio a partir de meados do século XV. (1983, p. 142)

${ }^{214}$ INFANTES, 1997, p. 178.

${ }^{215}$ UTZINGER, 1996, p. 14.
} 
d'entre vous dorment encore sous le badigeon, attendant une deuxième naissance?" perguntavam Helène e Betrand Utzinger, em $1996 .{ }^{216}$ ).

\section{Retomada e atualização do tema}

É bastante provável que os poetas dos oitocentos tivessem contato com as gravuras de Guyot Marchand, Antoine Vérard e, principalmente, com as de Hans Holbein, em suas diversas versões e reimpressões: "En effet c'est par la gravure que survivent le plus souvent les danses macabres. "217 Sabe-se que entre 1747 e 1818, os Simulachres foram reeditados pelo menos uma dezena de vezes em Londres ${ }^{218}$ e que serviram de modelo para novas obras no final do século XVIII, como a dança do gravurista suiço Johann Rudolf Schellenberg (1785) e a do alemão Daniel Nikolaus Chodowiecki (1791). Em ambas, as cenas de gênero, retiradas do cotidiano das vítimas de uma Morte em forma esquelética, disfarçada e misturada ao entourage, sofrem uma formidável revisão indumentária, mas mantêm o modelo holbeniano.

O mesmo ocorre em The English Dance of Death, do artista e caricaturista Thomas Rowlandson, de 1814, série de gravuras coloridas muito irônicas, até engraçadas em algumas cenas - como na que a Morte luta aos socos com um sujeito; leva embora um homem gordo num carrinho de mão; mostra ameaçadoramente uma ampulheta para foliões bêbados que pulam o Carnaval. Ou quando mistura sorrateiramente veneno nos barris de vinho servidos numa animada taberna. A mais graciosa é a do frontispício: a Morte, com todos seus intrumentos e armas infalíveis, soberana de coroa de ouro, sentada em seu trono que é o próprio globo terrestre e... entediadíssima! (figura 5)

\footnotetext{
${ }^{216}$ UTZINGER, 1996, p. 13.

${ }^{217}$ CORVISIER, 1998 p. 96.

${ }^{218}$ Idem, ibidem.
} 


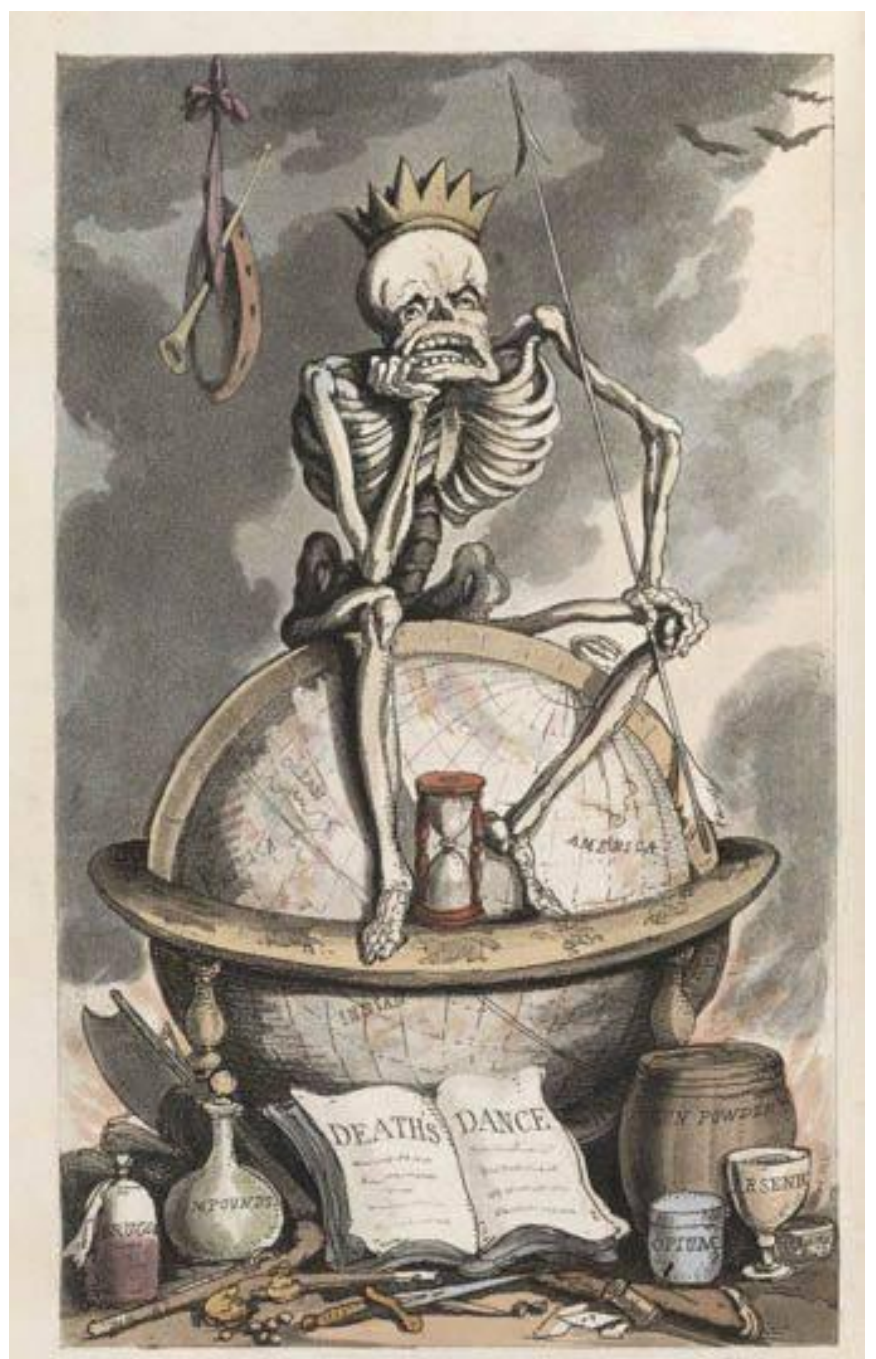

Figura 5

Embora o padrão holbeiniano seguisse inabalável, houve algumas notáveis exceções. The Dance of Death Modernised, de G. M. Woodward, é uma deliciosa sátira da sociedade inglesa, publicada em Londres, em 1808. O formato dos afrescos medievais é recuperado - duplas de personagens vivo-morto, os primeiros sendo puxados pelos segundos, que dançam alegremente (figura 6). O texto foi reduzido ao mínimo, limitando-se a frases emitidas pelos vivos, que complementam o humor da cena. O rei, por exemplo, primeiro personagem, é atraído pelo esqueleto à sua frente que o seduz segurando sua coroa, a quem diz: "Return the Diadem and I'll follow you". A mesma negociação parece querer um burguês, que, vendo seu saco de moedas entre as falanges do esqueleto que o conduz, lhe promete: "Spare my money and I'll go contented". Uma senhora do povo, aparentando certa idade (lhe faltam dentes na boca e usa óculos), implora para ficar um pouco mais: "Let me stay till I a married and I'll ask 
no longer time", enquanto a jovem bem vestida carregando acessórios diversos reclama ao esqueleto que lhe puxa "Don't be so boisterous you filthy wretch, I am a woman of fashion", e assim por diante.

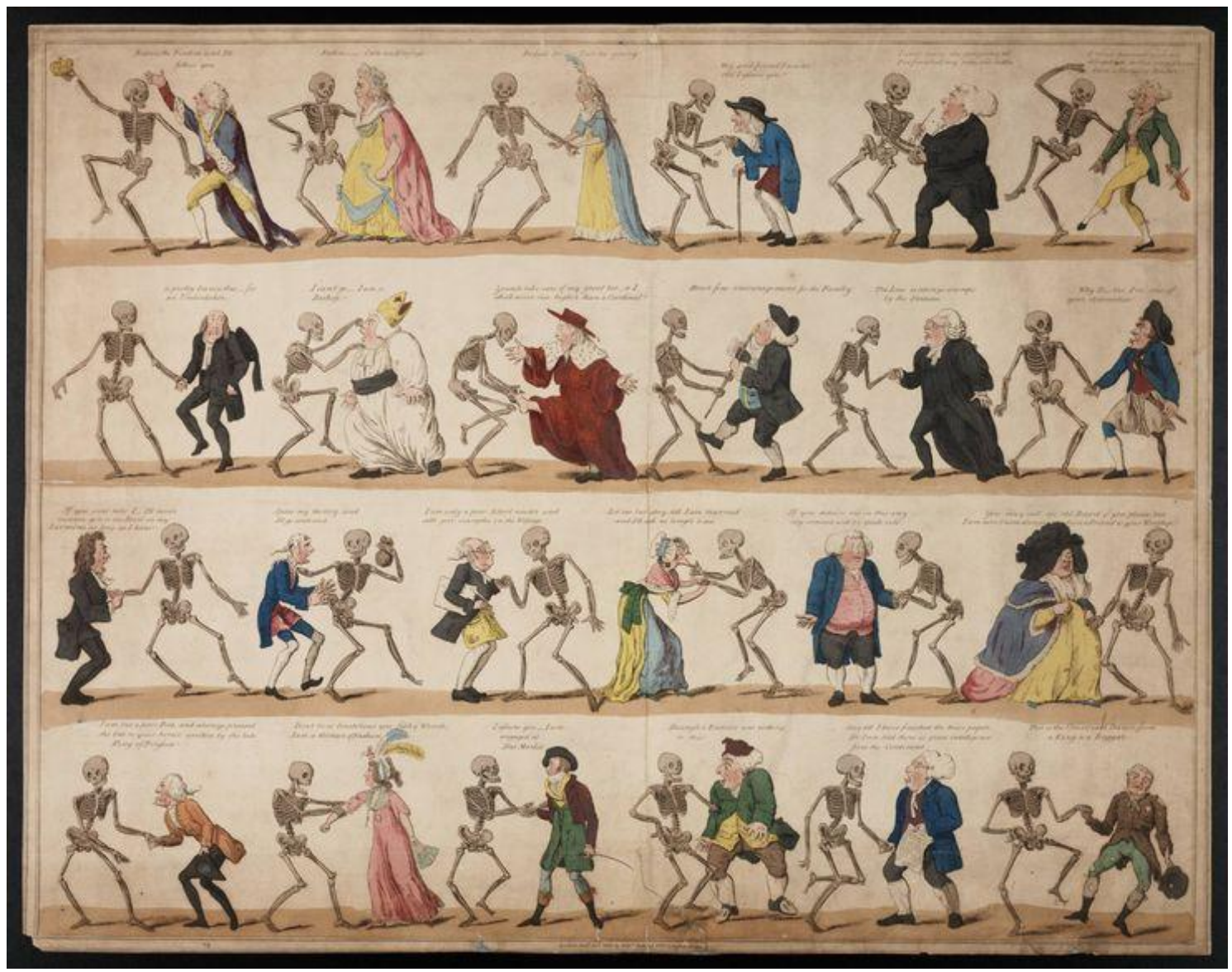

Figura 6

A Todtentanz do pintor prussiano Alfred Rethel, feita em meio aos levantes de 1848, supreende ao converter a mensagem cristã da preparação ao trespasse em crítica política. Em sua dança, os mortos-esqueletos incitam o povo a insurgir-se - o tom é conservador, diga-se de passagem: Rethel é um contrarrevolucionário, a obra pretende instruir sobre o equívoco fatal de se tornar um rebelde, que é o equivalente a seguir a morte (figura 7). "The series was received immediately as a major political statement, and reproduced as illustrations for the conservative viewpoint everywhere in Germany and in France.(...) Rethel presents Death ironically as the consummate political 
seducer, in this case as the radical who exploits republican rhetoric to enlist the working classes on behalf of a hidden agenda. "219

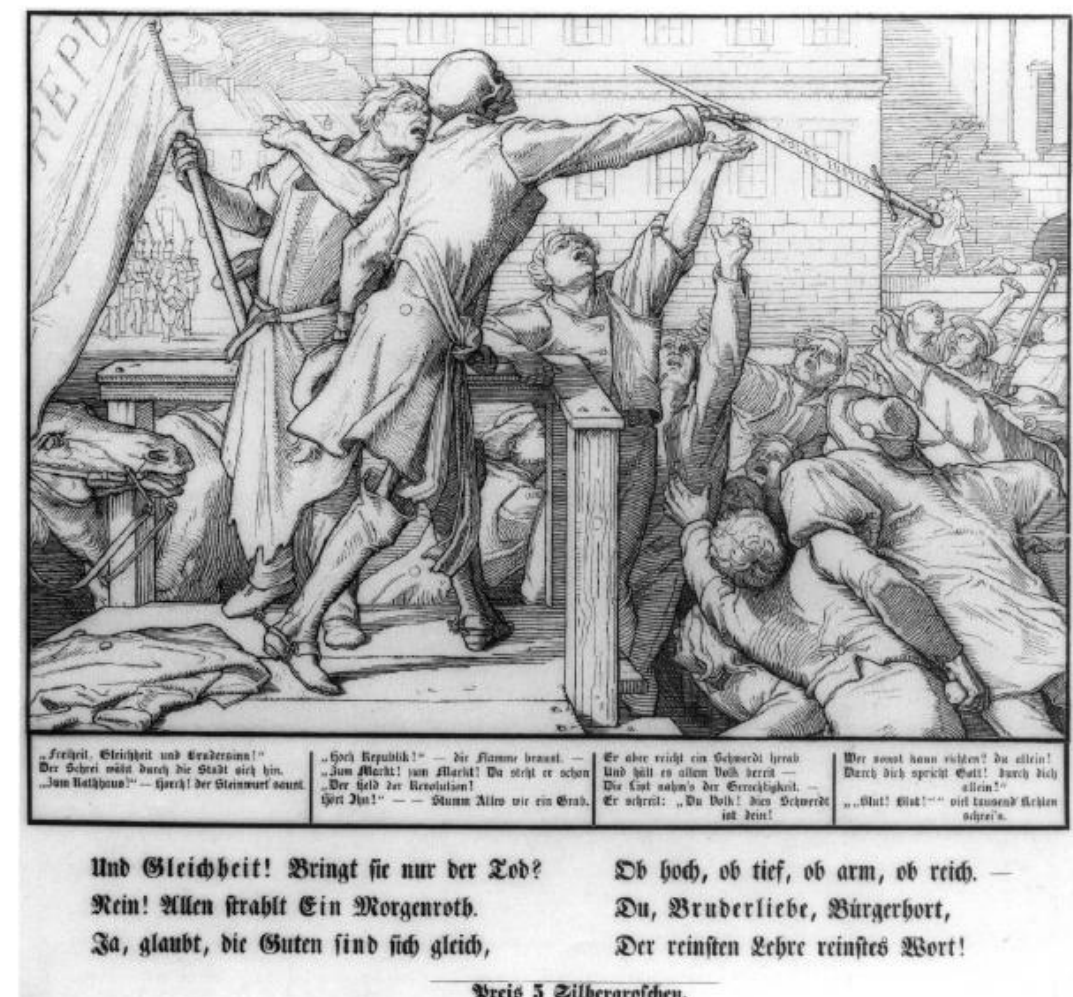

Figura 7: quarta prancha da série de Rethel

\section{O interesse dos historiadores}

Além das imagens impressas e das pinturas em tela para Igrejas (em quantidade pouco expressiva e que substituiam a produção de afrescos ${ }^{220}$ ), também contribuiu para

\footnotetext{
${ }^{219}$ BOIME, 1991, p. 549-584. O autor continua: By mid-June [um mês após o lançamento da primeira edição] a third edition appeared; within a year nearly fifteen thousand copies were sold; the Conservative Alliance of Saxony brought out a special printing, and there were numerous pirated editions. E mais à frente: The conservative french journal "L'Illustration" published the entire series on 28 july 1849 (...) The publishing house of Goupil presented the album the following year, cleverly inserting the term "Le Socialisme" in its title ("Le Socialisme. Nouvelle danse des morts") (...). (p. 583) Além das séries mencionadas, sabe-se também da existência da Die arbeit des Todes: ein Todtentanz, xilogravuras de 1866, de Ferdinand Barth, que "met en scène des morts accidentelles: chute, enlisement, guerre, tempête, suicide, exécution capitale", na qual "les morts sont particulièrement ironiques."(CORVISIER, 1998, p. 98.). Como não foi possível obter maiores informações sobre essa obra, ela não foi incluída no texto.

${ }^{220}$ Uma lista com essas obras aparece em Corvisier (1998, p. 97).
} 
o reflorescimento da temática das danças macabras o interesse da historiografia pelo gênero, aproveitando o fluxo da onda medievalista do início do século. Entre essas obras, a pioneira é de 1811, de Champollion-Figeac, Notice d'une édition de la danse macabre, anterièure à celle de 1486, et inconnue aux Bibliographes. (publicado em Paris, sobre a primeira edição da dança de Holbein, de 1485). Destacam-se na sequência a essa, Recherches Historiques et Littéraires sur les Danses des Morts, de Gabriel Peignot, publicado em Paris, em 1826; La Danse Macabre, histoire fantastique du XVe siècle, de Paul Lacroix (Paris, 1832); The Dance of Death, de Francis Douce, publicado em Londres em 1833; Literatur der Totentanze, de H.F. Massmann (Leipzig, 1840), Essai historique, philosophique et pittoresque sur les danses des morts, de E. H. Langlois, publicado em Ruen, em 1851 (considerado referência fundamental para os estudos do tema ainda hoje, pelo levantamento bastante completo que o autor realizou das obras produzidas até então); Les danses des morts, dissertations et recherches historiques, littéraires et musicales, de Georges Kastner (Paris, 1852); além de títulos específicos como La Danse des Morts de la Chaise-Dieu, por Achille Jubinal (Paris, 1841); La danse des morts dessinée par Hans Holbein. Essai sur les poèmes et sur les images de la danse des morts de Hippolyte Fortoul (Paris, 1842) e L'alphabet de la mort de Hans Holbein, de 1866, uma análise feita por A. de Montaiglon.

De seus estudos sobre as danças macabras, Paul Lacroix e Georges Kastner encontraram matéria para desenvolverem as suas próprias peças, cada qual com sua particularidade. O primeiro descreve uma fictícia ação teatral no antigo cemitério de Saints-Innocents, cujo desenrolar teria servido de fonte para o autor anônimo do afresco lá pintado. Kastner, interessado especialmente no elemento rítmico das danças, cria uma música nelas inspirado.

A despeito de ter escrito sobre a Idade Média e o Renascimento em uma obra monumental em 5 volumes (Le Moyen âge et la Renaissance, publicados entre $1847 \mathrm{e}$ 1851), em tom acadêmico e erudito, em La Danse Macabre, histoire fantastique de XVe siècle, de 1832, Paul Lacroix permitiu-se vôos imaginativos longínquos (que, não obstante, marcaram profundamente a retomada do gênero - o livro teve 2 reedições no mesmo ano do lançamento, outra em 1838 e mais uma em $1851^{221}$ ). Entrelaçada à uma trama que misturava enredo de romance gótico (com direito ao casal apaixonado cujo

${ }^{221}$ INFANTES, 1998, p. 35 - nota 97. 
amor é impossível, judeus ganaciosos e verdades do passado sendo reveladas) com informações históricas, o autor nos coloca diante dos acontecimentos culminariam na confecção da dança macabra de Saints-Innocents.

Somos, então, conduzidos à Paris no ano de 1424, quando chega à cidade uma figura misteriosa, "Macabre", que ocupa a torre de Notre Dame de Bois, pequena e antiga construção localizada dentro dos muros que cercam o cemitério dos Inocentes, cuja função nunca foi desvendada exatamente. Esse "étrange locataire", ${ }^{222}$ teria chegado à cidade junto com a ocupação inglesa e logo ganhou fama de recluso. Macabre era uma figura sui generis. Vestia-se sempre com uma túnica longa de lã negra feita de um traje mortuário roubado de um defunto ("à le voir sans mouvement, on eût douté s'il était mort"). Sua magreza extrema permitia que se visse os osso por baixo da pele - tão colada ao esqueleto que as veias, os nervos e os músculo não passavam de finas saliências; os lábios quase inexistentes deixavam os dentes descobertos; tinha os olhos fundos e a cabeça lisa, limpa de cabelos. Seus movimentos eram acompanhados do barulho dos estalos de sua carcaça; os membros se chocando a cada passo. A voz fleumática e "l'odeur cadavérouse" que exavala completavam sua figura melancólica e amedrontadora. Na cidade, acreditavam que ele tinha o poder de acordar com os mortos com o som de sua rabeca ("Aucuns disaient que le rebec de Macabre révaillait les morts au clair de lune,"223); os boatos a seu respeito eram tantos que o cemitério, graças a ele, passava por lugar maldito ("on évitait de traverser de cimetière, même en plein jour, et personne n'osait s'aventurer dans les rues environnantes après le coucher $d u$ soleil". ${ }^{224}$ ).

Duas únicas ocasiões levaram Macabre em meio ao povo parisiense:

[ele] ne se montrait en public qu'à l'occasion d'un spetacle effrayant dont il était l'inventeur, et les Parisiens avaient vu jouer durant plusiers mois en 1424 et en 1429. Ce spetacle, que des auteurs du quinzième siècle ont cherché à reproduire en rimes sous le titre de "danse macabrée" ou "macabre", nom que l'inventeur avait pris; ce spetacle fantastique n'était qu'une interminable procession d'hommes et de femmes choisis dans tous les âges et tous les rangs, que la mort faisait entrer en danse, selon l'expression proverbiale, qui signifiait sortir de la vie.

\footnotetext{
${ }^{222}$ LACROIX, 1832, p. 23

${ }^{223}$ LACROIX, 1832, p. 26.

${ }^{224}$ LACROIX, 1832, p. 26.
} 
Macabre teria sido, então, o criador de tal espetáculo teatral cujo texto ele teria trazido da região da Boêmia, de onde era oriundo. Após apresentá-lo por duas vezes, (das quais a primeira teria resultado no afresco pintado em uma das galerias), ele se prepara para nova exibição, em 1434, ano em que se passa o relato de Lacroix - ano de fome e de peste e Paris. O acontecimento mobiliza a cidade e desde cedo, os habitantes ocupam o cemitério: "Dès le point du jour, qui se levait clair et resplendissant, la foule se pressait autour du cimetière des Saints-Innocents. "225 Mais de cinquenta mil pessoas estavam lá e se espremiam em volta dos muros do quadrilátero, invadiam as torres, subiam nos monumentos. A dramatização começa uma música "suave e terrível", que “imitait les rires et les saglots, les chant des anges et le cris des damnés. "226 Um ator entra em cena, declamando a estrofe que abre a dança macabra de Guyot Marchand, de 1485 (mas que, na história, seria de autoria de Macabre):

La danse macabre s'appelle Que chacun à danser apprend A l'homme et femme est naturelle: Mort n'épargne ni petit ne grand.

Uma voz "grave e formidável", em seguida, chama três vezes pelo Papa. Ao mesmo tempo, Macabre, com sua rabeca em mãos, surge diante do público. Sua presença fantasmagórica causa impacto na platéia: "cette aparition fut suivie d'une rumeur de surprise et d'effroi ": 227

Il était entièrement nu, sauf un linceul assujettti autour des reins par une décence inutile, et flottant sur ses épaules, un lambeau de cuir ensanglanté pendait pour imiter la place du ventre ouvert et les entrailles à jour, selon l'usage convenu de caractériser la Mort. Cette fantastique nudité mettait en relief les formes aiguës du squelette, le parchemin terreux qui l'enveloppait, et l'alliance bizarre de la mort avec la vie. ${ }^{228}$

\footnotetext{
${ }^{225}$ Idem, ibidem, p. 166.

${ }^{226}$ Idem, ibidem, p. 181.

${ }^{227}$ Idem, ibidem, p. 182.

${ }^{228}$ Idem, ibidem, p. 183.
} 
Macabre era a própria personalização da Morte, que era seu papel na peça, e sua caracterização correspondia à imagem do transi - e tão verossímel que "on le soupçonna d'avoir quitter sa bière pour jouer son rôle."

O espetáculo continua com um ator travestido de Papa, de tiara na cabeça e segurando as chaves de São Pedro, implorando para não ser levado, oferencendo jóias e ameaçando excomungar a figura esquelética que caçoa de seu poder. O povo ria e aplaudia vivazmente a pantomima. O mesmo se seguiu, com a entrada do Emperador e do Cardeal. Macabre tocava o instrumento com entusiasmo, seu corpo se contorcia no rito dos acordes entoados, o que excitava o público cada vez mais.

O que a multidão não percebera é que, enquanto a peça se passava, um eclipse solar acontecia e, à essa altura da ação, ele se tornara total. A massa se desespera com a noite precoce e, em um canto do cemitério, uma tragédia ocorre: as vigas e as tábuas colocadas sobre uma das fossas comunais para receber o público cedem. Um abiso se abre, engolindo e misturando vivos e mortos. A confusão é generalizada e um mar de gente corre desesperada para todas as direções. A encenação dá lugar à uma catástrofe: "six cents personnes avaient été tuées ou blessées à cette fatale fête, et la danse des morts était devenue une effroyable réalité. "229

Não obstante seus elementos farsescos, a história contada por Lacroix é reveladora da crença na existência das danças macabras como práticas coreográficas ou teatrais.

O mal-entendido se deu devido à leitura de certos relatos da época, como o Journal d'un Bourgeois de Paris, 1405-1449, documento muito utilizado na reconstituição da vida medieval na capital francesa ocupada pelos ingleses. $\mathrm{O}$ manuscrito original acredita-se perdido, mas foi copiado algumas vezes e, dessas cópias, a mais antiga encontra-se na Biblioteca do Vaticano (vat. Reg. Lat. 1923). Outras poucas cópias, com maior ou menor semelhança ao original, estão espalhadas nas Bibliotecas de Arsenal, de Oxford, de Paris, e datam do decorrer dos séculos XVI e XVII. Um desses exemplares da Bibliothèque Nationale de France serviu de base para edições impressas; a primeira, com o texto completo, é de 1729, publicada com o título Mémoires pour servir à l'histoire de France et de Bourgogne. ${ }^{230}$ A partir daí, as

\footnotetext{
${ }^{229}$ Idem, ibidem, p. 210.

${ }^{230}$ Journal d'un bourgeois de Paris..... Introdução à edição de 1881 .
} 
diversas versões começaram a ser confrontadas e novas edições, mais completas, não pararam mais de ser publicadas.

Em sua crônica do cotidiano parisiense, em linguagem informal (quase o registro de um relato oral) e um tanto jornalística, por incluir notícias importantes e amenidades da cidade e do reino em geral, o autor anônimo, o bourgeois, fala das instisfações da gente simples, das festividades, dos acontecimentos políticos. Não poderia faltar, portanto, um comentário sobre a grande obra que tomava lugar no cemitério principal da região: “l'an mil CCC XXIIII fut faicte la Danse Macabre aux Innocents, et fut commencée environ le moys d'aoust et achevée ou karesme ensuivant". 231

Quando o tema das danças macabras volta à moda no século XIX, são muitos os curiosos e estudiosos que interpretam as palavras do bourgeois como o testemunho de uma dança feita no cemitério - como não há especificações de que tipo de obra se tratava, tomou-se o sentido literal da palavra "dança". Sob essa ótica, segundo o documento, havia acontecido uma "dança no cemitério", uma "dança macabra", cuja encenação teria durado meses (Lacroix usa os mesmos dados do bourgeois para descrever o espetáculo de sua ficção, que teria durado "du mois d'août au carême suivant,"232).

Outros textos contribuem para a confusão. Thomas Warton, um dos Graveyards Poets, publica, entre 1778 e 1781, os três volumes de sua History of English Poetry From the eleventh to the seventeenth century. Um dos poetas contemplados em sua antologia foi justamente John Lydgate, o monge beneditino responsável pela primeira tradução do poema da dança de Saints-Innocents para o inglês, em 1430. Sabe-se que Lydgate morou em Paris em 1426, quando a França estava sob domínio inglês, com a regência do Duque de Bedford. Sua visita era oficial, por ordem do Conde de Warwick, tutor do jovem Henry VI à época. Nessa ocasião, ele conheceu e reviu várias vezes o recém-terminado afresco no cemitério. ${ }^{233} \mathrm{Em}$ sua introdução à tradução da dança parisiense, o poeta declara tê-la visto "on a walle", e que foi persuadido pelos clérigos locais a traduzir os versos da "Macabrees daunce" do francês, do "frenshhe":

\footnotetext{
${ }^{231}$ Ibidem, 1881, p. 203.

${ }^{232}$ LACROIX, p. 24.

${ }^{233}$ OOSTERWIJK, 2009, p.
} 
Considereth this / ye folkes that ben wyse

And hit emprenteth / in yowre memorialle

Like the exawmple / whiche that at Parise

I fownde depicte / ones on a walle

Full notabely / as I reherce shal

The of frensshe clerkes / takyng acqueyntaunce

I toke on me / to translaten al

Owte of the frensshe / Macabrees daunce

Em seguida, o monge admite ter obedecido ao pedido dos colegas franceses ("I obeyed / vnto the requeste // The of to mark / a pleyne translacioun // In Inglisshe tunge / of entencioun"), mas assume que não traduziu literalmente, "not worde be worde / but folwyng the substaunce."234

Warton, ao escrever sobre Lydgate, presume, sem citar fontes para essa informação, que os versos da dança francesa tenham saído de algum tipo de "baile de máscaras antigamente celebrado nas igrejas":

These verses, founded on a sort of spiritual masquerade, anciently celebrated in churches, were originally written by one Macaber in German rhymes (....) a french translation was made and written about the walls of Saints Innocents cloisters at Paris: from wich Lydgate formed his English version. ${ }^{235}$

Dois dados se misturam na teoria levantada pelo autor. O primeiro é o manuscrito de Wurzbourg, que teria iniciado a linhagem germânica das danças e que, apesar de datar da década de 1440, pode ser a transcrição ou a cópia de um texto mais antigo. $^{236}$ Talvez Warton pressupunha que esse antigo manuscrito fosse o registro de versos cantados - mas nada se sabe sobre essa hipotética passagem da oralidade para o texto. O segundo dado refere-se ao hábito medieval das festas populares, como os Carnavais, nas quais havia apresentações diversas, de música, dança, mascaradas e teatro:

\footnotetext{
${ }^{234}$ Lydgate In: WARREN, 1931, p. 36-8.

${ }^{235}$ WARTON, section XXI.

${ }^{236}$ conforme capítulo 1 .
} 
Processions of masquers were frequent, and among the traditional theatrical features of the season was a masque of death wich is supposed to have corresponded, on the one hand, to practices mentioned by the classic poets and, on the other, to the mediaeval pageant called "chorea Macchabaeroum" and later the danse macabre. Death was a favorite character in the mummery of the Middle Ages

comenta Joseph Tunison. ${ }^{237}$ As chorea Macchabaeroum, que contavam a história dos irmãos Macabeus, ${ }^{238}$ assim como o uso das máscaras da morte ou de mortos ${ }^{239}$ poderiam, realmente, ter influenciado, de alguma maneira, a elaboração da imagética das danças, na qual os mortos pulam animadamente de mãos dadas com os vivos mas, de novo, ainda não foi possível elaborar sua ligação direta. ${ }^{240}$

Essas conjecturas, portanto, nunca foram confirmadas. Tudo o que se sabe de definitivo, pelo menos até agora, a respeito das danças macabras diz respeito às suas manifestações iconográficas (como afrescos, gravuras, etc) e textuais. "Prácticamente podemos asegurar, desde una perspectiva general, que las Danzas no se pueden considerar dentro de la órbita del teatro medieval" - quem afirma é Victor Infantes, um dos principais estudiosos das danças na contemporaneidade, ${ }^{241}$ ou seja, mesmo no estado atual das pesquisas, nada se comprovou a esse respeito. Mas essas leituras - do Journal d'un bourgeois de Paris e de Warton sobre Lydgate, entre outros exemplos dispersos $^{242}$ - somadas à história criada por Lacroix ajudaram a reforçar essa hipótese de que as danças teriam existido como um espécie de ação teatral, colocando-nos (e aos seus leitores do século XIX) como espectadores do drama supostamente apresentado naquela ocasião. Assim, o imaginário das danças, em especial esse construído no século XIX, ficou indelevelmente marcado pela teoria da existência se suas encenações.

\footnotetext{
237 Para Tunison, as chorea Macchabaeroum deram origem às danças macabras, o que ele afirma na sequência do texto, pelo menos no que diz respeito às suas encenações. (TUNISON, 1907, p. 18) 238 conforme capítulo 1.

239 sobre o uso de máscaras da morte em festividades, ver o capítulo 4, O Carnaval e a Morte.

${ }^{240}$ Ver mais sobre o assunto no capítulo 4, O Carnaval e a Morte.

${ }^{241}$ INFANTES, 1998, p. 119.

${ }^{242}$ Vez ou outra aparecem nos textos estudados menções a possíveis encenações das danças. Na Histoire de René d'Anjou, o autor, M. de Villeneuve, fala de uma que teria ocorrido em 1424 em Paris, nas celebrações do regente Duque de Bedford pela vitória em Verneuil, na qual uma procissão desfilava pelas ruas presidida por esqueleto (de verdade) (in: CLARCK, 1950, p. 14) - essa mesma ocasião é mencioanda por Lacroix, porém como uma masquerade (LACROIX, 1832, p. 25). Emile Mâle fala de um abade Miette que encontrou um manuscrito (que encontra-se na Biblioteca de Rouen, MS 2215, Y39, fol. 69) que afirma que em 1393 foi apresentada, na Igreja de Caubedec, uma "dança macabra" (Male apud UTZINGER, 1996, p. 81). Utzinger e Corvisier têm como certa a história da cena encomendada por Philippe le Bon no hôtel de Bruges, em 1449: um Jeu de la Danse macabre. (UTZINGER, 1996, p. 81; CORVISIER, 1998, p. 23).
} 
De certa maneira, esses debates devem ter influenciado também a Georges Kastner. O teólogo e músico envolveu-se tão profundamente com o tema ao escrever o seu Les danses des morts, dissertations et recherches historiques, littéraires et musicales, publicado em 1852, que decidiu ele próprio compor uma música a partir de versos que encomendou ao amigo e poeta Édouard Thierry.

O fator musical das danças medievais foi central no trabalho de Kastner. Apesar de também nunca ter sido comprovada a existência de um tipo de música executada sobre o tema das danças macabras na Idade Média (pelo contrário, não existe nenhuma evidência de peças musicais ${ }^{243}$ ), o autor dedica um capítulo inteiro de sua obra comentando os instrumentos que aparecem nos exemplares iconográficos - em especial, em uma dança alemã anônima da segunda metade do século XV, Doden Dantz. Trata-se de um conjunto de 41 xilogravuras que encontra-se na Biblioteca de Strasbourg. Seu esquema é parelho ao de G.Marchand, mas quase todas as cenas contêm a imagem de um instrumento diferente e "les instruments y sont figurés d'une manière plus exacte que cela n'a lieu dans d'autres Danses des morts. "244 Seu objetivo, assim, é "tracer une esquisse de l'histoire des instrument de musique employés au moyen âge", ${ }^{245}$ além de analisar e caracterizar as danças macabras daquele período.

A última parte do trabalho, que nos interessa particularmente, é a composição que tem por título La Danse Macabre. Kastner explica no prefácio que não resistiu ao desejo de, ele mesmo, oferecer sua interpretação ao tema estudado:

Je ne pouvais traiter pendant plusieurs années le sujet si poétique et si philosophique de la Danse des Morts sans m'en trouver pénétré au point de désirer l'interpréter musicalement. Je communiquai mon dessein à un poète dinstingué qui, à ma sollicitation, entreprit de paraphraser en charmants vers modernes les vieilles rimes gothiques de la Danse Macabre. ${ }^{246}$

\footnotetext{
${ }^{243} \mathrm{Ou}$, nas palavras de Infantes: no se conserva ningún testimonio musical de ninguna Danza macabra, ni tenemos, tampoco, la más mínima certeza de que nuestro género tuviera en algún momento una constitución musical. (INFANTES, 1998, p. 131)

${ }^{244} \mathrm{O}$ autor continua: J'ai classé tous ces instruments par genres et par familles, et je consacre un chapitre à l'explication de chaque type principal, donnant un aperçu de son origine, de son usage, de ses tranformations, de ses perfectionnements e des différents modèles quíl a produit tant à l'époque où parurent les Danses des morts qu'avant ou après l'apparition de ces danses. (KASTNER, 1852, p. XII) ${ }^{245}$ Idem, inidem, p. XIII.

${ }^{246}$ Idem, Ibidem, p. XIV.
} 
Ao apresentar sua dança macabra, o autor assume a intenção de "rester fidèle au cadre du poème”, repetindo o modelo original. Mesmo assim, seu elenco apresenta mudanças significativas: o primeiro personagem é o imperador, e não o papa, como seria de praxe. Não há intercalação entre religiosos e laicos e estão presentes figuras pouco convencionais como a matriarca e a freira. É uma peça pequena em comparação com as obras do gênero: apenas 6 personagens. O esquema de estrofes também é modificado: as vítimas se manifestam em 8 versos; a Morte, em 4. É, a propósito, uma dança da Morte, e é ela que abre a ciranda, chamando toda gente do mundo a juntar as mãos formando o círculo que é a coreografia de seu baile:

La Mort

Accourez, accourez des quatre points du monde!

Chaque heure dans sa tour rèpète le signal;

Mes fils, joignez vos mains; formez l'immense ronde,

C'est moi qui suis la Mort et qui donne le bal!

O imperador, primeiro a ser nomeado, responde ao chamado com empáfia (“Qui que tu sois, vois ma couronne / Tout un peuple armé m'environne; / J'emplis le monde de terreur, / Après Dieu, je suis l'Empereur!”); a matriarca apela à compaixão (“Je suis la pauvre aïeule / Triste des jours passés / Voici l'hiver; je pleure froide et seule”); o soldado mostra sua experiência em encontrar a morte a cada batalha ("Je suis soldat, vive la danse! / Mon sabre marque la cadence”). O homem rico se vale do poder do seu dinheiro, sugerindo à morte que em seu lugar leve a seus empregados ("plus fier qu'un roi / J'ai des gens qui marchent pour moi./ Síl te faut des danseurs d'élite, / Prends dans les hommes de ma suite”). A criança, tão jovem ainda, que nem sabe andar, é a última da fila ("Je fais à peine un pas; / Comment veux-tu que j'entre dans ta ronde, / Moi qui ne marche pas!"). A cada estrofe em que responde as lamúrias de seus convocados, a Morte determina: "Pas de réplique, il faut danser!" Na sequência dos versos encontram-se as partituras com o acompanhamento musical dos versos composto por Kastner. 


\section{Reinterpretações do modelo das danças na poesia}

O impacto causado pelo encontro com uma dança macabra medieval não era exclusivo dos estudiosos que se dedicaram à ela, muitos poetas e escritores se emocionavam profundamente com a descoberta e se inspiravam em contá-la, ainda que como ficção. Alcides Ducos Du Hauron, em La Danse Macabre au XIXème siècle, poème cabalistique, de 1864 , descreve a experiência.

Na primeira parte do poema, denominado Une fresque, o narrador, vagando à luz do crepúsculo, encontra e adentra as ruínas de palácio medieval, o do fictício Bispo Marcoman. A imagem romântica das construções medievais aparece aqui em toda sua glória: são corredores labirínticos e escuros que dão em um claustro empoeirado e silencioso. Em uma de suas paredes, encimada por arcos góticos, ele reconhece formas desenhadas e se aproxima. Revela-se diante de seus olhos um afresco cuja aparência "formidable autant que pittoresque, I glaça la moelle de mes os". Ele sabe do que se trata pois conhece as gravuras de Holbein: "C'était la Danse Macabrée”. É curioso como o autor adota uma das denominações antiquadas das danças, "macabrée", antes da prevalência do termo macabre, conforme aparece no poema de John Lydgate, por exemplo - talvez para assinalar o quanto é antiga a pintura que descreverá.

A Morte é retrata com características que mesclam elementos da estética macabra e dos Trinfos da Morte: ela é majestade ("Sa majesté la Mort festoyait ses sujets”) e é ainda carniça (“Une pourpre en lambeaux drapait ses omoplates. / Aux loques de sa chair, noires comme le jais, / Cet oripeau mêlait des loques écarlates.”). Os personagens do afresco são tais como nas obras tradicionais; as hierarquias se misturam, os mais pobres, "rebut du genre humain”, de mãos dadas com "plus grands monarques du monde", e todos rodam e pulam ao integrar a dança - a Morte parece se comprazer dessa igualdade possível somente nessas circusntâncias.

Ducs, barons, chambellans, sénéchaux et vidames Tourbillonnaient avec les derniers des manats. Les femmes de roture et les plus nobles dames S'esbaudissaient ensemble en des bond surprenants.

Ceux qui furent en proie à la misère immonde, Les gueux, de leur vivant, rebut du genre humain, 
Pour danser côte à côte avaient pris par la main

Les plus grands monarques du monde.

O narrador parece sugerir que o autor desta obra que tanto admira talvez seja o próprio Holbein (“Holbein, de son pinceau railleur, / Entremêlant les tous d'une double palette [...]"). Fala do pregador, que abre o desfile com seus versos ("Spectatuer attentif du monstreux ballet, / Ce poète semblait, sur un ton sarcastique, / Célébrer en ses vers la danse frénétique”). Ao fim da segunda parte, acontece o que essa atmosfera lúgubre prenunciava: o pregador, figura pintada no afresco, começa a se movimentar, "se détacher du mur et s'avancer vers moi! / Ce n'était pas un corps vaporeux et subtil, / Mais un être tangible et presque de ce monde." A aparição, ganhando a confiança do narrador, o leva em um vôo místico ao redor do planeta, no qual se vê a humanidade inteira, os átomos e o cosmo. Na descida, o narrador é surpreendido ao se ver no meio de uma dança macabra alucinante e gigantesca, da qual participa uma multidão de personagens. Depois da experiência quase onírica, eles retornam ao claustro.

Para além das obras que emulam as danças macabras medievais em seus elementos plásticos (um conjunto de vivos representantes de estratos diversos da sociedade, sendo levados por cadáveres dançarinos ou a Morte personalizada) e simbólicos (a hierarquização social, a igualdade de todos diante da morte que é inevitável e repentina, a corrupção do corpo) mais característicos, o século XIX assistiu também a uma reinterpretação do tema que ora rememora as obras originais, ora trabalha com operadores distintos, redefinindo a idéia das danças.

Em Bouchers et tombeaux, de Théophile Gautier, publicado em 1852, no livro Émaux et camées, a alusão ao que se passa por baixo da terra após o enterro é significativa do interesse do autor pelo macabro, já demonstrado em obras anteriores, como em La comèdie de la Mort. De acordo com o poema, o esqueleto "était invisible / Au temps heureux de l'Art païen" pois os homens de antanho, admiradores do belo, não o procuravam, não abriam as tumbas para observar a ação do tempo sobre os despojos humanos. Mas, na segunda estrofe, ou seja, na continuidade do percurso histórico, em épocas cristãs, a pedra tumular se rompe e revela o resto mortal, o esqueleto, que se desvencilha de suas carnes como de uma vestimenta - ainda que reste "une pincée entre les doigts, / Résidu léger de la vie”. Ele, então, se levanta e se prepara para começar os trabalhos, conduzindo, como de praxe, primeiro o imperador, depois o papa e o rei: 
Il pousse à la danse macabre L'empereur, le pape et le roi Et de son cheval qui se cabre Jette bas le preux plein d'effroi

Como em um itinerário initerrupto, este "hôte inattendu”, "squelette gothique”, carrega consigo ainda a cortesã ("Il entre chez la courtisane"), o doente ("Du malade il boit la tisane”), o avarento (“De l'avare ouvre le tiroir"), o camponês (“Du laboureur à la charrue / Termine en fosse le sillon”), a noiva ("Vole à la pâle mariée / Sa jarratière de ruban"), aumentando seu séquito a cada passo:

A chaque pas grossit la bande;

Le jeune au vieux donne la main;

L'irresistible sarabande

Met en branle le genre humain.

O esqueleto, emissário da morte, não poupa ninguém que atravessa seu caminho, fazendo os opostos darem as mãos: são todos iguais em sua dança. $\mathrm{O}$ autor evoca Hans Holbein, sugerindo que seu protagonista se parece tal como o desenharia o mestre alemão (“Holbein l'esquisse d'un trait sec”).

O instrumento tocado pelo esqueleto é, de novo, a rabeca ("Dansant et jouant du rebec"). Tipo de violino que se toca com arco, a rabeca frequentemente aparecia nas danças medievais, usado pelos cadáveres-músicos - sua presença no poema de Gautier sendo, portanto, uma clara alusão à elas. Segundo Kastner em seu estudo sobre os instrumentos musicais das danças macabras iconográficas, a rabeca era usada pour faire danser, isto é, era tocada para se dançar. Seu uso era comum nas festas burguesas e nas festas populares, urbanas ou campestres e, ainda com Kastner, era conhecida tanto no Oriente como na França, Grã-Bretanha, Alemanha, Russia, Italia e Espanha: “on l'employait dans les noces, les bals, les festins; dans les macarades, les cortéges, les sérénades, et en general dans tous les divertissements du peuple et de la bourgeoisie. "247 Ora, a rabeca é o mesmo instrumento tocado por Macabre, a figura infame criada por Lacroix, que teria inventado a dança macabra. Segundo o autor, a fama de Macabre era de que ele tinha o poder de acordar os mortos ao som de sua

\footnotetext{
${ }^{247}$ KASTNER, 1852, p. 250.
} 
rabeca que, supostamente, era também ouvida por aqueles que estavam à beira da morte: "Aucuns disaient que le rebec de Macabre réveillait les morts au clair de lune; aucuns racontaeint les prodiges opérés par cet instrument, qu'on n'entendait pas sans être menacé de mort prochaine. "248

Kastner comenta a expressão "visage de rebec", recorrente na França da Idade Média Tardia, que faz alusão ao tipo de ornamento que decorava o braço da rabeca, geralmente uma cabeça esculpida diretamente na madeira - e que não necessariamente eram figuras grotescas ou ridículas, mas poderiam ser belos rostos de mulheres (no entanto, o autor deixa claro que a expressão era pejorativa, assim como a utilizou Rabelais, no epitáfio de Gargântua à sua mulher Babedec: "Elle en mourut, la noble Babedec / Du mal d'enfant; que tant me semblait nice: / Car elle avait visage de rebec, / Corps d'Espagnole et ventre de Souice"249). A rebeca de Macabre, de Lacroix, é "bizarrement orné d'une tête de mort."

Em dado momento, Macabre toca no pequeno instrumento uma música melodiosa, com "as modulações dos soluços, dos choros e dos suspiros", que se propagava como "uma prece celeste". A melodia desencadeia sensações oníricas e fantásticas, fazendo Macabre entrar em uma espécie de transe. Ao fundo, ouve-se as batidas dos sinos, que dão início à eventos admiráveis:

\begin{abstract}
Alors le rebec du ménétrier éclatait en sons plus âpres et plus mystérieux. Les charniers s'agitaient autour du cimetière, dont le terrain était soulevé par la puissance de l'instrument; et tandis que les obélisques, les croix et les monumentcédaient au vertige général, une multitude croissante d'ombres et de spectres s'avivait, se mêlait, s'envolait avec la rapidité de l'éclair. la lune, emportée parmi les nuages, présidait à ces ébats muets, et Macabre se laissait entraîner en esprit à la fête qu'il donnait aux morts. ${ }^{250}$
\end{abstract}

A referência ao imaginário medieval também é clara no poema de Anatole France, La Danse des Morts, publicado em 1873. O autor foi um apaixonado pela cultura daquela época, tendo inclusive escrito sobre Rabelais. A primeira estrofe

\footnotetext{
${ }^{248}$ LACROIX, 1832, p. 26.

${ }^{249}$ RABELAIS, s/d, p. 147.

${ }^{250}$ LACROIS, 1832, p. 36.
} 
sinaliza a idealização do período que percorre todo o poema, chamado de "siècles de foi":

Dans les siècles de foi, surtout dans les derniers,

La grand'danse macabre était fréquemment peinte

Au vélin des missels comme aux murs des charniers.

Para o autor, as danças eram imagens "edificantes e santas", que davam esperança diante da idéia da morte e, sendo assim, a gente as olhava sem medo.

Je crois que cette image édifiente et sainte

Mettait un peu d'espoir au fond du désespoir,

Et que les pauvres gens la regardaient sans crainte.

Percebe-se aqui, por parte do autor, uma concepção de morte que não é a medieval (que não era de desesperança, pelo contrário, a morte era passagem, caminho para a vida eterna). Na sequência, France fala da morte como a escuridão total ("Pour eux, mourir, c'était passer du gris au noir"), um "nada" (a imagem de um morto e um vivo dançando pode ser apavorante, mas menos do que o nada: "Le branle d'un squelette et d'un vif sur un gouffre;/ C'est bien affreux, mais moins poutant que le néant”), revelando um entendimento de morte bastante característico de seu tempo, das sociedades urbanas e industriais do século XIX.

France constrói um contexto romantizado no qual as danças eram pintadas por monges “à genoux et priant”, que nelas sabiam projetar “la paix du monastère”. Diante daquelas imagens, "on sent communier en Dieu toute âme humaine, / On sent encore la foi, l'espérance et l'amour". E, retomando o modelo medieval, descreve essa obras nas quais as vítimas se resignam diante da Morte ("les mourants sont pensifs, mais ne se plaignent pas"; "et tout le peuple suit dans une paix profonde”). Os primeiros da fila, como sempre, são o Papa e o Imperador. O Barão e o Lavrador "vont illuminés d'horreur." A jovem virgem se assusta quando, com um movimento ágil de braço, "le squelette lui prend la taille en amoureux", a quem ela se entrega, "les cils clos, aux bras du danseur aux yeux creux." O cavaleiro errante é também acometido por um emissário da morte - no seu caso, emissária, uma "étrange dame", de cujos ossos pende "un reste 
noir de peau qui fut un sein de femme." O pajem entra na dança seguro que vai para o inferno "car il sait clairement que sa dame est damnée." E o mendigo cego, que fecha o desfile, além de não conseguir seguir a dança apropriadamente, ainda é alvo de gracejo da Morte, que "coupe tout doucement la corde de son chien."

A música também está presente na composição: um dos esqueletos, usando um chapéu que esconde sua fronte branca como mármore, toca o bandolim que dá ritmo à roda, tocando "une musique un peu faible et presque câline" que "Marque discrètement et dolemment le pas." Outro esqueleto, que ainda tem restos de pele entre os dedos, toca a flauta. E ainda outro, de mulher, um clavicórdio.

Todos aqueles que respondem ao chamado da Morte crêem que um dia acordarão, pelos sons e clarões do Julgamento, que "agiteront leurs os d'un grand tressaillement." Os corpos ressucitados de toda criatura surgirão sobre os túmulos; neste dia "La Mort mourra (...) Lorsque l'Eternité prendre tout l'univers." Assim, alguns subirão ao céu e outros sofrerão no Inferno - mas de qualquer maneira, "ils vivront encor!"

Novamente, France aponta para o paradoxo entre a sua época e as crenças medievais. Para os homens de antanho, a vida continua: gozando das delícias eternas ou sofrendo as penas eternas - a Eternidade é um pressuposto. Não é assim que pensa a contemporaneidade, e daí a ironia do autor no último verso do poema: "Oh! bienheureux ceux-là qui croyaient à l'Enfer." Novamente, têm-se o contraponto do "nada", da morte racionalizada dos oitocentos.

Vê-se no poema de France uma atualização do sentido da morte. A instrumentalização do tema macabro para se falar do contexto específico do século XIX também ocorre no poema Mors, de Victor Hugo, escrito entre 1848 e 1852, publicado no segundo volume de Les contemplations. O poema, de uma única estrofe, faz referência aos conflitos da chamada Primavera dos Povos naqueles anos, que teriam transfomado a capital francesa em uma "Babilônia". O narrador fala da Morte que começava a atuar pelos campos avidamente, "à grand pas”, e vai se aproximando da cidade - onde os "poderosos", o "trono" e o "ouro" estavam. A devastação é completa; o povo, confuso e perdido na sombra, onde tudo é dor e luto ("Les peuples éperdus semblaeint sous la faulx sombre / un troupeau frissonnant qui dans l'ombre s'enfuit; Tout étair sous ses pieds deuil, épouvante et nuit."). Mas a Revolução era uma causa 
justa e, apesar de toda destruição, sua luta não era vã - atrás da Morte, um anjo sorridente, banhado de uma luz cálida, segura em suas mãos todas as almas ("Derrière elle, le front baigné de douces flammes, / Un ange souriant portait la gerbe d'âmes"). O contraste do calor trazido pelo anjo é enfatizado pelo vento gélido que balança as mortalhas que cobrem os corpos.

O poeta faz um retrato impressionante da Morte como a grande ceifadora, que se relaciona diretamente com a imagem dos Triunfos da Morte, cujo precedente encontrase na personalização da Morte nas danças macabras, como visto anteriormente. Logo no início ela é assim apresentada: passa abatendo a todos com golpes de foice, com eficácia e velocidade (“Je vis cette faucheuse. Elle était dans son champ./ Elle allait à grand pas moissonnant et fauchant"). Impiedosa, diante dela, os poderosos caem; tudo em seu caminho ela transforma: a Babilônia (que é Paris) em deserto, o trono em cadafalso (a monarquia deposta), as rosas em estrume, as crianças em pássaros, o ouro em cinzas.

As mães, cujos olhos ela converte em cursos d'água ("les yeaux des mères en ruisseaux"), gritam ao entregarem-na seus filhos, e perguntam o motivo de terem nascido se deviam morrer ainda tão jovens: "Et les femmes criaient: - Rends-nous ce petit être. / Pour le faire mourir, pourquoi l'avoir fait naître?" A criança sempre foi personagem indispensável às danças macabras pois sua presença simboliza o aspecto universalizante da morte, que nem os pequenos seres poupa. Basta lembrar aqui, do exemplar de G. Marchand, no qual o bebê que sequer fala, apenas balbucia " $a$. $a$. $a$. $a$ ", recebe a visita da faucheuse.

Uma curiosidade do poema de Hugo é a caracterização da morte como "noir squelette" que não é nada usual. Remete à sujeira dos ossos em contato direto com a terra, contrapondo a branca luz da lua ao negrume do mundo, à malignidade frequentemente associada à cor preta. Na Doutrina das cores, de 1810, Goethe defendia que a cor era mais do que um fenômeno físico provocado pela incidência da luz na superfície das coisas - teoria newtoniana, muito debatida pelo escritor alemão. Para além do dado empírico, era necessário, segundo ele, aliar esse conhecimento factual à construção de uma linguagem moral que se estabelecia no contato entre a cor e os olhos humanos - que não eram instrumentos passivos como as lentes usadas em laboratórios, mas partes ativas do organismo, que, mais do que receberem mecanicamente as cores, as interpretam. Assim, o "caráter" de uma cor se revelaria à alma humana, nenhuma delas sendo absolutamente neutra, mas despertando uma paixão e obtendo uma reação. Cores seriam conceitos: desta maneira, o preto, além de ser a falta de luz (fenômeno 
físico) era, principalmente, conceito, idéia de escuridão, de ausência. Daí o paradoxo de se ter um esqueleto negro; os ossos que deveriam ser brancos sob a luz, são, na verdade, escuros como a terra, a fossa, a noite e a morte.

Mas é no Promontorium Somnii, excerto do William Shakespeare (1864), que Victor-Hugo, em suas divagações sobre a literatura, nos apresenta uma imagem lancinante de dança macabra, grotesca, que ele oferece como exemplo de um "quimerismo gótico". ${ }^{251}$ A alegoria começa com a tarântula, que ataca e envenena os homens. Desesperados, aqueles picados por ela se põem a dançar initerruptamente em ciranda, até gastarem os pés, em seguida as canelas, depois os joelhos e os ossos das coxas. Cotocos, dançam sobre seus troncos até que também eles gastem. Finalmente, os dançarinos não passam de cabeças saltitantes, com restos de costelas grudados ao redor do pescoço, como se fossem patas, parecendo, então, com... tarântulas. A aranha, assim, lhes fez aranhas. As cabeças-tarântulas, em roda, cavam a terra e desaparecem:

Ceux qu'elle a iqués se cherchent, se trouvent, se prennet par la main et se mettent à danser la ronde qui ne s'arrête pas; les pieds s'y usent; les pieds usés, on danse sur les tibias; les tibias s'usent, on danse sur les genoux; les genoux s'usent, on danse sur les fémurs; les fémurs s'usent, on danse sur le torse devenu moignon; le torse s'use, et les danseurs finissent par n'être plus que des têtessautelant et se tenant par les mains, avec des tronçons de côtes autour du cou imitant des pattes, et l'on dirait d'énormes tarantules; de sorte que l'araignée les a faits araignées. Cette ronde de têtes use la terre, y creuse um cercle horrible et disparaît. ${ }^{252}$

O mal, relacionado ao baile dos mortos, aparece também no poema em prosa $L a$ Danse des Morts, de Gustave Flaubert, de 1838. O texto, escrito quando o autor tinha apenas 17 anos, tem por fio condutor um diálogo entre Satã e Jesus Cristo. As duas poderosas entidades conversam em tom amigável e irônico sobre suas respectivas influências na humanidade. Cristo crê que sua história e seu exemplo são ainda fortes

\footnotetext{
${ }^{251}$ Qu'on nous permette ce mot: "chimérisme". Il pourrait servir de nom commun à toutes les théogonies. Les diverses théogonies sont, sans exception, idolâtrie par un coin et philosophie par l'autre. Toute leur philosophie, qui contient leur verité, peut se résumer par le mot Religion; et toute leur idolâtrie, qui contient leur politique, peut se résumer par le mot Chimérisme. Cela dit, continuons. Dans le chimérisme gothique, l'homme se bestialise. La bête, don't il se rapproche, fait un pas de son côté; elle prend quelque chose d'humain qui inquiète. (HUGO, 1864, p. 317).

${ }^{252}$ HUGO, 1864, p. 317-8.
} 
para o homem, mas Satã quer convênce-lo do aumento de seu império em um mundo cada vez mais dedicado à luxúria e à destruição.

A “dança dos mortos" do título se justifica em dois momentos da narrativa: quando o príncipe do Inferno, para demonstrar suas habilidades, conta ao filho de Deus que tem por hábito fazer dançar seus discípulos depois de mortos. Por quê? - pergunta o Cristo - "tu persécutes encore les cadavres?” Para sua diversão, responde Satã: "Cela m'amuse." 253

O texto inicia em uma dessas cenas. Fica claro que algo os desperta, que eles respondem a um chamamento, algo que funciona como um estopim, um ponto de ruptura: “À la danse, les morts!”, é a primeira sentença. A natureza reage e eventos fantásticos se revelam: "le cel se couvre de nuages noirs, les hiboux volent sur les ruines et l'immensité se peuple de fantômes et de démons". As tumbas se abrem e os esqueletos se arrumam, "[ils] défont leurs linceuls que la terre a collés sur les os."

Automaticamente, "ils se lèvent, ils marchent, ils dansent"(o mesmo acontece na dança de Ducos du Hauron, em que o narrador compara os personagens à autômatos “horribles automates”). Parecem nem ser mais humanos; não mais vivem, sua existência é o Nada, infinito :

Dansez maintenant que vous êtes morts, maintenant que la vie et le malheur sont partis avec vos chairs. Allez! vos fêtes n'auront plus de lendemain, elles seront éternelles comme la mort; dansez! réjouissez-vous de votre néant! Pour vous plus de soucis ni de fatigues, vou n'êtes plus; pour vous plus de malheurs, vous êtes morts. Oh! les morts, dansez! $!^{254}$

Mais à frente, uma segunda dança tem início. Nela, a Morte, cúmplice compulsória de Satã, toca a rabeca para que os mortos acordem e se movimentem: "Satan m'ordenne et un pouvoir dont je ne connais pas que la force m'enchaîne à sa volonté; les morts vont se réveiller." 255 Seus mestres acompanham sua performance e observam com tristeza o início dos eventos ("Satan était immobile comme la statue du

\footnotetext{
${ }^{253}$ FLAUBERT, 2001, p. 11.

${ }^{254}$ Idem, ibidem, p. 2.

${ }^{255}$ Idem, ibidem, p. 47.
} 
désespoir, regardant la plaine (...) Le fils de Dieu aussi avait la tête penchée sur sa robe, ses yeux étaient remplis de larmes d'argent (...) Rempli d'une melancolie sublime, pleine de mélodie et de chants de l'âme, il se taisait $\left.{ }^{, 256}\right)$.

No texto, a Morte, apesar de soberana sobre a vida (“j’ai tout fauché, abattu, brisé, trônes, peuples, empereurs, pyramides, monarchies ${ }^{, 257}$ ) é mostrada como uma figura abatida, fatigada ("Quand donc, o Dieu, dormirai-je à mon tour? quand pourraije, comme un fossoyeur, m'endormir sur mes tombes?",258). Ela não é o esqueleto, tampouco uma entidade abstrata, mas sua caracterização não é exata; ela parece um tipo de transi, um corpo sem carne, de pele lívida e de cor terrosa, cabeça quase limpa, não fossem algumas mechas resistentes de cabelo ruivo, de olhos firmes e devoradores mas de voz doce e cansada. ${ }^{259}$

Nessa segunda dança, retoma-se a referência padrão do tema com uma diferença importante: os personagens já estão mortos e são acordados, passando a agir exatamente como estavam no momento em que morreram. Saídos da terra, confusos, encontram a Morte, que lhes chama por sua antiga posição social. Em um cenário que lembra uma espécie de Inferno, um "deserto vermelho sem limites"260, sob a vigilância oculta de Cristo e de Satã, misturam-se na cena diversas concepções antigas da morte além das danças macabras, como os Ars Moriendi (o pobre que é tentado e se volta ao diabo), os revenants e o Juízo Final. Aterrorizados e desejosos de voltar à vida, são todos conduzidos à ciranda, que todos iguala e todos carrega:

Les morts dansaient et la longue file de squelettes tournait et tourbillonnait en un immense spirale qui montait júsqu'aux hauteurs les plus hautes et descendait jusquáux abîmes les plus profonds. Là, le roi donnait la main au mendiant, le prêtre au bourreau, la prêtesse à la courtisane, car tout se confondait dans ette égalité souveraine du néant. Les squelettes se ressemblaient tous; mendiants, souverains, jeunes et vieux, beauté et laideur, tout se confondait là; la danse était longue et la foule joyeuse. ${ }^{261}$

\footnotetext{
${ }^{256}$ Idem, ibidem, p. 54.

${ }^{257}$ Idem, ibidem, p. 39.

${ }^{258}$ Idem, ibidem, p. 45.

${ }^{259}$ Idem, ibidem, p. 53.

${ }^{260}$ Idem, ibidem, p. 54.

${ }^{261}$ Idem, ibidem, p. 77.
} 
Para que não se credite esse retorno das danças macabras no século XIX apenas aos poetas franceses, até mesmo Sir Walter Scott escreveu a sua. O escritor romântico britânico mais conhecido no continente europeu à sua época, foi um profundo estudioso da história da Escócia, colecionando exemplares de baladas populares que publicou com o título de Minstrelsy of the Scottish Border, em 1803. Foi muito influenciado pela vertente medievalista da literatura romântica do fim do século XVIII, em especial pelos romances góticos, com os quais aprendeu a misturar informações históricas verídicas com ficção, em uma linguagem agradável ao leitor. ${ }^{262}$ De sua curiosidade pela Idade Média, é possível que tenha tido contato com a arte macabra, a ponto de intitular um poema seu de 1815 como The dance of death. Formalmente, o texto em nada lembra os poemas medievais, tendo já a estrutura das danças românticas. O pano de fundo é político; o poeta canta o campo de batalha, aludindo a uma série de batalhas, como as de Quatre-Bras e Waterloo, ambas em junho daquele ano, mas também à batalha de Flodden, em 1513.

O ambiente bélico, o ataque inimigo inesperado, as frias noites passadas nos fronts, parecem ser propícias para o aparecimento de entidades fantasmagóricas que anunciam a morte. É quando sons quase indistintos se propagam na escuridão - o barulho do casco de um corcel que se aproxima, "the frequente clang of courser's hoof" (quem o cavalga? Provavelmente a Morte, cavaleira e indomada, como nos Triunfos), ainda inaudível ao sentinela, que tampouco percebe a chegada de invisíveis vultos. De súbito, como meteoros, os fantasmas se revelam em uma ciranda ruidosa, condenando todos que estão a sua volta:

Wild as marsh-born meteors glance, Strange phantoms wheeled a revel dance, And doomed the future slain. ${ }^{263}$

A visita se repete nos acampamentos, prenunciando a tragédia do confronto final: um bando de espectros que, de mãos dadas, dançam em círculo, em turbulenta folia:

\footnotetext{
${ }^{262}$ VAILLANT, Dictionnaire du Romantisme, 2012, p. 684, verbete “ Walter Scott".

${ }^{263}$ SCOTT, 1869, p. 482.
} 
An indistinct and phantom band,

They wheeled their ring-dance hand in hand,

With gesture wild and dread.

$(\ldots)$

And still their ghastly roundelay

Was of the coming battle-fray

And of the destined dead. ${ }^{264}$

\section{Criações oitocentistas}

Apesar dos casos em que o modelo medieval das danças macabras é citado, o século XIX também produziu obras que ressignificaram o tema. Esses exemplares, mesmo fazendo referência à tópica original (e, nesse sentido, cabe mencionar que muitos são intituladas "Dança macabra" ou "Dança dos mortos"), modificaram completamente seu conteúdo. A narrativa, via de regra, se passa, agora, em um cemitério. Ao som das badaladas da meia-noite, os cadáveres saem de suas sepulturas para confraternizar - e não mais como agentes da morte, para encaminhar os vivos a óbito. Já quase não há, aliás, vivos - estes, quando presentes, assumem o papel de espectadores, espécies de testemunhas de eventos tétricos, registrados pelo relato que se lê. Essas danças perdem o caráter didático, pedra de toque das danças de antanho. Seu objetivo não é mais mostrar os representantes da sociedade, nem mesmo atentar sobre a universalidade e a inesperabilidade do fim -, seu enfoque é o encontro dos mortos e seus caracteres fantasiosos e terroríficos (brumas, defuntos que voltam à vida no meio da escuridão da madrugada, etc).

Emblemática dessa nova configuração é Der Totentanz, de Goethe (citada, aqui, em sua tradução para o inglês, The dance of death). Escrita em 1813, provavelmente inspirou muitos outros autores a recorrerem ao imaginário das danças. $\mathrm{Na}$ balada goethiana, ao repicar dos sinos à meia-noite, em um cemitério conjugado a uma igreja, sob a intensa luz prateada da lua, os cadáveres de homens e mulheres acordam e se levantam, abrindo suas sepulturas. Suas mortalhas brancas como a neve se arrastam no chão. Um guarda a tudo assiste, do alto de uma torre "de ornamentos góticos":

\footnotetext{
${ }^{264}$ SCOTT, 1869, p. 483.
} 
The warder looks down at the mid hour of night,

On the tombs that lie scattered below:

The moon fills the place with her silvery light,

And the churchyard like day seems to glow.

When see! first one grave, then another opes wide,

And women and men stepping forth are descried,

In cerements snow-white and trailing. ${ }^{265}$

Jovens e velhos, pobres e ricos: estão todos ansiosos para o começo da festa. Eles esticam os tornozelos e rodopiam alegremente ("In haste for the sport soon their ankles they twitch,/ And whirl round in dances so gay;/ The young and the old, and the poor, and the rich"). As mortalhas atrapalham seus movimentos e como já não se sentem constrangidos por seus corpos, eles se balançam e os panos caem sobre os túmulos ("But the cerements stand in their way;/ And as modesty cannot avail them aught here,/ They shake themselves all, and the shrouds soon appear / Scattered over the tombs in confusion.").

Livres de seus trajes mortuários, podem agitar as pernas e as coxas. Um marca o ritmo com batucadas; outros, tocam chocalho. É essa imagem do rendez-vous macabro, sem intenção segunda além do divertimento dos mortos, a novidade que encerra o poema. Não há lição a ser aprendida ou moral a ser ensinada. A algazarra se torna cenário para o conflito que se dá entre o guarda e um dos defuntos, que tem seu sudário roubado por aquele. Aqui, vê-se que a intromissão do único vivo presente à cena é fatal. Diferente das danças medievais que imprescindem da participação dos vivos, Goethe mostra que no novo festim dos mortos não há espaço para eles.

É de se supor que o poeta alemão conhecia as danças macabras medievais e teria até mesmo tido contato com elas. Segundo Henri Stegemeier, em carta escrita em Berne para Johann Heinrich Merck, de 17 de outubro de 1779, ele conta que viu as gravuras de Hans Holbein na Basiléia - apesar de não articular mais nada a respeito, nem mesmo mencionar a famosa dança pintada naquela cidade. ${ }^{266}$ É interessante que, apesar disso, o poema de Goethe não lembre em nada a estrutura da dança de Holbein, sequer de outras obras do gênero:

\footnotetext{
265 GOETHE, 1874.

$266 \mathrm{Na}$ verdade, a dança do convento dominicano da Basiléia foi totalmente destruída em 1805; no entanto, era uma obra bastante conhecida do gênero e atração turística da região, a ponto de ter diversas réplicas em exposição. Ficava em um muro interno do cemitério e, apesar de derrubada, sobraram muitas reproduções e descrições, em manuscritos e impressos. Diz-se que Hans Holbein teria se impressionado tanto com seu tema e sua monumentalidade que se inspirou para fazer tanto seu Alfabeto da morte quanto os Simulacros. Ver a seguir, no capítulo 4.
} 
If we need attempt some explanation for this, it is as simple perhaps as to say that Goethe was merely following the tastes and trends of the age itself, in wich the influence of the Totentanze has died out (...) there seems to have been little or nothing in the powerful presentation of the theme in art or literature wich appealed to Goethe.$^{267}$

Em outra carta, desta vez a Christiane Vulpius, sua esposa, enviada de Dresden em 21 de abril de 1813, Goethe conta que teria feito versos inspirado por uma "Todtentanzlegende" que seu cocheiro havia lhe contado alguns dias antes, e enviava o poema a seu filho August, apenas 5 dias depois. Uma cópia fora mandada também ao Príncipe Bernhard de Weimar, a quem ele dedicava a balada. De acordo com Stegemeier, a tal história contada pelo empregado provavelmente misturava elementos do folclore alemão (lendas da Boêmia e da Turíngia, eventualmente) com contos da tradição oral de contos sobre fantasmas, mortalhas roubadas e mortos que dançam. ${ }^{268}$

"The antologies do not often include Goethe's Totentanz; yet it is certainly one of his finest ballads with its many effective contrats (lights and darks, humor and tragedy, reality and supersitition and imagination, horror and drollery)", comenta ainda Stegemeier. ${ }^{269} \mathrm{O}$ valor do poema, apesar de não figurar nas antologias, parece ter sido reconhecido, ao servir de inspiração assumida para vários compositores, ${ }^{270}$ entre eles, Franz Liszt, cuja Totentanz é, seguramente, uma de suas composições mais conhecidas. Curiosamente, a peça de 1838 , tem como base a melodia do hino gregoriano de Dies Irae, sobre o Julgamento Final, ou seja, se nem a balada goethiana se referia às danças macabras propriamente ditas, o mesmo ocorria com o trabalho de Liszt.

Assim, como no modelo inaugurado por Goethe, outras obras aparecem sob o título ou a premissa dessa nova "dança macabra". Uma delas se tornou muito conhecida por ter gerado, também por sua vez, um poema sinfônico composto pos Camille SaintSaëns. Trata-se da Danse Macabre, do simbolista Henri Cazalis. O texto, de 1874, é de

\footnotetext{
267 STEGEMEIER, 1949, p. 582 e 587. O autor atenta para o fato de que, apesar de frequentemente comentar seu trabalho em cartas, diários e outros documentos pessoais, a Totentanz de Goethe foi mencionada pelo autor apenas nas cartas citadas. Assim, são elas as únicas fontes de informações sobre sua produção.

268 STEGEMEIER, 1949, p. 582.

${ }^{269}$ STEGEMEIER, 1949, p. 584.

${ }^{270}$ Stegemeier ainda cita K.F. Zelter, C. Löwe, B. Klein, O. Ludwig, W.H. Veit, L. Berger, V. A. Loser. (1949, p. 584.)
} 
extraordinária musicalidade, tanto no ritmo dos versos quanto nas onomatopéias. Neste caso, temos a presença da morte e de seus companheiros esqueletos. Em uma madrugada de inverno, à meia-noite, ela surge, tocando seu violino, com um air de danse, acordando os mortos:

Zig et zig et zig, la mort en cadence

Frappant une tombe avec son talon, La Mort à minuit joue un air de danse, Zig et Zig et Zag, sur son violon. ${ }^{271}$

Eles levantam, "courant et sautant sous leurs grand linceuls.” O baile animado faz com que seus ossos se choquem (“On entend claquer les os des danseurs”). Cazalis retoma o tema da igualdade de todos diante da morte: os esqueletos sem misturam e se divertem sem distinção. A antiga madame se entrega lascivamente a um artesão, enquanto um rei saltita alegremente com um camponês; todos se dão as mãos e formam círculos. "Et vive la mort et l'égalité!" - proclama o último verso. A sarabanda termina de súbito, os mortos fogem ao cantar do galo.

Tendo a referência do texto de Cazalis, Saëns desenvolve sua Danse Macabre no mesmo ano de 1874. Essa é possivelmente uma das obras mais conhecidas produzidas no século XIX sobre o tema das danças. Ela começa com doze toques de harpa representando as batidas da meia-noite. Os solos de violinos fazem as vezes da Morte e o xilofone emula o bater de ossos que a coreografia dos esqueletos emite.

No caso de El estudiante de Salamanca, de Espronceda, publicado em Poesías, de 1840, o poeta espanhol evoca a dança dos mortos em três momentos. No início do poema, a cidade de Salamanca, "insigne em armas y letras, / patria de ilustres varones, / noble archivo de las ciencias" é também palco de eventos fantásticos. Segundo as antigas histórias contavam, depois da meia-noite, momento em que todos descansam e que as torres das igrejas e o castelo gótico parecem fantasmas na paisagem, sob o céu sombrio e sem estrelas, nesta hora "temerosas voces suenan / informes, em que se escuchan / tácitas pisadas huecas, / y pavorosas fantasmas / entre las densas tinieblas / vagan”. Esses eram os sinais de que "los muertos la tumba dejan." E foi em uma noite

${ }^{271}$ Danse Macabre, 1879, p. 2. 
assim que se passou o drama do jovem conquistador Don Félix de Montemar, cujo desenrolar ocupa o seguimento do poema.

$\mathrm{Na}$ quarta parte, após matar em duelo o irmão de uma virgem que seduzira e que morreu de tristeza pela desilusão amorosa, Don Félix, o "estudiante endiablado", segue uma misteriosa e diáfana figura feminina por um devaneio de infinitas ruas e praças, castelos, templos e torres. Em seu caminho, ocultos sinos dobram e ao seu redor "cien espectros I danzan con torpe compás", realizando passos de umas "danzas grotescas", como um "estruendo funeral". O funeral era o do próprio Félix, que vê a si mesmo, cadáver, sendo velado.

Por fim, uma vez mais os mortos retornam, agora para o casamento de Montemar com a a indistinta figura de mulher. "Lúgubres sonidos" aproximam-se, num crescendo, elevando-se acima do quebrar bravio do mar e de trovões que anunciam a tempestade. Sente-se o ruído de ossos batendo, o rangido de dentes e as pedras que se rompem - são as louças tumulares erguendo-se do chão em um "pavoroso estallido". Pouco a pouco a terra de abre e escutam-se os crânios que se chocam, "ya descarnados y secos", saírem de sua morada eterna com "algazara y gritería”: "todo em furiosa armonía / todo em frenético estruendo, / todo em confuso trastorno , / todo mesclado y diverso." Mais de cem vultos aproximam-se do jovem conquistador espanhol, para testemunhar o tétrico enlace. O fantasma de Elvira lhe oferece sua mão, "y era su tacto de crispante hielo / y resistirlo audaz intentó em vano", "galvánica, cruel, nerviosa y fría, / histérica y horrible sensación”. A noiva anuncia a consumação da aliança “ ¡Es esposo!” - ao que reagem jubilosos os espectros: “iEs el esposo de su eterno amor!”

Ela afasta o véu que lhe cobre o corpo e o que Félix contempla lhe enche de pavor: "uma sórdida, horrible cavalera":

El cariado, lívido esqueleto, los fríos, largos y asquerosos brazos, le enreda en tanto en pretados lazos, y ávido le acaricia en su ansiedad: la boca a Montemar, y a su mejilla la árida, descarnada y amarilla junta y refriega repugnante faz. ${ }^{272}$

${ }^{272}$ ESPRONCEDA, 2014, p. 70. 
Banhado em suor, o noivo resiste em vão - um misto de repugnância e volúpia inesperada se fundem nele diante das investidas: "y cuanto más airado forcejea, / tanto más se le junta y le desea." Enquanto isso, os mortos festejam, como é de praxe, dançando, formando círculos em assombrosa energia:

Y em furioso, veloz remolino, y em aérea fantástica danza, que la mente del hombre no alcanza en su rápido curso a seguir, los espectros su ronda empezaron, cual en círculos raudos el viento remolinos de polvo violento y hojas secas agita sin fin. ${ }^{273}$

A coreografia é cada vez mais louca, uma "ronda frenética / que em raudo giro se agita (...) más cada vez se atropella, / más cada vez se arrebata, / y em círculos se desata / violentos más cada vez”. E, no meio dessa vertigem, o casal em um abraço sôfrego realiza suas bodas. Montemar, espremido nos braços lúbricos do horrível esqueleto, sente-se desfalecer: "la flaca, vil materia / comienza a desmayar." Com a confusão do bailado que vem e vai dos mortos a sua volta, a ânsia lhe invade o corpo, o peito aperta, o olhos turvam, "siente sus brazos / lánguidos, débiles", a fronte se inclina e ele morre.

O modelo goethiano aparece ainda em La danse des morts, de Gérard de Nerval, publicado postumamente, em 1855. De novo, temos as batidas da meia-noite e o cemitério: no conto, o narrador passa pelo local nesse exato instante. Ele ouve ruídos provenientes da tumba de um antigo menestrel e, repentinamente, se vê diante de seu espectro - de violão em punho, tocando e declamando. Na obra de Nerval, não são os cadáveres que retornam, mas seus espíritos que, não obstante, estavam nas sepulturas. Uma multidão de espectros sai ao chamado do músico, que evoca aqueles que morreram por amor. Alguns deles são convocados a contar suas histórias: uns foram assassinados (pela amada, por seu esposo ou pai); outros, condenados por crimes de amor, e há ainda aquele que se suicidou. Cada relato é recebido com uma saraivada de palmas, risadas e balbúrdia.

\footnotetext{
${ }^{273}$ ESPRONCEDA, 2014, p. 70-1.
} 
Ao fim, "la blanche troupe flotta en cercle. "274 E, assim que o relógio soou uma hora da madrugada, os espíritos se dispersam, voltando às suas covas.

O mesmo tipo de evento se passa no curto poema La fête des morts, de Auguste Brizeux, publicado pela primeira vez em 1855, em Histoires poétiques. Em uma estrofe de dez versos, o autor refaz a atmosfera das danças contemporâneas: é noite, os sinos dobram; para escapar do lamento dos toques, o narrador caminha para fora da cidade (“Le glas tinte. J'ai fui bien loin dans les vallées / Pour échapper au cri des cloches désolées [...] Au muet firmament chaque étoile est étéinte”). ${ }^{275}$

Esse afastamento da vida urbana é um prenúncio dos acontecimentos fantasiosos que testemunharia e o nevoeiro, "bruillard", que ele encontra na saída prepara essa passagem, sugerindo um estado de confusão ou de incerteza, de entrada em uma atmosfera quase onírica - é de noite, o período em que a gente dorme. Ele pressupõe a entrada nos territórios afastados da vida e próximos da morte, como o cemitério - local que o narrador encontra e é caracterizado pelos salgueiros (que aparecem também na dança de Flaubert) e pelas tílias (presentes na dança de Cazalis). Dos primeiros, ele ouve o choro, das segundas, um murmúrio. O clima outonal, portanto fresco, colabora com a atmosfera fúnebre ("C'est l'automne, / C'est la Fête des Morts lugubre et monotone!”). Esta é a noite em que todos, “en tumulte ont vidé leur cercueil." Diante da cena, ele retorna à cidade onde todos repousam e ainda é escuro. Os sinos dobram outra vez.

O título do poema de Brizeux sugere que os acontecimentos narrados se passam no Dia de Finados, que acontece em meados do outono, comemorado no dia 2 de novembro. $\mathrm{O}$ hábito de se reservar um dia para homenagear os mortos era já comum desde as culturas pagãs. Com a instauração do "dia de Todos os Santos", pelo Papa Gregório III (731-741 dC), no 1o de novembro, gradativamente Finados se vincula a esse feriado, passando a ser celebrado no dia seguinte: “a celebração da festa dos Mortos é bem atestada a partir de cerca de 1030. "276 A cristianização da data fez com que fosse dedicada às orações aos mortos católicos. Na Baixa Idade Média, com a invenção do Purgatório, o "dia dos mortos" se especializa, sendo concebido como o

\footnotetext{
${ }^{274}$ NERVAL, 1855, p. 355.

${ }^{275}$ BRIZEUX, 1860, p. 357. Todas as citações do poema são provenientes dessa referência.

${ }^{276}$ SCHMITT, 1999, p. 194.
} 
momento ideal para se rezar pelas almas que lá se encontram, e para sua entrada rápida no Céu. ${ }^{277}$

Logo, por ser imediatamente anterior a Finados, a noite do dia de Todos os Santos seria também, no imaginário popular, bastante impregnada pelos espíritos dos mortos, sendo possível até mesmo o seu retorno - também uma reminiscência das crenças pagãs. Outras ocasiões do ano se mostrariam oportunas para essa abertura do mundo dos vivos aos falecidos, como o dia anterior ao de Todos os Santos - o 31 de outubro, conhecido como Samhain para os celtas. Essa festividade marcava o fim do verão; nessa passagem para a estação fria acreditava-se que ainda os mortos poderiam transpor a barreira entre os mundo e passar brevemente ao convívio com os vivos.

Tais celebrações a Igreja sempre lutou por eliminar ou dominar. No caso do Samhain, ele é convertido em All Hallows 'Eve, a véspera do dia de Todos os Santos. ${ }^{278}$ Ainda assim, a festa sempre teve matizes confusos, que misturavam a devoção e a homenagem solene aos falecidos com os elementos característicos dos encontros pagãos, como danças, música, bebidas, orgias.

O sincretismo se revela ainda mais desconcertante quando se percebe, na convergência entre as práticas celtas e cristãs e as crenças da Idade Média anglo-saxã, a introdução de ingredientes de difícil rastreamento, como a presença de bruxas e feiticeiras no imaginário desses eventos. Pode-se supor que a manutenção do aspecto festivo e ritualístico se devesse à pessoas ligadas às antigas supertições (incluindo-se, aí, o retorno dos mortos) e que, perante a Igreja, eram hereges.

Como se sabe, em especial a partir do fim da Idade Média, o tema da bruxaria se tornaria uma verdadeira paranóia para o Ocidente. Dentro do repertório sobre o assunto, os sabbats ocupam posição privilegiada, pelo interesse que sempre despertaram.

"Sabá", a partir dos primeiros relatos da Inquisição sobre a existência de seitas heréticas no seio da cristandade (que, em geral, eram fruto da persistência das crenças pagãs), passava a denominar todo encontro ritualístico com o objetivo, supostamente, de profanar Deus e a Igreja. Com a construção da imagem da "feiticeira", e de seu desdobramento mais famoso, a "bruxa", a Inquisição reuniu indelevelmente o sabá e a

\footnotetext{
${ }^{277}$ SIMPSON, Jaqueline. In: HOWARTH e LEAMAN, 2004, p. 174.

${ }^{278}$ GALLERY, Steven. In: HOWARTH e LEAMAN, 2004, p. 174.
} 
bruxaria, tornado-os praticamente sinônimos. A "epidemia de bruxaria", conforme expressão de Michel Vovelle, ${ }^{279}$ começa em 1482, com a publicação do Malleus maleficarum, do dominicano Jacques Sprenger, verdadeiro manual de reconhecimento, perseguição e punição de suas praticantes. Entre 1574 e 1621, o livro é inúmeras vezes reeditado $^{280}$ - não por acaso, coincidindo com os processos inquisitórios, que datam entre os séculos XV e XVII, resultando em uma grande produção de discursos sobre suas participantes ("uma verdadeira obsessão", segundo Franco Cardini, ${ }^{281}$ tanto de persegui-las quanto de cria-las), gerando esteriótipos e sistematizando cada vez mais o imaginário relativo à bruxaria, que se tornava repleto de elementos fantasiosos (os vôos noturnos, o transmorfismo animal, o encontro com o diabo) e práticas consideradas maléficas (a antropofagia, os sacrifícios, o incesto, a zoofilia). As perseguições, com julgamentos longos e sentenças públicas, fizeram aumentar a curiosidade popular pelos eventos que supostamente teriam lugar nas reuniões das acusadas, que a Igreja nominou sabás na tentativa de enfatizar seu caráter não-cristão e, no limite, demoníaco. De acordo com Carlo Ginzburg:

\footnotetext{
Bruxas e feiticeiros reuniam-se à noite, geralmente em lugares solitários, no campo ou na montanha. Às vezes, chegavam voando, depois de ter untado o corpo com unguentos, montando bastões ou cabos de vassouras; em outras ocasiões, apareciam em garupas de animais ou então transformados eles próprios em bichos. Os que vinham pela primeira vez deviam renunciar à fé cristã, profanar os sacramentos e render homenagens ao diabo, presente sob a forma humana ou (mais frequentemente) como animal ou semianimal. Seguiam-se banquetes, danças, orgias sexuais. Antes de voltar pra casa, bruxas e feiticeiras recebiam unguentos maléficos, produzidos com gordura de criança e outros ingredientes.

São esses os elementos fundamentais que se repetem na maior parte das descrições do sabá. ${ }^{282}$
}

Durante dois séculos e meio, o esteriótipo inquisitorial da bruxa e do sabá permaneceu imutável - mesmo que desacreditado e, muitas vezes alvo de chacota (como no caso de um autor elisabetanto, Reginald Scot, que em seu Discoverie of

\footnotetext{
${ }^{279}$ VOVELLE, 1983, p. 285.

${ }^{280}$ Idem, ibidem.

${ }^{281}$ CARDINI, 1982, p. 71.

${ }^{282}$ GINZBURG, 2012, p. 9.
} 
Witchcraft (1584) cita diversas vezes o Malleus Maleficarum e outros manuais para expor o ridículo das descrições ali contidas. Segundo Georges Minois, "os tratados de demonologia, que apresentam os sabás e os atos das feiticeiras sob forma de culto invertido, com uma imaginação delirante e verdadeiramente carnavalesca, são, para os adversários, inesgotáveis fontes humorísticas" ${ }^{283}$ ). O tema finalmente parece ter sido desprezado pelo racionalismo iluminista, que via como barbárie e superstição tanto a crença em bruxas quanto a cruzada contra elas.

Praticamente esquecido no século XVIII, o sabá foi recuperado pelo Romantismo, que, curiosamente, aproximou sua imagem à das danças macabras, misturando seus elementos. A associação entre os sabás e as danças macabras nunca ocorreu na origem, mas, a partir de então, o retorno dos mortos para dançar não era mais visto como uma alegoria, que continha ensinamentos, mas como artimanha do Diabo (na Danse des Morts de Flaubert, como visto, é Satã quem faz os mortos dançarem) que tem na bruxa sua fiel escudeira e agia sob seu intermédio nos encontros sabáticos.

Os autores criaram muitas vezes um novo tipo de dança macabra, um tipo de "dança infernal", na qual participam todos os personagens malditos das fabulações medievais. Seria possível encontrar feiticeiras, demônios, sapos e gatos pretos, festejando e cometendo todo tipo de infâmia junto aos mortos, cadavéricos ou esqueléticos, até então, protagonistas das novas danças contemporâneas - e o caso mais exemplar provavelmente seja A orgia dos duendes, de Bernardo Guimarães, que será analisada mais adiante. Por vezes, a própria Morte anuncia a dança como um sabá, promovendo essa aproximação, como na dança de Ducos du Haron: "elle donnait le signal du sabbat." E mais à frente: "D’heure en heure grandit le sabbat délirant." Na Danse des morts de Anatole France, os vivos são convidados à participar do "sabá" pelos cadáveres-músicos. ("Cet orchestre si doux ne saurait convier / Les vivants au sabbat, et, pour mener la ronde, / Satan aurait vraiment bien tort de l'envier." $)^{284}$

Paul Verlaine também relaciona a noite em que os mortos saem da terra com o sabá: “Un rhythmique sabbat, rhythmique, extrêmement / Rythmique." 285 O poeta entitula seu poema sobre volta dos mortos de Nuit do Walpurgis classique (1867): uma referência tanto à segunda parte do Fausto, de Goethe (em que ocorre um encontro de

\footnotetext{
${ }^{283}$ MINOIS, 2003, P. 305.

${ }^{284}$ FRANCE, 1873, p. 127.

${ }^{285}$ VERLAINE, 1867, p. 53.
} 
bruxas em pleno Walpurgisnacht) quanto à celebração do Walpurgis - ou a noite de vigília para a santa Walpurga, nos países católicos (ela foi canonizada em um primeiro de maio, no século VIII, justamente para coincidir com a festa pagã de Beltaine). Comemorado exatamente seis meses antes de Samhain, na noite de 30 de abril, a festa marca a virada para a estação quente; tanto que a narrativa acontece em um "soir d'été", em meio a um espaço florido de rosas, de vasta gramagem, castanheiras, plantas diversas, fontes jorrando água, estátuas de mármore e de bronze espalhadas pelo passeio - um jardim aristocrático, como aqueles projetados por André Lenôtre, o jardineiro da corte de Luís XIV:

C'est plutôt le sabbat du second Faust que l'autre. Un rhythmique sabbat, rhythmique, extrêmement Rythmique. - Imaginez un jardin de Lenôtre, Correct, ridicule et charmant. ${ }^{286}$

Data também considerada mágica pela tradição pagã, que a comemorava com festas e banquetes (daí sua interpretação sabática pelo cristianismo), o Beltaine promovia o encontro entre vivos e mortos - tanto que, em Verlaine, a ambientação muda depois das batidas da meia-noite: "Minuit sonne, et réveille au fond du parc aulique / Un air mélancolique, un sourd, lent et doux air", preparando a atmosfera para a entrada desses habitantes de outras instâncias. Ao longe, o narrador ouve a música de um intrumento de sopro que lhe enche a alma de medo; essa mesma melodia chama os espectros,"des formes toutes blanches, Diaphanes”, que se confundem umas às outras, em um movimento lânguido, "cheio de um desespero profundo". Em volta dos monumentos, elas dançam em ciranda ("autour des massifs, des bronzes et des marbres / Très lentement dansent en rond."). Diante da cena, o narrador se pergunta se a visão é obra de sua bebedeira (e de seus arrependimentos - seus próprios fantasmas) ou se os espectros de outrém estão lá realmente:

- Ces spectres agités, sont-ce donc la pensée Du poète ivre, ou son regret, ou son remord, Ces spectres agités en tourbe cadencée, Ou bien tout simplement des morts?

(...)

${ }^{286}$ VERLAINE, 1867, p. 53. 
N'importe! ils vont toujours, les fébriles fantômes,

Menant leur ronde vaste et morne et tressautant

Comme dans un rayon de soleil des atomes,

Et s'évaporent à l'instant. ${ }^{287}$

Quando o dia amanhece, as sombras evanescem. Nada mais resta, a não ser o “jardim de Lenôtre".

\section{Os operadores das novas danças: a noite, o cemitério, o encontro dos mortos}

Não obstante suas particularidade, é possível afirmar que a Totentanz de Goethe teria legitimado certos operadores que configurariam o novo modelo das danças macabras do século XIX, distinguindo-se, por meio deles, das obras medievais. Em linhas gerais, eles seriam, principalmente: 1) a noite, como o momento por excelência da volta dos mortos à terra; 2) o cemitério, o local em que os eventos ocorrem, 3) o encontro ou a festa, como o leitmotif do despertar dos mortos e de seu retorno temporário à terra.

Lapso de tempo dedicado ao descanso e ao sonho, a noite é cúmplice da fantasia. Por esse motivo, é o contrário do dia, tempo da ação burguesa, que é o trabalho. Para o homem vitoriano comum, a noite é feita para o descanso restaurador, que prepara para a labuta do dia seguinte. Para a imaginação romântica, não. É quando as sombras dominam que o inexplicável emerge, seja em sonho ou em devaneio. Fim da jornada, momento em que o sol se esconde, a escuridão é sua imagem: ausência de luz, ausência de vida: "La nuit entre majesteusement dans les analogies de la mort”, segundo Edgar Morin $^{288}$. Nos versos da Teogonia de Hesíodo (VIII aC), a Noite é a mãe do Sono e da Morte. "Ela, em muitos medos de outrora, entrava como componente considerável", lembra J. Delumeau, ${ }^{289}$ seja na poesia da Antiguidade, seja na Bíblia. Não é à toa que a volta de Cristo será marcado pelo fim das trevas, pela eterna claridade; Deus é luz, pela doutrina cristã. A falta dela é, por inflexão, território do mal, do Diabo: "era graças à

\footnotetext{
${ }^{287}$ Idem, ibidem, p.55.

${ }^{288}$ MORIN, 1997, 140.

${ }^{289}$ DELUMEAU, 2009, p.139.
} 
sombra que se desenvolvia, acreditava-se a maior parte dos sabás, sendo solidários pecado e escuridão. "290

A noite é a hora da confluência entre a calma, a traquilidade e o repouso com o medo, as assombrações: "tradicionalmente, a obscuridade convém às manifestações sobrenaturais mais inquietantes, as do diabo e dos demônios, as dos fantasmas, explica J-C Schmitt, a noite terrestre, propícia às aparições mais inquietantes, é negra como o pecado; é negra como as trevas do Além povoadas pelas almas privadas da iluminação de Deus. ${ }^{, 291} \mathrm{Na}$ Idade Média, “com raras exceções, os mortos aparecem à noite. Nos sonhos, como convém. Mas também com muita frequência, a homens despertos: aos cair da noite, ao luar, à meia-noite ou ainda na segunda parte da noite. "292

A despeito das superstições medievais, as danças macabras do séculos XV não fazem referência a um período específico para ocorrerem, pelo contrário, a narrativa em geral se passa num tempo-espaço indefinido. As obras iconográficas também não revelam nenhuma preferência, até porque a maioria dela sequer possui um pano de fundo que indique essa inerpretação. Talvez se pudesse mencionar a dança da Basiléia que, por trás dos personagens, representa a cidade e os campos com uma luz que parece diurna, e a dança de H.Holbein na qual os vivos são solicitados em suas atividades cotidianas (de dia, portanto). Ou seja, mesmo nesses exemplos, têm-se a situação oposta à presumida.

Ao contrário da sociabilidade medieval que rejeita a noite e a escuridão (" a noite é suspeita, pactua com os debochados, os ladrões e os assassinos "293), os séculos modernos vão se acostumando a ela e tentam domá-la. Sabe-se que a iluminação públicas nas cidades sempre foi uma preocupação, não apenas como preventivo aos crimes noturnos, mas como tentativa de prolongar as atividades comerciais e os serviços. No século XVIII do Iluminismo, a luz que venceria essa indesejável escuridão era questão central do planejamento urbanístico e comçava a ser possível se manter nas ruas após o pôr-do-sol: ainda que perigosa, a noite saía do breu absoluto. É muito simbólico que o termo "notívago" em francês, noctambule, tenha sido registrado a partir de 1710 , pela contração do latim noctis e ambulare - aquele que perambula de

\footnotetext{
${ }^{290}$ DELUMEAU, 2009, p.147.

${ }^{291}$ SCHMITT, p. 198.

${ }^{292}$ Idem, ibidem.

${ }^{293}$ DELUMEAU, 2009, p. 149.
} 
noite. ${ }^{294}$ Em Paris, às vésperas da Revolução, cerca seis mil postes de iluminação à óleo estavam espalhados pelas áreas de maior circulação (e isso, antes mesmo das reformas haussmannianas); em 1848, eram 2.600 postes à óleo e 8.600 lâmpadas a gás. ${ }^{295}$ Portanto, a experiência do passeio noturno com certa segurança era já possível aos poetas do XIX frequentadores da capital francesa.

Além da ambientação extraordinária que promove, quando transportam a narrativa das danças macabras para a noite, não é de se estranhar que os poemas sejam contados ou tenham por testemunha o personagem que passeia e se depara com os mortos. Esses flanêurs das trevas representam os próprios poetas:

[la nuit] distingue ceux qui dorment de ceux qui veillent, ces derniers, inquiets, parce que passionés, triturent la nuit de leur folles amibitions (...) Celui, ou celle, qui souhaite aller à contre-temps des autres, considère la nuit comme un jour particulier et le jour comme un sommeil à oublier. Ce temps inversé se veut une contestation de l'ordre bourgeois, douillet, hypocrite et répétitif. ${ }^{296}$

Essa inversão, característica dos Românticos, impregna a alma do poeta, que opta por viver no e falar do mundo dos mortos - cujo tempo é a noite. Daí as danças macabras serem feitas com o tom do relato e não da alegoria medieval.

E todas se passam à noite: "Oh! la belle nuit", como diria a dança de Cazalis. Em geral, as ações têm início com o repicar das doze batidas dos sinos das igrejas. Bertrand Utzinger relembra a importância desses objetos na rotina do medievo: "Les cloches ponctuent la vie ordinaire et les phénomènes rares. Elles réveillent l'home, indiquent l'heure du repas et celle du repos. Elles sonnet pour la naissance et la mort, elles tintent pour le feu et la misère. On connaît leur nom et leur chant, on les baptise et on les appelle par leur nom. "297

"Les glas tinte”, é como começa o poema de Brizeux. "Minuit sonne”, na Nuit du Walpurgis Classique, de Verlaine. Na Danse des Morts de Nerval: "je cheminais au

\footnotetext{
${ }^{294}$ PAQUOT, 2000, p. 8.

${ }^{295}$ PAQUOT, 2000, p. 8.

${ }^{296}$ PAQUOT, 2000, p. 9-10.

${ }^{297}$ UTZINGER, 1996, p. 231.
} 
milieu des rêveries et de l'effroi qui vous assaillent à minuit." E na de Cazalis: "La mort à minuit joue un air de danse." Flaubert inicia seu poema em prosa evocando os mortos à meia-noite: “À la danse quand minuit sonne!” Toda a ação do poema de Espronceda acontece no período noturno, e o aparecimento dos mortos, sempre depois da meia-noite (“Era más de media noche”, diz o primeiro verso).

Fonte isolada de claridade, a lua é o único astro a iluminar o encontro dos mortos: "la lune vous éclaire, quel plus beaus lustre?" pergunta o narrador na Danse des Morts de Flaubert; "il fasait un brillant clair de lune" na de Nerval. "La lune d'un soir d'été sur tout cela", na noite de Walpurgis de Verlaine.

A noite, fase inescapável da jornada, é metáfora para a morte: o fim do dia, o fim da vida. É a percepção do mundo como prolongamento do próprio homem, a Natureza como projeção, nela se refletindo a condição humana. $\mathrm{O}$ apodrecimento dos frutos, as flores que murcham, as folhas que secam, o crepúsculo, o frio, remetem à decadência do corpo. "Les fruits tombent, les germes lèvent: c'est l'image de la loi vivante qui régit l'univers", diz Albert Béguin, ${ }^{298}$ tal como no poema de Charles Hubert Millevoye sobre a queda das folhas (“chaque feuille qui tombe, / je vois un présage de mort”). ${ }^{299}$

Em uma carta que Novalis escreve a Schiller, em 1794, lê-se sobre o fim do outono, anunciador do inverno e também da morte: "la féconde maturité à se changer en décomposition, et pour moi la vue de la nature lentement mourante est presque plus riche, plus grande que sa floraison et son éveil au printemps..." ${ }^{300}$. Com o mesmo sentido, na Fête des morts, de Auguste Brizeux, a estação que substitui o verão se relaciona diretamente com os festejos de Finados: "C'est l'automne, / C'est la Fête des Morts lugubre et monotone!",301 $\mathrm{Na}$ dança de Cazalis, "Le vent d'hiver souffle, et la nuit est sombre." Na Danse de Morts, de Flaubert, a gélida noite invernal é a própria Morte que se anuncia: "La nuit, l'hiver, quand la neige tombe lentement comme des larmes blanches du ciel, c'est ma voix qui chante dans l'air et fait gémir les cyprès en passant dans leur feuillage."

A dança dos mortos no século XIX tem, então, hora, a meia-noite, e local, o cemitério - a despeito de suas correlatas medievais, que nunca indicavam de onde saíam

\footnotetext{
${ }^{298}$ BÉGUIN, 1939, p. 120.

${ }^{299}$ In LARMAND, 1910, p. 95.

300 apud BÉGUIN, 1939, p. 37.

${ }^{301}$ In: LARMAND, 1910, p. 127.
} 
e para onde voltavam os mortos. ${ }^{302}$ Mas a necrópole oitocentista já diferia sobremaneira dos antigos e caóticos campos-santos medievais, conjugados às Igrejas e claustros - que recebiam em seu espaço interno as sepulturas da elite aristocrática e clerical - (ou ainda, próximos às relíquias de santos, ad sanctos) e nos quais as fossas comunais ocupavam os espaços principais.

Na Idade Média, o cemitério era um lugar público, um lugar de encontro e de jogo, apesar dos ossos expostos nos ossários e do afloramento de pedaços de cadáveres mal encobertos.(...) A coexistência no mesmo local, no cemitério medieval, dos enterros e das reuniões públicas, das feiras ou comércios, das danças e jogos mal afamados, já indicava que não se devotava aos mortos o mesmo respeito que hoje achamaos lhes ser devido. Vivia-se com eles numa familiaridade que hoje nos parece quase indecente. ${ }^{303}$

Mais parecido com uma praça, o cemitério medieval não era, definitivamente, un "lieu enclos, civilisé et dominé. De jour, il demeure sale, négligé, parcouru de vivants bêtes et gens - et le choses ne changeront pas de sitôt. ${ }^{, 304}$ Mas seu caráter insalubre foi se tornando insuportável com o passar dos séculos e o consequente crescimento das cidades. A superlotação dos terrenos era intolerável ao discurso Iluminista, que associava o amontoado de mortos à uma ameaça iminiente à saúde pública. Na Encyclopédie de Diderot e D'Alembert, lê-se no verbete "Cimetière”: "Lorsqu'un cimetière a été pollu par effusion de sang ou par quelque autre scandale, il faut le réconcilier ${ }^{, 305}$ - os fluidos corporais que contaminam o terreno eram "escandalosos."

O édito real, assinado por Luís XVI na França, em 10 de maio de 1776, interditando as sepulturas dentro das Igrejas e das cidades foi simbólico nesse sentido. Nas décadas de 1770 e 1780, o mesmo ocorre sob Gustavo III na Suécia, Joseph II na Áustria, Catarina II na Rússia, Carlos III na Espanha, todos proibindo os enterros intramuros - o que mostra um movimento generalizado de afastamento das necrópoles, consideradas agora focos de podridão e contágio. A destruição do cemitério de SaintsInnocents, o principal de Paris, de 1785 a 1787 foi também um marco:

\footnotetext{
${ }^{302} \mathrm{Na}$ dança de Holbein já ocorre essa indicação nas primeiras gravuras, que mostram os esqueletos saindo animadamente dos ossuários - imagem replicada em obras influenciadas por ela.

303 ARIÈS, 2003, pp. 181, 204.

${ }^{304}$ VOVELLE, 1983, p. 160.

${ }^{305}$ Encyclopèdie, 1765 , p. 453.
} 
de onde se retiraram mais de dez pés de terra infecta de despojos de cadáveres, onde se abriram quarenta ou cinquenta fossas comuns das quais se exumaram mais de 20.000 cadáveres com seus esquifes, de onde se trasnportaram para as pedreiras, batizadas de catacumbas pelas circunstâncias, mais de 1.000 carroças de ossadas. Imaginemos oito a nove séculos de mortos tirados de uma sepultura que muitos escolheram com devoção em seu último momento (...) ${ }^{306}$

Novos terrenos eram disponibilizados para a realização de enterros extramuros, maiores, mais organizados, distante dos centros e, mais importante, das Igrejas. As administrações locais, seculares, assumem a gestão dos novos cemitérios, completando seu processo de laicização no fim do século XVIII. Os antigos cemitérios intramuros, adjacentes às igrejas, ou ad sanctos, eram então desocupados e destruídos, e os ossos levados à criptas e catacumbas, ou às novas propriedades. Divididas de maneira "racional", essas contavam com um grande espaço designado às valas dos pobres projeto que substitui as antigas fossas comunais - que já não seriam mais enterrados uns sobre os outros, mas uns ao lado dos outros, individualmente. O restante do terreno, financeiramente mais importante, era dividido em lotes que poderiam ser adquiridos em concessão perpétua. ${ }^{307}$ Nesse espaço, era garantido à família o direito de construir em sua propriedade o que desejasse, lápides e monumentos de sua preferência.

Desse processo, emergeriam as grandes necrópoles urbanas que nascem no século XIX e que caracterizam a "era de ouro dos cemitérios", quando os pequenos cemitérios paroquiais são substituídos por um grande cemitério geral, às margens das cidades. São exemplos o Père-Lachaise (1800), o de Montmartre e de Montparnasse (ambos de 1804) em Paris, a Necrópolis de Glasgow (1833), Mount Auburn, em Boston (de 1831, o primeiro de uma série por todos os Estados Unidos ${ }^{308}$ ), All Saints (1831) e Abney Park (1840), em Londres, o Central de Viena (1874).

\footnotetext{
306 ARIÈS, 2003, p. 207.

307 L'innégalité reste toujours dans la mort. Le double du pauvre reste humilié, accablé, lumpenprolétaire de l'au-delà, tandis que le roi a le sort des dieux, et le grand celui des héros. Elle se manifeste toujours dans les villes-nécropoles comme dans nos Père-Lachaise où sont séparés les splendides mausolées des pierres tombales nues, les "gros morts", des petits morts. La maison du mort est reflet de la maison du vivant. La concession à perpétuité dresse une immortalité qui veut s'affirmer éternellement, tandis que la fosse commune recueille ceux qui n'auront dans la mort même pas cet embryon de vie personnelle qu'ils pouvaient dérober de leur vivant. Celui dont la vie individuelle a été ignorée ou niée n'aura pas de tombe: qui n'a pas de propriété n'a pas de survie. Le criminel, le traître, l'impie, le vagabond, n'ont pas plus le droit de survivre que de vivre. MORIN, 1970, p. 155.

${ }^{308} \mathrm{Na}$ Filadelfia em 1836; Rochester, Baltimore e Worcester em 1838; Pittsburgh em 1844, Cincinatti em 1845; Louisville em 1848; Richmond em 1849 e Charleston em 1850. (VOVELLE, 1983, p. 634)
} 
A possibilidade de se erigir monumentos funerários nas campas transforma a imagem da necrópole, a partir de agora repleta de tumbas, capelas funerárias, efígies e estátuas, além de belos arranjos paisagísticos, com árvores e plantas, inaugurando o conceito de cemitério-jardim. Local apropriado para o encontro com os entes queridos enterrados ou com os despojos de personagens ilustres, transformou-se em espaço de lazer e passeio. Inaugurava-se assim, a idéia da visita ao cemitério, onde "moram" os que já se foram. Divididos em quadras, as necrópoles se configuram como versões estilizadas das cidades dos vivos, resumos simbólicos da sociedade, nos quais as hierarquias são separadas pelos terrenos de maior e menor valor e pelas construções mais ou menos exuberantes, que seus habitantes ocupam para o descanso eterno. Le tombeau est une maison, afirma Edgar Morin. ${ }^{309}$ Enterrar os entes queridos e depois seguir assiduamente reencontrando seus despojos era, segundo P. Ariès, uma das consequências do medo da morte desenvolvido no século XIX: ${ }^{310}$ a percepção do fim da vida como uma ruptura, como aniquilação total, se convertia em um apego profundo aos restos mortais do outro - na falta de uma continuidade post-mortem, isso era tudo o que dele restava - e o desejo de prolongar sua presença na terra para além de seu desaparecimento.

Os românticos não ficaram alheios à essa transformação dos cemitérios, tanto visual quanto simbólica, e utilizavam-no como cenário de suas obras, mostrados como portais para a reunião com os que se foram, decorados pelos mais diversos monumentos que os homenageam, além de cobrirem seu corpos putrefatos, seus esqueletos ou mesmo seus espíritos sobre a terra - como na abertura da Comédie de la mort, de Gautier: "Mes vers sont les tombeaux tout brodés de sculptures, / Ils cachent un cadavre, et sous leurs fioritures / Ils pleurent bien souvent en paraissant chanter." Ou ainda, em Bouchers et Tombeaux, quando os esqueletos que saem de suas tumbas, "Dans le marbre, joyeusement / Amours, aegipans et bacchantes / Dansaient autour du monument." Mesmo em um cenário de sonho, os mortos do poema de Espronceda saem da terra, abrindo caminho, quebrando "las losas del pavimiento", como se estivessem sob sepulturas. O narrador da dança de Nerval caminhava diante do cemitério quando vê as tumbas se abrirem ao chamado no menestrel. E no poema de Verlaine, eles "autour des massifs, des bronzes et des marbres / Très lentement dansent en rond."

\footnotetext{
309 Prossegue o autor: En tant que maison du mort, il correspond aussi et surtout à la survie postmortelle du double, qui, de même que le vivant, doit avoir un domicile. MORIN, 1997, p. 139.

${ }^{310}$ ARIÈS, 2003, p. 210.
} 
Local de contemplação e de de passeio, as plantas fazem parte do novo cemitério tanto quanto as lápides. O cipreste aparece no cemitério da Danse des Morts, de Flaubert, árvore muito plantada nos cemitérios urbanos depois da sua reestruturação. Em La fête des morts de Brizeux, os salgueiros e a tílias fazem parte do cenário ("Les saules sont en pleurs, et des pâles tilleuls / Un murmure plaintif s'exhale.”). "Entre les fleurs et les acanthes", os mortos vêm à tona, no Bouchers et Tombeaux, de Gautier. "Imaginez un jardin de Lenôtre”, nos diz Verlaine, "Des châtaigniers; des plants, de fleurs formant la dune", e ainda "des rosiers e des ifs". Na dança de Cazalis, "des gémissements sortent des tilleuls”.

$\mathrm{O}$ terceiro fator de diferenciação entre as danças macabras medievais e as contemporâneas é a motivação da evento. Nas primeiras, prevalece a função didática do encontro entre os mortos e os vivos - ensinar ao público das obras, fossem poéticas ou iconográficas, lições sobre a vida e ensinamentos para uma boa morte. Nas danças do século XIX, o papel pedagógico se perde, em detrimento do clima festivo da reunião de cadáveres. "Ils vont toujours, les fébriles fantômes,/ Menant leur ronde vaste et morne et tressautant", no poema de Verlaine. Mesmo na dança de Nerval, em que os fantasmas só se encontram para trocar histórias, eles "rirent joyeusement en choeur (...) la blanche troupe flotta en cercle". No Estudiante de Salamanca, os mortos aparecem no funeral e no casamento de Félix, dançando frenéticamente um "torpe compás",311, a ponto de contribuírem para a perda de seus sentidos antes de falecer. Todo o poema de Cazalis tem o ritmo da dança dos esqueletos que "vont à travers l'ombre, courant et sautant sous leurs grands linceuls".

${ }^{311}$ ESPRONCEDA, 2014, p. 48. 


\section{Uma variação do tema: a Morte vai ao baile}

Os três operadores aparecem, em maior ou menor grau, nas danças oitocentistas. Contudo, no caso da Danse macabre de Baudelaire, publicada na segunda edição das Fleurs du mal, em 1861, temos uma importante inversão dessa proposta. Apesar do título, o poeta não emula uma dança macabra de nennhum dos dois modelos, oferecendo, por sua vez, uma descrição de uma Morte coquete, que se arruma como uma dama e vai ao baile dos vivos - lá realizando sua fatal coreografia.

Baudelaire dedica o poema ao amigo e escultor Ernest Cristophe. Ele teria se inspirado em uma pequena estatueta em terracota de sua autoria (de 1859), de um esqueleto feminino ricamente vestido. Nos versos do poeta francês, a figura é a personalização da Morte que, mesmo lembrando as características da Morte dos Triunfos (poderosa, segura) é também uma bela e terrível mulher. "Tão orgulhosa quanto uma pessoa viva" de sua postura nobre, mas desenvolta como uma coquete, ela segura com elegância um bouquet de flores, um lenço e suas luvas - tal como na estátua.

Fière, autant qu'un vivant, de sa noble stature,

Avec son gros bouquet, son mouchoir et ses gants,

Elle a la nonchalance et la désinvolture

D'une coquette maigre aux air extravagants. ${ }^{312}$

Trajando "sa robe exagerérée de royale ampleur" que disfarça seus "funèbres appais"; nos pés, punhado de ossos secos, um "soulier pomponné, joli comme un fleur", e, sob o crânio um arranjo de flores, ela chega ao baile causando comoção: "Viton jamais au bal une taille plus mince?", perguntam-se os convivas. Pois o que ela mostra, segundo o poeta, é “l'élégance sans nom de l'humaine armature”.

Há os que não compreendem seus encantos, "amants ivres de chair":

\footnotetext{
${ }^{312}$ BAUDELAIRE, 1861, p. 225.
} 
Pour dire vrai, je crains que ta coquetterie

Ne trouve pas un prix digne de ses efforts

Qui, de ces coeurs mortels entend la raillerie?

Les charmes de l'horreur n'enivrent que les forts!

Qual seria sua intenção? A Morte, penetra imprevista na "Festa da Vida" chega para atrapalhá-la ou para também gozar de seus prazeres?: "Viens-tu troubler, avec ta puisante grimace / La fête de la Vie? (...) Te pousse-t-il, crédule, au sabbat du plaisir?"” Ela passeia por entre os participantes, "inépuisable puîts de sottise et de fautes!", "dançarinos prudentes" que a evitam ou que contempla o "sourire éternel des trentedeux dents" com "amères nausées". A eles, a Morte declara: "malgré l'art des poudres et du rouge / Vou sentez tous la mort!’” E quem são os vivos a quem a Morte se dirige, quem são os comensais do baile que ela invade? Toda a Humanidade, "risible Humanité". Assim, "au chant des violons, aux flammes des bougies”, tem início "le branle universel de la danse macabre."

Essa construção da morte que vai ao baile proposta por Baudelaire já aparece em outro autor que grande influência teve no poeta francês: o americano Edgar Allan Poe. Em The masque of the Red Death, de 1842, Poe coloca em cena uma Morte mascarada e, cabe apontar, também na estátua de E. Cristophe que inspirou Baudelaire, o esqueleto segura uma máscara de rosto feminino. Se a imagem, de fato, representa a Morte que vai ao baile, pode-se pressupor que seria um baile de máscaras e que ela entra despercebida até revelar sua identidade. No entanto, a Morte, no conto de Poe, é uma figura masculina, uma representação pouco usual nos territórios de língua latina. Assim é como ela também aparece nas gravuras da Todtentanz, do alemão Ferdinand Barth, de 1866.

O texto começa recriando as condições de uma epidemia fulminante, aos moldes da peste negra do século XIV - ainda que não haja indicação sobre o espaço-tempo exato no qual se desenrola a história. Os sintomas do bacilo inventado por Poe eram os mesmos daquele que dizimou um terço da população européia no fim da Idade Média mas seu ataque, muito mais feroz: em menos de duas horas, a vítima entrava em óbito:

No pestilence had ever been so fatal, or so hideous. Blood was its Avatar and its seal --the redness and the horror of blood. There were sharp pains, and sudden dizziness, and then profuse bleeding at the 
pores, with dissolution. The scarlet stains upon the body and especially upon the face of the victim, were the pest ban which shut him out from the aid and from the sympathy of his fellow-men. And the whole seizure, progress and termination of the disease, were the incidents of half an hour.

$\mathrm{Na}$ tentativa desesperada de escapar do contágio que assola o território onde vive, o príncipe Próspero encerra-se com sua corte em uma antiga abadia, cujo prédio a ele pertence. O que parece ser de um egoísmo sem análogo era, na verdade bastante comum em tempos de Peste Negra. Sabe-se que os nobres ou a elite urbana retiravam-se dos vilarejos em que um surto epidêmico se aproximava, antes que eles fossem fechados e a população pobre obrigada ao confinamento. Há inúmeros casos em toda a era moderna, ou seja, durante todos os séculos em que a epidemia se manifestou, passando de cidade em cidade e espalhando o terror de uma morte medonha e repugnante por toda a Europa. Eram momentos de desespero extremo: “Um projetor de alta potência era repentinamente apontado para os homens, desmascarando-os sem piedade: muitos pareciam covardes e odiosos", 313 comenta Jean Delumeau em seu estudo sobre a história do medo no Ocidente.

Os ricos, é claro, eram os primeiros a fugir, criando assim a apreensão coletiva. Seu exemplo era imediatamente seguido por toda parcela da população que possuía mínimos recursos para tal. Bocaccio inventou a história de dez jovens que se refugiaram no campo, após deixarem Florença em 1348, no auge do contágio, em seu Decamerão, provavelmente inspirado pelos casos reais. Posteriormente, o dado da fuga da peste volta a aparecer no Diário de um ano da peste (1722), de Daniel Defoe, sobre o ataque da epidemia em Londres, em 1665. Acredita-se que, na ocasião, um quinto da população, cerca de 75 a 100 mil habitantes, tenham perecido. ${ }^{314}$ De acordo com Defoe, 200 mil pessoas deixaram a capital, a começar pela elite:

\footnotetext{
${ }^{313}$ DELUMEAU, 2009, p. 194.

314 Desse ciclo endêmico, que atacou desde o norte da Europa, passando por Flandres, Normandia, chegando à Espanha até o mediterrâneo e, depois, à Europa do Leste, Vovelle contabiliza as perdas de algumas outras cidades: Reste, incontestablement, que la peste, dans la première moitie du siècle demeure un fleau dévastateur qui fait des coupes sombres dans les populations urbaines: capable de réduire à rien ou presque la population d'une petite ville comme Digne en 1626, fauchant en 1630 moitié ou plus de la population dans une demi-douzaine de villes italiennes - Parme, Crema, Vérone, Crémone, Mantoue, la plus touchée avec près de $70 \%$ de morts. En Angleterre, ou plus précisément encore en Espagne, on a tenté d'apprécier le bilan global de ces pestes du XVIIe siècle: entre 1596 et 1685, elles auraient ainsi coûté un million deux cent cinquante mille vies à l'Espagne (...) (VOVELLE, 1983, p. 259)
} 
(...) the richer sort of people, especially the nobility and gentry, from the west part of the city, with their families and servants, in an unusual manner (...) nothing was to be seen but waggons and carts, with goods, women, servants, children, etc, coaches filled with people of the better sort, and horsemen attending them, all hurrying away (...) This was a very terrible and melancholy thing to see, and as it was a sight wich I could not but look on from morning to night, for indeed there was nothing else of moment to be seen, it filled me with very serious thoughts of the misery that was coming upon the city, and the unhappy condition of those that would be left in it. ${ }^{315}$

No primeiro capítulo, discutiu-se de que maneira a historiografia da morte sugere que uma das causas para o surgimento do macabro tenham sido justamente as disposições mentais a respeito da morte após a chegada do flagelo em meados do século XIV.

Os artistas quiseram reconstruir - sem dúvida para livrar-se dele e neutralizá-lo - o horror criado pelo acúmulo de cadáveres e pela insustentável promiscuidade dos vivos e dos mortos. Corpos esparsos nas ruas e que apodrecem antes que sejam levados, carroças ou barcas sobrecarregadas que rompem sob o peso, cadáveres puxados com ganchos ou atados à cauda de um cavalo, doentes e mortos tão esprimidos que não se pode dar um passo sem caminhar por cima $(\ldots)^{316}$

são algumas das imagens que inevitavelmente passavam a fazer parte do imaginário da morte macabra nos séculos seguintes, nos locais em que a Peste devastava periodicamente.

E era essa imagem que aparecia nas obras de artes que se sucederam aos seus ataques, como $O$ triunfo da morte, de Brughel, de 1562. O espetáculo medonho de cadáveres amalgamados e doentes em súplica também se vê na Piazza del mercatello em Nápoles de Domenico Gargiulo, de 1656. Ele aparece ainda na escultura em cera Pestilenza, de Gaetano Zumbo (1691-1695), em que corpos agonizantes e mortos de velhos, adultos e bebês estão emaranhados e contorcidos, em tons de amarelos e verdes que acusam estágios pré e post mortem diversos. Na Peste em Atenas, de Nicolas Poussin, que emula a grande contaminação na cidade grega no século V a.C., mas que

\footnotetext{
${ }^{315}$ DEFOE, 19-?, p. 55.

${ }^{316}$ DELUMEAU, 2009, p. 193.
} 
foi feita após o surto de 1630 em Milão, o mau cheiro liberado pelos moribundos e pelos defuntos desfigura a feição daqueles que se aproximam. Esse repertório iconográfico da mortandade generalizada causada pelo detestável flagelo alcança o final dos setecentos, como em $O$ hospital dos pestíferos, de Goya, de 1800.

Seria legítima, portanto, a atitude de Próspero, diante de um cenário assim abominável? A Peste era um fator de profunda desestabilização social e a fuga, justificada. Mas Poe parece contrapor o ato desesperado do princípe à sua conduta depois de salvo: se escapar era necessário, viver em luxo era condenável. Os seis meses de reclusão do anfitrião e de seus convidados se passam no mais absoluto conforto, a ponto de começarem a se entediar. É nessa altura, “quando a peste grassava mais furiosamente lá fora”, que Próspero oferece um magnificente baile de máscaras, cujos preparativos são descritos no conto como "um espetáculo voluptuoso". Aqui, Poe deixa claro que o seu nobre incorre em uma série de erros. Primeiro, ao tentar escapar da morte. Segundo, ao virar as costas aos seus vassalos, elegendo apenas seus pares para o isolamento. Em terceiro, ao promover uma masquerade.

Camuflada em meio à multidão de mascarados, a Morte surge à festa do príncipe, no instante exato em que soam, do grande relógio de ébano no centro do salão, as doze badaladas da meia-noite. Portando também ela uma máscara (ou seria seu rosto, a maneira como escolheu se apresentar na ocasião? A dúvida permanecia entre todos: "The mask which concealed the visage was made so nearly to resemble the countenance of a stiffened corpse that the closest scrutiny must have had difficulty in detecting the cheat.") que imitava os sinais escarlates dos bulbos que deformavam os rostos dos atingidos pela morte rubra, a Morte, perambula pelos salões temáticos da festa, caminha calmamente por todos os aposentos, atraindo os olhares e incitando exclamações. No poema de Gautier, Bouchers et Tombeaux, o narrador se refere ao esqueleto que representa a morte como "masque sans joues / Comédien que le ver mord" máscara é também o instrumento do ator, que finge, que se disfarça e engana. Quando sua identidade é, finalmente revelada, a todos surpreende: "He had come like a thief in the night. And one by one dropped the revellers in the blood-bedewed halls of their revel, and died each in the despairing posture of his fall."

${ }^{317}$ GAUTIER, 1858, p. 227. 
A máscara possui um vínculo quase universal, segundo Carlo Ginzburg, com a morte. Provém dos mais antigos povos o hábito de cobrir o rosto dos cadáveres; daí a origem da máscara mortuária que, além de proteger um rosto possivelmente deformado pelo rigor mortis pudesse ainda rememorar o semblante da pessoa. Tão antigo quanto este uso é o de se esconder a fisionomia em uma cerimônia ou, como é de praxe, em uma festividade, como o Carnaval. Esse momento em que se coloca o mundo às avessas, em que a ordem social é modificada, invertida, parece ideal para o retorno dos mortos ou, no limite, um convite à própria Morte. 


\title{
O Carnaval e a Morte
}

\author{
- ... vejo a morte, \\ Ai vem lazarenta e desdentada... \\ Que noiva!... E devo então dormir com ela?... \\ Se ela ao menos dormisse mascarada! - \\ Álvares de Azevedo. O poeta moribundo. ca 1853.
}

Un bal en carnaval, c'est une fête aux fantômes.

Victor Hugo. Promontorium Somnii. 1864.

$\mathrm{Na}$ cidade suiça da Basiléia, duas danças macabras foram pintadas na década de 1440. Uma, na parede do claustro de um convento de monjas dominicanas. Outra, maior e mais elaborada, também em um convento dominicano, esse, masculino. Nenhuma resistiu ao século XIX e à sua ânsia racionalista por apagar os sinistros rastros da cristandade medieval, mas diversos registros e cópias foram deixados no decorrer dos quatrocentos anos em que elas existiram. Nesse período, muitos artistas se sentiram profundamente tocados pelas imagens, em especial pelo segundo exemplar, mais impressionante. Um deles foi Hans Holbein. Diz-se que, após seu contato com a obra, motivou-se a desenvolver as suas próprias interpretações do tema. ${ }^{318} \mathrm{E}$ foi um absoluto sucesso, pois a "dança de Holbein" (1538) repercutiu tanto ou mais que as danças da Basiléia ou de outros lugares.

Feitas após a famosa dança do cemitério de Saints-Innocents, é bastante provável que o autor, ou autores, de ambas tenham sido estimulados pela novidade inaugurada pela tão comentada obra parisiense - e também pela avassaladora passagem da Peste Negra pela Suiça em 1439. Mas há ainda uma outra hipótese.

No ano de 1838, Louis Veuillot, jornalista francês e católico fervoroso, sai em peregrinação. Com o intuito de ver de perto comunidades rurais isoladas que ainda viviam um cristianismo, supostamente, mais próximo do antigo, mais puro e menos contamidado pela vida urbana e capitalista, se embrenha pelo interior da Suiça,

\footnotetext{
${ }^{318}$ INFANTES, 1997, p. 172.
} 
percorrendo uma série de pequenas vilas. Passando pela Basiléia, visita a biblioteca municipal, onde estão expostas obras de Holbein, "ce gros Holbein, génie rude et brutal", que, segundo ele:

aimait à peindre les cadavres, ou tout au moins les vivants qui s'en approchaient le plus; son crayon austère trace de préférence de maigres profils de vieillards et de savants, qui semblent occupés à supputer le peu d'instants qu'ils ont encore à passer ici-bas; il donne au vêtement une tournure de linceul, la figure est enfermée dans le cadre noir comme dans um tombeau. ${ }^{319}$

Da leitura de Veuillot, supõe-se que Holbein era obcecado pela morte, mas que esse não era um sentimento excusivo do mestre. Toda a Idade Média, segundo o jornalista, o compartilhava e "pensait bravement à la mort." Movido pelo assunto, Veuillot fez uma descrição fabulosa das festas de Carnaval na Basiléia medieval, que incluía essa fixação dos tempos de outrora: "Chaque année, au carnaval, des masques représentant la mort parcouraient la ville em dansant. Ils avaient le droit de saisir tous ceux qu'ils rencontraient, et de les forcer, quels qu'ils fussent, à danser avec eux. "320

É de se imaginar o susto dos transeuntes e as situações desconfortáveis resultantes dessas investidas: "La bizarrerie de ces captures, l'effroi, la mauvaise humeur, la résistance ou la résignation de ceux qui se trouvaient ainsi arrêtés sans s'y attendre, divertissaient les curieux et inspiraient les peintres. "321 Essas cenas, segundo Veuillot, seria tão fortes que teriam inspirado pintores que, a partir delas, começaram a representar a morte em forma humana, fazendo algazarra enquanto perseguia e levava as pessoas consigo à força: "Puis, comme cette danse symbolique parassait renfermer une haute leçon de morale, on imagina d'em composer de grandes peitures qui couvraient ou la façade d'um édifice, ou les vastes murs d'um cloître." O clero teria rapidamente aprovado esse tipo de composição pelo seu profundo valor pedagógico e consentiu em ceder áreas murais de seus prédios para sua confecção, que, em geral, tinham a seguinte estrutura:

\footnotetext{
${ }^{319}$ VEIULLOT, 1845 , p. 386.

${ }^{320}$ VEIULLOT, 1845 , p. 386.

${ }^{321}$ VEIULLOT, 1845, p. 386.
} 
les deux premières figures que l'artiste peignait étaient ordinairement celle du pape et celle de l'empereur; l'um avec as tiare, l'autre avec son sceptre, suivaient de force ou d egré l'inflexible mort. Après eux venait la foule des humains: princes, magistrats, évêques, moines, artisans, les gentilshommes pleins de force et les pauvres perclus, le vieillard à qui l'infatigable danseuse prenait son or, l'enfant à qui elle prenait ses jouets, la jeune mère qu'elle arrachait à as toile imparfaite et qui laissait tomber son pinceau. ${ }^{322}$

Embaixo de cada figura assim desenhada, "ou terrible, ou grotesque”, escreviase uma estrofe de quatro versos, que tinha sempre o mesmo sentido: "Il faut mourir". Mas o jornalista faz uma ressalva: a morte naquele tempo " $n$ 'était pas le néant" e, por isso, caso se vivesse correta e honestamente, não era necessário temê-la.

Nenhum documento sustenta a descrição apresentada por Veuillot. Aparentemente, ele narrou o que sabia, o que escutou, o que leu. De acordo com sua abordagem, portanto, os festejos do Carnaval medieval deram origem às danças macabras - as da Basiléia teriam sido pintadas por causa dessas comemorações locais, servindo posteriormente de referência para o jovem Holbein, afetado por todas essas imagens que não esqueceu jamais.

Ainda que o relato de Veuillot seja um tanto duvidoso, não apenas pela falta de dados mais concretos, mas porque diverge das teorias mais sólidas sobre o surgimento das danças macabras, é inegável que ele representa a idéia de uma estreita relação concebida entre elas e o Carnaval - ou, no limite, entre a morte e o Carnaval. Ora, a festa carnavalesca é, justamente, o espaço-tempo da inversão simbólica - e os temas macabros são impregnado de inversão. Mortos que retornam à terra e conversam, dançam, riem, se divertem - uma transgressão impossível na realidade tangível.

\section{Festividades carnavalescas: inversão e excesso}

Desde suas origens, o Carnaval é momento em que os contrários se exacerbam e os ânimos se excedem. E, ainda que seja possível remontar à Antiguidade em busca de

\footnotetext{
${ }^{322}$ VEIULLOT, 1845, p. 387.
} 
seus elementos formadores, foi na Idade Média que o fenômeno adquiriu a forma com a qual se estabeleceu no mundo ocidental. Sem se relacionar diretamente com nenhum fato da história cristã ou de algum santo em particular, o período carnavalesco sugere uma espécie de amálgama de uma série de festas pagãs, principalmente ligadas aos cultos da fertilidade e à sucessão dos ciclos agrícolas. Ou ainda, reminiscências de celebrações romanas como as bacanais, lupercais e, especialmente as saturnais, que marcavam as passagens do tempo circular e da natureza.

O cristianismo, religião linear e escatológica teria assumido o tempo do Carnaval como um tipo de "acordo de tolerância" em que, em aceitando em sua agenda uma festa permissiva e de desbunde, poderia impor em seguida a grande Quaresma, um tempo de abstinência e preparação espiritual para um de seus eventos fundadores, a Páscoa. A Igreja, assim, adaptava-se aos hábitos seculares da população rural os quais, não conseguindo erradicar mesmo após a consolidação de seus dogmas, incorporava ao seu calendário. ${ }^{323}$ Sua etimologia confirma e assinala os últimos dias antes da carestia, em que ainda é permitido comer carne (carne vale), ${ }^{324}$ antes dos jejuns, das privações e da severidade. São os últimos momentos de liberdade e de libido: "uma festa da abundância durante a qual os homens, para comer, beber e divertir-se, não se preocupavam com os interditos", afirma Jacques Heers. ${ }^{325}$

Apesar de já ser presente no cotidiano do medievo há muito, o Carnaval, propriamente dito, só foi oficializado pela Igreja no século XV, com o papa Paulo II. ${ }^{326}$ Mas, além dele, ou seja, além dos três dias imediatamente anteriores a Quarta-feira de Cinzas (e, em muitos casos, estendendo-se à quinta-feira anterior, conhecida como "Quinta-feira Gorda"), outros eventos marcavam os chamados "festejos carnavalescos". Estas festas, que eram genericamente denominadas de "festas dos loucos" ${ }^{327}$, incluíam a

\footnotetext{
${ }^{323}$ Em 1091, o Concílio de Benevento instaura a solenidade de Quarta-Feira de Cinzas para fixar um limite aos desregramentos carnavalescos cuja impiedade recaía largamente sobre a Quaresma. (MINOIS, 2003, p. 184)

${ }^{324}$ HEERS, 1987, p. 169.

A palavra viria do baixo latim carnelevamen, que significaria "adeus à carne”, numa alusão à terçafeira gorda, o último dia do calendário cristão em que é permitido comer carne. (SEBE, 1986, p. 31.) Para uma etimologia extensa e aprofundada da palavra Carnaval, ver capítulo II de Caro Baroja, Escarceo Linguistico: "Carnaval”, “Carnal”, “Carnestolendas”, “Antruejo”. (BAROJA, 1965, p. 30-49)

${ }^{325}$ HEERS, 1987, p. 169 .

${ }^{326}$ SEBE, 1986, p. 25.

${ }^{327}$ Recebiam esse nome principalmente pelas extravagâncias que se cometiam sob seu pretexto. Elegiase um falso rei entre o povo, que reinaria incontestavelmente até o fim dos festejos. Todas suas vontades seriam atendidas, por mais absurdas que fossem. Às vezes eram também escolhidos outros membros do alto escalão da corte, para acompanharem-no na interpretação e na bufonaria - como uma rainha, um
} 
"festa dos Inocentes"328 e a "festa do asno",329, por exemplo, entre outras (a cena inicial d'O corcunda de Notre Dame, que se passa em 1482, é justamente uma festa dos loucos que acontece por ocasião do dia de Reis, em Paris, em 6 de janeiro ${ }^{330}$ ). Conjunto de manifestações da cultura popular, aconteciam nos três meses que separavam o Natal da Páscoa, e eram recorrentes por toda a cristandade, especialmente nas regiões da Itália, da Espanha, ${ }^{331}$ da Alemanha, na França do norte e na Inglaterra. ${ }^{332}$

Espetáculos ritualísticos, "os festejos do carnaval, com todos os atos e ritos cômicos que a eles se ligam, ocupavam um lugar muito importante na vida do homem medieval." 333 Ocasiões de riso coletivo e de tomada do espaço público pelo povo, eram os momentos da confraternização popular organizada, em que se parodiava a própria vida, ${ }^{334}$ invertendo-a, fazendo-a melhor e mais divertida por um lapso de tempo (como o retorno à idade de ouro que a tradição das saturnais romanas tentavam encarnar). Era a tentativa de transformar a dura rotina diária em horas de puro prazer. ${ }^{335}$ Contrapunham-

papa, um abade, etc. Esses representavam seu papel de maneira cômica, vestindo fantasias que imitavam os trajes verdadeiros. Liam discursos, acendiam incensos mal-cheirosos, cantavam hinos indecentes. $L a$ Fête des Fous était généralement dans toute la chrétienté au moyen âge, mais elle ne fut nulle part célébrée avec autant de ferveur qu'en France. Elas aconteciam desde os primeiros anos da Idade Média, sendo motivo de debates desde os concílios de Orleans, em 533 e de Auxerre em 585, até o concílio de Paris, em 1212, que finalmente defendia sua celebração. No entanto, dès le commencement du quinzième siècle, l'Église de France s'était appliquée a faire la guerre aux scandalesque cette fête avait introduit avec elle dans la pratique du culte, sinon dans le dogme religieux. (LACROIX, 1818, Fête des fous, s/p). Em 1444, a Universidade de Paris condena a festa devido a seus incontroláveis desregramentos. (HEERS, 1987, p 138).

${ }^{328}$ Celebrada por ocasião do dia do massacre dos Inocentes, 28 de dezembro, em memória às crianças mortas por ordem de Herodes - história contada no Evangelho de Mateus. Elegia-se aí também um rei dos Inocentes, um papa, um bispo, etc. As crianças da região participavam ativamente dos jogos e das encenações. Segundo Jacques Heers, um outro tema da festa dos Inocentes, relacionado às crianças, era a lembrança da infância de Cristo (1987, p. 85).

${ }^{329}$ A festa homenageia os burros pertencentes à história de Cristo, seja aquele que o velava e aquecia no estábulo onde ele nasceu, seja aquele que carregou Maria e seu bebê na fuga para o Egito ou ainda aquele que montava em sua entrada em Jerusalém no dia de ramos. Ele é o companheiro fiel da Sagrada Família e, simbolicamente, mostrava como o homem tinha que agir perante Jesus (com humildade, servidão). Emulando um ritual litúrgico todo voltado para o animal, celebrava-se uma "missa do asno", em que se imitava o seu relinchar constantemente em substituição ao "amén" católico, cantava-se e homenageava-se um burro todo paramentado colocado no interior da igreja ou da catedral, como um clérigo. A festa prosseguia após a cerimônia.

${ }^{330}$ HUGO, 2013, p. 24.

331 como comprova o elucidativo estudo de Caro Baroja sobre as festas carnavalescas espanholas. (BAROJA, 1965)

332 HEERS, 1987, p 135.

${ }^{333}$ BAKHTIN, 1987, p. 4.

${ }^{334}$ MINOIS, 2003, p. 156.

335 Sem, por isso, se configurarem como uma espécie de revolta. Jacques Heers lembra que, apesar de denotarem um melhoramento da vida quando essa se encontrava às avessas (mais alegre, mais abundante), as festas carnavalescas não semeavam nenhum tipo de revolução e, até por esse motivo, eram bem toleradas: os governos não tinham dúvidas em tolerar as piadas grosseiras que por algumas horas punham em causa a sua dignidade e escarneciam do seu comportamento e da sua posição social; não passava de um dia desagradável, de alguns momentos que era preciso viver... Farsas tão exageradas, na 
se inclusive, às solenidades oficiais, cujo tom sério servia para consagrar a estabilidade e fortalecer a ordem, homenageando um evento ou personagem heróico do passado, para que fossem rememorados no presente seus triunfos. ${ }^{336}$ Nas festas dos loucos, exaltava-se, ao contrário, o elo fraco da sociedade: a criança, o pobre (na figura do burro, que é o animal trabalhador), o demente (o "folião" ${ }^{337}$ ). ${ }^{338}$

Nesses momentos que precediam a longa carestia, as festividades carnavalescas ganharam o cunho de períodos de exceção. Não eram dias comuns, eram dias de suspensão da normalidade. O que geralmentre seria proibido, ali se tornava a lei: travestir-se (especialmente trocando os gêneros masculino e feminino, ${ }^{339}$ mas também adotando uma nova classe social ou ofício), mascarar-se (mostrar-se como alguém que não se é), dançar e pular (em contraste com a forma séria como se caminhava ou se agia regularmente). Além disso, "eram ocasiões especiais em que as pessoas paravam de trabalhar, e comiam, bebiam e consumiam tudo o que tinham. Em oposição ao cotidiano, era uma época de desperdício justamente porque o cotidiano era uma época de cuidadosa economia. "340 Fuga provisória da vida ordinária, configuravam uma certa

verdade, não constituíam grande ameaça. (1987, p. 1986) Eram apenas um desafogo consentido pelos articuladores do funcionamento da vida, segundo José Carlos Sebe. (1986, p. 29).

Roberto Damatta reforça essa ideia ao comentar as organizações que empreenderam o carnaval brasileiro durante muitas décadas, todas baseadas na coletividade popular (como os blocos, os cordões e as escolas de samba) - nesse sentido, uma continuidades das corporações que organizavam o carnaval medieval - e que, apesar de terem um sistema de extrema complexidade, eram frágeis e sazonais, surgindo com vigor apenas na época da festa. Em outras palavras, trata-se do povo que pouco se organiza espontaneamente para reclamar ou reivindicar, organizado para brincar. (DAMATTA, 1997, p. 69) Isso porque o Carnaval por ser vigorosamente contrário ao mundo cotidiano, e sendo dele uma imagem invertida, apenas reforça esse mundo, confirmando-o. (Ibidem, p. 88)

${ }^{336}$ O tom sério exclusivo caracteriza a cultura medieval oficial (...) era a única forma que permitia expressar a verdade, o bem, e de maneira geral tudo o que era importante, considerável. $O$ medo, a veneração, a docilidade, etc., constituíam por sua vez os tons e os matizes dessa seriedade. (BAKHTIN, 1987 , p. 8 e 63 )

337 A ênfase na "carnalidade" prevista pelo festejo carnavalesco relaciona-se diretamente com a loucura, segundo Caro Baroja, pois ambas pressupõem o declínio da racionalidade: La “carnalidad”implica, pues, no sólo realizar actos opuestos al espíritu cristiano, sino también actos irracionales o, mejor, si se quiere, locos. (BAROJA, 1965, p. 51)

338 Essa característica fundamental da festa carnavalesca se mantém ainda nos eventos da contemporaneidade. Ao falar sobre o carnaval brasileiro, Roberto Damatta atenta para o fato de ser um "rito sem dono", festa que é de todos justamente por que nao pertence a ninguém ou a nenhuma autoridade específica. Uma festa sem dono é primordialmente uma festa dos destituídos e dos dominados. Porque no mundo cotidiano eles nada possuem, somente eles podem ser o centro de uma festividade inevertidade e paradoxal, que não tem programa, lei e donos, mas que pode ser possuída pelos que nada têm. (DAMATTA, 1997, p. 122)

${ }^{339}$ La más clásica inversión propia del Carnaval es la del hombre que se disfraza de mujer y de la mujer que se viste de hombre. (BAROJA, 1965, p. 98)

${ }^{340}$ MINOIS, 2003, p. 202

E Caro Baroja, citando Juan de Zabaleta, complementa, afirmando que o jejum da Quaresma era, às vezes, necessário, após os abusos cometidos: Para Carnaval no había freno...; después, los que 
desarticulação momentânea de um rigoroso e sisudo sistema de regras do Estado feudal e da Igreja (ainda que tolerada por ambos), pressupondo inclusive um grande relaxamento moral. "Ao contrário da festa oficial, o carnaval era o triunfo de uma espécie de liberação temporária da verdade dominante e do regime vigente, de abolição provisória de todas as relações hierárquicas, privilégios, regras e tabus. "341

As festas carnavalescas ocorriam não apenas sob a égide da inversão, mas igualmente do excesso. ${ }^{342}$ Como fenômenos populares, eram a materialização da contestação irreverente, contrariando a ordem das coisas, expondo a relativização da verdade e do status quo. "El Carnaval es época de alegría”, afirma Caro Baroja, ${ }^{343} \mathrm{e}$, através do riso, ridicularizavam-se as formas consolidadas do poder, celebrando a mudança ainda que temporária e excepcional. Um dos seus objetivos é, justamente, permitir, esporadicamente, tudo o que era interdito pela sociedade: a obscenidade, a escatologia, a embriaguez, a lubricidade. Mais do que celebrar a vida - nesse que é o tempo da fecundação (da terra e das mulheres, se levarmos em consideração seu significado primordial antigo) -. o que o carnaval, em seu sentido lato, celebra é a abundância: da comida, da bebida (ou seja, do espírito dionísiaco/báquico), do prazer (do júbilo, da "carne").

Paul Lacroix nos conta, em linhas gerais, como era um evento carnavalesco na passagem da Antiguidade para a Idade Média. O importante é notar como seu sentido de inversão e muitas das práticas se mantiveram ao longo dos séculos.

Segundo o autor, ${ }^{344}$ os trabalhos administrativos e burocráticos eram suspensos no período ("tant que durait cette fête, les affaires publiques et particulières restaient

ayunaban más lo hacían por imposición del própio estómago que por devoción o piedad. (BAROJA, 1965, p. 101)

${ }^{341}$ BAKHTIN, 1987, p. 8

342 "lo que imperaba era una violencia establecida, un desenfreno de hechos y de palabras que se ajustaba a formas especificas; así la inversión del orden normal de las cosas tenía un papel primordial en la fiesta."'(BAROJA, 1965, p. 50)

${ }^{343} \mathrm{O}$ autor enfatiza essa proposição relativizando a ideia de que o Carnaval era apenas uma desculpa para o chiste pesado ou para grosserias e brincadeiras obscenas. Todas essas práticas também ocorriam mas, aparte eso, o al lado de esto, el Carnaval permitia grandes liberdades . (BAROJA, 1965, p. 91)

${ }^{344}$ Esse processo desenvolveu-se de forma especial e em épocas diversas nos diferentes países, e mesmo nas diferentes cidades. Foi primeiro na Itália, e especialmente em Roma, que ele se realizou da maneira mais distinta, mais clássica, poder-se-ia dizer (assim como nas outras cidades italianas, embora de maneira menos distinta, em seguida na França, em Paris, na Alemanha em Nuremberg e em Colônia, da maneira mais ou menos clássica (mas mais tarde). Na Rússia, as coisas foram diferentes: as diversas formas de folguedos populares, tanto os gerais como os locais (Terça-feira Gorda, Dia dos Santos, Páscoa, feiras, etc.) permaneceram fragmentadas e não deram origem a uma forma preponderante, análoga ao Carnaval da Europa Ocidental. (BAKHTIN, 1987, p 190) Cabe lembrar ainda que, apesar das 
suspendues"), o único compromisso era com os prazeres do corpo - festejar e comer ("on ne songeait qu'au plaisir; ce n'étaient que collations, danses, concerts, mascarades; on ne quittait presque pas la table"); elegiam-se os "reis da festa", entre o povo, quando os pobres viviam seus dias de mandatários ("on y fasait des rois $d u$ festin; on y installait les esclaves à la place de leurs maîtres") e a liberalidade era generalizada ("on se permettait de tout dire et de tout faire, comme sous le règne de Saturne, au bom temps de l'âge d'or"). ${ }^{345}$

\section{A carnavalização}

O conjunto de elementos postos em prática nessas festividades caracterizaria uma poética - uma linguagem e uma visão do mundo - também baseadas na inversão e no excesso, que se manifestaria não apenas no espaço público da festa popular, como também em uma produção literária e iconográfica. Essa transposição recebeu o nome de carnavalização. O termo, desenvolvido por Mikhail Bakhtin, a partir da leitura dos textos de François Rabelais e de sua análise da cultura popular da Idade Média e do Renascimento, pode ser uma chave de leitura possível às danças macabras, e do macabro em geral. Em primeiro lugar, e principalmente, porque o retorno dos mortos pode ser considerado o avesso da normalidade.

Em segundo porque a dança macabra derruba as hierarquias, fazendo com que os vivos de qualquer estrato social caminhem lado a lado e de mãos dadas com qualquer outro personagem (também vivo ou morto; rico ou pobre; etc). Destacando, assim, a função niveladora da morte, ela expõe a fragilidade e a relatividade dos poderes, celebrando a igualdade na morte apesar das desigualdades na vida. Ao contrário dos eventos oficiais do regime feudal, em que as hierarquias eram marcadas e expostas, na carnavalização "todos eram iguais e reinava uma forma especial de contato livre e familiar entre indivíduos normalmente separados na vida cotidiana pelas barreiras intransponíveis da sua condição, sua fortuna, seu emprego, idade e situação

festas rurais com características carnavalescas, segundo Georges Minois, o Carnaval é um fato urbano, particularmente desenvolvido nas regiões das cidades importantes, onde as associações e as corporações assumem a organização dos divertimentos. (2003, p. 164).

${ }^{345}$ LACROIX, 1848, La fête des fous (s/p.). 
familiar ${ }^{, 346}$ - esse contato livre e familiar era vivido intensamente e constituía uma parte essencial da visão carnavalesca de mundo. Além do mais, o espectador da cena macabra não se retira do que vê, ele se inclui, se identifica com os personagens, tanto com os vivos quanto com os cadáveres - o jogo carnavalesco requer essa participação, esse sentimento de pertencimento à humanidade, a uma unidade histórica. Na literatura, o diálogo entre vivos e mortos também seria uma característica da carnavalização, "que inter-relaciona dialogalmente aspectos contrários/opostos" e que "se dá pela sátira, ou seja, por um modo de dizer que contesta e ridiculariza costumes, instituições e ideias com ironia e mordacidade., 347

Por último, a dança macabra possui o sentido de carnavalização pois reproduz uma "representação carnavalesca do corpo", que Bakhtin inclui naquilo que ele chama de "realismo grotesco". Conforme definiu o escritor russo, o "grotesco" designa o tipo de “imagens ambivalentes e contraditórias que parecem disformes, monstruosas $e$ horrendas, se consideradas do ponto de vista da estética clássica, da cultura cômica popular em todas as suas manifestações ${ }^{\text {"348 }}$. Convém lembrar que a questão do grotesco enquanto categoria estética ocupou lugar importante entre os românticos, tendo sido debatido por Walter Scott e Victor Hugo, por exemplo. Esse, no prefácio ao Cromwell, estabelece que o grotesco se configuraria como o pólo oposto ao sublime: o primeiro, germe da comédia, submete aquele que o experimenta a um rebaixamento de sua condição humana (podendo levar ao riso, ao desconforto ou à angústia), enquanto que a experiência do sublime resulta em elevação, transcendência. ${ }^{349}$

Assim, em relação ao corpo humano, o grotesco enfatiza a deformação e o exagero (no sentido caricatural) e direciona a atenção ao baixo corporal (" $O$ traço marcante do realismo grotesco é o rebaixamento",350). Na linguagem carnavalesca, o corpo grotesco é aquele aberto ao mundo, com seus oríficios expostos e em destaque, com suas excrescências e mucos, que satisfaz constantemente suas necessidades naturais, sem pudores ou impedimentos. Cabe lembrar que, para Julia Kristeva, o ato de defecar (devolver ao exterior o que se ingeriu dele, pela comida), ao mesmo tempo que necessário à vida, simboliza uma perda que é de si mesmo, de algo que o próprio

\footnotetext{
${ }^{346}$ BAKHTIN, 1987, p. 9.

${ }^{347}$ SCHAEFER, 2011, p. 200.

${ }^{348}$ BAKHTIN, 1987, p. 22 a 27.

${ }^{349}$ HUGO, 1988. Ver mais sobre a definição de "sublime" no Capítulo 2.

${ }^{350}$ BAKHTIN, 1987, p. 17.
} 
corpo produz e em seguida, rejeita, liberando: "Les matières fécales signifient, en quelque sorte, ce qui n'arrête pas de se séparer d'un corps en état de perte permanente pour devenir autonome, distinct des mélanges, altérations et pourritures qui le traversent. C'est au prix de cette perte seulement que le corps devient propre." ${ }^{351}$ Mas a perda de si é, também, a morte: “Ces déchets chutent pour que je vive, jusqu'à ce que, de perte en perte, il ne m'en reste rien, et que mon corps tombe tout entier au-delà de la limite, cadere, cadavre. ",352

O dejeto, "l'excrément et ses équivalents (pourriture, infection, maladie, cadavre, etc.)", ameaça o corpo que o contém, que o criou, e que é ele mesmo: "Si l'ordure signifie l'autre côté de la limite, où je ne suis pas et qui me permet d'être, le cadavre, le plus écouerant des déchets, est une limite qui a tout envahi. Ce n'est plus moi qui expulse, “je” est expulsé. La limite est devenue un objet. (...) Dépourvu de monde, donc, je m'évanouis." 353

"Rebaixar consiste em aproximar da terra", diz Bakhtin, ${ }^{354}$ e o excremento que remete à morte é, ao mesmo tempo, a fertilidade da terra - assim como o cadáver é também alimento do solo. Essa é a configuração de um corpo grotesco, definido também como um corpo-processo, em relação constante com a natureza. "A imagem grotesca caracteriza um fenômeno em estado de transformação, de metamorfose ainda incompleta” 355 , segundo Bakhtin. Um corpo grotesco "não está separado do mundo, não está isolado, acabado nem perfeito, mas ultrapassa-se a si mesmo (...) É um corpo eternamente incompleto, eternamente criado e criador. "356

O "transi", o corpo morto do macabro, poderia ser, portanto, considerado esse ser "intermediário", em processo de decomposição, fervilhando de vida parasitária enquanto volta à terra para fecundá-la, dissolvendo-se nela, virando outra coisa, seja esqueleto ou matéria orgânica. ${ }^{357}$

\footnotetext{
${ }^{351}$ KRISTEVA, 1983, p. 127.

${ }^{352}$ KRISTEVA, 1983, p. 11.

${ }^{353}$ KRISTEVA, 1983, p. 12.

${ }^{354}$ BAKHTIN, 1987, p. 19.

${ }^{355}$ BAKHTIN, 1987, p. 21.

${ }^{356}$ BAKHTIN, 1987, p. 23.

${ }^{357}$ Em sua tentativa de determinar a natureza do grotesco, Wolfgang Kayser afirma que as imagens da dança do morte pertencem ao seu repertório. Apesar de não desenvolver mais a proposição, lembra que "o crânio com seu esgar e o esqueleto a mexer-se são motivos que, com seu conteúdo macabro, entram na estrutura do grotesco. (KAYSER, 1986, p. 159).
} 
Esse movimento dialético de morte e vida é da ordem do grotesco: "os excrementos têm o valor de alguma coisa a meio caminho entre a terra e o corpo, alguma coisa que os une. São assim algo intermediário entre o corpo vivo e o corpo morto em decomposição, que se transforma em adubo. "358

É essa concepção de corpo que está no âmago da inversão carnavalesca (aparecendo na linguagem, por exemplo, pela paródia, pelo xingamento, pela grosseria ou pela obscenidade), um corpo que não é o do cânone clássico, harmonioso e ideal, mas que é festejado em toda sua materialidade. Tal ideia de corpo vai de encontro com o cadáver, puro despojo físico, pura matéria corpórea. A inversão carnavalesca testemunha o processo morte-vida do corpo macabro, em decomposição, voltando à terra, nutrindo-a. Se o realismo grotesco pressupõe esse eterno ciclo de vida e morte em uma mesma figura, o macabro traz à baila, e ao baile, um corpo que se dissolve e se reintegra - e por ser esse corpo grotesco, carnavalesco, ele também aparece na festa.

\section{A presença da Morte no Carnaval}

Apesar da importância do Carnaval no cotidiano medieval, a transição da Idade Média para a Renascença foi um período turbulento, como já vimos. Vida e morte se misturavam de maneira inextrincável naqueles séculos. $\mathrm{O}$ momento da passagem entre o século XIV e o século XV foi crucial para as mentalidades ocidentais. Além de marcar a fragmentação do sistema feudal, foi um momento de crise generalizada (superpopulação, escassez, fome, guerra dos cem anos, peste negra, revoltas urbanas). Via-se uma Europa dizimada, esfomeada, devastada. Para Georges Minois, não havia do que rir - ou melhor, o riso era então, nervoso, de agonia: "desabrido, cacofônico, contestatório amargo, infernal - o riso dos alegres esqueletos da dança macabra. ",359

Rir, nesse contexto era uma "reação pelo divertimento" - também uma forma de inversão, o paradoxo do sentimento diante de uma avalanche de mortandade e desesperança. Zombar da morte, colocando-a como convidada especial da festa era, por um lado, agregar a tristeza ao espaço-tempo da alegria; por outro, sinal de ousadia, uma

\footnotetext{
${ }^{358}$ BAKHTIN, 1987, p. 151.

${ }^{359}$ MINOIS, 2003, p. 252.
} 
vitória alegórica e temporária da humanidade sobre ela. Pode-se constatar, assim, que "os homens do século XV, enlouquecidos com as desgraças da época, brincaram com seus medos. Quando o mundo se torna absurdo, quando as catástrofes se acumulam a esse ponto, que fazer senão rir? Rir de tudo, rir de todos, dos excluídos e dos poderosos, da loucura e da morte, de Deus e do diabo. "360

E foi justamente daquele contexto turbulento que emergiram as representações do macabro do fim da Idade Média, que causaram impacto tão profundo no imaginário popular a ponto de invadirem outras esferas da vida. Serviram até como motivo decorativo, usados em objetos domésticos como móveis (se conhece, ao menos, uma cama em madeira, do século XVI, conservada no Musée des Arts d'Aix-la-Chapelle, e um baú de ébano no Musée des Antiquités d'Angers - ambos esculpidos com imagens de danças macabras) ${ }^{361}$ e acessórios indumentários (como o porta-adaga em latão cinzelado do Musée de l'Armée de Paris, que reproduz um fragmento da dança de Holbein $^{362}$ ). É de se imaginar que, assim como foi apropriado pela esfera privada dos utensílios particulares, o macabro muito provavelmente aparecia nas festas públicas que, como lembra Jacques Heers, serviam também para revelar esse repertório dos, por assim dizer, "temas da moda". 363

Foi dessa maneira que, no decênio de 1490, no então famoso carnaval de Florença, inaugurou-se a tradição do desfile do "Triunfo da Morte", homônimo ao motivo iconográfico criado pouco tempo antes. Em um imenso carro, ${ }^{364}$ todo coberto de tapeçarias negras, ornado de ossadas e cruzes brancas, transportavam uma grande imagem da Morte armada com uma foice. A seus pés, caixões de onde saíam pessoas

\footnotetext{
${ }^{360}$ MINOIS, 2003, p. 252.

${ }^{361}$ GABION, 2000, p. 93.

362 O objeto é bastante conhecido, apesar do site do Museu sugerir sua data de origem como ca 1400, anterior, portanto, ao nascimento do artista. Ver em: www.musee-armee.fr/collections/base-de-donnesdes-collections/objets/basilard.html

Há também à venda, no site da casa de leilões de objetos de artes Christies, um porta-fumo alemão para cachimbos do século XVII, em madeira esculpida com o tema da dança macabra. A pesar de parte da coleção "Le cabinet des curiosités" dos colecionadores Jacques e Galila Hollander, nada mais se disponibiliza de informações sobre o objeto. Ver em: www.christies.com?Le-cabinet-de-curiosites24570.aspx

${ }^{363}$ Para lá dos meros divertimentos gratuitos, dos beberetes e das danças, e à margem de qualquer intenção alegórica, as festas anteriores à Quaresma exprimiam curiosidade, o desejo de agradar. Revelavam, por outro lado, embora de tão difícil interpretação, uma espécie de repertório dos temas da moda, apreciados pelo numeroso público da cidade. (HEERS, 1987, p. 175)

${ }^{364}$ A presença de carros alegóricos nos desfiles de Carnaval evoca a tradição romana dos carrus navalis, procissão de barcos decorados em ocasiões festivas - daí provém uma das teorias sobre a etimologia da palavra Carnaval. (CIRLOT, Juan Eduardo. Verbete "Barco", Diccionario de Simbolos. Barcelona, Siruela, 1997, p. 107)
} 
fantasiadas de esqueletos, que levantavam as tampas de seus falsos túmulos a cada batida do tambor. Atrás do carro, um coro vestindo preto e portando máscaras de feições cadavéricas, segurando tochas, entoando um canto denominado "Miserere", cujos versos lembram muito a lição do "Encontro dos três vivos e dos três mortos": "Nós fomos o que sois, vós estareis morto, tal como nos vedes. ", 365

Colocando a Morte e os mortos no meio dos festejos, o grotesco medieval e renascentista cumpria seu papel regenerador: "associado à cultura cômica popular, representa o terrível através de espantalhos cômicos, isto é, na forma do terrível vencido pelo riso. O terrivel adquire sempre um tom de bobagem alegre, ${ }^{, 366} \mathrm{de}$ acordo com Bakhtin. Subvertendo os símbolos da agonia, fazendo troça e ridicularizando-os, procurava libertar o mundo da tristeza, vencendo-a pelo riso. Além do mais, como lembra Heers, "não era difícil imaginar nos ornamentos e nas máscaras, nas cenas representadas nos carros, ou nas fantasias, figuras que traduziam os desejos de desafiar os interditos, de exaltar esta ou aquela brincadeira proibida. ${ }^{, 367}$ A imagem da Morte no meio do divertimento devia, efetivamente, chocar e causar impacto e, por isso mesmo, devia ser ainda mais apreciada.

A possibilidade desses momentos de descontração e extravasamento sendo invadidos, como numa inesperada reviravolta, pelo horror da mortandade, transformando-se numa alegoria bizarra do trespasse, ultrapassa os séculos, desembocando no XIX. As mutações sofridas pelas danças macabras oitocentistas eram já sintomáticas dessa idéia: mortos confraternizando, promovendo banquetes e fazendo orgias, apropriando-se dos recursos dos vivos para se divertirem. É significativo que a expressão "dança macabra" apareça, ainda que muito rapidamente, na segunda parte do Fausto de Goethe - e, talvez, essa ligeira menção tenha até mesmo contribuído para a curiosidade a respeito do tema. A narrativa mostra a preocupação do porta-voz do Imperador ao anunciar a festa de máscaras do Mardi Gras: não como os vulgares e sinistros tipos de "Totentänzen" da tradição medieval, mas como uma artística emulação de uma mascarada florentina da Renascença, mais civilizada (segundo Heers, desde a época dos Médicis, "o Carnaval florentino apresenta-se-nos como um magnífico exemplo de festa divertida, popular, outrora contestatória, depois recuperada para

\footnotetext{
${ }^{365}$ A descrição desse "Triunfo" foi feita com base nas informações em Georges Minois (2003, p. 267) e Jacques Heers (1987, p. 194).

${ }^{366}$ BAKHTIN, 1987, p 34,

${ }^{367}$ HEERS, 1987, p. 181 .
} 
melhor proveito do homem no poder, e dos seus. (...) limita-se a oferecer-nos uma imagem pacifica da cidade satisfeita com ela própria.”368 ). Goethe chegou experienciar um carnaval italiano em 1788, acontecimento que o teria impressionado muito positivamente, conforme seu depoimento em um ensaio denominado "Das Römische Karneval”369,

Apesar da distância temporal, a vivência do poeta alemão parece muito próxima da original, renascentista. $\mathrm{O}$ assunto, como se sabe, o interessava particularmente, tanto que foi organizador das festas da corte de Weimar, oferecendo bailes e eventos inspirados por aqueles que presenciou. ${ }^{370}$ Ao falar do Carnaval de rua, Goethe admite seu olhar de estrangeiro, que vê pela primeira vez "une si grande masse vivante d'objets sensibles. "371 Um aspecto do evento fica claro mesmo àqueles que acabavam de conhecê-lo: "Le carnaval de Rome n'est pas proprement une fête qu'on donne au peuple, mais que le peuple se donne à lui-même. "372 A festa popular feita por e para $\mathrm{o}$ povo quase não conta com a estrutura do Estado (“L'État fait peu de préparatifs, peu de dépense (...) la police le dirige d'une main légère "373). Sem os brilhos e os faustos que "éblouisse les yeux des spectateurs" das festas da Igreja ou dos castelos, que impressionam pelos brilhos, fogos e graves procissoes piedosas, o que mobilizava o Carnaval de rua era o fato de que "chacun peut se montrer aussi fou, aussi extravagant qu'il voudra, et qu'à exception des coups et du poignard, presque tout est permis. „374 Assim que o sinal para a festa começar era dado, "le grave Romain, qui se garde soigneusement de tout faux pas durant l'année entière, dépose tout à coup ses scrupules et as gravité.",375

Nesse estado em que quase tudo era permitido, todos eram iguais: "la différence entre les grands et les petits semble um moment suspendue. "376 Livres dos formalismos que marcam a separação entre a classes, as pessoas se aproximavam umas das outras, em uma mútua sensação de "bonne humeur universelle"377 já estranhos à era

\footnotetext{
${ }^{368}$ HEERS, 1987, p. 201-218.

${ }^{369}$ que, aqui, será citado em sua tradução francesa de 1862.

${ }^{370}$ Goethe foi o organizador dos folguedos e mascaradas da corte do duque Carlos Augusto (BAKHTIN, 1987, p. 214)

${ }^{371}$ GOETHE, 1862, p. 458.

${ }^{372}$ GOETHE, 1862, p. 458.

${ }^{373}$ GOETHE, 1862, p. 459.

${ }^{374}$ GOETHE, 1862, p. 459.

${ }^{375}$ GOETHE, 1862, p. 463.

${ }^{376}$ GOETHE, 1862, p. 459.

${ }^{377}$ GOETHE, 1862, p. 459.
} 
contemporânea. Segundo Goethe, durante aqueles dias, os romanos podiam reviver as antigas saturnais, que a fé em Cristo fez recuar, mas nunca conseguiu abolir totalmente.

Tudo começava numa das vias principais, a Corso, entulhada de gente: "la longue et étroite rue dans laquelle tournoie une foule innombrable que ne peut se voir d'um coup d'oeil dans toute son étendue; à peine distingue-t-on quelque chosedans le théâtre du tumulte que l'oeil peut saisir."378 A massa avançava por ruas previamente decoradas com flores, véus e tapetes, transformadas assim em grandes salões de baile: “les petites gens, les enfants, sont dans la rue, qui cesse d'être une rue; elle ressemble plutôt à une grande salle de fête, à une immense galerie decorée." 379 Entregue aos prazeres, às batalhas de confetti e de frutas e à bebida, a multidão aumentava a cada hora, "les masques deviennent plus nombreux,",380 assim como os travestidos - homens usando trajes de mulheres de classes inferiores, com o peito descoberto e ar de coqueteria, provocando todos que passam por eles, com insinuações ou grosserias; mulheres fantasiadas de Polichinelo. Cada mascarado representava sua nova identidade, como num teatro sem palco - como o falso advogado que saltava declamando defesas como se estivesse diante de um tribunal, atacando outros foliões com ameaças de processos e inventando motivos para eles. Muitos eram os que se fantasiavam de mendigos e mendicantes: cabelos longos, "un masque tout blanc,"381 uma pequena vasilha de água, um cajado e um chapéu nas mãos, com os quais esmolavam uma prenda qualquer às pessoas. "Les habits ordinaires de tous les étais servent aussi de masques, " ${ }^{382}$ e também a indumentária antiga, o vestuário de outros povos, de outras épocas, tudo virava disfarce. Alguns inventavam uma figura extravagante para fazer graça, como o mascarado que portava grandes chifres removíveis e os colocava quando se aproximava de um casal, fazendo tocar vivamente os sininhos que tinham nas pontas e provocando grandes gargalhadas.

O desfile de carros acontecia todos os dias do Carnaval, mas era no último que se viam os mais elegantes e magníficos. Eles eram decorados e mesmo os cavalos ganhavam fantasias. Sobre os carros, as mais belas romanas eram dispostas e elas acenavam alegremente para o público. Alguns carros eram temáticos e neles se

\footnotetext{
${ }^{378}$ GOETHE, 1862, p. 459.

${ }^{379}$ GOETHE, 1862, p. 463.

${ }^{380}$ GOETHE, 1862, p. 463.

${ }^{381}$ GOETHE, 1862, p. 465.

${ }^{382}$ GOETHE, 1862, p. 466.
} 
encenavam representações mitológicas e alegóricas, cada um buscando se distinguir e chamar mais atenção que o outro. As sacadas dos prédios se enchiam de gente para assitir aos espetáculos. ${ }^{383}$

Mas a experiência italiana não era padrão - e mesmo ela possuía seus momentos de transtorno. ${ }^{384}$ Durante os dias do Carnaval, onde quer que fosse, o estrangeiro possivelmente se sentiria desprotegido fundido à massa local, vulnerável à violência anônima dos mascarados.

O descontrole causado pelo clima de licenciosidade e pelos excessos era frequentemente uma preocupação das autoridades e, no século da Razão, os festejos encontram inimigos: "os Carnavais, as mascaradas não são resquícios de fanatismo, de ritos grosseiros e supersticiosos, intoleráveis na França esclarecida e regenerada? Por toda parte, as novas autoridades tenatm proibir as festas tradicionais" ${ }^{\prime 385}$ - e, certamente, o movimento não se limitou à França. Bakhtin comenta a absoluta incompreensão (e aversão, em alguns casos) dos Iluministas diante da obra de Rabelais, ${ }^{386}$ o que é bastante significativo em expor a repulsa por essas manifestações "grosseiras" da cultura popular. O realismo grotesco do corpo carnavalesco (que, lembremos, é também o corpo macabro), não condizia com a imagem higienizada do corpo burguês vitoriano, fechado para o mundo, limpo, cujas necessidades fisiológicas e as repugnâncias eram escrupulosamente dissimuladas - e, no limite, escondidas, negadas.

Ele se ligava a outro tipo de grotesco, romântico, que consistia numa "reação contra os cânones da época clássica e do século XVIII" e que reinterpretava o grotesco medieval. ${ }^{387}$ Porém, ao contrário do grotesco da Idade Média e do Renascimento, diretamente relacionado com a cultura popular e com a comicidade, o grotesco

\footnotetext{
${ }^{383}$ Mas Goethe também experiencia um grande baile de máscaras do beau monde no Teatro Aliberti, magnifiquement éclairé na ocasião. Lá, mascarados e não mascarados se misturam aos fantasiados com pompa, em trajes que imitavam épocas diversas e estátuas famosas ou divindades egípcias, gregas e romanas. Nessas festas, se dançava em filas, como nos bailes da corte, apesar de que a ocasião carnavalesca fazia os gestos serem mais afetados e cênicos - alguns casais até mesmo representavam cenas. (GOETHE, 1862, p. 480.)

${ }^{384}$ Goethe fica particularmente sensibilizado com a bagunça e a sujeira resultante da corrida de cavalos, competição que marcava o fim de cada dia de desfiles de carros. (1862)

${ }^{385}$ MINOIS, 2003, p. 463.

${ }^{386}$ No conjunto, os filósofos das Luzes não souberam compreender nem apreciar Rabelais (...) Para Voltaire, o livro de Rabelais é algo extravagante e ininteligível. É uma mescla de erudição, sujeira e aborrecimento. (BAKHTIN, 1987, p. 100-101. Sobre o assunto, ver todo o capítulo 1, "Rabelais e a história do riso")

${ }^{387}$ BAKHTIN, 1987, p. 33.
} 
romântico é do isolamento, grave, "espécie de carnaval que o indivíduo representa na solidão". A corporeidade de suas representações se perdem em função do pensamento, das abstrações, como se a sensação carnavalesca do mundo tivesse deixado de ser vivida de fato. ${ }^{388}$ Quando o século XIX olha para o grotesco medieval, perde a compreensão dessa comicidade reguladora, e interpreta suas manifestações (como a Dança Macabra, por exemplo, com seus mortos alegres e saltitantes) "com absoluta seriedade". 389

No Promontorium Somnii, série de elocubrações sobre a arte e a literatura, Victor Hugo claramente mistura as duas vias, retomando a alegoria da dança macabra numa leitura contemporânea, concebendo-a como a própria vida (“L'homme danse volontiers la danse macabre et il la danse sans le savoir”). Nessa divagação poética, o baile de Carnaval não passa de uma festa de fantasmas, um sabá (ambas imagens medievais de inversão carnavalesca), onde a fantasia confunde-se com a mortalha e a máscara é uma "face morta" em meio ao divertimento.

L'homme danse volontiers la danse macabre, et, ce qui est bizarre, il la danse sans le savoir. C'est à l'heure où il est le plus gai qu'il est le plus funèbre. Un bal en carnaval, c'est une fête aux fantômes. Le domino est peu distinct du linceul. Quoi de plus lugubre que le masque, face morte promenée dans les joies! L'homme rit sous cette mort. La ronde du sabbat semble s'être abattue à l'Opéra, et l'archet de Musard pourrait être fait d'um tibia. Nul choix possible entre le masque et la larve. Stryga vel masca. Qui sait si cette cohue obscène n'a pas, en venant ici, laissé derrière elle des fosses vides? ${ }^{390}$

\section{A máscara}

Contribui para esse desconforto diante da festa carnavalesca a impressão do anonimato generalizado, causado pelo uso da máscara. O mascaramento é uma das características primordiais da inversão do carnaval, presente desde seus primeiros registros. Permitindo assumir outra identidade ou mesmo identidade nenhuma, facilita a

\footnotetext{
${ }^{388}$ BAKHTIN, 1987, p. 33.

${ }^{389}$ BAKHTIN, 1987, p. 44.

${ }^{390}$ HUGO, 1937, p. 304.
} 
representação de outros papéis sociais. Não tinha, na leitura de Bakhtin, um sentido negativo em seus usos nos ritos carnavalescos medievais e renascentistas. Traduziam " $a$ alegria das alternâncias, a alegre relatividade, a alegre negação da identidade e do sentido único”, eram a máxima expressão “das transferências, das metamorfoses, das violações das fronteiras naturais, da ridicularização, dos apelidos”. Mas, quando vista pelos românticos:

a máscara, arrancada da unidade da visão popular e carnavalesca do mundo, empobrece-se e adquire várias outras significações alheias à sua natureza original: a máscara dissimula, encobre, engana, etc. Numa cultura popular organicamente integrada, a máscara nao podia desempenhar essas funçoes. No Romantismo, a máscara perde quase completamente seu papel regenerador e renovador, e adquire um tom lúgubre. Muitas vezes ela dissimula uma vazio horroroso, o "nada". ${ }^{391}$

Seu aspecto sinistro de dissimulação é bastante evocado pelos escritores do século XIX. Victor Hugo, no trecho citado, fala da "face morta" da máscara carnavalesca, fisionomia sem expressão ou congelada, introduzida entre os divertimentos. Daí seu mistério - e também seu perigo - para além da mera brincadeira. Jean Lorrain, em suas Histoires de masques, traça uma imagem igualmente assustadora das mascaradas: "Ils sont bruyants, débordants de mouvements et de gestes, ces masques, et pourtant leur gaieté est triste; ce sont moins des vivants que des spectres. Comme les fântomes, ils marchent pour la plupart enveloppés dans des étoffes à long plis, et, comme les fantômes, on ne voit pas leur visage." 392 A composição lembra as pinturas de temas carnavalescos de Goya.

Há ainda o caso da morte mascarada, da face que, já morta, se disfarça de vivo para penetrar no baile. É a Morte Rubra, de Poe. Ou ainda, a estatuazinha de terracota, de Ernest Christophe, que inspirou Baudelaire em seu poema Danse Macabre, uma personificação feminina da Morte, portando vestido de folhos e xale nos ombros, segura também, na mão direita, uma máscara. Sua cara descarnada de caveira recebe um delicado e falso rosto para participar da festa, iludindo momentaneamente aqueles que a vêem adentrando o salão. Como a figura da morte criada por T. Gautier (em $L a$

\footnotetext{
${ }^{391}$ BAKHTIN, 1987, p. 35.

${ }^{392}$ LORRAIN, 1900, p. 4
} 
comédie de la mort), que muda de máscara e de traje mais do que uma atriz - e como ela, sabe dissimular, não se mostrando como uma "maigre carcasse" que exibe os dentes fazendo caretas horríveis:

La mort est multiforme, elle change de masque E d'habit plus souvent qu'une actrice fantasque; Elle sait se farder,

Et ce n'est pas toujours cette maigre carcasse, Qui vous montre les dents et vous fait la grimace Horrible à regarder. ${ }^{393}$

Em uma das gravuras de The English Dance of Death, de Rowlandson (1814), é exatamente assim que a Morte se revela: tirando o disfarce no meio do salão, entre os fantasiados, causando horror em todos à sua volta. Os versos sob a imagem comparam à festa à vida, que a Morte interrompe abruptamente ("Such is the power \& such is the strike. / That ends the Masquerade of Life"). (Figura 1)

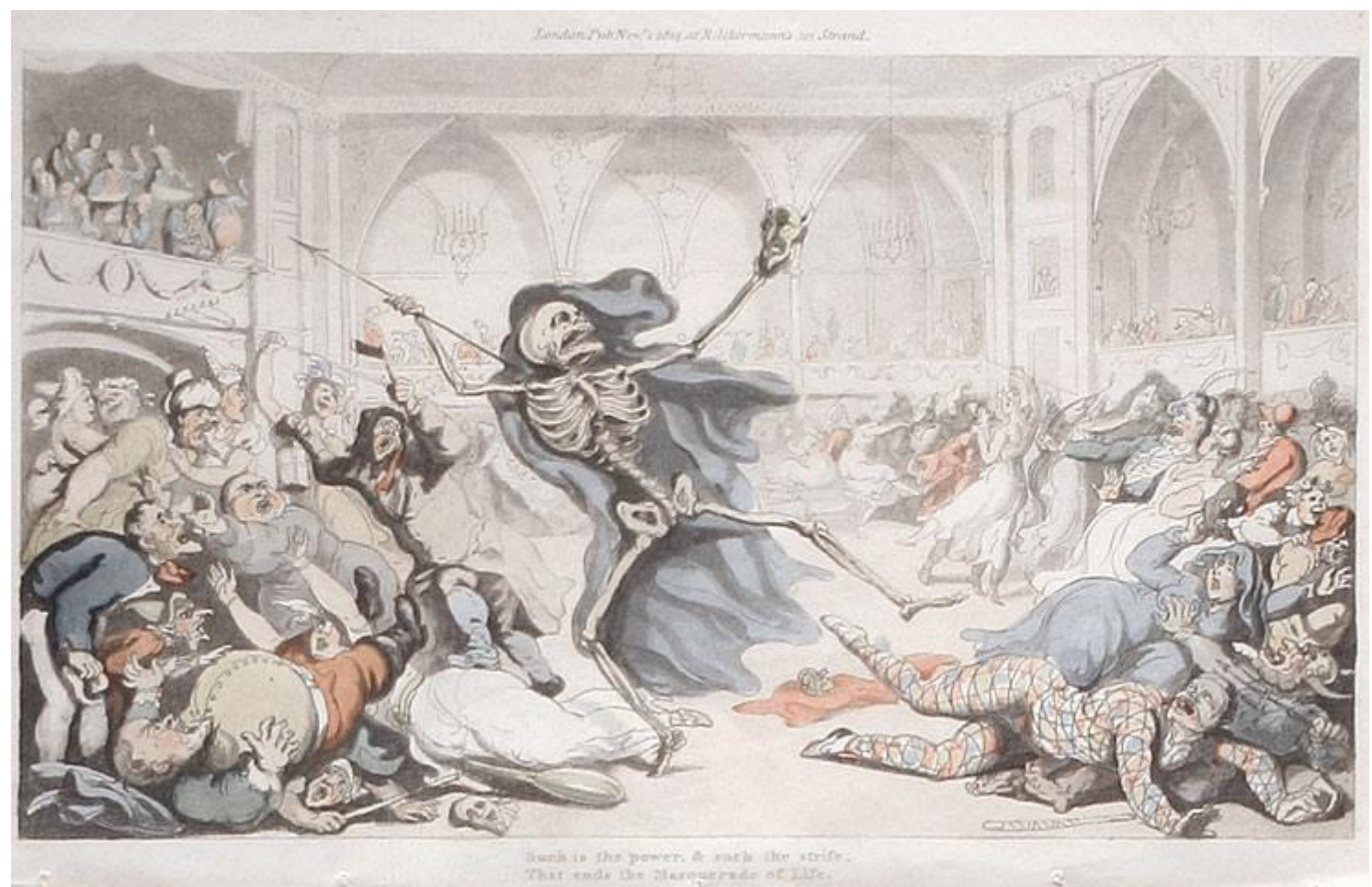

Figura 1

${ }^{393}$ GAUTIER, 1838, p.39. 
Esse foi, a propósito, o uso de um outro tipo de máscara na Idade Média Tardia: não a da folia, mas a máscara mortuária, que surge no começo do século XIV. ${ }^{394}$ Artefatos feitos em materiais diversos, esculpidas e estilizadas, para serem colocados sobre a fronte do defunto eram de uso comum nas cerimônias fúnebres da Antiguidade. Mas a máscara mortuária medieval, feita de gesso ou de cera, não mais escondia sua fisionomia. Pelo contrário, registrando seus traços e simulando sua aparência de vivo (eram moldadas no rosto do moribundo ou imediatamente depois do falecimento), ajudavam a disfarçar as distorções faciais pós-mortem. Com o desenvolvimento de pompas funerárias mais complexas entre a nobreza a partir do Renascimento, o momento do enterro se adiava em prol de velórios abertos ao público ou mesmo de eventos que exigiam o corpo presente, como a última missa ou a procissão até o local do sepultamento - Michel Vovelle lembra o exemplo de Carlos VI da França, que permaneceu mais de dez dias insepulto após o óbito, participando de exéquias oficiais. A apresentação do corpo ao natural se tornava inapropriada e adotou-se o hábito de substituir todo o cadáver por uma efígie ou vestí-lo, cobrindo seu rosto com o falso semblante. ${ }^{395}$ Esse uso da máscara como disfarce que cobre um cadáver, de feições possivelmente desfiguradas e horríveis, simulando seu rosto de vivo e escondendo a deterioração, tão comum nos séculos modernos, talvez tenha contribuído para o imaginário da máscara aterrorizante dos oitocentos.

O medo da massa toda disfarçada, ou mesmo de um único indivíduo transfigurado em meio à multidão, e, por isso, apto a cometer qualquer tipo de infração, foi um dos motivos que levou à divisão do Carnaval entre festa pública e evento fechado a partir do final do século XVI. ${ }^{396}$ Aumentando a distância entre cultura popular

\footnotetext{
${ }^{394}$ VOVELLE, 1983, p. 111.

${ }^{395}$ En France le masque funèbre des rois n'est indiscutable qu'en 1461 (Charles VII), l'usage est attesté en Italie vers la même époque (Bernardin de Sienne 1444, Brunelleschi 1446), en Angleterre plus tard sans doute. (...) Ce trait, dans lequel on a parfois voulu voir un moyen d'escamoter la dépouille mortelle, mais qui est aussi bien - et à mon sens plus encore - une manière de pérenniser l'apparence de la vie, connaît une bien curieuse évolution. (VOVELLE, 1983, p. 112 e 335)

${ }^{396}$ O Carnaval muda de tom no século XVI, considera Geroges Minois, dando uma série de exemplos de como a festa de rua passava a ser um evento violento, de ataques religiosos e reinvidicações políticas, tendo de ser interditada em vários lugares da Europa pelos poderes administrativos, especialmente naqueles em que a Reforma se alastrava. A mistura de comemoração desenfreada num espaço-tempo de exceção à normalidade com vinho e disfarces de máscaras resultava em um estado difícil de conter. O Carnaval de Romans, em 1580, por exemplo, terminou com uma dezena de mortos após conflito armado. Minois faz uma lista extensa de outros eventos carnavalescos terminados em tragédia entre os século XVI e XVII, no capítulo Acabou-se o riso de sua História do riso e do escárnio (2003, p. 317 - 363). Caro Baroja comenta as proibições de brincadeiras violentas no Carnaval de Madrid lançadas pela prefeitura, primeiro em 1586, repetindo-se em 1599, 1606, 1607, 1608, 1612, 1613, 1624, 1626, 1629, 1644, 1646,
} 
e de elite, ocorriam as primeiras festividades de salão, uma reação às catárticas e imprevisíveis manifestações de massa. A demonização do Carnaval acontecia paralela ao mesmo movimento em relação aos sabás, ambos banidos da sociedade renascentista, ora por rememorarem os tempos medievais, ora por exporem uma realidade às avessas. Há de se lembrar do contexto dessa Europa Ocidental, desestabilizada pelas forças reformadoras, humanistas e absolutistas, que passava a problematizar a inversão carnavalesca das normas. O mundo já estava descontrolado demais e as imagens grotescas dos quadros de Bosch ou de Bruegel não pareciam mera ficção.

\section{Dois Carnavais}

O Carnaval finalmente se divide em dois em meados dos seiscentos. ${ }^{397}$ Por um lado, assumia a forma de festejo urbano, mais controlado e institucionalizado, mas ainda caótico, persistindo as danças lúbricas, o travestimento, gestos exacerbados, canções populares de duplo sentido, obscenidades. Funcionando como válvula de escape, o povo exorcizava, nele, suas angústias e o peso da existência, ainda que debaixo do olhar vigilante das autoridades. O outro, evento aristocrático e oficial, sob forma de festa de salão com mascarada, limitado às elites. Neste, a festa se civiliza, se refina, se intelectualiza - como, afinal, acontecia com todos os hábitos da nobreza (efeito do "processo civilizador", que teve em Norbert Elias seu grande intérprete). Comemoravase com fartura e fausto: no Carnaval cortesão não havia lugar para a tristeza, tampouco para o macabro, pois a riqueza celebra a vida. Daí a decisão do príncipe Próspero, na Máscara da Morte Rubra, de E.A.Poe, de oferecer uma mascarada em seu castelo, como se o luxo fosse um escudo; como se fosse possível isolar-se, assim, da epidemia que grassava do lado de fora.

De qualquer maneira, "já não "Festas dos Loucos” mas festas dos ajuizados, dos dignos recompensados. "398 As Festas dos Loucos, aliás, nessa conjuntura,

1651, 1699, 1673. Seguimos avanzando en el tiempo y las autoridades, imperturbables, dan leyes semejantes hasta cuarenta veces, según mi cuenta, de 1721 a 1773. (1965, p. 154)

${ }^{397}$ MINOIS, 2003, p. 458.

${ }^{398}$ HEERS, 1987, p. 219. 
ensaiavam sua despedida: mesmo havendo registros até os primeiros decênios do século XVII, à medida que o carnaval se sistematizava, elas foram escasseando até desaparecerem. O divertimento desregrado e desenfreado dava lugar aos mais controlados e organizados: cortejos e espetáculos feitos no espaço público passavam a corresponder a determinadas intenções, políticas até, e, desde então, a espontaneidade não foi mais possível. ${ }^{399}$

Assim, depois do Renascimento, de acordo com Bakhtin, assiste-se a um processo de redução das formas carnavalescas populares, que perdem seu caráter de transgressão ritualizada implicando a metamorfose dialética da ordem para negá-la e reafirmá-la incessantemente, para se tornarem apenas... festas: "A visão do mundo carnavalesco com seu universalismo, suas ousadias, seu caráter utópico e sua orientação para o futuro, começa a transformar-se em simples humor festivo. "400

Esse mesmo processo de separação do Carnaval verificou-se no Brasil do século XIX quando, após a chegada da corte ao Rio de Janeiro, fomentou-se pela primeira vez uma cultura cortesã, cujos refinamentos alterariam a maneira de se vivenciar o período carnavalesco. Até então, a brincadeira praticada nos dias gordos que antecediam a Quarta-Feira de Cinzas era o Entrudo. Atividade popular aberta a todos, o Entrudo tinha origem portuguesa e tendo penetrado no Brasil no século XVI, difundiu-se pelo Nordeste, Rio de Janeiro, Minas Gerais, São Paulo e até Santa Catarina e Rio Grande do Sul. ${ }^{401}$ Tratava-se do jogo de atirar água com seringas e vasilhas, ovos ou finíssimas bolinhas de cera cheias de água perfumada (chamadas de laranjinhas ou limões-decheiro). Podia-se, logo após molhar o alvo, lançar um punhado de farinha ou polvilho, piorando sua situação e aumentando a graça do ataque (como mostra a gravura de JeanBaptiste Debret, Dia d'entrudo, de 1823).

Em As Mulheres de Mantilha, Joaquim Manuel de Macedo nos presenteia com um depoimento bastante completo sobre a farra que tomava conta da cidade:

$\mathrm{O}$ entrudo era durante os três dias que se chamam do carnaval, o jogo delirante de todas as idades, desde o menino até o velho, de ambos os sexos, e de todas as classes sa sociedade, de todas, porque também os escravos jogavam entre

\footnotetext{
${ }^{399}$ HEERS, 1987, p. 223 a 227.

${ }^{400}$ BAKHTIN, 1987, p. 30.

${ }^{401}$ MONTEIRO, 2010, p. 3.
} 
si. O jogo consistia essencialmente em molharem-se uns aos outros; o exaltamento e o frenesi dos jogadores, uma vez travado o combate, não se limitavam a água e com outros meios enxovalhavam, como podiam (...)

Quem não queria jogar o entrudo, trancava as portas e janelas de sua casa, e não saía à rua durante três dias. ${ }^{402}$

Qualquer um na rua era uma vítima em potencial. Verdadeira guerra pública, o Entrudo envolvia toda a gente, de todas idades e condições sociais - inclusive e especialmente os negros, que tinham na festa a oportunidade de se misturar e de folgar com os brancos. Essa presença negra expunha o ridículo das maneiras "civilizadas" da corte que impressionavam a população média. Para brincar o carnaval, muitos pintavam o rosto e fantasiavam-se de europeus, simulando as mesuras e os trejeitos afetados da etiqueta aristocrática, provocando e caçoando de seus opressores. "Tal prazer não é difícil de compreender: além da folga e do divertimento, os negros faziam do entrudo ocasião para inverter os sinais, e rir dos brancos. "403

Mas a entrada da referência cortesã na cultura brasileira despertou novas demandas de sociabilidade. Em 1840 realizou-se o primeiro "carnaval veneziano de máscaras" no Rio de Janeiro, no teatro São Januário, que parece ter sido um grande sucesso - tanto que se estabeleceu como evento oficial: "separou-se a festa de rua, popular e negra, embora de origem portuguesa - o entrudo -, da festa do salão branco e segregado, o Carnaval." 404 Dois anos após a proibição do Entrudo, anunciava-se evento semelhante em São Paulo, em 1856, em clubes privados da elite paulistana. ${ }^{405}$

\footnotetext{
${ }^{402}$ MACEDO, 1988, p 25.

${ }^{403}$ CUNHA, 2001, p. 57.
}

A autora complementa, mais adiante: São inúmeras as referências ao fato de que eles pintavam a "carapinha"e as próprias peles com farinha ou alvaiade, realçandoa s bochechas com vermelhão. Caracterizando-se de "brancos", criavam um simulacro do outro para ridicularizá-lo. Tal brincadeira, no contexto de uma sociedade escravista, não pode ser compreendida apenas como consentimento senhorial para permitir uma "válvula de escape"por meio da qual a dominação possa ser realimentada. Ao contrário, ela serve para explicitar e ampliar o mal-estar entranhado nas relações raciais e sociais: trata-se sem dúvida de uma expressão teatralmente cômica dos conflitos e tensões do dia-a-dia, elaborando um discurso sobre a desigualdade e a injustiça ao explicitar a percepção que os negros tinham dos senhores."(p. 58) Todo o estudo de Maria Clementina Cunha sobre o Carnaval se baseia na análise dessas tensões sociais que emergiam durante durante os festejos, especialmente as de cunho racial.

${ }^{404}$ ALENCASTRO, in: NOVAIS, 1997, p. 52.

${ }^{405}$ ALENCASTRO, in: NOVAIS, 1997, p. 52. 
Esse novo Carnaval fechado, promovido nas mansões dos mais ricos ou nos teatros e agremiações, tornou-se símbolo de status - tanto oferecê-los quanto participar deles, fosse como convidado ou pagante. As fantasias aí eram rebuscadas e não andrajos improvisados, as máscaras eram compradas no comércio especializado, que as importava diretamente da Itália. $^{406}$ De lá, também vinham outros costumes carnavalescos, como o desfile com carros alegóricos decorados e as personagens da commedia dell'arte, como Pierrô, Arlequim, Colombina, que "desconhecidas no Brasil, incorporam-se ao folclore urbano e literário nacional. "407

Apesar de interdito, o festejo de rua nunca foi efetivamente extinto: "a morte do entrudo foi comemorada muitas vezes, desde a década de 50 do século XIX. Sua ressurreição a cada ano era também objeto dos mais irados comentários escritos ou gráficos [na imprensa]. "408 Entre os decênios de 1850 e 1860, os clubes e agremiações carnavalescas começavam a organizar as passeatas de carros nas principais avenidas (primeiro no Rio de Janeiro e logo em São Paulo e outras capitais). A lógica invertida do Carnaval se tornava mais complexa com essa discrepância a céu aberto: ao lado dos grupos abastados que tentavam instituir o "verdadeiro Carnaval” de inspiração européia, coexistiam as selvagens laranjinhas e bisnagas d'água. ${ }^{409}$

Além das fantasias de falsos nobres, geralmente envergadas pela população mais pobre e negra, um outro personagem, saído dessa mesma camada, aterrorizava os foliões na Corte: o diabinho.

Com suas roupas encarnadas, chifres e longas caudas pontudas, os endemoniados "diabinhos" personificavam os horrores dos partidários do Carnaval europeizado - mas também encontravam paralelo na grande procura pelas caríssimas fantasias e máscaras de Mefisto que apareciam anunciadas pelas casas finas da rua do Ouvidor. Fantasia antiga, que por muitas décadas ocupou lugar de destaque nas escolhas da população mais pobre da cidade, mas que causava um crescente temor $(\ldots)^{410}$

\footnotetext{
406 ALENCASTRO, in: NOVAIS, 1997, p. 52.

${ }^{407}$ ALENCASTRO, in: NOVAIS, 1997, p. 52.

${ }^{408}$ CUNHA, 2001, p. 66.

${ }^{409}$ CUNHA, 2001, p. 25.

${ }^{410}$ CUNHA, 2001, p. 37.
} 
O temor era explicitado pela imprensa que durante os dias de festa noticiava roubos e confusões diversas causadas pelos diabos, identificados como escravos, forros e capoeiras, que se aproveitavam da condição temporária de anonimato. ${ }^{411}$

Mas não era apenas a presença mascarada do negro que importunava o folião. Moritz Lambert, viajante alemão que visitava o Brasil em meados do século oferece um relato pungente da sensação de estranheza causada pelo contato com a multidão nos festejos de rua:

No domingo de entrudo de tarde começam a percorrer as ruas que pouco a pouco vão se enchendo de diversas sociedades carnavalescas, munidas dos instrumentos de música os mais variados. Depois, aparecem os mascarados bem fantasiados em carros, a cavalo e a pé. O povo cada vez aumenta mais; o ruído torna-se atordoador; a confusão, medonha.[...] As sacadas que nenhuma casa aqui dispensa estão apinhadas na maior parte de senhoras [...]. Atiram limões aos centos sobre os mascarados; mas sobretudo o que mais as diverte é atirá-los sobre amigos e conhecidos, que procuram garantir-se e que por seu lado correspondem a essa amabilidade [...] De repente, como por encanto, nessa imensa confusão, há uma interrupção, faz-se silêncio e, ao longe, ouve-se o som de timbales, castanhetas e tambores [...] O clangor vai aumentando cada vez mais até transformar-se finalmente em ruído estrondoso, que agora retine pelas ruas de modo selvagem e guerreiro [...] $\mathrm{Na}$ frente caminham duas fileiras de negros corpulentos tocando seus instrumentos [...] Atrás vem uma multidão selvagem, gritando e gesticulando $[\ldots]^{412}$

Há de se admitir que a cena diverge drasticamente do que se esperaria de uma animada e colorida festa de carnaval. A atmosfera de "selvageria" causa apreensão, anunciando que, dentro da massa em êxtase, tudo pode acontecer. A tensão é nítida no relato: a molhadeira do entrudo podia, facilmente, se transformar em violência, potencializada pela mistura entre raças, entre as classes, entre os sexos, pela gritaria, pelo batuque pulsante da percussão, pelo álcool. "Nas ruas e praças a multidão estrepitosa tresloucava sem medida; os gritos e as gargalhadas, às vezes injúrias e

\footnotetext{
${ }^{411}$ CUNHA, 2001, p. 37.

412 Moritz Lamberg citado em CUNHA, 2001, p. 23. (Os grifos são meus.)

Cunha chama a atenção para o fato de que o relato se refere à Recife, e não ao Rio de Janeiro - "mas seus elementos, como as sociedades carnavalescas, os mascarados, as famílias ricas nas sacadas, os limões-de-cheiro, os préstitos"à moda africana", etc, são constantes em diversas capitais brasileiras e, sobretudo, no Carnaval da Corte desse período." (2001, p. 317, nota 2 do Capístulo 2).
} 
violências (...)" - a advertência é de Joaquim Manuel de Macedo - "sobravam os casos em que os velhos mais austeros e severos e as donzelas mais mimosas e as mais acanhadas, aborrecendo o entrudo, desde que, a despeito de suas pragas e de seus protestos, se viam molhados, perdiam as cabeças, e se tornavam furiosos jogadores do jogo d'água. " ${ }^{113}$ É o que mostra a litografia do carioca Frederico Guilherme Briggs, Os resultados do entrudo, de 1840 (figura 2). A confusão e a licenciosidade carnavalesca terminavam muitas vezes em gravidez indesejada, doenças, chibatadas, prisão, ferimentos graves... e morte.

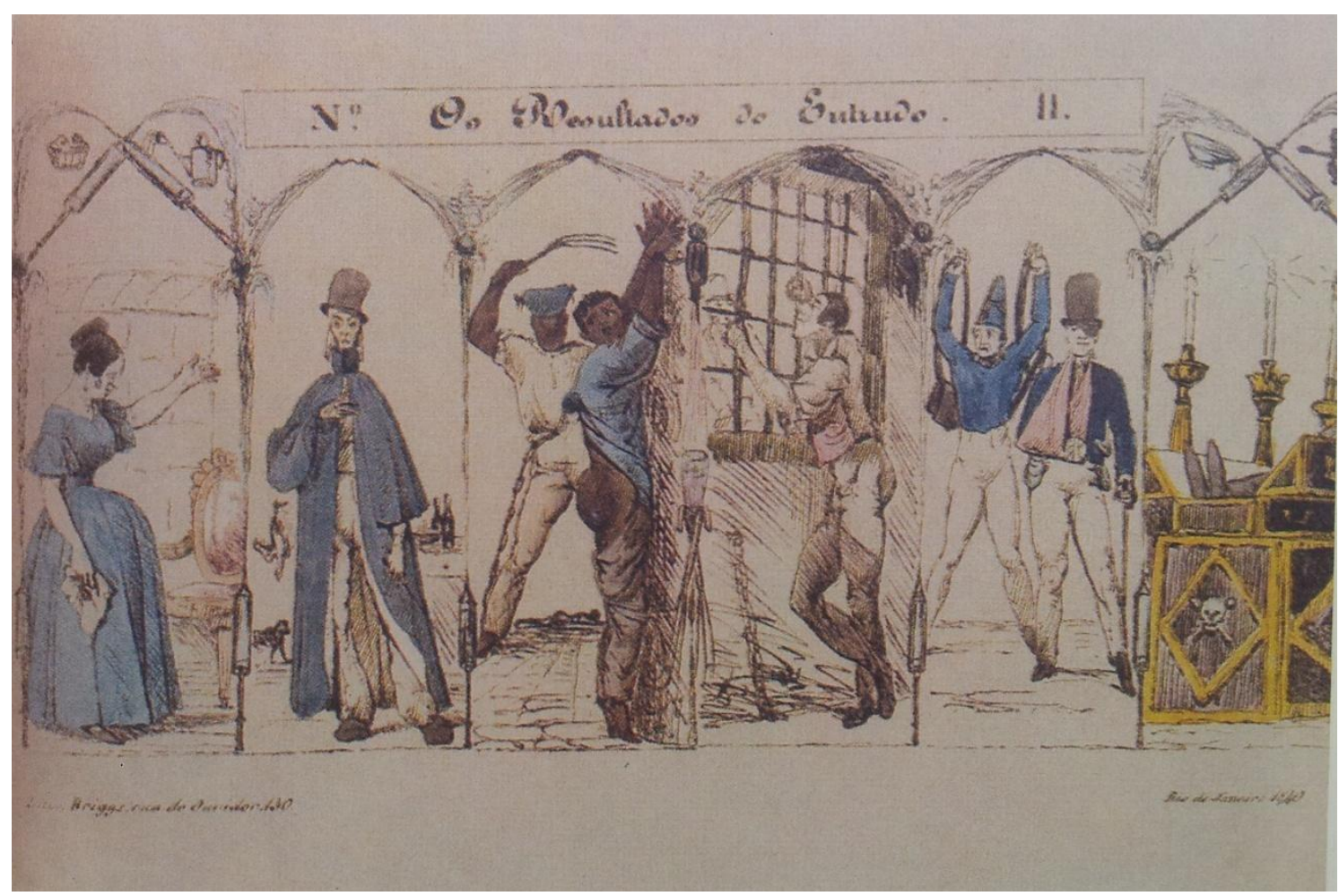

Figura 2

O salão hipoteticamente protegia seus convivas dos perigos e da violência da festa de rua, causada pela desmedida dos foliões anônimos. Essa noção, o Carnaval da Corte importou da Europa - mas mesmo lá, havia exceções.

Em 1832, vivendo em Paris como jornalista, correspondente da Gazette universelle d'Augsbourg e do Allgemeine Zeitung, Henrich Heine testemunhou o surto de coléra que acometeu a cidade em plena temporada de festejos carnavalescos, e escreveu sobre o pânico causado pela epidemia no diário de seus primeiros anos na capital francesa, publicado posteriormente em francês com o título "De la France". Conta o autor alemão a respeito da doença: “C'était um bourreau masqué, qui marchait

${ }^{413}$ MACEDO, 1988, p. 86. 
dans Paris, escorté d'une invisible guillotine ambulante." 414 Toda manhã, seu empregado doméstico lhe anunciava a lista de mortos do dia anterior, chamando sua atenção para o caso de algum conhecido ter sucumbido, e depois, suspirando, dizia: "Nous serons mis tous l'un après l'autre dans le sac!" - o que não era absolutamente uma figura de linguagem: "les cercueils manquèrent bientôt, et la plus grande partie des morts furent enterrés dans des sacs." O poeta se recorda de observar os sacos de tecido branco sendo empilhados diante de um edifício, indiscriminadamente, e depois sendo colocados em charretes que os levariam às valas: "Je me rappelle que deux petits enfants, à mine affligée, regardaient em même temps que moi, et que l'um d'eux me demanda si je ne pouvais lui dire dans quel sac était son père."

A irrupção do cólera naqueles meses foi, provavelmente, o que de mais próximo à Peste Negra viveu o século XIX. O mal que "sans égard pour le rang ni pour l'opinion, abat par milles ses victimes", chocava a todos pela aparência horrível dos acometidos. É certo que, antes de sua chegada, segundo Heine, a população recebia notícias da doença em Londres, onde não fizera muitas vítimas e, por isso, não se esperava que fosse tão feroz em Paris. Quando chegou, em 29 de março de 1832, era o dia da festa de "Mi-Carême", comemoração tipicamente francesa que assinalava a metade da Quaresma - um tipo de Carnaval fora de época. Fazia tempo bom, de acordo com Heine, e os parisienses passeavam animadamente pelos bulevares portando suas máscaras, entre elas, algumas que parodiavam a aparência dos infectados de cólera, com sua "couleur maladive et figure defaite, raillaient la crainte et la maladie elle-même”. Naquele mesmo dia, no fim da tarde, os bailes estavam lotados de foliões.

Les bals furent plus fréquentés que jamais; les rires les plus présompteux couvraient presque la musique éclatante; on s'échauffait beaucoup au chahud, danse peu équivoque; on engloutissait à cette occasion toutes sortes de glaces et de boissons froides

\footnotetext{
${ }^{414}$ HEINE, 1873, p. 131.

${ }^{415}$ HEINE, 1873, p. 132.
} 
isto é, ainda que fazendo troça do contágio, a impressão era de que esse sentimento mascarava o pânico coletivo - denunciado pelos risos escandalosos, mais altos que a música, pela coreografia desenfreada e excêntrica do chahud $^{416}$, pela glutonaria.

O relato, a partir daí, se torna tétrico: "tout à coup le plus sémillant des arlequins sentit trop de fraîcheur dans ses jambes, ôta son masque et découvrit à l'étonnement de tout ce monde um visage bleu violet." Quando tiram a máscara e revelam o contágio, o pavor se espalha rapidamente entre os presentes: ${ }^{417}$ “on s'aperçut tout d'abord que ce n'était pas une plaisanterie, et les rires se turent, et l'on conduisit bientôt plusieurs voitures de masques du bal immédiatement à l'Hôtel-Dieu, hôpital central où, em arrivant sous leurs burlesques déguisements, le plus grand nombre moururent." Esses primeiros mortos, vítimas do cólera e do terror do povo, foram enterrados tão apressadamente que portavam ainda suas coloridas fantasias.

A epidemia progride. Em 10 de abril, já se contabilizavam 2 mil mortos apenas nesse dia - e a população acreditava que o número era ainda maior do que os anúncios tentavam fazer acreditar. "Mon barbier me raconta - prossegue Heine - qu'une vieille femme était restée toute la nuit à la fenêtre, dans le faubourg Montmartre, pour compter les cercueils qu'on faisait passer devant sa maison, et qu'elle en avait vu trois cents; puis, quando vint le jour, saisie par le froid et par les douleurs du choléra, ellemême expira." 418 A continuação da narrativa se assemelha muito a de outros flagelos: cadáveres apodrecidos amontoados pelas vias, falta de carroças para levá-los às fossas que enchem muito rapidamente, enterros solitários e anônimos, os sobreviventes trancafiados em suas casas.

A verdade é que "le grand mal", ${ }^{419}$ como Heine chama o cólera, não chegou nem perto da Peste Negra em termos de número de vítimas. Nesse surto de 1831 a 1837 , a mortalidade foi de 2,4\% da população parisiense, $1,5 \%$ da população em Moscou; 0,4\% em Londres; Marseille 2,2\%; Lille 1\%; 5\% em Gênes, Veneza e Trieste 5\% cada; Nápoles mais de 5\%, Palermo de 10 a $15 \%$ e, o mais alto índice, na Catania e em

\footnotetext{
${ }^{416}$ Segundo o relato de Heine, dançava-se o chahud ou chahut - trata-se de outra designação para o can-can.

${ }^{417}$ A semelhança com o conto de Edgar A. Poe é inegável. Mais à frente, Heine comenta que, ainda que o cólera atingisse "avec une préférence visible" a classe mais pobre, os ricos não deixaram de fugir e que uma boa parte da haute finance igualmente deixou a cidade e foi viver em seus castelos - tal como a corte do príncipe Próspero em The masque of the red death. (HEINE, 1873, p. 143-144.)

${ }^{418}$ HEINE, 1873, p. 148.

${ }^{419}$ HEINE, 1873, p. 152.
} 
Siracusa, por volta de 20\%. No entanto, "il devient l'image, ou le masque, de la mort", segundo Michel Vovelle. A forte comoção relembrava as agressões da peste: uma doença que se acompanha a progressão territorial e se espera a chegada, que suscita a fuga em massa e, aos que ficam, o armazenamento de provisões, o fervor religioso, o desespero. Novamente, a iconografia macabra é evocada como metáfora para a situação: “Cette irruption de la mort au milieu de la vie, retrouve, dans l'iconographie du temps, les traits de la danse macabre., 420

Essa mesma imagem da avassaladora mortandade irrompendo em meio à alegria carnavalesca também se produziu no Brasil. De acordo com Luiz Felipe de Alencastro, "ao longo do século XIX, quem dançava no Rio em fevereiro e março era a morte, a Grande Ceifeira." 421 Isso porque, além da violência causada pelos excessos carnavalescos, o período era de chuvas frequentes, que traziam consigo surtos de febre amarela, cólera e varíola, além de outras viroses típicas do clima e da época do ano. Em um gráfico apresentado na História da vida privada no Brasil, vê-se que no ano de 1857, o total de enterros ocorridos no Rio de Janeiro sobe de 800 em janeiro para mais de 1200 nos dois meses seguintes ("consequência das febres contraídas durante as chuvas de verão", diz a legenda ${ }^{422}$ ), voltando a cair em abril e normalizando-se em maio e junho, na faixa dos 500. O fenômeno não estava restrito a capital do Império e verificou-se também na Bahia e no Recife. "Todas as províncias acabaram sendo atingidas por essas pestilências e mortandades." 423

O dado se repetia com regularidade. Angelo Agostini representou uma dessa ocasiões de "Triunfo da morte" para a Revista Ilustrada em uma gravura intitulada "O Carnaval de 1876". Em forma de um gigante e assustador esqueleto coberto com mortalha segurando uma foice descomunal, a Morte paira sobre a multidão, com seus carros alegóricos, bandeirolas e músicos. A gente, alegre e em regozijo, nem se dá conta do mal que a espreita. Em sua túnica, a impiedosa traz escrito seu nome: Febre Amarela. No arco que serve de moldura à imagem, de um lado vemos uma charrete conduzindo um folião; no centro, uma caveira mascarada é ladeada por garrafas de vinho (simbolizando, provavelmente, o excesso que leva à destruição); do lado oposto, à

\footnotetext{
${ }^{420}$ VOVELLE, 1983, p. 517-519.

${ }^{421}$ ALENCASTRO, In: NOVAIS e ALENCASTRO, 1997, p. 67.

${ }^{422}$ ALENCASTRO, In: NOVAIS e ALENCASTRO, 1997, p. 68.

${ }^{423}$ ALENCASTRO, In: NOVAIS e ALENCASTRO, 1997, p. 68.
} 
direita, um veículo mortuário carrega um caixão (Figura 3). A despeito de ilustrar a folia do carnaval de rua, é a Morte sua indubitável protagonista. É ela a dona da festa.

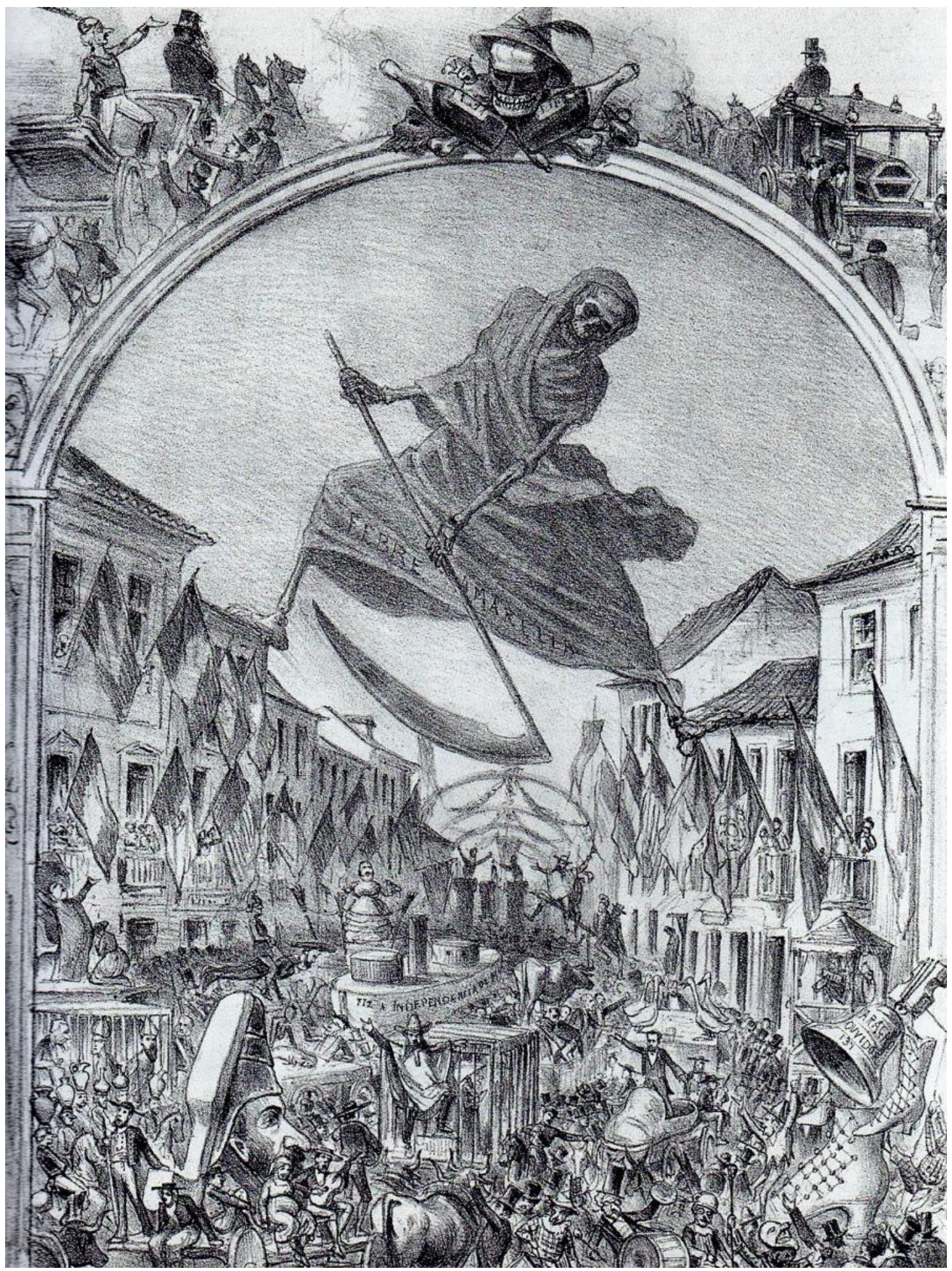

Figura 3 


\section{A macabra orgia da dança dos duendes}

Todo en furiosa armonía, todo en frenético estruendo, todo en confuso trastorno, todo mezclado y diverso.

Espronceda, El estudiante de Salamanca, 1840.

Os cadáveres da imaginação macabra sabem se entreter. Voltam à superfície para dançar, invadem inadvertidamente as festas dos vivos e se tornam seus protagonistas. Na inversão carnavalesca do mundo, eles promovem sua própria diversão: ao som do badalar da meia-noite, sob a luz da lua, rompem as campas e erguem-se sobre a terra. Preparam banquetes, afinam seus instrumentos. O sinal é dado e a música explode, penetrando os ossos gelados de seus esqueletos. Formam a grande ciranda de rodopio vertiginoso na qual os corpos corroídos se confundem em movimentos libidinosos. Desaparecem de súbito, sem deixar rastros - a não ser a nítida sensação de que a qualquer momento retornarão.

A essa altura, está claro que a descrição remete às danças dos mortos. Vimos, até aqui, sua origem no contexto da formação do conceito de macabro, na Idade Média tardia, assim como sua apropriação pelo Romantismo europeu, que lhe forneceu novos elementos e significados.

Mesmo com o profundo impacto das danças macabras na sensibilidade romântica do velho continente, é no Brasil que encontraremos um de seus mais preciosos exemplares: o poema A orgia dos duendes, do escritor mineiro Bernardo Guimarães, publicado em 1865. Nele, aparecem os componentes mais característicos da festim dos cadáveres: não despudoradamente copiados do modelo estrangeiro, mas misturados e adaptados à linguagem e aos elementos da cultura local.

A despeito de sua importância para o nosso tema, os versos da Orgia demoraram quase uma década para chamarem a atenção dos críticos. Desde seu lançamento em Poesias, o poema ficou relegado quase ao esquecimento, juntamente com a parte da 
obra poética de Bernardo Guimarães considerada marginal, "irregular" - assim a denominou Antonio Candido.

Bernardo, na verdade, nunca foi tratado como um autor de primeira grandeza em nosso romantismo. $\mathrm{O}$ cânone tradicional lembra-se dele principalmente por sua imensa popularidade como romancista (é autor de A escrava Isaura e $O$ seminarista - entre outro títulos - reeditados inúmeras vezes, sucesso de público desde seu lançamento) e por alguns poucos poemas que se destacaram como representantes da vertente mal $d u$ siècle, transbordando melancolia, como $O$ devanear do cético e as Evocações - essas, preferidas de um crítico influente como foi Silvio Romero. ${ }^{424}$ Foi também celebrado como um dos introdutores do regionalismo em nossa literatura. ${ }^{425}$

Ainda que fosse merecedor dos louros, era tido como romancista medíocre e poeta epígono, à sombra de Álvarez de Azevedo, seu colega na faculdade de direito de São Paulo. Seu nome estampa, via de regra, os últimos parágrafos dos capítulos didáticos sobre a "segunda geração romântica".

Se nem sua produção oficial era bem avaliada, imagine-se a parcela marginal. Formada por poemas de cunho humorístico, bestialógico e pornográfico, foi vista até poucas décadas atrás, como obra de juventude, sem preocupação formal, feitas por um irresponsável estudante boêmio meramente para o riso dos colegas mais próximos. Ledo engano. Títulos como Dilúvio de papel, O nariz dos poetas, Eu vi dos pólos o gigante alado, Elixir do pajé e A origem do mênstruo, entre outros, provaram possuir densidade estética e literária igual ou maior que os poemas ditos sérios e as novelas sentimentalóides do autor mineiro - a ponto de serem, hoje em dia, as mais conhecidas e procuradas de seu estro. A orgia dos duendes faz parte desse conjunto.

\footnotetext{
${ }^{424}$ Em História da literatura brasileira (1888), o crítico declara que ler as Evocações sempre lhe desperta "sincera emoção": "para mim, aquilo é a poesia verdadeira, feita com as lágrimas da realidade, com as desilusões da vida. Não transcrevo nada para não correr o risco de trasncrever quase tudo". (ROMERO, 1960, p. 983.)

${ }^{425}$ Segundo Silvio Romero, o que distingue a obra de Bernardo dos outros escritores de sua época são "as tintas sertanejas de sua paleta e o tom brasileiríssimo de sua língua" (ROMERO, 1960, p. 977). Para José Veríssimo, "Bernardo Guimarães é o criador do romance sertanejo e regional, sob seu puro aspecto brasileiro." (1969, p. 194). Dilermando Cruz: "Nunca existiu no Brasil um romancista mais brasielrio do que Bernardo, e em Minas nenhum outro tao mineiro." (1914, p. 154) Agrippino Grieco: "Foi elle nosso primeiro sertanista (...) compreende a alma vegetal da gente da roça." (1932, p. 41) Alfredo Bosi, ao falar do caráter híbrido de sua novelísitica sertaneja, o chama de "primeiro representante de mérito."(1970, p. 160)
} 


\section{A redescoberta da obra bernardiana pela via humorística}

Cabe nos atermos por alguns instantes nessa digressão. A revalorização da obra irregular de Bernardo mudou sua posição no cânone e trouxe consigo as primeiras leituras atentas do poema dos duendes. Vejamos como se deu esse processo.

Seu iniciador foi, indubitavelmente, Haroldo de Campos. Em ensaio publicado em 1969, Poesia sincrônica, o crítico foi categórico: era preciso mudar a maneira de abordar o fenômeno literário. Reconhecer as características de um movimento e encaixar ou menosprezar os autores de sua época que desenvolveram-nas mais ou menos, melhor ou pior, era a forma mais antiguada de se fazer crítica literária. Às vezes, é na produção que diverge do padrão estilístico em que geralmente são incluídos que certos autores deveriam ser valorizados. Seu papel na história da literatura certamente mudaria.

“O primeiro passo para a revisão em profundidade de nosso passado poético seria, a meu ver, uma 'Antologia da Poesia Brasileira da Invenção', onde os autores selecionados o fossem por uma contribuição definida para a renovação das formas em nossa poesia (...)." 426 Por esse novo viés, os usuais rótulos de "poetas maiores" e “poetas menores” receberiam "o tratamento que se dá às inutilidades. ",27

Campos não chega a desenvolver sua proposição, mas ao colocar Bernardo Guimarães entre os autores que deveriam ser revistos - através do que chamou de "uma perspectiva sincrônica"- justamente por seus poemas pouco conhecidos, trouxe a lume o lado obscurecido do poeta mineiro. Se, por um lado, Bernardo foi um "romancista mediocre”, por outro, Campos o considera "um precurssor do Surrealismo”: “o que nos interessa hoje de seu acervo é a parte burlesca, satírica, de "bestialógico" e "nonsense", de seu estro poético." Os poemas destacados no artigo foram Eu vi dos pólos o gigante alado e A orgia dos duendes.

A recomendação de Haroldo de Campos foi essencial para essa redescoberta. Uma mudança no approach à obra bernardiana se delineava, que deixava de lado o

${ }^{426}$ CAMPOS, 2010, p. 208.
${ }^{427}$ CAMPOS, 2010, p. 209. 
romancista e atentava ao poeta cômico. Mas qual era o paradeiro de seus versos humorísticos?

A maior parte deles foi publicada em Poesias, de 1865. No caso dos versos pornográficos (Elixir do pajé e Orgiem do mênstruo), o rastreamento é mais difícil. A primeira aparição do Elixir parece ter sido uma impressão anônima simplória, em papel de má qualidade, datada de 7 de maio de 1875, feita em Ouro Preto - diz-se que outras edições clandestinas também circularam - com o consentimento do autor:

É voz corrente que na época, na província de Minas Gerais, corriam cópias volantes do Elixir do pajé assiandas por "B.G.", e que Bernardo Guimarães, ao ser interpelado na rua pelo padre local, que condenava veementemente esse procediemnto imoral do poeta, teria se defendido dizendo não ser ele o autor do discutido poema. O padre, não satisfeito, questionou: "Quem poderia ser "B.G." se não o senhor, doutor Bernardo?" Bernardo cinicamente fitou o padre e fulminou: "Que eu saiba, é o Beato Gregório." 428

José Maria Vaz Pinto Coelho, o organizador do primeiro compêndio póstumo das obras de Bernardo, Poesias e romances do Dr. Bernardo Guimarães, de 1885, relatava que:

para desespero do Sr. B. L. Garnier, editor de todos ou quase todos os livros de Bernardo Guimarães, o escripto mais popular do autor dos Cantos da Solidão é um poemeto obsceno intitulado "O elixir do pagé", que nunca foi impresso! É raro o mineiro que não o saiba de cór. Há na província espalhadas um sem número de cópias de "Elixir" inútil e brejeiro. ${ }^{429}$

Ou seja, os versos obscenos, sabidos "de cór", eram até mais famosos que sua poesia "séria". Apesar do gosto popular, a incursão no erotismo de linguajar calão era lamentada, como se percebe pela qualificação do poema do pajé: "inútil e brejeiro".

${ }^{428}$ LIMA, 2000, p. 85.

${ }^{429}$ COELHO, 1885, p. 223. 
Foi justamente na coletânea das obras de Bernardo organizada por José Coelho que ele viria oficialmente ao público, junto de A origem do mênstruo. Depois de ter agrupado as peças humorísticas mais leves em uma seção denominada "Produções pantagruélicas e bocageanas do Dr. Bernardo Guimarães”, os famigerados poemas mordazes são deixados para o final - precedidos por uma "Advertência importante", dirigida a "adolescentes de um e outro sexo", em que se lê: "Não são para vós as páginas que se seguem. Se as abrisseis depois deste pregão, só de vós mesmos vos poderieis queixar. "430 O recado dado por pouco é desnecessário: os poemas são tão censurados, tantas palavras são trocadas por reticências e tantas linhas inteiras são pontilhadas, que ficaram quase incompreensíveis.

Só na década de 1950 é que os poemas seriam mostrados em todo seu esplendor pornográfico: em 1951 pela editora belo-horizontina Movimento Editorial Panorama e em 1958, pela carioca Piraquê. Finalmente, em 1988, ao célebre duo foi adicionada $A$ orgia dos duendes e os três poemas foram publicados na íntegra em 1988, pela editora Dubolso, de Minas Gerais - e, novamente, em 1992, pela Imago, com organização de Duda Machado. Na ocasião, Machado escreveria um juízo que marcaria o redescobrimento desses versos subestimados: "é preciso dizer que sua poesia satírica é a mais consistente e divertida crítica que se poderia ter das debilidades literárias do romantismo brasileiro. "431 Daí em diante, como o interesse acadêmico pela produção marginal de Bernardo aumentava exponecialmente, outras publicações acontecem (como em 2004, na Antologia ponográfica: de Gregório de Mattos a Glauco Mattoso, de Alexei Bueno). Hoje em dia, qualquer obra sua é facilmente encontrada na Internet.

Nos mesmo anos 1950 que tiveram ciência da faceta obscena de Bernardo, foi publicada a Biografia crítica das letras mineiras, por Waltensir Dutras e Fausto Cunha (1956). Ela ilustra bem a mudança de perspectiva sobre a obra de B.G.: seu nome entra no tópico "A poesia satírica no século XIX”. O que primeiramente se diz dele é a respeito de seus bestialógicos e de suas sátiras "às modas", como em Saia Balão. Na continuação, lembram sua atuação como crítico do jornal carioca $A$ atualidade, entre 1859 e 1860 - que reclamam esquecida, quando mereceria maior destaque:

\footnotetext{
${ }^{430}$ COELHO, 1885, p. 201.

${ }^{431}$ MACHADO, 1992, p. 22.
} 
É preciso que se acentue, para os que não as conhecem [as críticas de B.G.], que não se trata dos costumeiros artigos laudatórios da época, de divagações mais ou menos frívolas, e sim de crítica literária no sentido mais rigoroso da expressão. Não uma crítica circunstancial, mas uma crítica objetiva, de importância fundamental para o exame da obra de Bernardo Guimarães e indispensável a um seu estudo no Brasil. ${ }^{432}$

Cunha e Dutra deixam para tratar do romancista e do poeta sério por último, invertendo a ordem analítica do cânone oficial ao abordar a produção bernardiana. Exaltam justamente aquilo que a historiografia deixava de canto, diminuindo ou mesmo fingindo não existir - o poeta satírico e o crítico.

A grande reviravolta ganharia contornos ainda mais surpreendentes com Antonio Candido. Em Formação da Literatura Brasileira, de 1959, o historiador não apenas dedica um capítulo inteiro à B.G. como oferece grande espaço desse texto à leitura da Orgia dos duendes - é o poema mais comentado. Em uma abordagem de cunho mais psicológico, Cândido, ao contrário da maior parte da crítica, não considera os Cantos da solidão (seu primeiro volume publicado) sua melhor obra, mas sim, Poesias diversas, seu segundo livro, "quando domesticou melhor o impulso por vezes desordenado dos Cantos." E novamente divergindo da crítica, percebe o traço ultra-romântico do exílio e da solidão não nos versos melancólicos, mas na descrição da natureza, no movimento para dentro do país. O regionalismo de Bernardo seria, para Cândido, uma maneira de associar a experiência afetiva à experiência dos lugares - "nele se trata mais de isolamento, de segregação física em relação ao semelhante, para reequilibrar-se ao contacto da natureza. ${ }^{433}$ Elogia sua veia humorística, na qual distingue três níveis: poemas leves "em que a graça e o devaneio equilibram o humor", como Ao charuto e Minha rede. Depois, o de temas impessoais e intenção satírica ( $O$ nariz perante os poetas, Delírio de papel e A saia balão). O bestialógico, "gênero em que brilhou, produzindo peças da melhor qualidade”, citando os Disparates rimados e Eu vi dos pólos o gigante alado. Finalmente, a poesia obscena, "em que o humorismo vai-se carregando de intenções obscuras até tocar no sadismo." Os poemas do pagé, do mênstruo e dos duendes são seus representantes.

\footnotetext{
${ }^{432}$ CUNHA \& DUTRA, 1956, p. 50-1.

${ }^{433}$ CANDIDO, 1975, p. 173.
} 
Tamanha atenção dada por Cândido à produção irregular de Bernardo era inédita. Talvez tenha contribuído para a inserção da Orgia na antologia Poesia romântica, organizada por Péricles Eugênio da Silva Ramos, em 1965 - era a primeira vez que o poema aparecia em um compêndio dedicado à escola.

Anos mais tarde, no ensaio A poesia pantagruélica, de 1993, Cândido iria além. Afirma que o bestialógico dos românticos brasileiros, com destaque para o de Bernardo, "mostra uma face de modernidade, inclusive porque tem muitos de associação livre, que, no século XX seria proclamada método revelador pelo Dadaísmo e o Surrealismo"- legitimando o veredito de Haroldo de Campos. Os versos de aparente nonsense e absurdo, sempre considerados a recreação inocente de universitários entediados, não deveriam ser encarados apenas do ângulo da comicidade, que é um de seus aspectos; há neles "a semente de pesquisas futuras e o desejo de desrecalque, de tocar nos mecanismos profundos, que o Romantismo sugeriu no limiar do mundo contemporâneo. ${ }^{434}$ A produção menosprezada de B.G., vista até então como despretensiosa ou de pouco valor literário, revelava-se, gradativamente, de grande profundidade.

Algumas pequenas pistas desta possibilidade já haviam sido dadas anteriormente, mas de maneira tão vaga que passaram despercebidas. José Veríssimo, no começo do século XX, havia sugerido, muito rapidamente, a hipótese de que o "verdadeiro" poeta estivesse por trás das "poesias alegres", nas quais teria revelado sua personalidade mais do que nos poemas ou na prosa canônicas, sendo "o mais espirituoso, o mais engraçado e, excluindo Gregório de Matos, o único humorístico dos poetas brasileiros."435 Agrippino Grieco, na década de 1930, disse algo muito semelhante (porém, sem desenvolver o comentário): "os versos sobre o charuto e a saia-balão são saborosíssimos, e os próprios versos obscenos sobre o velho pagé, paródia de G.Dias, divertem a valer, sendo talvez, no gênero, os melhores da língua, exceputados, naturalmente, os de Bocage. ${ }^{, 436}$ Péricles Eugênio da Silva Ramos, em Do barroco ao Modernismo, em 1979, relembra as histórias da Sociedade Epicuréia e, enfatizando o repertório byroniano do poeta, emparelha o Devanear de um céptico à

\footnotetext{
${ }^{434}$ CANDIDO, 2004, p. 199.

435 VERÍSSIMO, 1977, p. 146.

${ }^{436}$ GRIECO, 1932, p. 41.
} 
Orgia dos duendes, afirmando-a "um dos documentos mais notáveis" da segunda geração romântica. $^{437}$

O golpe de misericórdia no poeta sério, em favor do poeta satírico, veio de Wilson Martis (na História da inteligência brasileira, de 1977):

nos Cantos da solidão, mais do que o jovem romântico voltado para o futuro e coribanticamente dominado pelas paixões, Bernardo Guimarães é, a essa altura, um filintista retardado e frio, correto e laborioso, escrevendo poesias como um dever escolar, apenas porque era o que então se fazia entre os estudantes. O seu caso é, em poesia, exatamente o que foi de Martins Pena no teatro e o de Macedo na prosa de ficção, todos contrariando as suas espontâneas e nativas inclinações humorísticas (em que eram insuperáveis) em favor do melodrama sentimental que então monopolizava o gosto do grande público. ${ }^{438}$

Massaud Moisés, em 1983, retoma o mesmo juízo: desconsiderando sua lírica ultra-romântica e chamando-lhe de "fingimento elaborado sobre clichês ou intuições alheias", enaltece, na trilha seguida por Candido, seus bestialógicos como precurssores da poética Surrealista. ${ }^{439}$ E cita trechos da "insólita” Orgia dos duendes, que "parece antever o clima antropofágico de 1922", 440

Mas é no ano seguinte, 1984, que apareceria um dos artigos fundamentais à releitura da obra bernardiana. Trata-se de Bernardo Guimarães: Romantismo com péde-cabra, de Flora Sussekind. Por ocasião do centenário da morte do autor (que, segundo, ela, “vai passando em branco”), Flora denuncia a crítica tradicional que, ora jogava para escanteio a participação de Bernardo na história literária (agrupado junto aos "epígonos", tendo seu papel de autor secundário mais do que consolidado), ora é encarado como "figura singular", em que se avalia seus escritos associando-os à sua biografia, frequentemente romantizada e falseada. Estudante boêmio entregue à devassidão e aos vícios, juiz irresponsável, crítico intolerante, professor faltoso, etc,

\footnotetext{
${ }^{437}$ RAMOS, 1979, p. 74.

${ }^{438}$ MARTINS, 1977, p. 463.

439 “ o próprio Surrealismo parece iniciar sua demorada gênese nos festins em que a poesia bestialógica, ou pantagruélica, jorrando das profundezas do subconsciente ainda mal desperto, se destinava ao riso estúrdio e às fugas sem retorno." (MOISÉS, 1983, p. 139)

${ }^{440}$ MOISÉS, 1983, p. 185.
} 
"sempre às voltas com episódios cômicos e demissões", sua vida se transformou numa saga livresca que se relacionaria diretamente com o que saía de sua pena. Perdia-se, assim, a riqueza de suas experimentações e a densidade dos versos, encobertos pelo comportamento do autor.

\begin{abstract}
Uma crítica que se traveste de biografia. Biografia que se converte numa sucessao de casos engraçados. Esta, a fortuna crítica de Bernardo Guimarães. Como se o poeta fosse o livro a ser aberto, é apenas nele e nas suas idiossincrasias que se buscam em geral as chaves interpretativas da obra. Daí, para uma poesia crítico-humorística, buscarem-se explicações em anedotas biográficas. Estudantas? Orgias com leprosas em São Paulo? As consequências poéticas seriam textos como A orgia dos duendes ou $O$ elixir do paje. ${ }^{441}$
\end{abstract}

O artigo de Sussekind tornou-se um verdadeiro chamariz para a produção ignorada de B.G., que afirma, ao final, ser, "uma das melhores e mais características obras poéticas do Romantismo” , “dotada de dimensão crítico-humorística incomum em meio aos indianismos, arroubos de eloquência e subjetividades lacrimenjantes", não obstante, "por sua diferença”, ter alcançado "limitada repercussão." 442 Luiz Costa Lima, em ensaio escrito em 1987, fala justamente desses dois Bernardos criados pelo cânone conservador da segunda metade do século XIX, representado por Romero e Veríssimo acima de todos: o Bernardo legitimado e o Bernardo excluído - o primeiro, autor dos vários romances regionalistas ou de fundo histórico e poeta de inúmeras peças de homenagens e versos insignificantes (que, bons ou ruins, nunca encontraram seu lugar no Romantismo normatizado, pois eram considerados de perfil neoclássico); o segundo, o do humor. Agredindo assumidamente ou não o modelo vigente, esse outro Bernardo ironizava os lugares-comuns caros ao cânone, por isso, ficava fora dele. ${ }^{443}$

\footnotetext{
${ }^{441}$ SUSSEKIND, 1993, p. 142.
}

Para se ter uma idéia de como essas eram impressões já estabelecidas, Pires de Almeida, em obra de grande repercussão (A escola byroneana no Brasil, 1962) afirma que na vida madura Bernardo teria contraído um perigoso vício em éter, que não só inalava como ingeria. A história foi replicada inúmera vezes. Ubiratan Machado, declara, então, baseado não se sabe em quê, que Bernardo compôs A orgia dos duendes sob efeito do narcótico(!) No entanto, a informação sobre o uso do éter não consta em nenhum de seus biógrafos, como Basílio de Magalhães e Armelim Guimarães, nem no relato do amigo íntimo, Carlos José Santos.

${ }^{442}$ SUSSEKIND, 1993, p. 150.

${ }^{443} \mathrm{O}$ ensaio de Lima vai além na discussão do cânone estabelecido a partir de meados do século XIX. Produto de uma consolidada sociedade burguesa que via na literatura um instrumento de difusão de seus valores conservadores, nada que infringisse sua moral seria bem-vindo ao padrão literário em formação. 
Daí o porquê de Paulo Franchetti afirmar, em $O$ riso romântico: notas sobre o cômico na poesia de Bernardo Guimarães e seus contemporâneos, de 1987, que, se não fossem seus bestialógicos, a Orgia dos duendes e os poemas fesceninos, Bernardo Guimarães seria apenas mais um "poeta mediocre." 444 O estudioso advoga pela recuperação das obras cômicas feitas pelo nosso Romantismo como um todo, mas a novidade trazida em seu ensaio refere-se, de certa maneira, à valorização do fator biográfico - não aquele personalista e dado a extravagâncias, depreciado por Sussekind, um de outra ordem.

Para se entender o impacto dessa produção satírica era necessário, de acordo com Franchetti, observá-la no contexto em que ela se formou: "a vida boêmia, a emulação diária de poetas que se conheciam e conviviam estreitamente no quotidiano das pequenas cidades de meados do século passado, pois dela provinha o estímulo mais importante para essa criação satírica e cômica. "445 Escrevendo para seus iguais, os jovens poetas acadêmicos encontravam um público de alto nível intelectual - se comparado ao grande público ao qual eram destinados os textos que convinham mais à sua leitura, como os romances e a poesia sentimental, que agradariam (ou, pelo menos, não ofenderiam) sua concepções morais e políticas. Entre os estudantes, a atmosfera de grande camaradagem "propiciava uma suspensão do juizo moral sobre os textos" e "estimulava um certo inconformismo político", nem sempre compatível com as funções que os futuros bachareis assumiriam na sociedade. ${ }^{446}$

Disso resulta que, no caso de Bernardo, as poesias feitas ainda sob influência do ambiente boêmio estudantil (do qual ele nunca se afastou completamente - vide os relatos de seu amigo Carlos José Santos e o de seu biógrafo oficial, Basílio de Magalhães ${ }^{447}$ ) mantivessem o aspecto libertador e inventivo dos bestialógicos

Daí a escolha daquilo que estivesse em consonância com esse conjunto de valores: a idealização da mulher (ou sua demonização, quando apresentasse comportamento indesejável), discursos lacrimosos e enaltecedores das instituições, narrativas sentimentalóides que ensinavam princípios, etc, em detrimento de obras originais - independente do aspecto dessa originalidade. A produção pornográfica de Bernardo, ao lado da humorística que satirizava o modelo neoclássico ou romântico, foi, nesse sentido, sumariamente ignorada, a despeito de sua qualidade. $\mathrm{O}$ autor ainda chama a atenção para a dificuldade, mesmo hoje, em se desvincilhar do cânone vitoriano, não apenas porque em larga medida a sociedade vive sob a égide dos mesmo valores oitocentistas, mas porque o discurso canônico já é tão estabelecido que o estudante ou pesquisador se vê sem motivação para questioná-lo. (LIMA, 1991, p. 241 - 252)

${ }^{444}$ FRANCHETTI, 1987, p. 8.

${ }^{445}$ FRANCHETTI, 1987, p. 15.

${ }^{446}$ FRANCHETTI, 1987, p. 15.

${ }^{447} \mathrm{O}$ primeiro foi professor no Liceu Mineiro, em Ouro Preto, na mesma época que Bernardo Guimarães assumiu a cadeira de Retórica da instituição. Os dois chegaram a morar juntos numa residência ocupada 
improvisados, do satanismo adolescente, da pornografia escatológica. Quando esse espírito arrefeceu, o poeta dedicou-se aos romances melosos, à poesia banal.

Sua grandeza provém do outro lado, da força com que ele manteve viva, ao longo de vários anos, aquela face obscura de toda uma geração. Aquela energia, agressividade, criatividade e não-conformismo juvenis que, embora subterrânea e marginalmente, nele puderam encontrar a melhor e mais completa realização. ${ }^{448}$

Essa mesma premissa nortearia Riso entre pares (1997), consistente estudo de Vagner Camilo sobre o humor romântico. O enfoque é o vínculo entre as formas humorísticas praticadas e o meio em que eram produzidas, a boêmia estudantil paulistana, que servia não apenas de estímulo para essa produção, mas era também seu destino final. A pesquisa de Camilo se limita (com intento de analisá-la pormenorizadamente) à ironia romântica de Álvares de Azevedo e ao bestialógico e ao obsceno de Bernardo Guimarães, dois nomes que considera representativos o suficiente para que as considerações sobre eles pudessem ser extendidas aos outros.

Camilo estabelece o diálogo entre a produção humorística de Álvares e Bernardo e seus pares, em geral, também poetas ("o 'conjunto de produtores' correspondia ao corpo acadêmico como um todo" 449 , ainda que muitos deles jamais compusessem uma estrofe sequer depois de formados). Por serem também os receptores diretos desses textos, feitos justamente para circulação interna entre o grupo, eram eles mesmos que opinavam, criticavam e fixavam a linguagem a ser utilizada por todos. Segundo Camilo, encontraram no romantismo a poética adequada, que se manifestou no nacionalismo indianista em menor grau e no sentimentalismo ultra-romântico e no satanismo em maior. Mas, acima de tudo, o que esse ambiente de mútuas contribuições proporcionava era uma profunda cumplicidade, "necessária para que o riso ecoe."450

por estudantes. Carlos José Santos conta que Bernardo confraternizava frequentemente com os jovens. (SANTOS, 1928). Basílio de Magalhães confirma o interesse de Bernardo pela vida acadêmica e pelos hábitos boêios dos universitários - dos quais nunca se livrou totalmente. (MAGALHÃES, 1926)

${ }^{448}$ FRANCHETTI, 1987, p. 16.

${ }^{449}$ CAMILO, 1997, p. 38.

${ }^{450}$ CAMILO, 1997, p. 40. O riso romântico aparecia sob a égide das três abordagens mencionada (nacionalismo indianista, sentimentalismo ultra-romântico, satanismo): nas paródias ao ideal indígena, 
Esse humor aí gerado era, por sua vez, de natureza antipoética, no sentido que implicava uma "ruptura com a expectativa média (patriótica ou sentimentalmente edulcorada) do leitor do tempo", ${ }^{451}$ ao qual não era dirigido. Era esse o cenário, por exemplo, da invenção dos bestialógicos, chamados pelos jovens poetas de poesia pantagruélica (e por Camilo de "variante local do nonsense verse",452), que Bernardo com maestria dominava. Para o crítico, era "a expressão mais acabada do grupo (...) onde o cômico se libera para a pura fantasia do grotesco verbal ${ }^{, 453} \mathrm{e}$ que, apesar da qualidade e da novidade (Camilo também vê neles a semente de métodos modernos de processos criativos) ficavam restritos à fruição apenas dos envolvidos.

A análise aprofundada do bestialógico, inclusive em abordagem psicanalítica, revelando seu aspecto liberador de demandas inconscientes recalcadas, foi uma das contribuições do estudo de Camilo para a reavaliação da obra irregular de B.G. Riso entre pares parece ser, ainda hoje, o livro que mais detalhadamente e com maior rigor, tratou desse conjunto. Ponto culminante do interesse suscitado pelos versos cômicos do poeta mineiro, denotava o esforço da crítica contemporânea não de ajustá-lo ao cânone, mas de lançar luz em obras que, pelo sistema canônico tradicional, seriam descartadas, a despeito de sua qualidade formal, temática, histórica.

Nessa leva de novos estudos dos quais se destacaram os de Sussekind, Costa Lima, Franchetti e Camilo, um dos saldos positivos é a merecida apreciação suscitada pela Orgia do duendes, alvo de leituras cada vez mais minuciosas. O que nos desperta a cautela, entretanto, é perceber que todas giram, mais ou menos, ao redor dos mesmos enfoques. Vejamos por que.

como em O elixir do pajé; no humor auto-depreciativo, que ri de si mesmo, ainda que no sentido de uma subjetividade melancólica, como os poemas dedicados ao charuto e ao cognac, de Álvares; e o satanismo como metáfora para o inconformismo e a sátira social e moral.

${ }^{451}$ CAMILO, 1997, p. 205.

${ }^{452}$ CAMILO, 1997, p. 100.

${ }^{453}$ CAMILO, 1997, p. 44. 


\section{Leituras da Orgia na tradição sabática e satanista}

Em 10 de outubro de 1865, escreveu o intelectual mineiro Sr. Ovídio J. P. de Andrade, no número 531 do periódico Minas Gerais, sobre o lançamento do volume Poesias do Dr. Bernardo J. da S. Guimarães. Elogia-lhe a "pasmosa flexibilidade" de seu talento estético: "inesperado e verdadeiramente épico no "Ermo" e "Devanear do Scéptico", faceto e jovial no "Charuto" e "Saia Balão”, phantastico na "Orgia dos duendes" e "Dilúvio de Papel", terno, lânguido e sentimental na maior parte de suas composições", nas quais, apesar da variedade, "reconhece-se sempre o mesmo homem, sua originalidade não se desmente nunca."

O Sr. Andrade teria ainda mais algumas palavras a dizer sobre A orgia dos duendes:

É uma poesia de gênero phantastico, gênero este muito cultivado na velha Alemanha, e que não tem ainda representante entre nós. A julgar-se por esta bella poesia, é o Dr. Bernardo Guimarães eminentemente próprio para tal especialidade, e fazse credor de elogio por ter introduzido um gênero novo em nossa literatura.

As creações phantasticas da superstição popular apresentão-se ahi embellezadas pela imaginação do poeta, e formão uma orgia infernal, um Sabbath monstruoso, em que danção, cantão, e são finalmente dispersas pela morte. ${ }^{454}$

Estão aí, na crítica desse desconhecido professor mineiro, desde já, estabelecidas as linhas interpretativas para o poema dos duendes. Trata-se, 1) de uma orgia infernal, o que o vincula à tradição do satanismo romântico; 2) de um sabá monstruoso. A despeito de ter sido ignorada por muito tempo, a Orgia, quando começou a ser mencionada, foi, salvo exceção, pelas mesmas abordagens.

Observem: Olavo Bilac, em 1912, em uma conferência sobre o diabo, credita-lhe o "registro de cerimônias da demonologia brasileira", e de "tradições sabáticas. "455 Para um dos principais responsáveis no resgate da obra irregular de Bernardo, Luiz

\footnotetext{
${ }^{454}$ A crítica, na íntegra, foi reproduzida em COELHO, 1885, p. 55- 63.

${ }^{455}$ Bilac apud MELLO e SOUZA, 1993, p. 181.
} 
Costa Lima, o poema é um "pandemônio fáustico em ritmo de arremedo gonçalvino." "456 José G. Merquior, no mínimo espaço que oferece ao poema, refere-se às suas "quadras infernais". ${ }^{457}$ Massaud Moisés o define como um "festival sabático de fortes raizes na cultura nativa". 458 "Poesia sabática, cheia de negros tons, de satanismo fáustico”, diz Péricles Eugênio Ramos; ${ }^{459}$ e Antonio Candido o resume da seguinte forma: "O poema descreve uma espécie de sabá, uma reunião de diabos, bruxas, feiticeiros transformados em animais e monstros do nosso populário. "460 Para Flora Sussekind, é uma Walpurgisnacht sertaneja, pertencente à produção de Bernardo inspirada por Satã. ${ }^{461}$ A influência da noite do Walpurgis do Fausto é também apontada por Lima ${ }^{462}$ e por Vagner Camilo, que entitula seu capítulo sobre o poema de "Walpurgisnacht e o Pandemonismo sertanejo". ${ }^{463}$ Duda Machado fala da orgia e "seu aspecto demoníaco”, enquanto Laura de Mello e Souza afirma categoricamente: "sem ser mencionado, é o sabá das bruxas a personagem central do poema de Bernardo Guimarães” e, ainda: "[a] 'Orgia dos duendes na verdade é orgia de bruxas." 464 Os juízos todos coincidem quanto à natureza do poema, e parecem consolidados.

Convém, nesse momento, nos voltarmos ao poema conforme foi lido por todos eles.

É meia-noite - anuncia o toque de um relógio de sino feito em madeira. Surge uma velha, identificada como a rainha da festa, que se acomoda sobre um jirau. De lá, ela inicia o chamamento que desperta os mais diversos seres até então escondidos, e os convida a se reunirem numa clareira no meio da floresta. É ela quem coordena os trabalhos, enquanto alguns personagens importantes se ocupam em acender uma grande fogueira, preparar o banquete e trazer os intrumentos musicais que animarão a madrugada.

Mas essa não é uma festa qualquer, é uma orgia de duendes, o que implica a presença de convivas sui generis: capetas com rabos de macaco; diabos vestidos de roxo; lagartixas de rabo vermelho; "raparigas do monte das cobras"; um sapo gordo

\footnotetext{
${ }^{456}$ CAMPOS, 2010, p. 211.

${ }^{457}$ MERQUIOR, 1977, 77.

${ }^{458}$ MOISÉS, 1985, p. 185.

${ }^{459}$ RAMOS, 1965, p. 138.

${ }^{460}$ CANDIDO, 2004, p. 209.

${ }^{461}$ SUSSEKIND, 1993, p. 148.

${ }^{462}$ CAMILO, 1997, p. 159.

${ }^{463}$ LIMA, 1991, p. 248.

${ }^{464}$ MELLO e SOUZA, 1993, p. 190-195.
} 
com chifres na testa; mil bruxas que chegam montadas em suas vassouras; mil duendes... Além desses, os protagonistas, figuras cuja natureza não se esclarece totalmente, identificados por termos pitorescos como Taturana, Getirana, Galo-Preto, Mula-sem-cabeça, Crocodilo, Lobisome (grafado assim, como um registro da oralidade), Esqueleto. Alguns desses nomes são explicados em um glossário anexado ao poema, e descobrimos que todos, com exceção do último, se referem à bichos, sejam lagartas, insetos ou espécies imaginárias do anedotário popular. Apesar da maneira como são chamados, presume-se que seriam os duendes do título.

A primeira parte do poema conta a chegada de todos esses convidados especiais, que respondem à invocação da velha. $\mathrm{Na}$ segunda parte, findam os preparativos, a música animada começa a ser tocada e o baile começa:

Já ressoam timbales e rufos, Ferve a dança do cateretê; Taturana, batendo os adufos, Sapateia cantando - o le rê!

E já nessa atmosfera de grande prazer e despudor, abre-se uma roda em volta do fogo. No ritmo de uma entusiasmada ciranda, os protagonistas, uma por vez, contam sobre suas vidas pregressas.

E dançando em redor da fogueira vão girando, girando sem fim; Cada qual uma estrofe agoureira Vão cantando alternados assim

Revela-se então que todos, em vida, foram membros de altas hierarquias, tanto eclesiásticas quantos seculares. E o mais terrível é que abusaram de seu poder humano para cometer as mais loucas atrocidades. Taturana foi iniciada nos gozos carnais pelo próprio pai, de que gerou um filho - e mesmo assim se tornou freira e morreu como santa. Concubina sacrílega de um abade e depois de um frade, Getirana matou dois maridos - e depois os dois clérigos - além de abortado alguns filhos por através de "artes" que conhecia, e que lhes caíram do ventre direto no túmulo.

Mula-sem-cabeça, uma bela e nobre condessa, também foi companheira sacrílega de um bispo. Seu marido descobriu e o matou. Como já estava enjoada do 
casamento, assassinou o cônjuge, o picou em pedaços e... bem, "E depois o comi aos bocados", ela conta. Acabou guilhotinada - daí, provavelmente, a escolha de seu nome. Galo-preto, Esqueleto e Crocodilo foram todos homens da Igreja. O primeiro, um frade que, mesmo vivendo em um convento, teve vida desregrada e libertina. O segundo, monge santificado depois de morto, foi um assassino sanguinário e pirofágico: “Quantos vivos queimei sobre a terra, / Já eu mesmo contá-los não sei.” Papa de poder incomensúravel, assim como sua devassidão, foi Crocodilo. E o impiedoso rei que fora Lobisome diverte-se com as proezas que cometeu:

Eu fui rei, e aos vassalos fiéis Por chalaça mandava enforcar; E sabia por modos cruéis As esposas e filhas roubar.

Finalmente, fala a Rainha, a mais feroz assassina dentro todos. Matricida ("minha mãe, ao nascer, eu matei”), parricida (o pai, “em seu leito co’as mãos esganei”), fratricida (o irmão, “c’uma pedra amarrada ao pescoço, / afogado no fundo de um poço"), assassinou três maridos - o primeiro, asfixiado; o segundo, empurrou do alto de uma torre; o terceiro, pelas costas, lhe cravou um punhal - e vários amantes. Não há crime que não tenha cometido quando a oportunidade lhe veio, e com requintes de malignidade.

Os relatos aumentam a excitação e a dança chega em seu momento máximo, de rodopio vertiginoso e "batuque infernal". É nesse instante que se avista no horizonte um vulto montado a cavalo: era a Morte, que surge de súbito, para espantar "a nojenta canalha". Tudo se apaga em um estalo e o desvairada grupo "sumiu-se de chofre".

Ao amanhecer, não se viam vestígios "da nefanda, asquerosa folia" que acontecera pouco tempo antes. Naquela mesma floresta, os passarinhos anunciavam o dia, "gorjeando sonoros queixumes", saltitando suavemente sobre as flores. Entre elas, uma jovem, linda virgem, “cismava de amores" e passeava sozinha e sem medo.

Por fim, um Glossário é adicionado ao texto, explicando os termos (supostamente) estranhos ao público. Toda a narrativa é permeada de um tom humorístico dado, por vezes, pela linguagem regionalista, quase um dialeto, que quebra a seriedade dos eventos sinistros que se desenvolvem. Também porque "a deformação 
cômico-grotesca, o tratamento carnavalesco, o cinismo e a ironia dos duendes irrisórios dissolvem o horror e o elemento aterrorizante de suas revelações." ${ }^{465}$ Assim, versos como "No cupim o macuco piou”, "Nos infernos caí de boléu”, "Vir ao demo servir de pitança", "Amontada numa égua amarela" minimizam o efeito do quadro tenebroso.

Foi Antonio Candido, na Formação da Literatura Brasileira, quem primeiro se deteve no poema, até mesmo reproduzindo algumas de suas estrofes. Para o crítico, a Orgia, "encarada em geral como troça", pode ser considerada "um dos fulcros do nosso satanismo" "466. A aproximação que faz dele com a obra de Hieronymus Bosch reverberou em todos os textos posteriores a ele dedicados - uma analogia forte, que unia o imaginário grotesco do século XV ao romantismo bernardiano sem receio de anacronismo. Apesar de afirmar que o poema "é desses tenebrosos estouros na criação literária, abrindo fissuras por onde jorram os lençóis subjacentes do espírito" ${ }^{467}$, Candido se limitou a elencar a ordem dos acontecimentos do poema, destacando sua “força poética feita de macabro, grotesco e o sadismo certamente mais cruel da nossa poesia.",468

Mesmo sem mais desenvolver as idéias sugeridas - ele o fará mais adiante - a chama acesa por Candido seria catalisadora de abordagens que iriam em direção radicalmente oposta àquela de Jose Veríssimo, que considerava a Orgia da lavra de poesias alegres de Bernardo, cujo "espírito é do melhor gosto, a intenção das mais inocentes e a forma das mais sãs" ${ }^{469}$ Pelo contrário, o que todos se esmeiravam em fazer a partir de então era destrinchar o poema, em busca de suas reentrâncias obscuras, suas mensagens cifradas.

Sussekind já indicava o caminho que seguiria pelo título de seu ensaio, em que nomeia o romantismo de Bernardo de "pé-de-cabra", cujo aroma de enxofre os mais atentos sentiriam de longe na Orgia. O poema, "teatral", com sua série de participantes e suas falas em "estrofes agoureiras" representava o ponto culminante das mudanças na lira bernardiana, primeiro triste e melancólica como se esperaria do jovem ultraromântico, até o "rabecão" e a "bandurra", tocadas na festa dos duendes. As notas

\footnotetext{
${ }^{465}$ MACHADO, 2007, p. 185.

${ }^{466}$ CANDIDO, 1975, p. 175.

${ }^{467}$ CANDIDO, 1975, p. 175.

${ }^{468}$ CANDIDO, 1975, p. 176.

${ }^{469}$ VERÍSSIMO, 1977, p. 146.
} 
explicativas que acompanham o poema serviriam de "contraponto irônico ao tupiguarani e ao 'Canto do piaga' de Gonçalves Dias.” A aproximação entre esses dois poemas havia sido denunciada por Basílio Magalhaes em 1926, ${ }^{470}$ e depois por Haroldo de Campos - mas na questão rítmica, que Luiz Costa Lima reforça: “como não sentir a batida gonçalvina nas estrofes da 'Orgia dos duendes'?"471

Seu ritmo, a propósito, merece comentário à parte. Sabe-se que foi um poema musicado pelo próprio Bernardo Guimarães, que era exímio musicista ( "foi violonista e flautista de rara habilidade, grande conhecedor de música teórica e inspirado compositor de valsas e canções sentimentais" ${ }^{472}$ ) e que o entoava num ritmozinho monótono ao som de viola, ${ }^{473}$ cuja partitura foi disponibilizada em sua biografia escrita pelo neto, Armelim Guimarães. ${ }^{474}$ Carlos José Santos conta que o poeta o cantava "em timbre de tenor", nos encontros com os amigos. Candido comenta que os versos da Orgia tiveram grande difusão por Minas Gerais, principalmente pelo ritmo anapéstico de extrema regularidade, fácil de reproduzir ${ }^{475}$ - tanto que Laura de Mello e Souza lembrava-se de sua melodia, ouvida muitas vezes na infância. ${ }^{476}$ Armelim indica, sem citar, uma impensável versão infantil, incluída em um livrinho de cantigas de crianças ${ }^{477}$ - tamanha sua popularidade, confundida, no passar das décadas, com a tradição oral (o que também aconteceu com o Elixir do pajé).

Um dos motivos para tal certamente era, junto à modulação dos versos, que facilitava a memorização, a combinação de palavras que não apenas eram reconhecíveis à linguagem vulgar como produziam um efeito cômico, ideal para serem cantaroladas em momentos informais - a começar por "Meia-noite soou na floresta / No relógio de sino de pau", passando pelo diabinho que "Pendurado num pau pelo rabo / No borralho torrava pipocas", chegando ao ápice em que "Mais veloz, mais veloz, mais ainda / Ferve a dança como um corrupio"(e sem contar com os nomes caros ao poema,

\footnotetext{
${ }^{470}$ MAGALHÃES, 1926.

${ }^{471}$ LIMA, 1991, p. 245-6.

${ }^{472}$ GUIMARÃES, 1985, p. 148.

${ }^{473}$ CANDIDO, 2004, p. 208.

${ }^{474}$ GUIMARÃES, 1985, p. 148.

${ }^{475}$ CANDIDO, 2004, p. 208.

476476 “É sabido que 'Orgia dos duendes' circulou em regiões de Minas Gerais na forma de cantiga, os versos iniciais sendo entoados arrastada e monotonamente até pelo menos o começo deste século [XX]. Eu mesma conheci essa versão, que minha vó patrena aprendeu em Barbacena com os mais velhos, e cantava para os netos pequenos que ouviam, se lembro bem, sem medo nenhum."(SOUZA, 1993, p. 181) ${ }^{477}$ GUIMARÃES, 1985, p. 150.
} 
como Taturana, Crocodilo, Lobisome, Mula-sem-cabeça, etc, vocábulos de rápida assimilação porque corriqueiros).

Esse uso de uma linguagem regional e onomatopéica, que prioriza o apelo sonoro em detrimento da lógica da ação (produzindo versos que muitos dos críticos consideraram como de nonsense, bestialógico) fez com que Haroldo de Campos, Flora Sussekind e Luiz Costa Lima comparassem a Orgia a um trecho do Segundo Canto do poema $O$ Guesa, do maranhense Sousândrade, que ficou conhecido como Tatuturema. Nenhum deles chega a desenvolver esse confronto, que parece baseado apenas na sugestão de que ambos teriam a influência comum do Walpurgis do Fausto.

Este epísódio do Guesa, publicado dois anos depois do poema bernardiano, em 1867, descreve um suposto ritual indígena, de uma tribo amazônica não especificada, que vive às margens do rio Solimões. Diz Carlos Torres-Marchal, pesquisador da obra de Sousândrade, que o Canto II "mistura crônica de viagem e reflexões sobre a situação dos índos, provavelmente contendo uma base de verdade, mas incrementado pela imaginação do poeta." 478 Para compô-lo, Sousândrade teria se valido de muita informação retirada de livros, inclusive dos termos indígenas, mais do que da experiência, confundindo elementos de tribos diversas. Os versos acabam por ter uma estrutura cacofônica, quase epigramática; os termos usados, muito regionais, são, por vezes, incompreensíveis para os não-iniciados. No festim relatado no Tatuturema, há cerimônia, bacanal, desvario; mas há também um fundo de julgamento sobre a degenerescência dos costumes indígenas, corrompidos em seu contato com os colonizadores - é o que conclui Duda Machado, ao também apontar a semelhança entre ele e o poema dos duendes.

Duda Machado, na edição que organizou com as três peças mais polêmicas de Bernardo, teceu alguns comentários sobre a Orgia. Deles, destacam-se o diálogo que o autor apontou existir entre o poema e o realismo grotesco de Rabelais, teorizado por Bakhtin, ao qual voltaremos mais adiante, e suas considerações a respeito do fechamento do poema. Diferentemente de outros autores, como Sussekind e Costa Lima, que percebem na estrofe final uma tentativa do poeta em amenizar o impacto de sua trangressão, apagando todos os vestígios da demoníaca bacanal da noite anterior, expulsando os criminosos para colocar em seu lugar uma insuspeita virgem apaixonada,

\footnotetext{
478 TORRES-MARCHAL, 2009, p. 3.
} 
Machado vê nessa resolução a manutenção da ironia bernardiana. Ao apelar aos clichês da bela jovem inocente e da natureza apaziguadora, "não há nada semelhante a uma retração, já que o lugar só parece ser ameno ou idílico porque se ignora sua dimensão." Seu caráter ambivalente se reforça nos versos "Nem ao menos se viam vestígios / Da nefanda, asquerosa folia" e, na estrofe seguinte, "E na sombra daquele arvoredo / Que inda há pouco viu tantos horrores", pois indicam que os vestígios e os horrores, aconteceram, estão lá, presentes ao lado da virgem, que desconhece a dimensão noturna e sombria da natureza.

Essa questão do "algo que está lá e que não se vê diretamente" tornou-se central nas análises sobre a Orgia. No ensaio Poesia pantagruélica, Candido retoma a ponta deixada anteriormente (na Formação...) e busca demonstrar uma "segunda camada" de significados nos versos bestialógicos de Bernardo, uma mais profunda e complexa, para além do mero divertimento, aquela que indica a existência de um "desrecalque de violência", manifesta nas figuras sempre presentes de devoração, sangue - "que parecem exprimir um substrato de crueldade, apesar do tom burlesco que as envolve como grande álibi." Para provar essa existência, tenta identificar a mesma camada em outras peças, não de bestialógico, ainda que de humor, e esmiuça, para esse fim, a Orgia.

De acordo com Candido, o poema produz um efeito "extraordinário e raro, parecendo versão brasileira de cenas descritas sobretudo pelos alemães" provavelmente por sua já apontada semelhança com o Walpurgis do Fausto (Armelim Guimarães, nesse mesmo sentido, o chama de "canção hoffmanesca"480). Nota a presença do bestialógico em alguns dos versos da Orgia; porém, deslocado de sua função cômica habitual, configurando-se como um ferramenta de liberação de aspectos inconscientes recalcados: sadismo, crueldade sanguinária, profanação - disfarçados pelo tom de brincadeira, mas atuantes devido a essa ambiguidade produzida. Por ter esses dois sentidos magistralmente trabalhados, um encobrindo o outro, que nunca se revela de todo, é "um dos mais notáveis poemas grotescos da nossa literatura”. Sua comicidade não tem o tom leve de pequenos chistes, transita entre o monstruoso e o sádico, e sua escrita, que valoriza o efeito sonoro, "o baque das palavras secas reforçando o insólito dos intrumentos infernais", assim como o ritmo invariável e

\footnotetext{
${ }^{479}$ CANDIDO, 2004, p. 209.

${ }^{480}$ GUIMARÃES, 1985, p. 149.
} 
obsessivo, desliza rumo ao nonsense e desanda nos automatismos, "que liberam o desrecalque do inconsciente. "481

Em 1993, mesmo ano do ensaio de Candido, a historiadora Laura de Mello e Souza publicou Inferno Atlântico, sua pesquisa sobre a demonologia no Brasil colonial. O epílogo da obra é um curto comentário a respeito da Orgia que, para a autora, é um texto emblemático do amálgama de certas tradições européias com outras brasileiras, que se entreteciam vagarosamente nos séculos anteriores. Pertencente à linha da histórias das mentalidades, o método de Laura atesta como elementos do imaginário europeu do sabá das bruxas (o zoomorfismo, a dança ritual, as práticas de magia utilizando pedaços humanos) vieram de Portugal e se misturaram, na longa duração, à algumas referências especificamente brasileiras (seres transfigurados do folclore, danças de origens indígenas e africanas, linguagem e fauna local) - se acomodando à cultura popular dos trópicos e culminando, no século XIX em uma poema como a Orgia, em que já não se distingue mais o que é tipicamente daqui ou de lá.

Daí a alegação eufórica de Basílio de Magalhães, biógrafo de Bernardo, de que esse é o poema "mais brasileiro" da lavra bernardina, poder ser decididamente contestada. Laura tenta mostrar como, apesar dos traços regionais, o poema se insere em uma linhagem de literatura sabática de matriz européia, que começa no século XV e segue até a apropriação do fenômeno pelos românticos, como Victor Hugo, Théophile Gautier e, obviamente, Goethe. Mesmo com essa ascendência, o poema "harmoniza, de forma impressionante" as duas tradições. E mais: construindo uma ponte com o texto de Antonio Candido, a historiadora conclui que, como toda literatura ocidental do período, a Orgia discorreria, de forma codificada, sobre os fantasmas da sexualidade - o demônio internalizado inventado pelos oitocentos em substituição ao demônio externalizado no outro. $^{482}$

Na pista aberta por Candido e estimulado pela leitura de Laura de Mello e Souza, Vagner Camilo explorou a densidade psicológica da Orgia, principalmente esse "fundo perverso em que se assenta o poema" que passa despercebido pelo leitor

\footnotetext{
${ }^{481}$ CANDIDO, 2004, p. 210-11.

${ }^{482}$ Que era a própria personificação do diabo ou daquele que o servia e que foi alvo de perseguição nos séculos modernos. Laura faz uma interessante analogia entre esse outro demoníaco, e as terras tropicais, impregnadas de crenças, folclores e mitos - o outro demoníaco de uma Europa primeiro cristã e depois racionalista, no século XVIII.
} 
médio. ${ }^{483} \mathrm{O}$ crítico dedica um capítulo inteiro de seu Riso entre pares só à Orgia, numa atitude sem precedentes até então, levantando sua fortuna crítica e retomando, ao mesmo tempo em que aprofunda, vários dos insights de seus antecessores (a retirada do humor bernardiano do cânone, a comparação com o Tatuturema e o Canto do Piaga, a construção métrica e a sonoridade dos versos, sua filiação com o gênero da balada, o caráter grotesco dos personagens e a presença do elemento popular, seja nas referências à linguagem e à fauna local ou ao fundo de histórias e crenças folclóricas). Camilo, assim como Mello e Souza, insere o poema na tradição sabática de Goethe (notadamente, do Fausto, matriz de todas as demais), de Victor-Hugo, de T. Gautier e de Espronceda, que afirma serem autores bem conhecidos de nossos românticos.

Mas Camilo também oferece sua contribuição interpretativa, em que o motivo da noite é um de seus guias: “o domínio do mistério, do sobrenatural, da anormalidade e do inconsciente liberto em sonho ou, no limite extremo, em pesadelo. ${ }^{484}$ Por ser o avesso do dia - momento da razão, do trabalho, da luz - é o período da vulnerabilidade, em que o mundo se abre a toda sorte de horrores: o mal, a morte, o erro, o pecado, o irracional, o sobrenatural. Ela é a temporalidade ideal para que ocorra o retorno do reprimido - não por acaso, é na noite da floresta que a orgia dos duendes acontece. As representações fantasmáticas presentes no poema (espíritos, seres monstruosos como o lobisomem e a mula-sem-cabeça), assim como os crimes cometidos ou sofridos por elas em vida (que incluem práticas sexuais incestuosas, esquartejamento e antropofagia) seriam imagens simbólicas da castração: "teríamos assim configurado no poema uma espécie de reativação de um certo temor infantil (o da castração)." A esse movimento de liberação da sexualidade recalcada que Camilo observa na Orgia, ele ainda inclui um outro, que deduz de sua leitura de Laura de Mello e Souza: um desbloqueio violento dos "fantasmas da alteridade" de nossa cultura, recalcados pelos padrões civilizatórios da velha Europa.

Não eram, no entanto, apenas os padrões civilizatórios europeus o objeto da chacota bernardina, como demonstra Cilaine Alves Cunha em Representações da arte popular: natureza e artifício no Romantismo brasileiro, artigo publicado em 2012. Aquela era uma época, meados do século XIX, na qual a maneira como se tratava a identidade do povo e a cultura popular revelava um posicionamento político:

${ }^{483}$ CAMILO, 1997, p. 172.
${ }^{484}$ CAMILO, 1997, p. 159. 
o modo de cada romântico representar a cultura popular depende da defesa ou veemente rejeição do mito do progresso e do nacionalismo estatal patrocinado por D.Pedro II. Liga-se por similaridade ou contraposição, aos esforços da corte para construir o sentimento de pertencimento à nação (...) a estilização da cultura popular entre os romântico depende, enfim, de uma maior ou menor adesão ao iluminismo e ao cristianismo, implicando rejeição ou promoção do sincretismo cultural e religioso. ${ }^{485}$

Apesar de ter aderido ao modelo indianista e nacionalista em seus romances da maturidade, Bernardo teria deixado entrever em algumas poesias uma outra postura, contrária ao indianismo idealizado que fora promovido a mito fundador da sociedade brasileira e servia de base para um projeto político potencializador do sentimento nacionalista. A Orgia dos duendes seria, justamente, o exemplo mais eloquente.

Para comprová-lo, Cilaine problematiza o Glossário, apresentado ao fim do poema, demonstrando que ele mais ironiza do que explica. Seu primeiro e mais evidente alvo seria esse mesmo recurso colocado por Gonçalves Dias ao fim do Canto do piaga, no qual elucida uma série de termos indígenas utilizados em seus versos, considerados raros, distantes do repertório dos leitores. Além do Glossário de Bernardo incluir palavras de origens diversas à indígena (como que sugerindo que toda a cultura brasileira também provém de fontes diversas), trataria de vocábulos conhecidos e recorrentes à época, como mutuca. Para outras palavras, inventa ou fixa um único significado, "dessa forma, aponta, com muito bom humor, para a prática indianista de forjar um sentido único para termos indígenas a fim de que eles se adaptem ao arbítrio poético nacionalista. "486

Concluindo sua análise, Cilaine traria ainda outro considerável aporte à leitura do poema, ao revelar o fundo político da última estrofe, no qual o cenário idílico e a passagem da jovem virgem encobrem as cenas anteriores de horror e os relatos criminosos daqueles personagens que fizeram parte de uma elite eclesiástica e aristocrática. Ao apelar para os clichês românticos para esconder os horrores transcorridos, Bernardo denunciaria o uso dessa literatura abundante em sentimentalismos e incentivada pelo Imperador para, hipocritamente, mascarar "de um

\footnotetext{
${ }^{485}$ CUNHA, 2012, s/p.

${ }^{486}$ CUNHA, 2012, s/p.
} 
lado, a corrupção subterrânea dos costumes praticada por membros do 'antigo regime' e, de outro, os traços múltiplos da cultura brasileira. "487

O artigo de Cilaine parece ser a última contribuição realmente relevante para a fortuna crítica da Orgia dos duendes - e, interessante, o único que não se baseia em sua relação com o imaginário sabático e/ou satanista.

\section{A linhagem macabra da Orgia dos duendes}

Tendo em vista a herança crítica relativamente pequena e apta a ser melhor explorada de A orgia dos duendes, parece apropriado oferecer outras perspectivas. Não se trata de desmerecer os critérios anteriores de análise, bastante pertinentes, por sinal, mas de contribuir com uma nova possibilidade: a de que o poema pertença também à linhagem do macabro - mais especificamente, que seja um exemplar de dança macabra.

Não soa impossível a hipótese de Bernardo Guimarães ter conhecimento do imaginário das danças: é bastante significativo que o tenha sugerido novamente no conto A dança dos ossos, publicado em Lendas e romances, apenas seis anos depois de Poesias. Como já visto, na história, um caboclo testemunha a aparição de um animado esqueleto recém-saído da terra, com o objetivo único de balançar seus ossos e sacolejar suas articulações em uma alegre coreografia - e depois assustá-lo, quase matando-o de terror. O título da narrativa praticamente entrega a fonte de inspiração do autor, independente de ter conhecido empiricamente o gênero.

O amigo Álvares de Azevedo teria se apropriado do repertório macabro, conscientemente ou não, em cena de seu Conde Lopo. Ou seja, a narrativa dos cadáveres que confraternizam, bebem e depois voltam às profundezas obscuras da morte era um tema que circulava entre os jovens poetas - vimos com Paulo Franchetti e Vagner Camilo como o contato com os pares influenciava e disseminava certas imagens poéticas. E seus escritores europeus preferidos (Goethe, Gautier, Hugo, Espronceda...)

\footnotetext{
${ }^{487}$ CUNHA, 2012, s/p.
} 
não apenas sabiam da existência das danças como as teriam visto in loco ou impressas e, mais importante, escreveram as suas versões do tema. Como eram ávidamente consumidos no Brasil, é provável que alguma dessas obras tenham chegado aos nossos românticos.

É curioso notar como a menção às danças macabras, de certa maneira, aparece nos críticos que se detiveram na Orgia, mas empregam-na de maneira banal, para descrever os eventos, sem contudo deixar clara sua intenção com o uso do termo. Fica a sensação de que uma dança macabra seria um sinônimo à "festa extravagante de grande descontrole", ou algo assim. Note-se: Vagner Camilo fala que, na terceira parte do poema, tem início uma "verdadeira danse macabre, com os duendes bailando alucinadamente ao redor da fogueira". ${ }^{488}$ Mais à frente, afirma que o poema chega a “atingir a dimensão do macabro" 489 em algumas estrofes, e ainda, que se trata de um "universo macabro" 490 , sem indicar com mais clareza o que isso significa. O mesmo acontece com Duda Machado, que atenta para o fato de que "o macabro faz parte da diversão e se incorpora ao carnaval dos duendes "491 e chama o baile de "dança hiláriomacabra" e de "folia macabra." 492 O sentido de "macabro", assim como o de "dança macabra", se perde, quando poderia ser, na verdade, uma chave de leitura para a peça, tão relevante quanto o sabá, o satanismo, o bestialógico ou o regionalismo bernardiano.

Dito isso, cabe expor a seguir os aspectos de filiação d'A orgia dos duendes à tradição macabra, que teve início no século XIV europeu e se estendeu ao século XIX, nos romances góticos e na poesia daqueles mesmos autores também obcecados pelo sabá e pelo satanismo. Lidos no Brasil, poderiam ter influenciado uma produção que adotaria suas características, de forma declarada ou não, e das quais o poema de Bernardo Guimarães seria a grande representante por sua aproximação com a forma mais produzida da tópica macabra: a dança dos mortos.

Esse acercamento se dá desde seus fatores mais evidentes: o início da narrativa à meia-noite (a hora, por excelência, do regresso dos mortos), a saída das covas e dos

\footnotetext{
${ }^{488}$ CAMILO, 1997, p. 168.

${ }^{489}$ CAMILO, 1997, p. 169.

${ }^{490}$ CAMILO, 1997, p. 170.

${ }^{491}$ MACHADO, 2007, p. 183.

${ }^{492}$ MACHADO, 2007, p. 185 e 186.
} 
recônditos obscuros que escondem a morte e a abjeção - elementos que remetem aos operadores das obras produzidas nos oitocentos. ${ }^{493}$

A crítica social presente nos relatos dos protagonistas do poema foi um traço igualmente importante das danças macabras medievais. Quando falam de seus crimes, todos na Orgia explicitam seu pertencimento à elite, seja em altas posições hierárquicas no clero ou na nobreza. A denúncia era, especialmente, de uma Igreja entregue à práticas sacrílegas mais infames. "Frei" Galo-preto gozava das delícias da carne - da gula desenfreada e da luxúria. Um celerado homicida, responsável por incontáveis execuções: eis o monge Esqueleto. Crocodilo foi um Papa libertino que botava veneno nas hóstias. Ao seu modo, as mulheres do grupo também participaram dos ultrajes eclesiásticos. Taturana foi freira, apesar da relação incestuosa com o pai; Getirana, por seu envolvimento amoroso com um abade e com um frade, tornou-se uma atroz assassina; Mula-sem-cabeça foi amante de um bispo que a introduziu no repertório dos transgressões.

Nas danças medievais, os religiosos era frequentemente alvo da ironia da Morte ou do morto que vinha buscá-los. Não adiantava ludibriá-lo ou fingir inocência, na hora de sua chegada, o cadáver já declarava saber de todos os delitos cometidos.

Na edição de 1486 na Danse Macabre de Guyot Marchand, o abade é um dos alvos dessa onisciência. Um morto o surpreende, ordena que não fuja e nem se surpreenda! É tempo que abandonar a abadia onde comeu do bom e do melhor. E com notável sarcasmo, avisa: os cadáveres mais gordos, apodrecem primeiro.

Le mort

Abbé, venez donc! Vous fuyez! N'ayez pas la mine ébahie.

Convient il que vous fuyez la mort?

Combien l'avez vous haïe!

Dites donc adieu à l'abbaye

Qui gros et gras vous a nourri.

Vous pourrirez vite: chez la mort

Le plus gras est premier pourri. ${ }^{494}$

\footnotetext{
${ }^{493}$ Ver Capítulo 3.

${ }^{494}$ UTZINGER, 1996, p. 281.
} 
A dança macabra de Berna (1514-1522) é especialmente dura com os membros da Igreja, pois acusa o bispo, o abade e os monges de perverter as regras. A gula parece ser um pecado ostensivamente praticado, como demonstra o diálogo da Morte com o abade:

La mort dit à l'Abbé:

Monsieur l'Abbé, vous êtes bien gros et gras, Sautez avec moi dans cette ronde! Comme vous voilà couvert de sueurs froides! Fi! Fi! Vous lâchez de gros excréments!

Réponse de l'Abbé:

Les petites bouchées m'ont fait tant de bien, J'avais en main de grandes richésses, Elles ont servi la volupté de mon corps, Maintenant mon corps est la proie des vers. ${ }^{495}$

Os monges são tratados com severidade, descritos como "lobos em pele de cordeiro", cheios de todo tipo de pecado (o Esqueleto da Orgia poderia estar entre esses monges medievos):

La mort dit aux Moines:

Vous Moines, vous vous engraissez bien,

Vous êtes pleins de tous les péchés,

Vous êtes des loups en peau de mounton,

Il vous faut danser, même si vous en avez de la peine. ${ }^{496}$

Na Danza General, poema castelhano de meados do século XV, a ironia recai sobre o arcebispo e o bispo. O primeiro, ao ser chamado, se apavora, pois viveu a vida em deleites e não regeu corretamente sua paróquia. Ao invés do Céu, sabe que vai para o destino oposto:

¡Ay muerte cruel! ¿Qué te merecí, o por qué me llevas tan arrebatado?

${ }^{495}$ UTZINGER, 1996, p. 294.

${ }^{496}$ UTZINGER, 1996, p. 295. 
viviendo en deleites, nunca te temí;

fiando en la vida, quedé engañado.

mas si yo bien rigera mi arzobispado,

de ti non hubiera tan fuerte temor.

mas siempre del mundo fui amador,

bien sé que el infierno tengo preparado. ${ }^{497}$

A Morte concorda: "pues tan mal registes / vuestros subditos y clerecía", comendo "manjares diversos con gran golosía,/ estar non podredes en Santa María”,498 O abade, por sua vez, é chamado de "folgado, vicioso", que em vida, só desejou "placeres y vicio" - ele, que "era abastado de plata y oro,/de nobles palacios y mucha folgura”. O mesmo personagem aparece na Dotendantz (ca. 1490) ${ }^{499}$, com um tratamento parecido. A Morte lhe diz que deveria ter melhor gasto os bens do monastério - alimentando os pobres. Esse, responde: “Je n'ai jamais vraiment respecté le réglement de mon ordre."

Um outro elemento que liga a Orgia à estética macabra é a presença de trechos que expõem despudoradamente o resto mortal, seja como alimento: o corpo de um garoto levado à panela "com tripas e tudo"; uma sopa temperada com "o sangue de um velho morcego", sangrado ali, na hora; o "fresco lombro de um frei dom abade" colocado na frigideira com as banhas de um frade, seja como aparelhos musicais: uma caveira, "com badalo de casco de burro" fazendo as vezes de uma campainha; uma rabeca (instrumento preferido da Morte), ou melhor, um “feroz rabecão”, construído com a carcaça de um defunto seco e com as tripas de um velho barão. A orquestra era regida por Lobisome, que segurava uma batuta feita “co'a canela de um frade que tinha / Inda um pouco de carne corrupta" - um gracioso preciosismo macabro.

Fora os equipamentos feitos de despojos humanos e animais, havia uma grande diversidade de instrumentos musicais (matracas, batuques, a barriga inchada de um sapo tocada como percussão, berimbau, bandurra). Essa quantidade enfatiza a presença de uma música contagiante e frequente em toda a ação do poema, o que se relaciona com a questão musical das danças macabras, crucial para manter o ritmo que anima os mortos - anima, dando-lhes vida temporariamente. Por isso a importância dos cadáveres-

\footnotetext{
${ }^{497}$ OQUENDO, 1983, p. 29

498 "Santa Maria = empleado geralmente por Catedral, ya que estas solían estar bajo tal advocación" (HURTADO y CVITANOVIC, 1966, p. 15)

499 citada em sua tradução francesa Danse macabre. (fac-similés et traduction de Der doten dantz mit figuren, 1490). Maxéville: Presses Universitaires de France, Foundation Martin Bodmer, 2011, Collection Sources.
} 
músicos, como os da Orgia. Perceba-se: o verso "Esqueleto tocava tambor", a rigor, poderia estar em uma dança macabra. (figura 1)

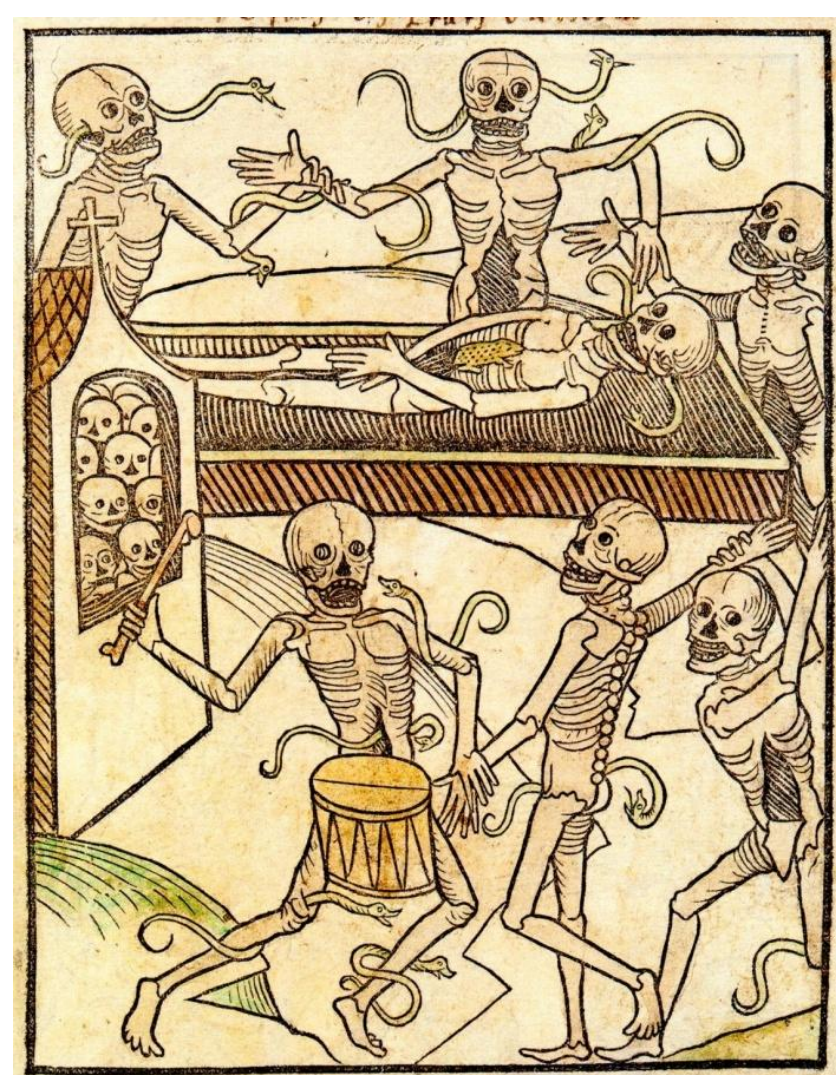

Figura 1. Gravura no frontispício da Dotendantz, ca. 1490.

Os personagens da Orgia se encontram tão somente para confraternizar, dançar e contar suas histórias - o que caracteriza, justamente, um dos operadores das danças macabras produzidas no século XIX ${ }^{500} \mathrm{O}$ motivo se repete em A dança dos ossos, conto de Bernardo de 1871. A despeito de apavorar a população local, o esqueleto de Joaquim Paulista nunca causou mal físico algum a ninguém. Ele apenas pula, baila, sacoleja e bate as articulações, assustando aqueles que testemunham seu retorno à superfície:

(...) os ossinho mais miúdos, dançando, dançando sempre e batendo uns nos outros, foram-se juntando e formando dois pés de defunto. Estes pés não ficam quietos, não; e começam a sapatear com os outros ossos numa roda viva. (...) Os ossos dos quadris, as costelas, os braços, todos esses ossos que ainda agora saltavam espalhados no caminho, a dançar, a dançar, foram pouco a pouco se ajuntando e embutindo uns nos outros, até que o esqueleto se apresentou inteiro (...)

\footnotetext{
${ }^{500}$ ver Capítulo 3.
} 
Também, obviamente, a coreografia frenética que toma lugar no início da terceira parte do poema remete diretamente ao rendez-vous macabro. Convulso, extático, o baile em volta da fogueira é comparado a um "fatal rodopio" que segue em direção ao seu ápice, "mais veloz, mais veloz, mais ainda”. Essa imagem de frenesi seria cabível em grande parte das danças macabras, mas destaco uma, provavelmente conhecida de nosso autor, a do casamento de Dom Félix Montemar, de El estudiante de Salamanca, de Espronceda (1840).

Y algazara y gritería, crujir de afilados huesos, rechinamiento de dientes . y retemblar los cimientos, y en pavoroso estallido las losas del pavimento separando sus junturas irse poco a poco abriendo, . siente Montemar, y el ruido más cerca crece, y a un tiempo escucha chocarse cráneos, ya descarnados y secos, temblar en torno la tierra. (...)

Mientras, la ronda frenética que en raudo giro se agita, más cada vez precipita su vértigo sin ceder; . más cada vez se atropella, más cada vez se arrebata, y en círculos se desata violentos más cada vez. ${ }^{501}$

Em meio à desvairada dança, Dom Félix sente vertigens e começa a perder os sentidos - o mesmo ocorre com o Conde Lopo (1848), de Álvares de Azevedo. Coagido a participar da ciranda delirante, o Conde não suporta os rodopios e desmaia:

O circulo infernal com força infinda

Corria como em vórtices a tromba

Sobre as águas do mar sorvendo vagas

- Bebedouro de nuvens. -

${ }^{501}$ ESPRONCEDA, 2014, p. 66-72. 
A vertigem

Do Conde se apossou - Também volvia

No geral turbilhão

\section{As coloridas}

Vidraças multicôres reluziam

Com luz escassa, como sóe em horas

Em que a aurora vai sahir nos montes. ${ }^{502}$

Além do poeta espanhol, outros autores reverenciados por nossos românticos escreveram suas danças macabras, como Goethe, Théophile Gautier, Victor-Hugo, Nerval, Baudelaire. Não é necessário retomar essas peças, já comentadas em capítulo anterior. Mas, independente do contato que Bernardo Guimarães possa ter tido ou não com elas, é interessante relembrar o quanto o imaginário romântico estava impregnado desta referência.

Esses seriam os aspectos macabros mais óbvios, mas há outros.

Em primeiro lugar, o fator mais importante, e que parece ter escapado a todos os críticos, é a evidência de que os protagonistas da Orgia - Rainha, Taturana, Getirana, Galo-Preto, Esqueleto, Mula-sem-cabeça, Crocodilo e Lobisome -, os personagens que são nomeados e que contam as suas histórias, estão mortos. Antes de serem duendes, bruxas ou seres místicos, eles são cadáveres. O único que parece ter notado essa particularidade foi Duda Machado que, no prefácio à edição de Poesia erótica e satírica (obra utilizada para as citações dos versos), comenta:

Uma fauna medonha, formada por mortos travestidos de bichos-personagens de lendas populares e por insetos típicos, compõe os duendes em orgia. Lobisome, Getirana, Mamangava deixam suas covas depois de meia noite, reencarnam e passam a se dedicar a uma série de monstruosidades. ${ }^{503}$

Mesmo com esse apontamento, o autor continua tratando-os como duendes, nunca como cadáveres. ${ }^{504}$ Os grifos na citação acima são todos nossos. Explica-se: de fato, o poema deixa claro que os atores principais da orgia estão mortos - todos contam

\footnotetext{
${ }^{502}$ AZEVEDO, 1886, p. 121.

${ }^{503}$ Machado in: GUIMARÃES, 1992, p. 12.

${ }^{504}$ Três anos depois, em um ensaio de Machado para a Revista USP, já não aparece essa mesma consideração - nesse texto, os personagens são pura e simplesmente "duendes". (MACHADO, 2007, p. 174-187)
} 
as peripécias de quando viviam e as circunstâncias de suas mortes. Não assume porém, em nenhum momento, que estariam travestidos, tampouco que reencarnam em outros seres. A indefinição de sua natureza causa a diversidade de interpretações. No entanto, há de se observar que um deles, Esqueleto, fala por si só sobre sua compleição, confirmando seu feitio macabro.

Os outros cadáveres, dentro do contexto da inversão carnavalesca que a orgia representa teriam a constituição do corpo-processo da carnavalização ${ }^{505}$, impregnado de vida enquanto se decompõe, misturado à natureza, se confundindo com ela. São da ordem do grotesco porque são híbridos em sua caracterização: Bernardo concede a esses personagens os nomes de animais repulsivos e perigosos, como a taturana (lagarta peluda que que não pode ser tocada), o crocodilo, o galo-preto. Esse tipo de animal é preferido da estética grotesca, afirma Wolfgang Kayser: “O grotesco gosta de todas as sevandijas. " ${ }^{506}$ Esse favoritismo se dá, principalmente, por serem seres que vivem nos locais "inacessiveis ao homem", ou de "proveniência pouco clara" exatamente o caso dos cadáveres macabros que emergem dos subterrâneos obscuros, por métodos enigmáticos aos vivos.

Mas os nomes provém também de seres fabulosos do anedotário local, ${ }^{508}$ como o Lobisome e a Mula-sem-cabeça; ou, ainda, seres inventados (monstruosos, portanto), como a Getirana, cuja definição no Glossário, resulta em um bicho disforme e completamente inimaginável, como demonstrou Cilaine Alves Cunha:

Pouco a pouco, no entanto, compõe o elemento da fauna brasileira como um monstro repulsivo e agressivo: possui asas de cigarra maior que o corpo, sendo este oblongo como o da borboleta, e uma grande cabeça semelhante à da serpente. $\mathrm{O}$ desenho pinta, assim, um todo desarmônico formado de partes da cigarra, cobra e borboleta. ${ }^{509}$

\footnotetext{
${ }^{505}$ Ver capítulo 4.

${ }^{506}$ Há animais preferidos pelo grotesco, como serpentes, corujas, sapos, aranhas - os animais noturnos e os rastejantes, que vivem em ordens diferentes, inacessíveis ao homem. (KAYSER, 1986, p. 157)

${ }^{507}$ KAYSER, 1986, p. 157.

${ }^{508}$ A utilização da referência local, tanto no nome dos protagonistas quanto no vocabulário, especialmente no trato dos personagens e na maneira como conversam entre eles, é um dos aspectos de comicidade do poema, segundo Duda Macahado: A familiarização carnavalizadora com que os duendes são tratados nessas passagens vai destituí-los de sua condição de forças estranhas e terroríficas para dar-lhes um tom familiar e risível, uma espécia de apródia de seres infernais. (MACHADO, 2007, p. 183.)

${ }^{509}$ CUNHA, 2012, s/p.
} 
Os mortos que se fundem a essas formas de vida mestiças e degradas quando voltam à terra do poema vinculam-se à imagem dos cadáveres dançarinos transfigurados em tarântulas do Promontorium Somnii (1864), de Victor-Hugo - com suas cabeças grudadas a tocos de pescoço carcomido e rodeadas de vértebras que lembram as patas do aracnídeo. O grotesco do poema de Hugo se repetiria na Orgia ${ }^{510}$ em que esses defuntos, ao retornarem ao mundo para a festa, emulam os animais asquerosos, não necessariamente assumindo a sua existência (talvez assumindo sua inexistência), mas como seres em mutação - que os cadáveres são, afinal de contas. Ou seja, não transformados nelas (ou reencarnados nelas), mas como elas: vivendo nos locais inacessíveis, tornados alheados ${ }^{511}$ e abjetos ${ }^{512}$ como os parasitas e insetos imundos e os bichos monstruosos que lhes dão nome. Carnavalizados pois sua ocorrência dupla mistura as noções de alto e baixo (as nobres hierarquias sociais quando vivos, a condição animalesca quando mortos). ${ }^{513}$

E se o motivo oitocentista das danças macabras acontecerem era a confraternização entre os mortos, o mesmo se dá no poema. Convidados a contar suas histórias e as condições que os levaram ao óbito, os personagens revelam uma variedade de crimes que não faria inveja a nenhuma novela gótica. Assassinatos de toda espécie, estupro, incesto, aborto, libertinagem... A exploração dos delitos e perversões humanas, porém, ocorre em "chave paródica", como diria Duda Machado, em que a crueldade sadicamente narrada e descrita em seus pormenores se esvazia pela ironia e cinismo das falas dos personagens. ${ }^{514}$ É parecido com o que se passa em La danse des morts, de Gérard de Nerval (1855) em que os mortos são também chamados a relatar suas biografias, que eram sempre recebidas com gritaria, gargalhadas e palmas dos ouvintes que se deleitavam com as tragédias:

\footnotetext{
${ }^{510}$ Sabe-se com que intensidade Victor-Hugo foi lido e admirado no Brasil oitocentista. Leila PerroneMoisés chega a analisar os textos de Castro Alves, um de seus principais leitores, concluindo que o poeta baiano não apenas copiava versos e estilo do francês, mas que conseguiu emular seu processo de produção, criando imagens análogas à de Hugo antes mesmo dele. (PERRONE-MOISÉS, Leyla. Castro Alves e o aplicativo Victor-Hugo. In: Vira e mexe, nacionalismo: paradoxos do nacionalismo literário. São Paulo: Companhia das Letras, 2007.)

${ }^{511}$ Faz parte da natureza do grotesco, como afirma Wolfgang Kayser, o pertecimento a um mundo alheado, isto é, tornardo estranho: "Para pertencer a ele, é preciso que aquilo que nos era conhecido $e$ familiar se revele, de repente, estranho e sinistro." (KAYSER, 1986, p. 159)

${ }_{512}$ Sobre o conceito de abjeto, ver o Capítulo 2.

${ }^{513}$ Por isso, aqui discordamos, uma vez mais, de Duda Machado quando diz que o poema, "ao invés do corpo hibrido'analisado por Bakhtin em Rabelais, temos a 'criatura híbrida'(corpo animal e condição humana)" (MACHADO, 2007, p. 181). Como já se deixou claro, não acreditamos que o poema evidencie esse "corpo animal" e os personagens, em nossa leitura, são cadáveres humanos relegados à uma condição animal.

${ }^{514}$ MACHADO, 2007, p. 185.
} 
"Nous reposons toute l'année, silencieux comme des souris dans nos sépulcres; soyons joyeux aujourd'hui! (...) il faut que chacun de nous raconte fidèlement ce qui l'a autrefois entraîné, et comment l'a harcelé et déchiré cette folle chasse amoureuse." (...)

Et le fou rire redoubla, et la blanche troupe flotta en cercle. ${ }^{515}$

Um outro elemento que estreita a distância entre o poema e a tradição macabra é a presença da morte personalizada. Era comum, nas danças macabras, a noção de um desdobramento da figura da morte, podendo ser representada como a Morte ou replicada em seus emissários, os mortos, que voltam à terra. Temos na Orgia, a participação desses seus mandatários, os protagonistas, mas temos também uma duplicação da Morte personalizada - a Rainha e a Morte cavaleira que encerra a festa.

A aparição da Rainha é emblemática: ela inicia e coordena os trabalhos, sentada em um tablado que lhe serve de trono. Dá ordens, faz o chamamento. Sua imagem me remete diretamente à da Morte antropomorfizada que tantas vezes liderou as danças macabras medievais. A figura esmaecida, de “mãos ressequidas” lembra a de Macabre, o coveiro do conto de Paul Lacroix, ambos personagens de passado misterioso e inclinados a malefícios. Ambos, tocando seus intrumentos para acordar os mortos Macabre, sua rabeca; a Rainha, um batuque. Ambos, criminosos, sósias da própria Morte terrível, que amedronta, que carrega quem cruza seu caminho. A Rainha, como ela mesma conta, foi, quando viva, a pessoa mais terrível que se têm notícia, cometendo toda sorte de atrocidade: matricida, parricida, fratricida, assassina de três maridos e vários amantes - com frieza e maldade. Uma verdadeira fâcheuse, uma figura do excesso.

Ela é também a Morte coquete, orgulhosa de seus crimes, flertando com os convivas - tal como a Morte-cadáver da Danse macabre de Baudelaire (1861). Ao Galo-preto, ela pede, faceira: "Vem agora esquecer tua sorte, / Vem-me em torno arrastar tuas asas". Chamando Crocodilo de "gentil", lhe oferece a bebida que fez com o pranto de viúvas; com Lobisome, ela troca intimidades ("Lobisome, que fazes, meu bem"). Ao Esqueleto, ela insinua carinhos:

${ }^{515}$ NERVAL, 1855, p. 355. 
Onde estás, que inda aqui não te vejo,

Esqueleto gamenho e gentil?

Eu quisera acordar-te c'um beijo

Lá no teu tenebroso covil.

De sua existência pregressa, conta dos diversos "amantes de um dia" que, "no banquete infernal da luxúria”, dava cabo sem piedade, depois de saciados seus desejos. Esses versos do poeta francês sobre a Morte no baile conviriam para a Rainha da Orgia:

Et viens-tu demander au torrent des orgie De rafraîchir l'enfer allumé dans ton coeur? Inépuisable puits de sottise et de fautes! De l'antique douleur éternel alambic!

Se a Rainha é a Morte impiedosa e implacável, estridente, ruidosa, ela divide o espaço do poema com a outra metade do binômio que forma com a Morte cavaleira, que aparece para encerrar a orgia quando essa está em seu auge. Montada em uma égua amarela, ao longe se vê seu "magro espectro" e, a medida em que se aproxima, fazendo barulho ao chacoalhar os ossos no galope, é possível perceber seu "hediondo esqueleto". Tal como num Triunfo da Morte (figura 2), ela determina o fim da balbúrdia, enxotando a "nojenta canalha". Ela atua como a solução final de um evento que não acabaria pela iniciativa dos convivas. Assustadora mesmo para os seres mais ignóbeis, seu poder ilimitado não conhece as fronteiras entre o mundo natural e sobrenatural. Com sua voz rouca, bradava:

"Fora, fora! esqueletos poentos, Lobisomes e bruxas mirradas! Para a cova esses ossos nojentos! Para o inferno essas almas danadas!" 


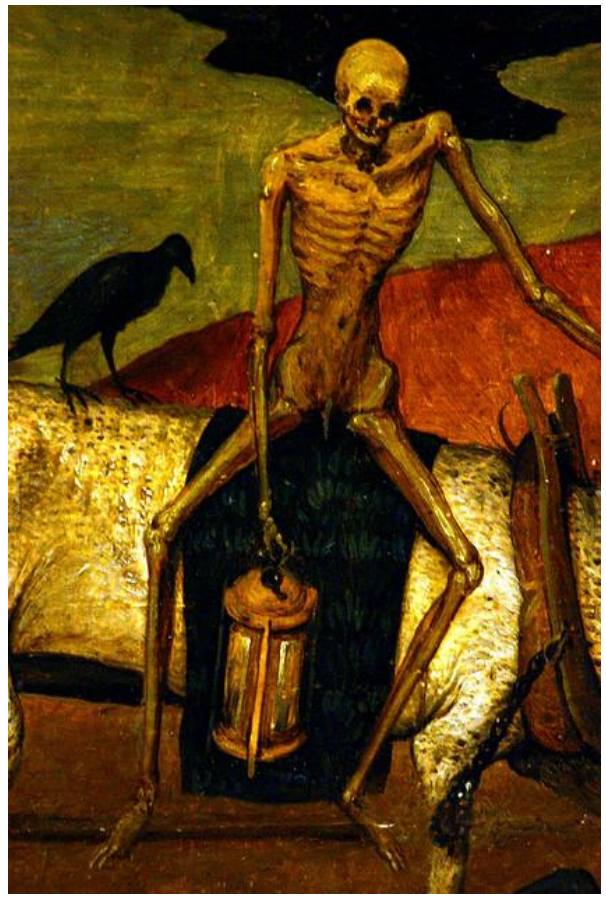

Figura 2. Pieter Bruegel, Triunfo da Morte (detalhe). ca 1562

A dança macabra da Orgia dos duendes não deve nada ao modelo europeu. Ultrapassa-o, adaptando suas características medievais e românticas ao linguajar e ao folclore locais. O poema se configura, assim, como exemplar dos mais especiais do imaginário macabro, revelando seu impacto e sua acomodação à cultura literária do Brasil oitocentista. 


\section{Considerações finais}

O discurso literário e as artes visuais exprimem, em maior ou menor grau, as respostas de uma época a certas demandas. Quando as imagens de corpos em decomposição invadem a poesia e a iconografia medieval no século XIV, a devastação causada pela Peste Negra que expunha a corrupção da morte física ainda latejava nas mentalidades da época. Mas vimos que essa foi apenas a ponta aparente de um fenômeno maior, de valorização da vida material e afastamento de algumas certezas sustentadas pela fé.

Essa noção se apronfudaria ainda mais às vésperas do triunfo burguês revolucionário. No final do século XVIII, a percepção do óbito como extinção da existência se tornava ainda mais contundente e o macabro ressurge em todo seu esplendor, como elemento crucial da preocupação com a finitude. Afinal, aquele corpo que se dissolve era, na percepção vitoriana, tudo o que restava do sujeito e daqueles que ele amava. ${ }^{516}$

Daí o Romantismo abraçar com ímpeto o tema. A ênfase no indivíduo e as angústias com o passamento, característicos do movimento, fazem com que a idéia de cadáveres deteriorados seja uma fonte paradoxal de horror e encantamento.

A dança dos mortos era a grande síntese de tudo o macabro problematizava: a dissolvição do corpo, as dúvidas com a eternidade post-mortem, a universalidade da morte que ignorava classe, idade e gênero. Por isso foi motivo frequente na poesia e na prosa românticas, cujos autores, muitas vezes, conheciam as danças originais da Idade Média.

Mas o século XIX coloriu com suas próprias tintas as cenas macabras, inserindo os mortos dançarinos nas festas dos vivos, emulando as suas maneiras de se divertir. Esses defuntos não voltam mais à superfície para carregar consigo suas vítimas - eles preferem o baile, a música, a bebida, a orgia.

\footnotetext{
516 As manifestações do apego excessivo ao morto inauguradas pela cultura oitocentista, como o luto prolongado, as visitas ao cemitérios, o uso de relíquias como acssório indumentário e a prática das fotografias mortuárias foram anteriomente estudadas em SCHMITT, Juliana. Mortes Vitorianas. Corpos, luto e vestuário. São Paulo: Editorial Alameda, 2010.
} 
Por isso, o díptico formado pela gravura publicado no jornalzinho $O$ Cabrião (1866) e pelo poema A orgia dos duendes (1865), que abrem e fecham este trabalho, parece tão representativo. Cada um, a sua maneira, oferece o olhar oitocentista à morte $\mathrm{e}$ às danças macabras. $\mathrm{O}$ primeiro, apresentando os elementos emblemáticos da sensibilidade ultra-romântica: a noite, como o momento das revelações; a floresta como a natureza sublime e assustadora que esconde segredos; os seres grotescos e monstruosos da imaginação; a atmosfera de profanação satânica; a coletânea de crimes à la narrativa gótica; a ironia da virgem que cisma de amores ignorando os mistérios da vida e da morte.

O segundo, no Cemitério da Consolação, na São Paulo em formação de meados do século XIX. A necrópole urbana, racionalmente organizada e cercada, com suas lápides individuais e sisudos monumentos mortuários, vira palco de um verdadeiro Carnaval! Respeitáveis senhores de cartola e casaca perdem a linha na companhia de esqueletos foliões. Bebem vinho sentados nas louças, fumam charutos, atracam-se lubricamente... $\mathrm{Na}$ inversão dos valores que a volta dos mortos promove, até uma ossada infantil participa da confusão. Não é à toa que a gravura foi alvo de críticas e motivo de indignação popular: a moral burguesa não brinca com seus mortos. $\mathrm{O}$ autor do desenho, ao se defender em artigo publicado no jornal de maior circulação da cidade, revelava conhecer bastante bem a referência que evocava - e as danças macabras, quem diria, viram assunto entre as rodas de intelectuais paulistas.

Mas, ao mesmo tempo que repercutem o imaginário macabro europeu, as duas obras são extremamente brasileiras. O poema, por seu linguajar regionalista, caro ao autor Bernardo Guimarães, se revela exemplar único, prova da aclimatação da tópica medieval aos trópicos. Mesclando a tradição macabra ao folclore, à fauna e à flora local e ainda utilizando vocábulos de origem indígena, africana e portuguesa, fica claro que a Orgia poderia acontecer em, praticamente, qualquer lugar do Brasil miscigenado. Tamanha identificação transformou seus versos em tradição oral.

Já a gravura tem por ambientação, justamente, a necrópole que abrigava as peripécias dos românticos estudantes da Faculdade de Direito. Foi no Cemitério da Consolação que tiveram lugar as lendárias pândegas da famigerada Sociedade Epicuréia. Como não relacionar a cena com as histórias dos jovens poetas acadêmicos 
das décadas de 1840 a 1860 ? A boêmia, a bebedeira e a morte caminhavam de mãos dadas com eles.

Assim, nesse percurso que parecia quase improvável à primeira vista, elaboramos uma pequena história do macabro que culmina no Romantismo brasileiro. Seus ecos, entretanto, ecoam por todo o século XIX e além dele. Como os mortos das danças macabras, o imaginário do cadáver putrefato retorna amiúde, expondo aos vivos suas próprias fragilidades. 


\section{Bibliografia}

AGGRAWAL, Anil. Necrophilia: Forensic and Medico-legal Aspects. Florida: Taylor \& Francis Group, 2011.

ANDRADA, Martim Francisco Ribeiro. Lágrimas e sorrisos: poesias. Rio de Janeiro: Typographia Brasiliense F.M. Ferreira, 1848.

ALMEIDA, Pires. A escola byroniana no Brasil. São Paulo: Conselho Estadual de Cultura, Comissão de Literatura, 1962.

ALVES, Antônio F. de Castro. Obra Completa. Rio de Janeiro: Nova Aguilar, 1997.

ALVES, Cilaine. Representações da arte popular: natureza e artifício no Romantismo brasileiro. Escritural - Écritures d'Amérique Latine. Université de Poitiers, n. 6, Décembre 2012.

ANJOS, Augusto dos. Eu e outras poesias. São Paulo: Martins Fontes, 1996.

APPLEFORD, Amy. The Dance of Death in London: John Carpenter, John Lydgate, and the Daunce of Poulys. In: Journal of Medieval and Early Modern Studies. 38:2, Duke University Press, 2008.

ARIÈS, Philippe e CHARTIER, Roger (orgs). História da vida privada 3: da Renascença ao Século das Luzes. São Paulo: Companhia das Letras, 1991.

ARIÈS, Philippe. História da morte no Ocidente. Rio de Janeiro: Ediouro, 2003.

ARIÈS, Philippe. O homem diante da morte. Volume I. Rio de Janeiro: Francisco Alves Ed., 1989.

ARIÈS, Philippe. O homem diante da morte. Volume II. Rio de Janeiro: Francisco Alves Ed., 1990.

ARISTÓTELES. Poética. Disponível em http://www.dominiopublico.gov.br. Último acesso em 02/04/2013.

ASSIS, Machado de. Obra completa. Volume III. Poesia, Crônica, Crítica, Miscelânea e Epistolário. Rio de Janeiro: José Aguilar, 1962.

AZEVEDO, Álvares. O Conde Lopo. Rio de Janeiro: Typ. G. Leuzinger \& Filhos, 1886.

AZEVEDO, Álvares. Obra Completa. Rio de Janeiro: Nova Aguilar, 2000.

AZEVEDO, Álvares. Noite na Taverna /Macário. Introdução de Edgar Cavalheiro. São Paulo: Martins, s/d.

AZEVEDO, Vicente de Paulo Vicente de. A vida amorosa dos poetas românticos. São Paulo: Conselho Estadual de Cultura, 1971.

BAKHTIN, Mikhail. A cultura popular na Idade Média e no Renascimento. Tradução de Yara Frateschi Vieira. São Paulo: Hucitec, 1987. 
BANDEIRA, Manuel. Antologia dos Poetas Brasileiros: Fase Romântica. Rio de Janeiro: Nova Fronteira, 1996.

BARBEY D'AUREVILLY, Jules. Léa. Collection électronique de la Bibliothèque Municipale de Lisieux, upload em 1996. Disponível em: http://www.bmlisieux.com/litterature/barbey/lea01.htm

BAROJA, Julio Caro. El Carnaval. Análisis historico-cultural. Madrid: Taurus, 1965.

BATAILLE, Georges. O erotismo. São Paulo: Arx, 2004.

BAUDELAIRE, Charles. Les fleurs du mal. Paris: Poulet-Malassis et De Broise Éd., 1857.

BAUDELAIRE, Charles. Les fleurs du mal. Seconde édition augmentée de trente-cinq poèmes nouveaux. Paris: Poulet-Malassis et De Broise Éd., 1861.

BÉGUIN, Albert. L'âme romantique et le rêve. Essai sur le romantisme allemand et la poésie française. Paris: José Corti, 1939.

BOCACCIO, Giovanni. Decamerão. São Paulo: Editora Abril, 1971, Col. Os Imortais da Literatura Universal.

BONIFÁCIO, José. Poesias. Organizado por Alfredo Bosi e Nilo Scalzo. São Paulo: Conselho Estadual de Cultura, Comissão de Literatura, 1962.

BOIME, Albert. Alfred Rethel's Counterrevolutionary Death Dance. In: The Art Bulletin. December 1991, Volume LXXIII, Number 4. Disponível em: http://www.albertboime.com/Articles/81.pdf

BOSI, Alfredo. História concisa da literatura brasileira. 2a edição. São Paulo: Cultrix, 1979.

BOREL, Pétrus. Champavert: contes immoreaux. Paris: Eugène Renduel ÉditeurLibraire, 1833.

BOREL, Pétrus. Madame Putiphar. Seconde édition, conforme pour le texte et les vignettes à l'édition de 1839. Paris: Librairie Léon Willem, 1877, Tome I.

BOREL, Pétrus. Madame Putiphar. Seconde édition, conforme pour le texte et les vignettes à l'édition de 1839. Paris: Librairie Léon Willem, 1878, Tome II.

BRIZEUX, Auguste. Oeuvres complètes. Paris: Michel Lévy Frères, 1860, Tomo 2.

BROCA, Brito. Românticos, Pré-Românticos, Ultra-Românticos - Vida literária e Romantiso Brasileiro. São Paulo: Polis, 1979.

BROCA, Brito. Naturalistas, Parnasianos e Decadistas. Vida literária do Realismo ao Pré-Modernismo. Campinas: Ed.UNICAMP, 1991.

BURKE, Edmund. Uma investigação filosófica sobre a origem de nossas idéias do sublime e do belo. Traudução de Enid Abreu Dobránszky. Campinas: Papirus, Editora da Universidade de Campinas, 1993. 
BURKE, Peter. Cultura popular na Idade Moderna. Tradução de Denise Bottmann. São Paulo: Companhia das Letras, 1999.

Cabrião: semanário humorístico editado por Ângelo Agostini, Américo Campos e Antônio Manuel dos Reis: 1866-1867. Introdução de Délio Freire dos Santos. 2a edição. São Paulo: Editora UNESP, Imprensa Oficial do Estado, 2000.

CALIXTO, Maria Leonor. A literatura "negra"ou "de terror"em Portugal nos séculos XVIII e XIX. Lisboa: Publicações da Faculdade de Letras da Universidade de Lisboa, 1956.

CAMARANI, Ana Luiza Silva. Intertextualidade e frenético em Han d'Islande. In: Lettres Françaises. Unesp, 2003, N. 5, p. 35-47.

CAMILO, Vagner. Risos entre pares: poesia e humor românticos. São Paulo: EDUSP/FAPESP, 1997.

CAMPAUX, Antoine-François. François Villon, sa vie et ses oeuvres. Paris: A. Durand, 1859. Disponível em:

http://gallica.bnf.fr/ark:/12148/bpt6k6323962m/f53.image.r=poise.langEN

CAMPOS, Haroldo de. A arte no horizonte do provável e outros ensaios. São Paulo: Perspectiva, 2010.

CANDIDO, Antonio. Formação da Literatura brasileira. Momentos decisivos.17501880. 12a edição. São Paulo: FAPESP, 2009.

CANDIDO, Antonio. Formação da Literatura brasileira. Momentos decisivos.17501880. Volume 2. 5a edição. São Paulo: Ed. Usp, 1975.

CANDIDO, Antonio. A eduação pela noite. 5a edição. Rio de Janeiro: Ouro sobre Azul, 2006.

CANDIDO, Antonio. $O$ discurso e a cidade. 3a ed. Riod e Janeiro: Ouro sobre Azul; São Paulo: Duas Cidades, 2004.

CARDINI, Franco. Magia, brujeria y superstición en el Occidente medieval. Barcelona: Edicions 62, 1982.

CAVALHEIRO, Edgard (org). O conto romântico. Rio de Janeiro: Civilização Brasileira, 1961.

CLARK, James M., The Dance of Death by Hans Holbein. Glasgow: The University Press, 1947.

CHAMPION, Pierre. Histoire poétique su quinzième siécle. Tomes I et II. Paris: Honoré Champion Editeur, 1923.

COELHO, José Maria Vaz Pinto. Poesias e romances do Dr. Bernardo Guimarães. Rio de Janeiro: Typ. Universal de Laemmert, 1885.

CORRÊA, Irineu Eduardo Jones. Bernardo Guimarães e o paraíso obsceno. A floresta enfeitiçada e os corpos da luxúria no romantismo. Tese de Doutorado, Programa de pósgraduação em Letras, UFRJ, 2006. 
CORVISIER, Andre. La Danse macabre de Meslay-le-Grenet, Chartres, Memoires de la Société Archéologique d'Eure et Loir, 1969.

CORVISIER, André. Les danses macabres. Collection Que sais-je?. Paris: Presses Universitaires de France, 1998.

CORVISIER, André. La représentation de la société dans les danses des morts du XVe au XVIIIe siècle. In: Revue d'Histoire Moderne et Contemporaine. Tome XVI, octobredécembre 1969, p. 489-539.

COURBIN, Alain (org). História do corpo. 3 volumes. Petrópolis: Vozes, 2008.

COUTINHO, Afrânio. A Literatura no Brasil. Era Romântica. $6^{\text {a }}$ ed. São Paulo: Global, 2002.

CRUZ, Dilermando. Bernardo Guimarães: perfil bio-biblio-litterário. Juiz de Fora: Casa Azul, 1911.

CUNHA, Cilaine Alves. O belo e o disforme. São Paulo: EDUSP/FAPESP, 1998.

CUNHA, Cilaine Alves. Representações da arte popular: natureza e artifício no Romantismo brasileiro. Escritural: Écritures d'Amérique latine. Revue du Centre de Recherches Latino-Américaines, Université de Poitiers, N. 6, Décembre 2012. Disponível em:

http://www.mshs.univ-poitiers.fr/crla/contenidos/ESCRITURAL/index.html

CUNHA, Fausto; DUTRA, Waltensir. Biografia crítica das letras mineiras. Rio de Janeiro: Instituto Nacional do Livro, 1959.

CUNHA, Maria Clementina, Ecos da folia. Uma história social do Carnaval carioca entre 1880 e 1920. São Paulo: Companhia das Letras, 2001.

DAMATTA, Roberto. Carnavais, malandros e heróis. Para uma sociologia do dilema brasileiro. Rio de Janeiro: Rocco, 1997.

Danse Macabre, paroles de Henri Cazalis, musique de Saint-Saëns. Paris: Enoch Père et Fils Éd., 1879.

Danse macabre. (fac-similés et traduction de Der doten dantz mit figuren, 1490). Introduction de René Wetzel. Traduction de Anna Sziráky. Maxéville: Presses Universitaires de France, Foundation Martin Bodmer, Collection Sources, 2011.

DEFOE, Daniel. Journal of the plague. London: Blackie \& Son, 19-?

DELUMEAU, Jean. História do medo no Ocidente. 1300-1800: uma cidade sitiada. São Paulo: Companhia das Letras, 2009.

DIAS, Antonio Gonçalves. Poesia e Prosa Completas. Organização de Alexei Bueno. Rio de Janeiro: Nova Aguilar, 1998.

DOUCE, Francis. The dance of death. London: William Pickering, 1833. 
DUBY, Georges. Ano 1000, ano 2000: na pista de nossos medos. Tradução: Eugenio Sila e Maria Regina Osório. São Paulo: Editora Unesp e Imprensa Oficial do Estado de São Paulo, 1999.

Du HAURON, Alcide Ducos. La danse macabre au XIXème siècle. 1864. Fac-símile disponível em https://play.google.com/store/books/details?id=O1suAAAAYAAJ

Encyclopèdie ou Dictionnaire raisonné des sciences, des arts et des métiers. Publié par M. Diderot et M. D'Alembert. Tome troisième. Paris: Briasson, David, Le Breton, Faulche, 1765.

Encyclopèdie ou Dictionnaire raisonné des sciences, des arts et des métiers. Publié par M. Diderot et M. D’Alembert. Tome dixième. Paris: Briasson, David, Le Breton, Faulche, 1765.

ESPRONCEDA, José de. El estudiante de Salamanca. Junta de Andalucía: Colección Averroes, Consejería de Educación y Ciencia, 2014. Disponível em: http://www.ucm.es/data/cont/docs/119-2014-02-19-

Espronceda.\%20ElEstudianteDeSalamanca.pdf

FLAUBERT, Gustave. Oeuvres de jeunesse. Paris: Éditions Gallimard, 2001.

FOUCAUD, Boris. L'ouevre d'Anatole France: à la recherche d'une philosophie du monde par l'écriture du Désir. Thèse de doctorat. Université d'Angers, juin 2001. Disponíevl em: http://www.borisfoucaud.com/these/

FRANCE, Anatole. Les poèmes dorés. Paris: Alphonse Lemerre Éditeur, 1873.

FRANCHETTI, Paulo. O riso romântico. Remate de Males: Revista do Departamento de Teoria Literária da Universidade Estadual de Campinas, n.7: 7-17, 1987.

FREIRE, Junqueira. Poesias Completas. Volumes I e II. Rio de Janeiro: Zélio Valverde, 1944, Coleção Poetas do Brasil.

FROIDMONT, Hélinand. Os versos da morte. Tradução: Heitor Megale. São Paulo: Ed. Imaginário, 1996.

GAUTIER, Théophile. La comédie de la mort. Paris, Desessart Éditeur, 1838.

GAUTIER, Théophile. Émaux et camées. (2e éd. augmentée). Paris, Poulet-Malassis et de Broise, 1858.

GAUTIER, Théophile. Mademoiselle de Maupin. Nouvelle Édition. Paris: Charpentier et Cie, 1876.

GAUTIER, Théophile. Les Jeunes-France, romans goguenards. Suivis de contes humoristiques. Paris: G. Charpentier Éditeur, 1878.

GINZBURG, Carlo. História noturna. Decifrando o sabá. São Paulo: Companhia das Letras, 2012.

GLIXELLI, Stefan. Le cinq poèmes des trois morts et des trois vifs. Paris: Librairie Ancienne Honoré Champion Éditeurs, 1914.

GOETHE, Johann Wolfgang von. Voyages en Suisse et en Italie.Paris: Hachette, 1862. 
GOETHE, Johann Wolfgang von. The Poems of Goethe - Translated in the Original Metres by Edgar Alfred Bowring. London, 1874. Disponível em http://archive.org/stream/thepoemsofgoethe01287gut/tpgth10.txt

GOETHE, Johann Wolfgang von. Doutrina das cores. Tradução de Marco Giannotti. São Paulo: Nova Alexandria, 1993.

GOMES, Ednaldo Cândido Moreira. Sutilezas e mordacidades na poética de Bernardo Guimarães. Dissertação de Mestrado. Programa de pós-graduação em Letras da Pontifícia Universidade Católica de Minas Gerais, Belo Horizonte, 2007.

GOMES, Álvaro Cardoso e VECHI, Carlos Alberto. A estética romântica. Textos doutrinários comentados. São Paulo: Atlas, 1992.

GRAHAM, Mary. Journal of a voyage to Brazil and residence there during part of the years 1821, 1822, 1823. London: Longman, Hurst, Reers, Orme, Brown and Green, 1824.

GRIECO, Agrippino. Evolução da poesia brasileira. Rio de Janeiro: Ariel, 1932.

GUIMARÃES, Bernardo. Folhas de Outono. Rio de Janeiro: Garnier, 1883.

GUIMARÃES, Bernardo. Poesias completas. Rio de Janeiro: Ministério da Educação e Cultura, Instituto Nacional do Livro, 1959.

GUIMARÃES, Bernardo. Poesia erótica e satírica. Prefácio, organização e notas de Duda Machado. Rio de Janeiro: Imago, 1992.

GUIMARÃES, Bernardo. Äureliano Lessa”. Prefácio in: LESSA, Aureliano José. Poesias pósthumas do Dr. Aureliano José Lessa. Editadas por seu irmão Francisco José Pedro Lessa. Rio de Janeiro: Typ. da Luz, 1873, pp. V-XVIII.

GUIMARAENS, Alphonsus de. Obra Completa. Rio de Janeiro: José Aguilar, 1960.

GUINSBURG, Jacó (org). O Romantismo. São Paulo: Perspectiva, 1993.

HADDAD, Jamil Almansur. Álvares de Azevedo, a Maçonaria e a Dança. São Paulo: Conselho Estadual de Cultura, Comissão de Literatura, 1960.

HADDAD, Jamil Almansur. Introdução a Bernardo Guimarães. Separata da Revista do Arquivo Municipal. Vol. CXLII. São Paulo: Departamento de Cultura, Divisão do Arquivo Histórico, 1952.

HEERS, Jacques. Festas de Loucos e Carnavais. Tradução de Carlos Porto. Lisboa: Dom Quixote, 1987.

HELMREICH, Christian. La traduction des "Souffrances du jeune Werther" en France (1776-1850). Contribution à une histoire des transferts franco-allemands. In: Revue germanique internationale [En ligne], 12 | 1999, p. 179-193. Disponível em: http://rgi.revues.org/753

HEINE, Henri. De la France. Nouvelle Édition. Paris: Michel Lévy Frères Editeurs, 1873. 
HOBSBAWM, Eric. A era das revoluções. Europa 1789-1848. Rio de Janeiro: Paz e Terra, 2006.

HOFFBAUER, Theodor Josef Hubert. Paris à travers les âges. Paris: Firmin-Didot, 1885 .

HOLANDA, Sérgio Buarque de. Cobra de vidro. São Paulo: Perspectiva, 1978.

HOLBEIN, Hans. Simulachres \& histoires facées de la Mort. Lyon: Melchior e t Gaspar Trechesel, 1538.

HOWARTH, Glennys e LEAMAN, Oliver. Enciclopédia da Morte e da Arte de Morrer. Rio de Mouros: Printer Portuguesa, 2004.

HUGO, Victor. William Shakespeare. Paris: Albin Michel, 1937.

HUGO, Victor. La légende des siècles. Nouvelle série. Paris: Calmann Lévy Éditeur,1877, Tome II.

HUGO, Victor. Do grotesco e do sublime. Tradução do "Prefácio de Cromwell". Tradução e notas de Celia Berretini. São Paulo: Perspectiva, 1988.

HUGO, Victor. O corcunda de Notre Dame. Rio de Janeiro: Zahar, 2013.

HUIZINGA, Johan. O outono da Idade Média. Estudo sobre as formas de vida e de pensamento dos séculos XIV e XV na França e nos Países Baixos. São Paulo: Cosac Naify, 2010.

HURTADO, Haydée Bermejo y CVITANOVIC, Dinko. Danza General de la Muerte. Bahía Blanca: Cuadernos del Sur, 1966.

INFANTES, Víctor. Las danzas de la muerte. Génesis y desarrollo de un género medieval (siglos XIII-XVII). Salamanca: Ediciones Universidad de Salamanca, 1997.

JANIN, Jules. L'âne mort et la femme guillotinée. Paris: Adolphe Delahays Éditeur, 1861.

Journal d'un Bourgeois de Paris, 1405-1449. Publié d'après les manuscrits de Rome et de Paris par Alexandre Tuetey. Paris: H. Champion, 1881.

KANT, Emmanuel. Observações sobre os sentimento do belo e do sublime; Ensaio sobre as doenças mentais. Tradução de Vinícius Figueiredo. Campinas: Papirus, 1993.

KANT, Immanuel. Duas introduções à Crítica do Juízo. São Paulo: Iluminuras, 1995.

KANT, Immanuel. Crítica da Faculdade do Juízo. Tradução de Valério Rohden e António Marques. 3a edição. Rio de Janeiro: Forense Universitária, 2012.

KASTNER, Georges. Les Danses des Morts. Dissertations et recherches historique, philosophiques, littéraires et musicales sur les divers monuments de ce genre qui existent ou qui ont existé tant en France qu'à l'étranger.Accompangnés de La Danse Macabre. Paris: Brandus e Cie Éditeurs, 1852.

KAYSER, Wolfgang. O grotesco. São Paulo: Perspectiva, 1986. 
KRISTEVA, Julia. Pouvoirs de l'horreur. Essai sur l'abjection. Paris: Seuil, Collection Points 152, 1983.

LACROIX, Paul. La Danse Macabre. Histoire fantastique du quinzième siècle. Paris: Eugène-Renduel Éditeur, 1832.

LANGLOIS, E.H. Essai historique, philosphe et pittoresque sur les Danses des Morts. Rouen: A. Lebrument Librairie, 1852.

LARMAND, Léon. Les poètes de la mort. Anthologie de poèsies de la mort du XVe siècle a nos jours. Paris: Louis-Michaud, 1910.

LEWIS, Mathew Gregory. The monk. E-book disponível em http://www.gutenberg.org/files/601/601-h/601-h.htm Postado pelo Project Gutenberg, em 2008.

LIMA, Israel Souza. Biobibliografia dos patronos, v. 3: Bernardo Guimarães e Casimiro de Abreu. Rio de Janeiro: Academia Brasileira de Letras, 2000.

LIMA, Luiz Costa. Pensando nos trópicos. (Dispersa Demanda II). Rio de Janeiro: Rocco, 1991.

LOBATO, Monteiro. Cidades Mortas. São Paulo: Brasiliense, 1986.

LOBO, Luiza (org). Teorias poéticas do Romantismo. Porto Alegre: Mercado Aberto, Coleção Novas Perspectivas, 1987.

LONGINO. Do sublime. In: ARISTÓTELES, HORÁCIO, LONGINO. A poética clássica. São Paulo: Cultrix/ Edusp, 1981, p. 70-114.

LORRAIN, Jean. Histoires de masques. Paris: Societé d'Éditions Littéraires et Artistiques, 1900.

LÖWY, Michel. (et alli). Revolta e melancolia: o Romantismo na contramão da modernidade. Tradução de Guilherme João de F. Teixeira. Petrópolis: Vozes, 1995.

LOYN, Henry R. (org). Dicionário da Idade Média. Tradução de Alvaro Cabral. Rio de Janeiro: Jorge Zahar, 1997.

LUFT, Celso Pedro. Dicionário de Literatura Portuguesa e Brasileira. Porto Alegre: Editora Globo, 1967.

MACHADO, Antonio de Alcântara. Cavaquinho e saxofone. (Solos) 1926-1935. Rio de Janeiro: Livraria José Olympio, 1940.

MACHADO, Duda. Bernardo Guimarães: a exceção pelo riso. Revista USP, São Paulo, n. 74, p. 174-187, junho/agosto 2007.

MAGALHÃES, Basílio de. Bernardo Guimarães (esboço crítico). Rio de Janeiro: Typographia do Annuário do Brasil, 1926.

MAGALHÃES, Domingos José Gonçalves de. Cânticos fúnebres. Rio de Janeiro: Livraria de B.L.Garnier, 1864. 
MÂLE, Émile. L'art religieux de la fin du Moyen Age en France. Étude sur l'iconographie du Moyen Age et sur ses sources d'inspiration. 5e édition. Paris: Librairie Armand Colin Ed., 1949.

MARTINS, Wilson. História da inteligência brasileira. Vol. II (1794-1855). São Paulo: Cultrix, 1977.

MATURIN, Charles Robert. Melmoth, the wanderer. E-book disponível em http://ebooks.adelaide.edu.au/m/maturin/charles/melmoth_the_wanderer/index.html Postado pela University of Adelaide Library, em 2005.

MATURIN, Charles Robert. Bertram, ou Le Chateau de St. Aldobrand, tragédie en cinq actes. Traduite librement de l'anglois par Mm. Taylor et Ch. Nodier. Paris: Gide Fils Libraire, 1821.

MENDONÇA, Lucio. Murmúrios e clamores. Poesias Completas. Rio de Janeiro: H. Garnier, 1962.

MERQUIOR, José Guilherme. De Anchieta a Euclides. Breve História da Literatura Brasileira. Rio de Janeiro: José Olympio, 1977.

MÉTAYER, Christine. Un espace de vie: les charniers du cimetière des SS. Innocents à Paris, sous l'Ancien Régime. Journal of the Canadian Historical Association/Revue de la Societé historique du Canada, vol. 4, n. 1, 1993, p. 183-206. Disponível em http://www.erudit.org/revue/jcha/1993/v4/n1/031062ar.pdf

MEZAN, Renato. "A medusa e o telescópio ou Vergasse 19". In: NOVAES, Adauto (org.) O olhar. São Paulo: Companhia das Letras, 1988.

MINOIS, Georges. História do riso e do escárnio. Tradução de Maria Helena Assumpção. São Paulo: Editora Unesp, 2003.

MOLINIER, Auguste. Inventaire sommaire de la collection Joly de Fleury. Paris: A. Picard, 1881.

MONTEIRO, Débora Paiva. O mais querido "fora da lei": um estudo sobre o entrudo na cidade do Rio de Janeiro. (1889-1910). Anais do XIV Encontro Regional da Anpuh. Rio de Janeiro, Unirio, 19 a 23 de julho de 2010.

MOISÉS, Massaud. História da Literatutra Brasileira. São Paulo: Cultrix, 1985.

MORAES, Eliane Robert. Sade: a felicidade libertina. Rio de Janeiro: Imago, 1994.

MORAIS FILHO, Mello. Parnaso brazileiro. Século XVI-XIX. Rio de Janeiro: Garnier, 1885.

MORIN, Edgar. O homem e a morte. Tradução: Cleone Rodrigues. Rio de Janeiro: Imago, 1997.

NERVAL, Gérard de. Le rêve et la vie. Paris: Victor Lecou Ed., 1855. 
NOVAES, Adauto (org). O homem-máquina. A ciência manipula o corpo. São Paulo: companhia das Letras, 2003.

NOVAES, Adauto (org). O desejo. São Paulo: Companhia das Letras, 1990.

NOVAIS, Fernando (dir) e ALENCASTRO, Luis Felipe (org). História da vida privada no Brasil 2. Império: a corte e a modernidade nacional. São Paulo: Companhia das Letras, 1997.

OOSTERWIJK, Sophia. "Fro Paris to Inglond"? The danse macabre in text and image in late-medieval England. Doctoral thesis. Department of English Language and Culture, Faculty of Humanities, Leiden University, 2009. Disponível em https://openaccess.leidenuniv.nl/handle/1887/13873

PAQUOT, Thierry. Le sentiment de la nuit urbaine aux XIXe et XXe siècles. In: Les Annales de la Recherche Urbaine, n. 87, Septembre 2000, p. 6-14. Disponível em: http://www.annalesdelarechercheurbaine.fr/le-sentiment-de-la-nuit-urbaine-a184.html

PAZ, Octavio. Os filhos do barro. Do Romantismo à vanguarda. Tradução de Olga Savary. Rio de Janeiro: Nova Fronteira, 1984.

PERROT, Michelle (org.) História da vida privada 4: da Revolução Francesa à Primeira Guerra. Tradução: Denise Bottman e Bernardo Joffily. São Paulo: Companhia das Letras, 1991.

PIRENNE, Henri. História econômica e social da Idade Média. São Paulo: Mestre Jou, 1968.

PÔRTO, Ângela. Representações sociais da tuberculose: estigma e preconceito. Revista da Saúde Pública, 2007, 41 (Supl. 1): 43-49.

PRAZ, Mario. A carne, a morte e o diabo na literatura romântica. Tradução de Philadelpho Menezes. Campinas: Editora UNICAMP, 1996.

RABELAIS, François. Gargantua et Pantagruel. Texte transcrit et annoté par Henri Clouzot. Tome I et II. Paris: Bibliothèque Larousse, s/d.

RABELAIS, François. Gargantua. Tradução de Aristides Lobo. São Paulo: Hucitec, 1986.

RABELAIS, François. Pantagruel. Préface de Michelet. Paris: Gallimard, 1964.

RABELO, Laurindo. Poesias Completas. Edição e prefácio de Attilio Milano. Rio de Janeiro: Zélio Valverde, s/d, Coleção Grandes Poetas do Brasil.

RADCLIFFE, Ann. On the Supernatural in Poetry. In New Monthly Magazine. Volume $16, \mathrm{n}^{\circ} 1$ (1826), pp. 145-152.

RAMOS, Péricles Eugênio da Silva. Poesia Romântica: Antologia. São Paulo: Melhoramentos, 1965.

RAMOS, Péricles Eugênio da Silva. Do Barroco ao Modernismo. Estudos de poesia brasileira. Rio de Janeiro: Livros Técnicos e Científicos, 1979. 
ROMERO, Sílvio. História da Literatura Brasileira. Tomo Terceiro: Transição e Romantismo. 6a edição. Rio de Janeiro: José Olympio, 1960.

ROSEN, Charles. Poetas românticos, críticos e outros loucos. São Paulo: Ateliê Editorial, 2004.

ROUDINESCO, Elisabeth. A parte obscura de nós mesmos. Uma história dos perversos. Rio de janeiro: Zahar, 2008.

RYTTING, Jenny Rebecca. A Disputacioun Betwyx pe Body and Wormes: A Translation. In: Comitatus: A Journal of Medieval and Renaissance Studies, 31(1). UCLA, 2000. Disponível em: http://escholarship.org/uc/item/0c04p0xq. Último acesso em: 09/07/2012.

SANTO AGOSTINHO. Confissões. Disponível em http://www.dominiopublico.gov.br. Último acesso em 02/04/2013.

SANTOS, Carlos José. Bernardo Guimarães na intimidade. Belo Horizonte: Typ. Antunes, 1928.

SAUGNIEUX, Joël. Les danses macabres de France et d'Espagne et leurs prolongements littéraires. Paris: Société d'Édition “Les Belles Lettres”, 1972.

SCOTT, Walter. Poetical works. London: MacMillan and Co, 1869.

SCHAEFER, Sérgio. Dialogismo, polifonia e carnavalização em Dostoiévski. In: Bakhtiniana, Revista de Estudos do Discurso [online]. 2011, vol. 6, n. 1, pp 194-209.

SCHILLER, Friedrich. Do sublime ao trágico. Organização de Pedro Sussekind. Belo Horizonte: Autêntica, 2011.

SCHILLER, Friedrich. A educação estética do homem numa série de cartas. Tradução de Roberto Schwarz e Márcio Suzuki. São Paulo Iluminuras, 1995.

SCHMITT, Jean-Claude. Os vivos e os mortos na sociedade medieval. São Paulo: Companhia das Letras, 1999.

SEBE, José Carlos. Carnaval, Carnavais. São Paulo: Ática, 1986.

SELIGMANN-SILVA, Márcio. O local da diferença. Ensaios sobre memória, arte, literatura e tradução. São Paulo: Editora 34, 2005.

SODRÉ, Nelson Werneck. História da Literatura Brasileira. 8a ed. Rio de Janeiro: Bertrand, 1988.

SOLÁ-SOLÉ, Josep M. La Dança General de la Muerte. Edición crítica, analíticocuantitativa. Barcelona: Puvill Editor, 1981.

SOUSA, João da Cruz. Poesias. Introdução e notas de Nestor Vitor. Rio de Janeiro: Edição do Annuario do Brasil, 1923.

SOUZA, Laura de Mello e. Inferno Atlântico: demonologia e colonização: séculos XVIXVIII. São Paulo: Companhia das Letras, 1993. 
STEGEMEIER, Henri. Goethe and the Totentanz. The Journal of English and Germanic Philology. University of Illinois Press, Vol. 48, No. 4, Goethe Bicentennial Issue 1749-1949 (Oct, 1949), pp. 582-587. Disponível em: http://www.jstor.org/stable/27715033

STENDHAL, M. Le rouge et le noir: chronique du XIXe siècle. Tome I et II. Paris: A. Lavavasseur, 1831.

SÜSSEKIND, Flora. Papéis colados. Rio de Janeiro: Ed. UFRJ, 1993.

TENENTI, Alberto. Il senso della morte e l'amore della vita nel Rinascimento (Francia e Italia). Giulio Enaudi Editore, 1957.

TENENTI, Alberto. La vie et la mort à travers l'art du XVe siècle. Paris: Librairie Armand Colin Ed., Cahiers des Annales 8, 1952.

TORRES-MARCHAL. A lenda do Tatuturema. Eutomia. Revista Online de Literatura e Linguística do Departamento de Letras da Universidade Federal de Pernambuco. Ano II, N. 2 - Dezembro de 2009.

TUNISON, Joseph S. Dramatic traditions of the dark ages. Chicago: The University of Chicago Press, 1907.

UTZINGER, Hélène et Bertrand. Itinéraires des Danses macabres. Chartres: Éditions J.M. Garnier, 1996.

VARELLA, Fagundes. Obras Completas. Rio de Janeiro: Garnier, 1919.

VASCONCELOS, Sandra Guardini. Dez lições sobre o romance inglês do século XVIII. São Paulo: Boitempo, 2002.

VEUILLOT, Louis. Les pèlerinages de Suisse. Tours: A. Mame et Cie, cinquième édition, 1845.

VERÍSSIMO, José. História da Literatura Brasileira. De Bento Teixeira a Machado de Assis. 5a edição. Rio de Janeiro: José Olympio, 1969.

VERÍSSIMO, José. Estudos de Literatura Brasileira: 2 a série. Belo Horizonte: Itatiaia; São Paulo: Ed. Usp, 1977.

VERLAINE, Paul. Poèmes saturniens. Paris: Alph. Lemerre Éditeur, 1867.

Vifs nous sommes... morts nous serons: la rencontre des trois morts et des trois vifs dans la peinture murale en France. Groupe de recherches sur les peintures murales. Vendôme: Éditions du Cherche-Lune, 2001.

VIGARELLO, Georges. O limpo e o sujo. Uma história da higiene corporal. Tradução: Mônica Stahel. São Paulo: Martins Fontes, 2002.

VOVELLE, Michel. A história dos homens no espelho da morte. In: BRAET, Herman e VERBEKE, Werner (orgs.). A morte na Idade Média. São Paulo: Ed.USP, 1996.

VOVELLE, Michel. La Mort et l'Occident de 1300 à nos jours. Paris: Gallimard, 1983. 
WARREN, Florence. The Dance of Death. Edited from MSS. Ellesmere 26/A.13 and B.M. Landsdowne 699, Collated with the other extant MSS. Londres: Oxford University Press, 1931.

WARTON, Thomas. History of English Poetry - From the eleventh to the seventeenth century. London, Vincent Brooks, 1778-1781. Disponível em https://archive.org/stream/historyofenglis02wartuoft/historyofenglis02wartuoft_djvu.txt

WEISKEL, Thomas. $O$ sublime romântico. Estudos sobre a estrutura e psicologia da transcendência. Tradução de Patrícia Flores da Cunha. Rio de Janeiro: Imago, 1994.

WILLER, Claudio. Um obscuro encanto: gnose, gnosticismo e a poesia moderna. Rio de Janeiro: Civilização Brasileira, 2010. 


\section{Índice de imagens}

\section{Introdução}

Figura 1. O cemitério da Consolação no Dia de Finados.

Fonte : Cabrião: semanário humorístico, 2000.

\section{Capítulo 1}

Figura 1: Efíge de François de La Sarra, 1380-1400.

Capela de Saint-Antoine, Vaud, Suiça.

Fonte: www.izymanager.com/chateaulasarraz/.

Figura 2: Efígie de Guillaume de Harcigny. 1393.

Museu de Laon, França.

Fonte: fr.wikipedia.org/wiki/Guillaume_de_Harcigny

Figura 3: Efígie de Jean Lagrange, ca. 1402.

Musée du Petit Palais d'Avignon, França.

Fonte: Fonte: www.petit-palais.org/musee/fr/

Figura 4: $O$ encontro dos três mortos com os três vivos.

Anônimo, Século XV. Afresco do convento beneditino de Subiaco, Itália.

Fonte: http://www.benedettini-subiaco.it/monastero_sanbenedetto.asp?rid=38

Figura 5: Le cimetière et l'église des Saints-Innocents.

Anônimo, c. 1570. Musée Carnavelet em Paris, França.

Fonte:www.carnavalet.paris.fr/fr/collections/le-cimetiere-et-l-eglise-des-saints-

innocents.

Figura 6: Galeria do cemitério de Saints-Innocents.

T. J. H. Hoffbauer, 1885.

Fonte: HOFFBAUER, 1885, p. 377.

Figura 7: Primeiro painel da dança macabra de La Chaise-Dieu.

Meados do século XV. Abadia de La Chaise-Dieu, Alto Loire, França.

Fonte: arquivo pessoal.

Figura 8: Detalhe do terceiro painel da dança macabra de La Chaise-Dieu.

Meados do século XV. Abadia de La Chaise-Dieu, Alto Loire, França.

Fonte: arquivo pessoal.

Figura 9: Afrescos no interior da igreja de Meslay-le-Grenet, França.

Anônimo, final do século XV.

Fonte: arquivo pessoal.

Figura 10: detalhe da dança macabra de Meslay-le-Grenet.

Anônimo, final do século XV. 
Fonte: arquivo pessoal.

Figura 11: Os cadáveres-músicos.

Dança macabra de Guyot Marchand, 1485.

Fonte: gallica.bnf.fr

Figura 12: O Papa e o Imperador.

Dança macabra de Guyot Marchand, 1485.

Fonte: gallica.bnf.fr

Figura 13: O monge, o usurário e o pobre.

Dança macabra de Guyot Marchand, 1485.

Fonte: gallica.bnf.fr

Figura 14: Página da dança macabra de Antoine Vérard, 1491.

Fonte: http://www.dodedans.com/

Figura 15: Página da dança macabra de Antoine Vérard, 1491.

Fonte: http://www.dodedans.com/

Figura 16: Página da dança macabra de Antoine Vérard, 1491.

Fonte: http://www.dodedans.com/

Figura 17: Hieronymus Bosch, A morte do avarento (1490-1500).

National Gallery of Art, Washington.

Fonte: en.wikipedia.org/wiki/Death_and_the_Miser

Figuras 18 e 19: O dia do Juízo.

Livro de horas da família Rohan, 1410-1415.

Fonte:http://commons.wikimedia.org/wiki/Category:Grandes_Heures_de_Rohan_-

_BNF,_Lat._9471

Figura 19: O ofício dos mortos.

Livro de horas da família Rohan, 1410-1415.

Fonte:http://commons.wikimedia.org/wiki/Category:Grandes_Heures_de_Rohan_-

_BNF,_Lat._9471

Figura 20: Triunfo da Morte no Palazzo Abbatelli, em Palermo, Itália.

Anônimo, século XV.

Fonte: http://it.wikipedia.org/wiki/File:Palermo-trionfo-della-morte-bjs.jpg

Figura 21: Ilustrações do manuscrito Disputacioun Betwyx the Body and Wormes.

Anônimo, ca. 1435-1440.

Fonte: www.wga.hu

\section{Capítulo 3}

Figura 1: Gravura da dança macabra de Holbein: A Morte e a Rainha.

Hans Holbein, Simulachres \& histoires facées de la Mort, 1523-1526

Fonte: HOLBEIN, 1538

Figura 2: Gravura da dança macabra de Holbein: A Morte e o cavaleiro.

Hans Holbein, Simulachres \& histoires facées de la Mort, 1523-1526

Fonte: HOLBEIN, 1538 
Figura 3: Página inteira da dança macabra de Holbein. A Morte e os recém-casados.

Hans Holbein, Simulachres \& histoires facées de la Mort, 1523-1526

Fonte: HOLBEIN, 1538

Figura 4: Gravura da dança macabra de Holbein: A Morte e a criança.

Hans Holbein, Simulachres \& histoires facées de la Mort, 1523-1526

Fonte: HOLBEIN, 1538

Figura 5: Frontispício da The English Dance of Death

Thomas Rowlandson, 1814.

Fonte: http://www.bonhams.com

Figura 6: The Dance of Death Modernised

G. M. Woodward, 1808.

Fonte: images. library.yale.edu

Figura 7: Todtentanz, quarta prancha

Alfred Rethel, 1848

Fonte: BOIME, 1991.

\section{Capítulo 4}

Figura 1: A Morte no baile de Carnaval, The English Dance of Death, Thomas Rowlandson, 1814.

Fonte: www.augustana.edu

Figura 2: Os resultados do Entrudo

Frederico Guilherme Briggs, 1840.

Fonte: CUNHA, Ecos da folia, 2001, Caderno de Ilustrações.

Figura 3: Ilustração “O Carnaval de 1876” para a Revista Ilustrada

Angelo Agostini, 1876.

Fonte: NOVAIS e ALENCASTRO, História da vida privada no Brasil, 1997, p. 69. 188

\section{Capítulo 5}

Figura 1. Gravura no frontispício da Dotendantz

Anônimo, ca. 1490.

Fonte: Danse macabre, 2011.

Figura 2: Pieter Bruegel, Triunfo da Morte (detalhe). ca 1562

Museo del Prado, Madrid, Espanha.

Fonte: en.wikipedia.ork/wiki/The_Triumph_of_Death 